\title{
Application of Garnet in Sedimentary Provenance Analysis
}

\author{
Dissertation \\ zur Erlangung des mathematisch-naturwissenschaftlichen Doktorgrades \\ „Doctor rerum naturalium“ \\ der Georg-August-Universität Göttingen \\ im Promotionsprogramm Geowissenschaften / Geographie \\ der Georg-August-University School of Science (GAUSS)
}

vorgelegt von

\author{
Anne Krippner \\ aus Herdecke \\ Göttingen 2015
}




\section{Betreuungsausschuss}

Prof. Dr. Hilmar von Eynatten, Abteilung Sedimentologie und Umweltgeologie, GZG Prof. Dr. Gerhard Wörner, Abteilung Geochemie, GZG

\section{$\underline{\text { Mitglieder der Prüfungskommission }}$}

Referent: Prof. Dr. Hilmar von Eynatten, Abteilung Sedimentologie und Umweltgeologie, GZG

Korreferent: Prof. Dr. Gerhard Wörner, Abteilung Geochemie, GZG

2. Korreferent: Dr. Guido Meinhold, Abteilung Sedimentologie und Umweltgeologie, GZG

\section{Weitere Mitglieder der Prüfungskommission}

Dr. István Dunkl

Prof. Dr. Jonas Kley

Prof. Dr. Bent T. Hansen

Tag der mündlichen Prüfung: 02.07.2015 
Hiermit erkläre ich an Eides statt, die vorliegende Arbeit selbstständig angefertigt zu haben und dabei keine anderen als die von mir angegebenen Quellen und Hilfsmittel benutzt zu haben. Ferner erkläre ich, dass ich nicht anderweitig versucht habe, eine Dissertation einzureichen.

Göttingen, 01 Juni 2015 



\section{TABLE OF CONTENTS}

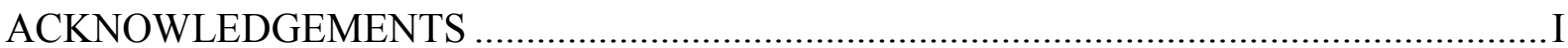

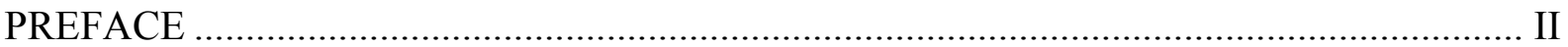

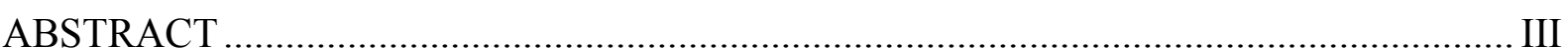

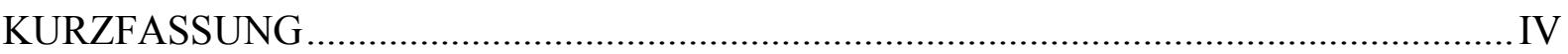

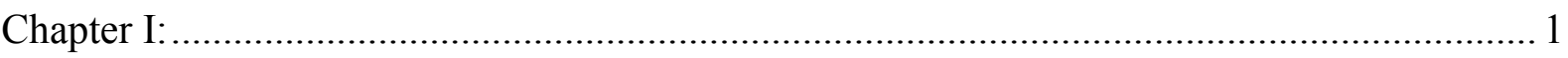

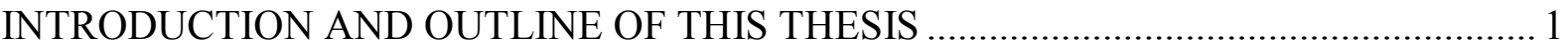

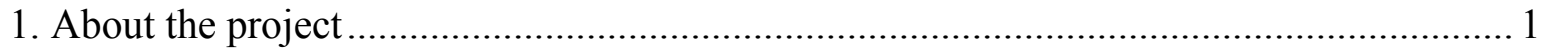

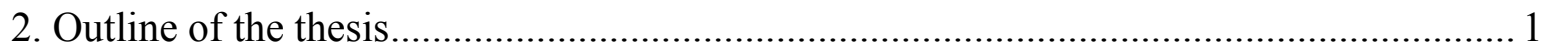

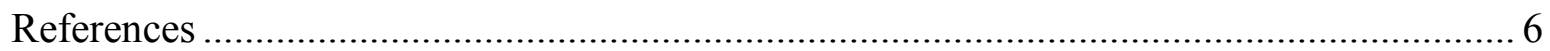

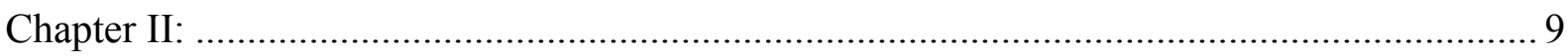

Manuscript I: Evaluation of garnet discrimination diagrams using geochemical data of garnets

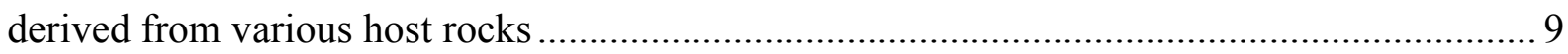

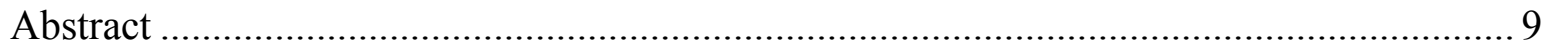

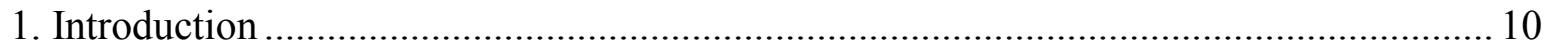

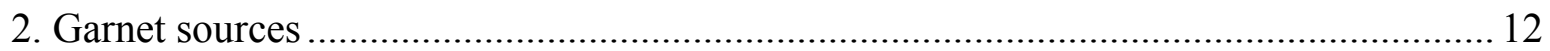

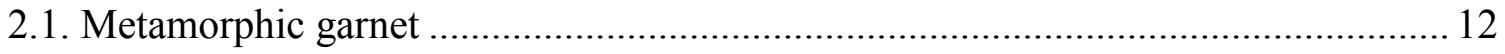

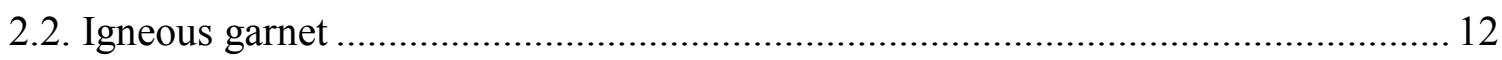

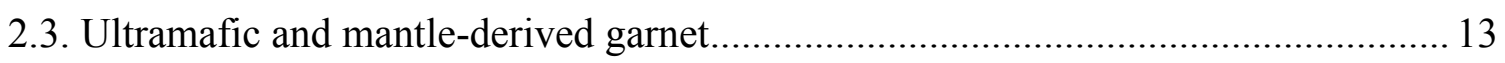

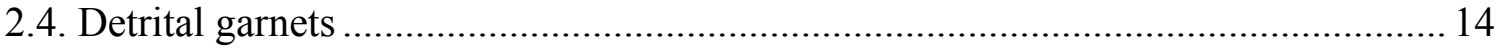

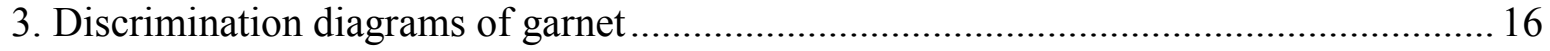

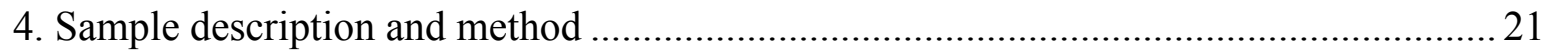

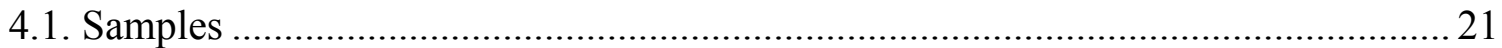

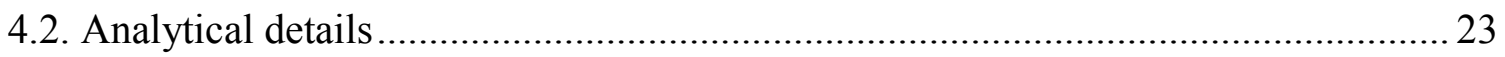

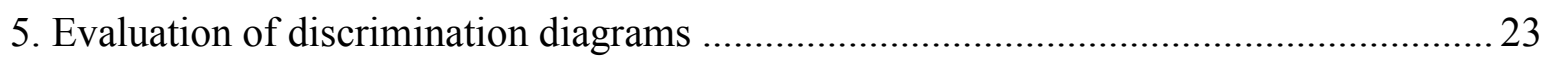

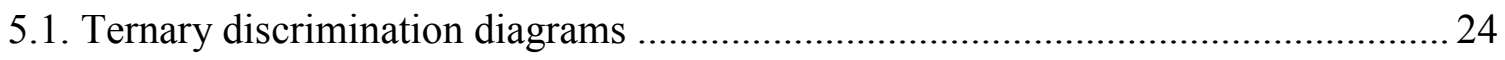

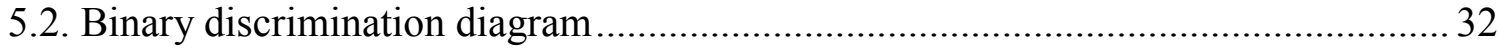

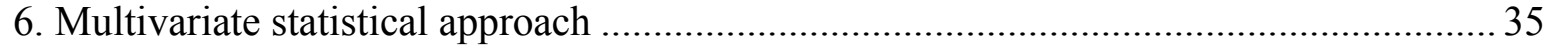

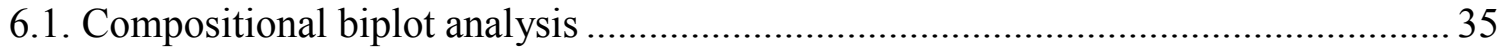

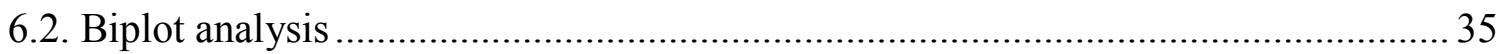

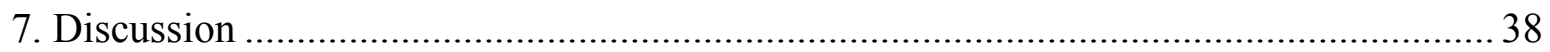

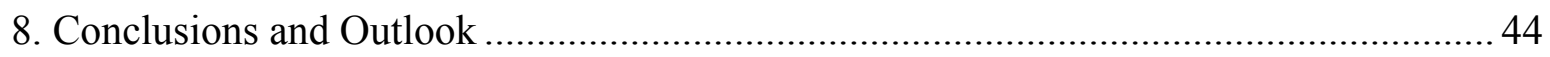

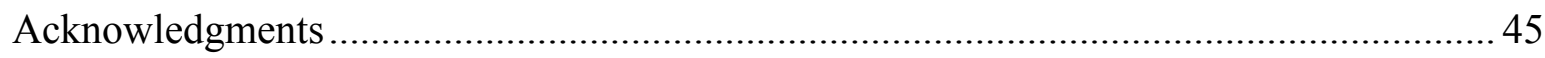


References

Chapter III:

Manuscript II: Grain-size dependence of garnet composition revealed by provenance signatures of modern stream sediments from the western Hohe Tauern (Austria). .55

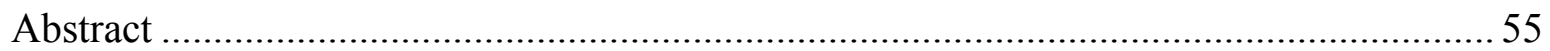

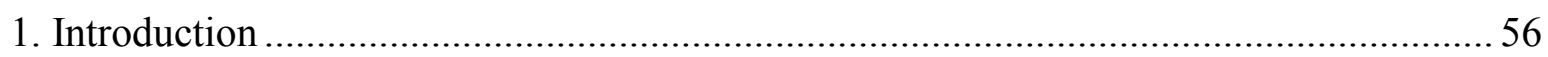

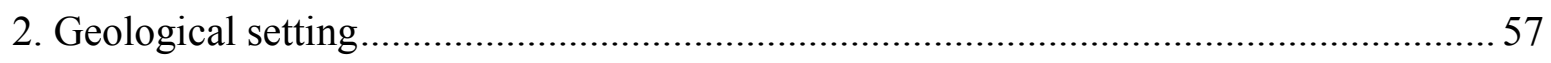

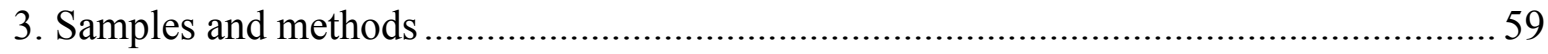

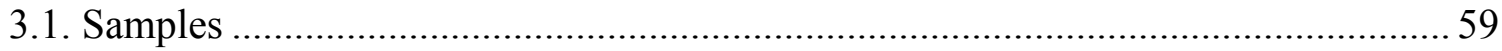

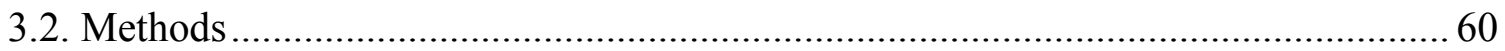

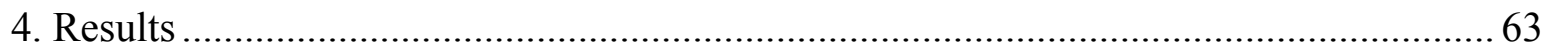

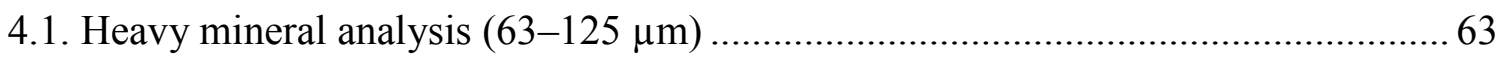

4.2. Heavy mineral analysis vs. grain-size fraction (samples A2-5, A2-8, A2-1, A2-4

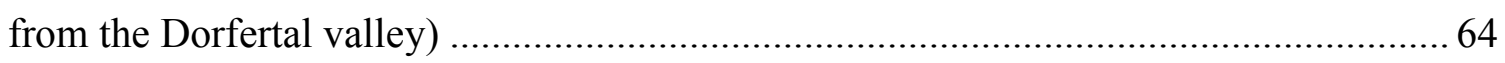

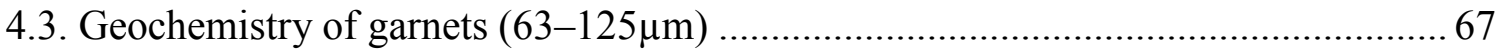

4.4. Geochemistry of garnets from different grain-size fractions from the Dorfertal valley .73

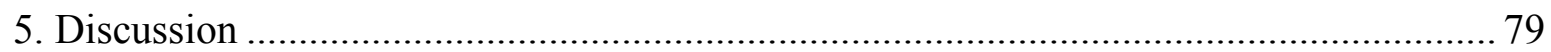

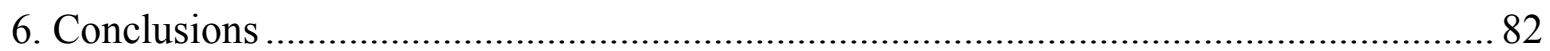

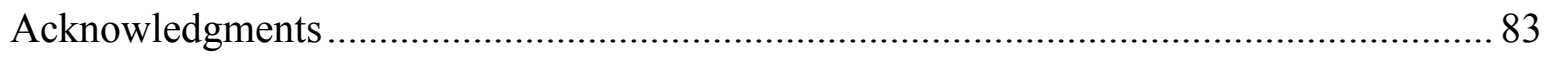

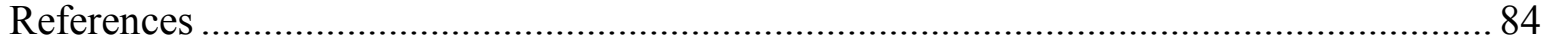

Chapter IV:

Manuscript III: Heavy minerals and garnet geochemistry of stream sediments and hardrocks from the Almklovdalen area, Western Gneiss Region, SW Norway: implications for

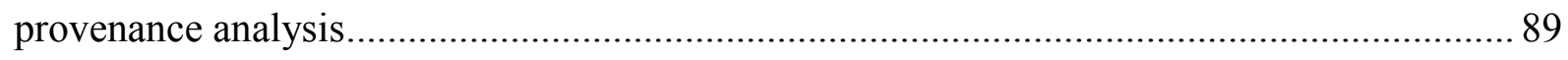

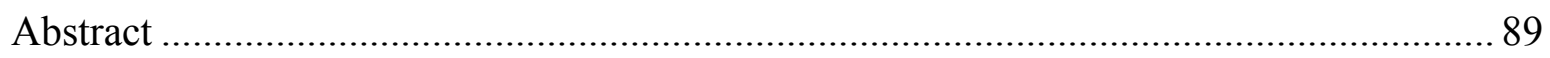

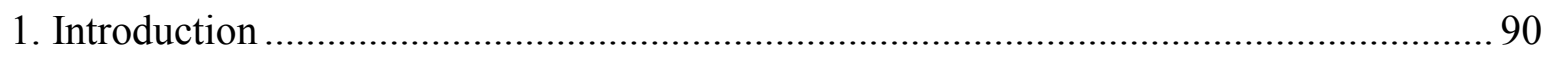

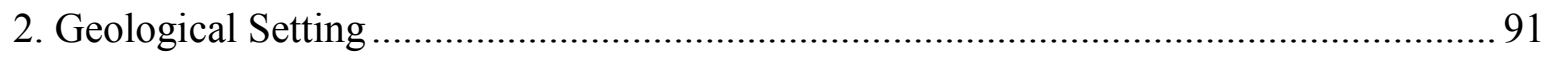

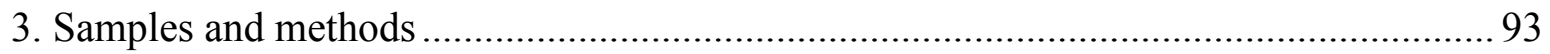

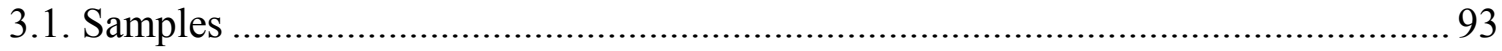

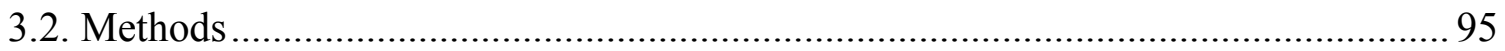

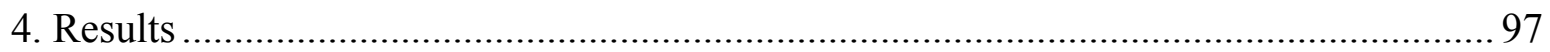

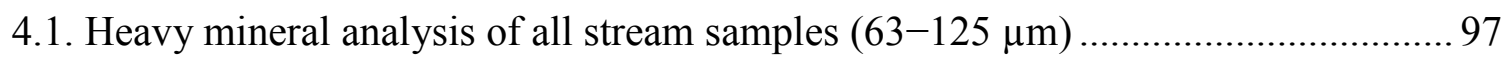


4.2. Heavy mineral analysis of sample AK-N19-3 (63-125 $\mu \mathrm{m}, 125-250 \mu \mathrm{m}, 250-500$

$\mu \mathrm{m})$

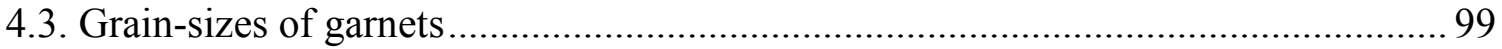

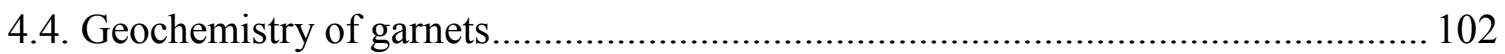

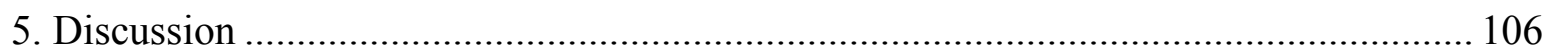

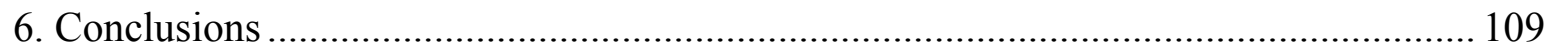

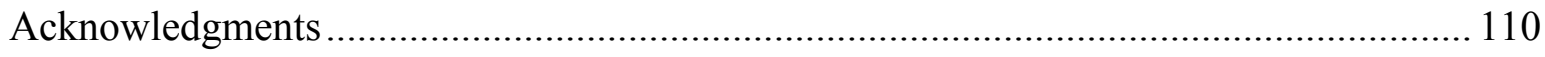

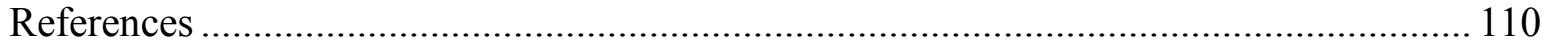

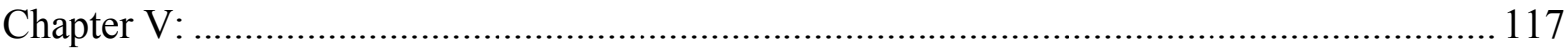

Manuscript IV: Provenance signatures of stream sediments and composition of HP-UHP bedrocks from the Western Gneiss Region, SW Norway ................................................... 117

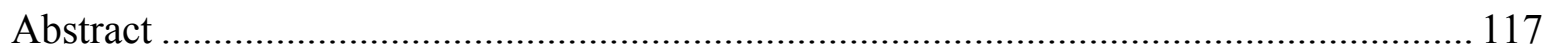

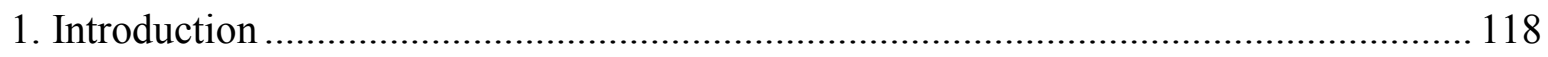

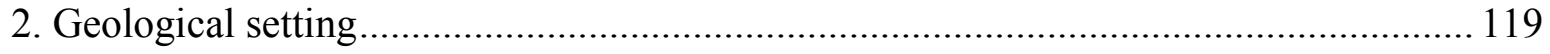

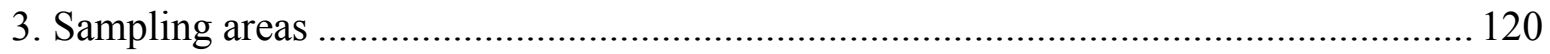

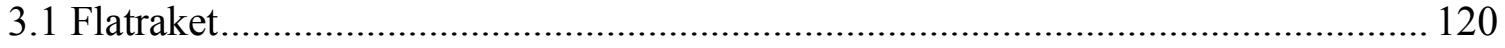

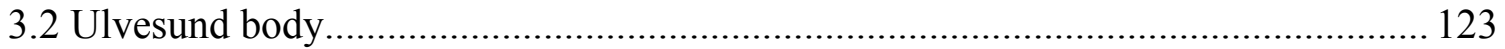

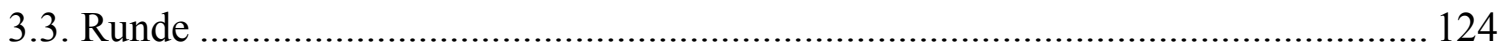

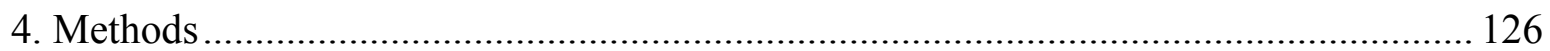

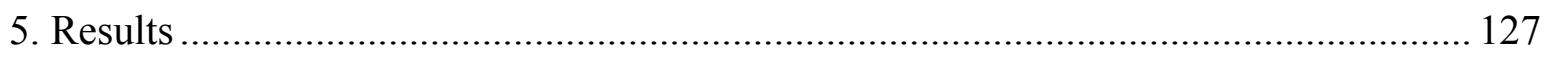

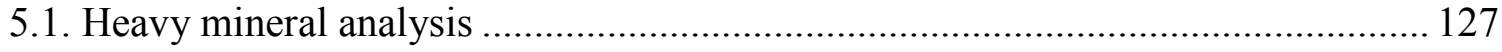

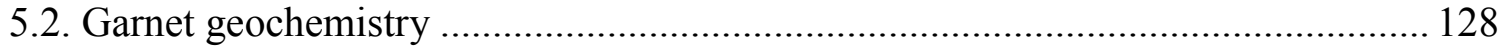

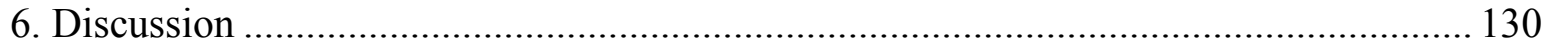

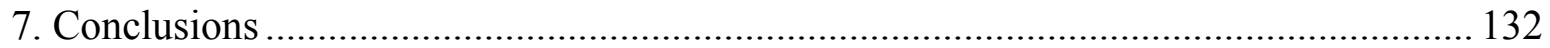

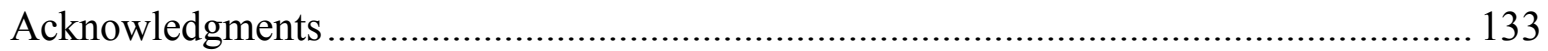

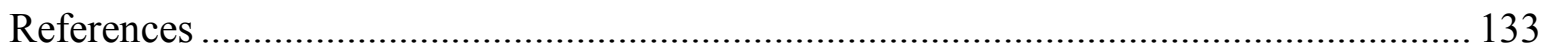

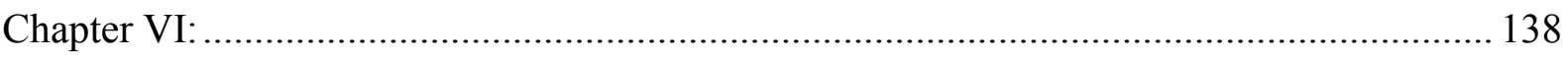

A step-wise classification scheme of garnets for sedimentary provenance analysis: An

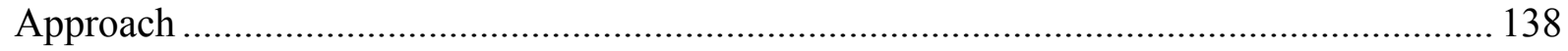

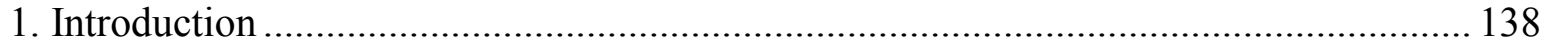

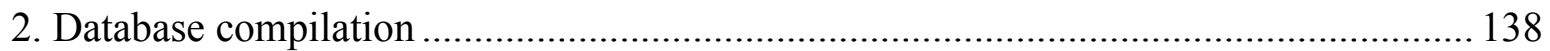

3. Methodological approach for discriminating groups of garnets ................................. 139

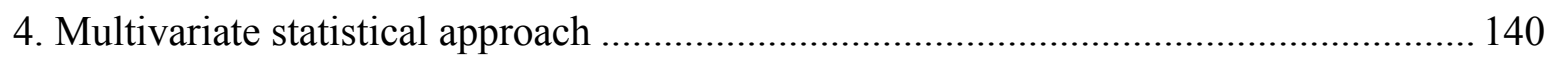


5. Discrimination of garnets from ultramafic rocks (group D) from garnets derived from metamorphic (group A, B, C) and magmatic rocks (E1) 141

6. Discrimination of garnets from magmatic rocks (group E1) from garnets from

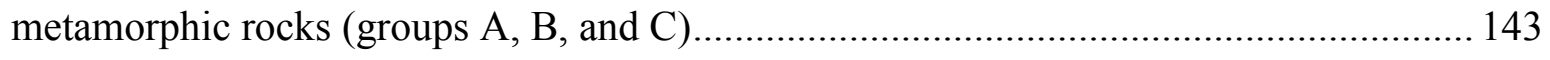

7. Discrimination of garnets from eclogites (group A), amphibolites (group B) and

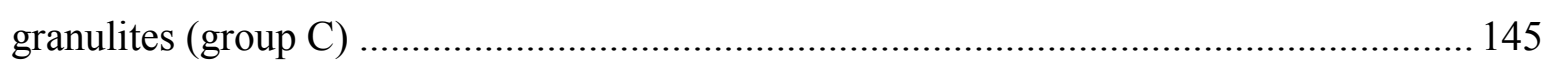

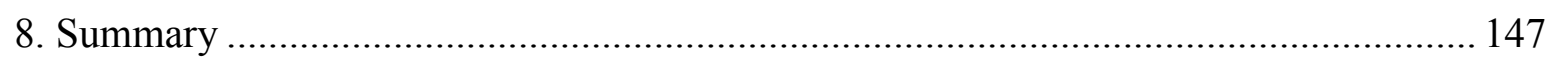

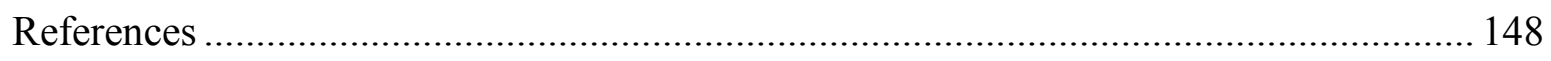

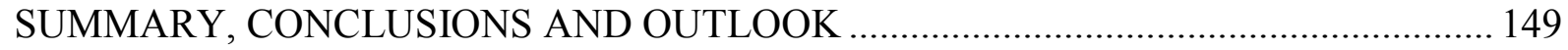

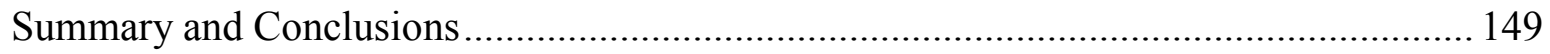

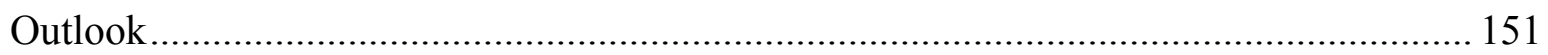




\section{ACKNOWLEDGEMENTS}

Most notably, I would like to thank CASP for providing the funding for my $\mathrm{PhD}$ scholarship through a research grant to Guido Meinhold. Fieldwork and analytical work was financed by the German Research Foundation (DFG grant EY 23/20-1).

I thank Hilmar von Eynatten and Guido Meinhold for their support and patience during the whole time of my thesis and for their constructive discussion. Hilmar von Eynatten and Guido Meinhold supported me at any time in case of questions.

This thesis was only possible with the help of Guido Meinhold who assisted me during fieldwork and helped me in the research of literature. I am grateful to Andrew Morton for the inspiring discussions with him and his helpful advices. I am grateful to Eva Russell and Jan Schönig for their contribution to this study with their bachelor theses.

It was a pleasure to work with a nice team in such a friendly and enjoyable atmosphere as in the Institute of Sedimentology and Environmental Geology in Göttingen. Special thanks to István Dunkl who supported me with the making of the garnet mounts and polishing. I am also grateful to Cornelia Friedrich and Irina Ottenbacher who helped me a lot during laboratory work. A very big thank you goes to Andreas Kronz who assisted me with the electron microprobe analysis and corrections. I owe Raimon Tolosana-Delegado gratitude receiving a lot help for the statistic part in my thesis, which was a major contribution to this study.

Many thanks to all my colleagues and friends Aldo Alván, Melanie Brandmeier, Roos Heisteck, Keno Lünsdorf, Reinhard Wolff, Malte Schindler, Solveig Pospiech, Luca Caracciolo, and Kersten Loewen for the wonderful time in Göttingen.

I wish to thank Ines Ringel, Aldo Alván, Volker Karius, Nils Hocke, and Lena Krippner for emotional support during the whole time of my thesis.

Finally I am grateful to my family, they were always there for me. 


\section{PREFACE}

Included in this doctoral thesis are four articles of which two have been published, one has been submitted and one is not yet submitted, as indicated below. A fifth article is in preparation of which the preliminary concept is presented in Chapter 6.

Supplementary material of each article and chapter is provided on DVD.

Krippner, A., Meinhold, G., Morton, A.C., von Eynatten, H., 2014. Evaluation of garnet discrimination diagrams using geochemical data derived from various host rocks. Sedimentary Geology 306, 36-52.

Krippner, A., Meinhold, G., Morton, A.C., Russell, E., von Eynatten, H., 2015. Grainsize dependence of garnet composition revealed by provenance signatures of modern stream sediments from the western Hohe Tauern (Austria). Sedimentary Geology 321, 25-38.

Krippner, A., Meinhold, G., Morton, A.C., Schönig, J., von Eynatten, H. (in press). Heavy minerals and garnet geochemistry of stream sediments and hardrocks from the Almklovdalen area, Western Gneiss Region, SW Norway: implications for provenance analysis. Sedimentary Geology (Special Issue: WGSG2015).

Krippner, A., Meinhold, G., Morton, A.C., von Eynatten, H. (submitted). Provenance signatures of stream sediments and composition of HP-UHP hardrocks from the Western Gneiss Region, SW Norway: Some lessons learned from heavy mineral analysis and garnet geochemistry. Norwegian Journal of Geology. 


\section{ABSTRACT}

This PhD thesis investigates the application of heavy minerals in sedimentary provenance analysis, with the main focus on garnet geochemistry. The work is mainly based on an intensive literature study, fieldwork, conventional heavy mineral analysis, electron microprobe analysis of garnet, and statistical data evaluation.

The thesis is subdivided into six chapters. After an introduction into the subject (Chapter 1), we make an attempt to evaluate six different garnet discrimination diagrams (one binary diagram and five ternary diagrams) commonly used by many researchers (Chapter 2). A large dataset was compiled $(\mathrm{N}=3532)$ encompassing major element compositions of garnets derived from various host lithologies, including metamorphic, igneous, and mantle-derived rocks, in order to test the applicability of the various discrimination schemes. The dataset contains mineral chemical data collected from the literature complemented with some new data $(\mathrm{N}=530)$ from garnet-bearing metamorphic and ultramafic rocks in Austria and Norway. Discrimination of the tested diagrams only works for a small group of garnets derived from mantle rocks, granulite-facies metasedimentary rocks, and felsic igneous rocks. For other garnet types, the assignment to a certain type of host rock remains ambiguous. We further apply compositional biplot analysis to derive some hints towards future perspectives in detrital garnet discrimination. In Chapter 3 , we present results from fieldwork in the southern Tauern window in Austria. Here, we test the application of heavy minerals and garnet geochemistry for sedimentary provenance analysis for modern stream sediments collected along three rivers draining the Eclogite Zone and adjacent geological source units of the western Hohe Tauern area in the central Eastern European Alps. For comparison with the stream sediments, rock outcrops exposed in this area were also sampled. Additionally, the influence of grain-size is studied in detail by considering grain-size fractions ranging from coarse silt to coarse sand (32 to $1000 \mu \mathrm{m}$ ). Interestingly, in all samples, grossular-rich garnets are more frequent in the smaller grain-sizes and pyrope-rich garnets are more frequent in the coarser grain-sizes. This is controlled by the original finer size distribution of grossular in the source rocks rather than being a hydraulic effect. The data underline strong grain-size control on sediment composition including single grain compositional variations. In Chapter 4, we present heavy mineral data and garnet geochemistry of stream sediments and bedrocks from the 
catchment area draining the Almklovdalen peridotite massif in the Western Gneiss Region in SW Norway. The data reveal that a wider grain-size spectrum than the commonly used grain-size range of 63-125 $\mu \mathrm{m}$ needs to be considered to avoid misleading interpretations. Remarkably is the almost total lack of pyrope-rich garnets in the sediments, which point to the few garnet peridotites exposed in the area. Garnets with pyrope content exceeding $50 \%$ are only found in the 500-1000 $\mu \mathrm{m}$ grain-size fraction. In Chapter 5, we present heavy mineral and garnet geochemical data of recent stream sediments and bedrocks from three different catchment areas (the Flatraket and Ulvesund body and the island of Runde) in the Western Gneiss Region in SW Norway. We want to test to what extent the heavy minerals and the garnet geochemistry from a single stream-sediment sample per catchment reflect the geological situation in the source area. In overall, the heavy mineral and garnet geochemical data very well reflect the geological situation in the source area, which confirms the application and the importance of heavy minerals in sedimentary provenance analysis. Geochemical data of heavy minerals usually show a wider distribution in the sediments than the data of heavy minerals measured in the bedrocks. However, our results demonstrate that this is not always the case. Some garnets measured in the bedrocks, especially lower grade and ultrahigh-grade metamorphic garnets are only of secondary importance or they are lacking in the sediments. In Chapter 6, we have a look which elements are most useful to discriminate between the several garnet bearing groups. We present first ideas about the compilation of our garnet data and for a step-wise classification of garnets. For this we use the data from our compiled database. At the final end we want to establish a new scheme in which detrital garnets are assigned to a specific rock type with the highest probability. However, this is not yet included in this thesis since we need to work more on that subject.

\section{KURZFASSUNG}

Die vorliegende Doktorarbeit befasst sich mit Anwendung von Schwermineralen in der Liefergebietsanalyse mit besonderem Fokus auf der Geochemie von Granat. Die Arbeit basiert im Wesentlichen auf einer gründlichen Literaturrecherche zu 
mineralchemischen Daten von natürlichem Granat aus verschiedenen Ausgangsgesteinen, Geländearbeiten, konventioneller Schwermineralanalyse, mineralchemischen Analysen von Granat an der Elektronenstrahl-Mikrosonde und statistischer Datenauswertung. Die Doktorarbeit ist in sechs Kapitel unterteilt. Nach einer Einführung in das Thema der Arbeit (Kapitel 1) wird die Anwendbarkeit vorhandener Klassifikationsdiagramme von Granat getestet, welche in den meisten Studien benutzt werden um Granat bestimmten Gesteinen zuzuordnen (Kapitel 2). Für diese Studie wurde eine große Datenbank ( $N=3532)$ angelegt, welche Hauptelemente von Granat aus verschiedenen Liefergesteinen enthält, um die Anwendbarkeit der einzelnen Diagramme zu testen. Die Datenbank enthält geochemische Daten von Granat aus verschiedenen metamorphen, magmatischen und ultramafischen Lithologien, welche aus der Literatur entnommen wurden zusammen mit eigenen neuen Daten ( $\mathrm{N}=530)$ von Granat enthaltenen metamorphen und ultramafischen Gesteinen aus Österreich und Norwegen. Die Klassifikation der getesteten Diagramme funktioniert nur für eine kleine Gruppe von Granaten aus Mantelgesteinen, granulitfaziellen metasedimentären Gesteinen und felsischen magmatischen Gesteinen. Für Granate aus anderen Gesteinen bleibt eine Zuordnung schwierig. Weiterhin stellen wir Biplots vor um Anstöße für weitere Arbeiten im Bereich der Granatchemie zu geben. In Kapitel 3 werden die Ergebnisse von den Geländearbeiten im südlichen Tauernfenster in Österreich vorgestellt. Es wird die Anwendbarkeit von Schwermineralen und die der Geochemie von Granat, aus rezenten Flusssedimenten, in der Liefergebietsanalyse getestet. Die Sedimente wurden entlang drei Flussläufen, welche die Eklogitzone und angrenzende geologische Zonen der Hohe Tauern Region der zentralen östlichen europäischen Alpen entwässern, entnommen. Zum Vergleich wurden neben den Flusssedimenten auch Gesteine von Aufschlüssen beprobt. Der Einfluss der Korngröße ist im Detail unter Berücksichtigung der Korngrößenfraktionen von Grobsilt bis Grobsand (32 bis $1000 \mu \mathrm{m}$ ) untersucht worden. Interessant ist, dass in allen Proben grossular-reiche Granate verstärkt in den feineren Fraktionen auftreten und pyrop-reiche Granate verstärkt in den gröberen Fraktionen. Dies ist sehr wahrscheinlich durch die feinere Korngröße in den grossular-reichen Liefergesteinen, als durch einen hydraulischen Effekt zu erklären. Die Daten zeigen eine starke Korngrößenabhängigkeit der Sedimentzusammensetzung inklusive Variationen in Einzelkörnern. In Kapitel 4 werden die Ergebnisse von den Geländearbeiten in der Western Gneiss Region in 
SW-Norwegen vorgestellt. Das Untersuchungsgebiet umfasst das Almklovdalen Peridotitmassiv. Detritische Schwermineraldaten und geochemische Daten von Granat von Flusssedimenten und Festgesteinen aus dem Einzugsgebiet, welches das Almklovdalen Peridotitmassiv in SW-Norwegen umfasst zeigen, dass ein breiteres Korngrößenspektrum als das für gewöhnlich benutzte Spektrum von 63-125 $\mu \mathrm{m}$ benötigt wird um irreführende Interpretationen zu vermeiden. Auffällig ist das Fehlen von pyrop-reichem Granat in den Flusssedimenten, welche auf die wenigen Granat-Peridotite im Liefergebiet hinweisen. Granate mit > 50\% Pyropanteil treten nur in der gröbern Fraktion auf $(500-1000 \mu \mathrm{m})$. In Kapitel 5 präsentieren wir Schwermineraldaten und geochemische Daten von Granat von rezenten Flusssedimenten und Festgesteinen von drei verschiedenen Einzugsgebieten (Flatraket, Ulvesund und Runde) im West Gneis Komplex in Südwest Norwegen. In dieser Studie möchten wir testen, inwieweit die Schwerminerale, sowie auch die Granatgeochemie einer einzelnen Sedimentprobe je Einzugsgebiet, die geologische Situation im Untersuchungsgebiet wiederspiegeln. Im Gesamten spiegeln die Daten der Schwerminerale und die von Granat sehr gut die geologische Situation im Liefergebiet wieder, was die Anwendbarkeit und Wichtigkeit der Schwermineralanalysen in der sedimentären Provenienzanalyse zum Ausdruck bringt. Geochemische Daten von Schwermineralen zeigen häufig eine breiter gefächerte Verteilung in Sedimenten als in Festgesteinen. Dennoch zeigen die Ergebnisse, dass dies nicht immer der Fall ist. Manche Granate in den Festgesteinen, vor allem die niedriggradig- und ultrahochgradig metamorphen Granate sind sind oft nur zweitrangig von Bedeutung oder fehlen gänzlich in den Sedimenten. In Kapitel 6 wird aufgezeigt welche Hauptelemente wichtig für die Klassifikation von Granat aus verschiedenen Gesteinstypen sind. Wir stellen erste Ideen und Ansätze vor, wie man Schritt für Schritt die einzelnen Granatgruppen sinnvoll einteilen kann. Dafür werden die Daten aus der angelegten Datenbasis verwendet. Am Ende soll eine Tabelle oder ein Diagramm entwickelt werden, welches detritische Granate mit einer bestimmten Wahrscheinlichkeit bestimmten Gesteinstypen zuordnet. Dies ist aber nicht mehr Inhalt des Kapitels, da es noch weitere Bearbeitung braucht. 


\section{Chapter I:}

\section{INTRODUCTION AND OUTLINE OF THIS THESIS}

\section{About the project}

The PhD scholarship was financed by CASP, formerly known as Cambridge Arctic Shelf Programme. CASP is a non-for-profit charitable trust, dedicated to fundamental geoscientific research in prospective hydrocarbon basins, affiliated to the Department of Earth Sciences at the University of Cambridge (http://www.casp.cam.ac.uk/). The project itself was developed and performed at the Geoscience Center of the University of Göttingen, focusing on the application of heavy minerals with the main focus on the geochemistry of garnets in sedimentary provenance analysis. Working on this thesis started in December 2011. Fieldwork and analytical work was financed by the German Research Foundation (DFG grant EY 23/20-1). During this project two bachelor theses have been prepared. Part of the data of Manuscript II is obtained from the bachelor thesis of Eva Russell and part of the data of Manuscript III is taken from the bachelor thesis of Jan Schönig.

\section{Outline of the thesis}

The integration of mineralogical, geochemical and radiometric data of heavy minerals is a powerful tool in sedimentary provenance analysis. Specific parageneses of detrital non-opaque heavy minerals enable direct links between source rocks and sediments (e.g., Mange and Maurer, 1992; Morton, 2012). Ideally, source rock mineralogy reflects the composition of heavy mineral assemblages in the sediment, but many other processes operate during the sedimentary cycle and obscure the original provenance signal (Morton, 2012), for example, weathering in the source area, abrasion, hydrodynamic sorting during transport and deposition, weathering during alluvial storage on flood plains, and diagenesis (Morton and Hallsworth, 1999). Weathering may cause modifications of heavy mineral composition in the source rock, during transport (alluvial storage) and at deposition. The extent of modification depends on the physiographic setting and on the climate (e.g., Morton 2012). There is no evidence of mechanical abrasion in river systems like the Mississippi (Russell, 
1937), the Nile (Shukri, 1949; Garzanti et al., 2006), the Brahmaputra (Garzanti et al., 2010) and the Rhine (van Andel, 1950), and therefore, this process appears to be negligible for provenance studies (Morton, 2012). However, loss of heavy minerals remains possible (Morton, 2012). Density, diameter and shape control the hydrodynamic behavior of heavy minerals, and grains with similar hydrodynamic behavior are deposited together, which needs to be considered carefully (Komar, 2007; Garzanti et al., 2008). However, the strongest effect that obscures the provenance signal is burial diagenesis. During burial diagenesis unstable phases can be lost. At burial depth the initial high diversity of heavy minerals decrease dramatically. An indication of dissolution is the presence of corrosion textures on grain surfaces (e.g., Edelman and Doeglas, 1932, 1934; Morton, 2012) (Fig. 1).

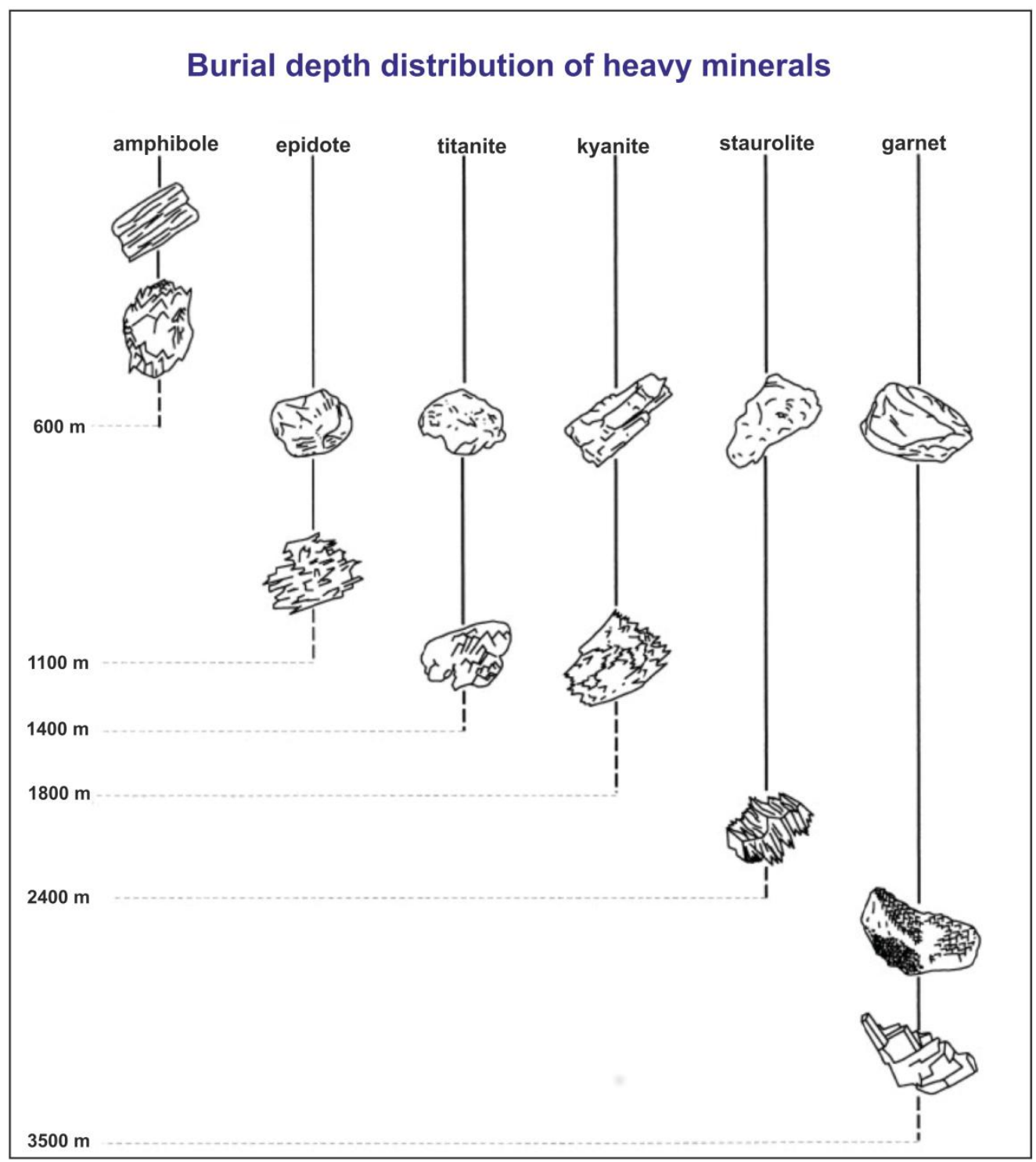

Fig. 1. Burial depth distribution of heavy minerals in Upper Paleocene sandstones of the central North Sea, showing the decrease in mineral diversity with increasing burial caused by dissolution of unstable minerals (modified after Morton and Hallsworth, 1999). 
The most stable minerals under both deep burial and acidic weathering are rutile, zircon, and tourmaline (Fig. 2). Apatite is very resistant against burial diagenesis, but least stable in acidic environments. Garnet is relatively stable against burial diagenesis and in acidic environments. Relatively unstable are olivine, pyroxene, and amphibole (Fig. 2).

\section{Relative stability of detrital heavy minerals}

In deep burial conditions

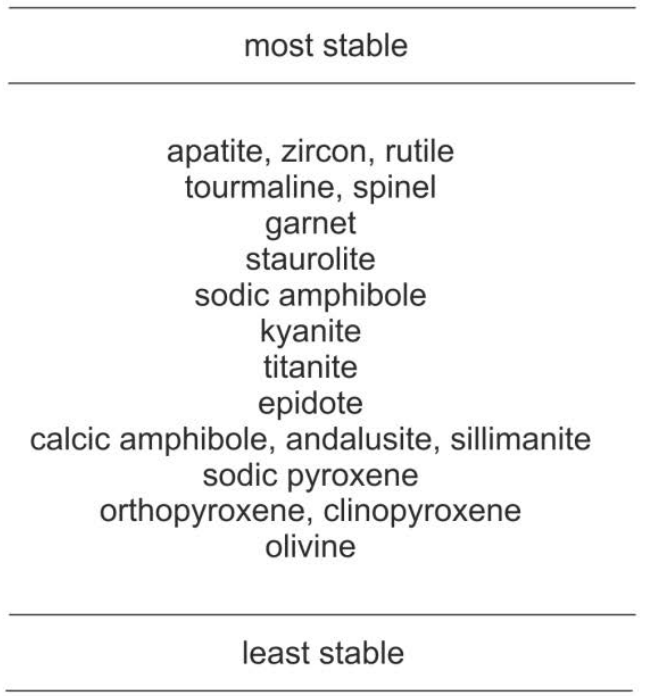

modified from Morton and Hallsworth (2007)

\section{In acidic weathering}

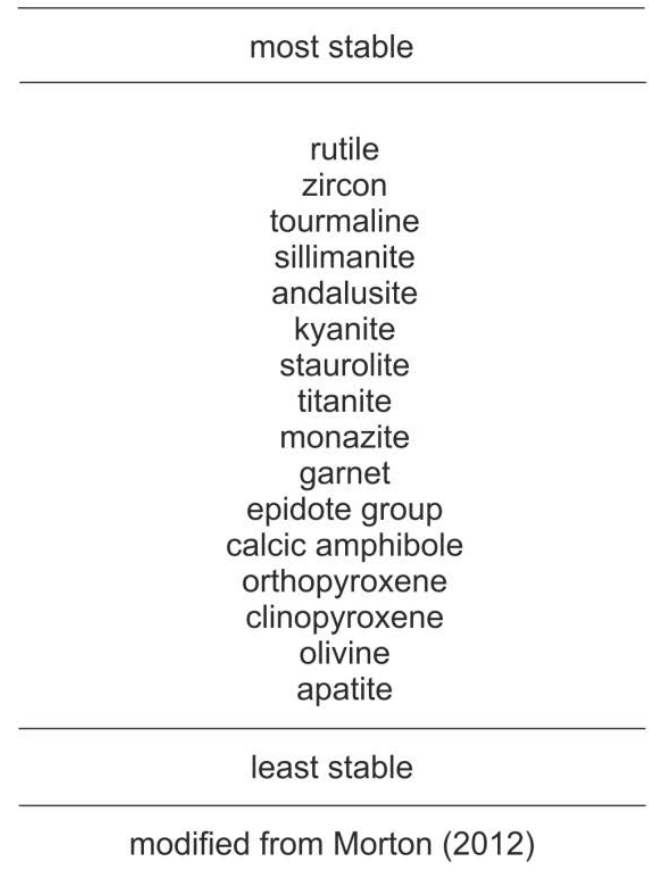

Fig. 2. Relative stability of detrital heavy minerals under deep burial and acidic weathering conditions.

Another problem is the grain-size. Using the entire grain size range, the resulting data can be heavily affected by differences in hydrodynamics between samples. Most commonly the 63-125 $\mu \mathrm{m}$ grain-size fraction is used because this grain-size range commonly covers the entire heavy mineral spectrum in the source area (Fig. 3 ). It is assumed that this approach minimizes the possible lack of diagnostic minerals. Minerals of an original coarser grain-size distribution in the source rock occur in the finer grain-size fractions, because they are crushed through hydraulic or other mechanical processes (Morton, 2012). Nevertheless, heavy minerals segregate according to their grain-size, density, and shape (Morton and Hallsworth, 1999; 
Garzanti et al., 2008, 2009, 2010). When only considering a narrow grain-size range, some minerals of the source rocks can be lacking in the sediments, which can lead to misleading results. This does not pose any problems when the geological situation in the study area is well known, but source to sink relationships may be obscured in ancient sedimentary systems, where the sediments are the only evidence of the original palaeotectonic and palaeogeographic setting. For some minerals the relation between grain size and frequencies has been determined (Fig. 3).

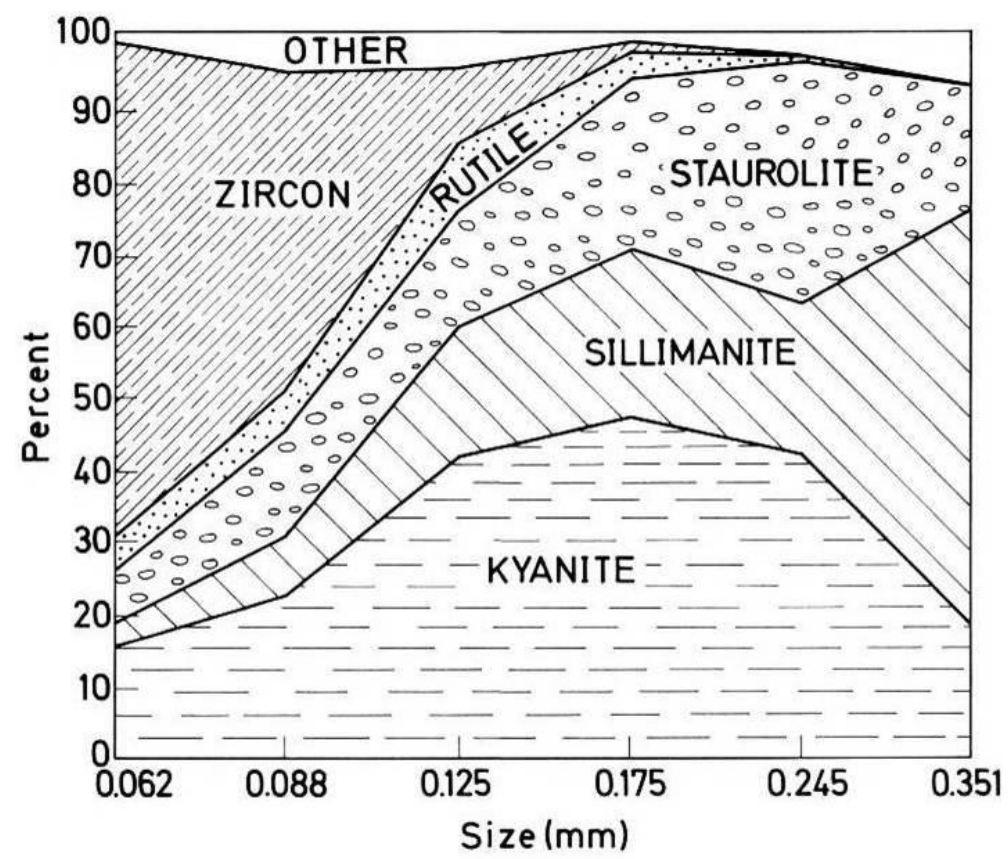

Fig. 3. Relation between grain-size and heavy mineral frequencies. Pliocene-Pleistocene Lafayette sand, western Kentucky. Taken from Pettijohn et al. (1972).

For sands and sandstones, which suffered one or more periods of subaerial exposure or deep burial diagenesis, the application of heavy minerals is limited due to selective dissolution of mineral species. Pyroxene, amphiboles and epidotes are relatively unstable under both, deep burial conditions and in acidic environments and studies on these minerals are therefore limited. The heavy mineral garnet is relatively resistant under burial conditions and relatively stable in acidic environments under normal conditions, as shown in Figures 1 and 2 (see also Deer et al., 1992). That is one reason why garnet is a useful mineral in sedimentary provenance analysis. There are several other reasons why garnet is the focus of this research project.

For more than 25 years the mineral chemistry of heavy minerals has been widely used to identify and characterise sediment source areas (e.g., Morton 1985; Haughton and Farrow, 1989; von Eynatten and Gaupp, 1999; Mange and Morton, 
2007). Garnet offers a good opportunity for accurate analysis (Morton, 2012). Additionally, it exists in many different kind of rocks, such as crustal and mantle rocks (e.g., Deer et al., 1992; Seifert and Vrána, 2005). Due to its high density, it is a common constituent in the heavy minerals suites of clastic sediments and sedimentary rocks (e.g., Pettijohn, 1941). Another important point is that garnet has a wide range of major element and also trace element composition, which reflect the bulk composition of the source rock and its pressure and temperature conditions. Numerous studies underline the strong evidence that certain garnet composition can be related to a specific source rock (e.g., Morton et al., 2004; Mange and Morton, 2007; Aubrecht et al., 2009). For example, detrital Cr-pyrope garnets can be related to mantle-derived xenoliths in diamond-bearing intrusive rocks and therefore have important implications for diamond exploration (Fipke et al., 1995; Schulze et al., 1997; Seifert and Vrána, 2005; Grütter et al., 2004). For these reasons, the mineral chemistry of detrital garnet has important implications for the identification of the potential lithologies exposed in the source area and their evolution through time. This is very important, especially when sediment derived from various sources and geodynamic settings might be mixed together. Yet there is no clear quantitative understanding of what garnet types come from which host lithologies. Several discrimination diagrams for garnets exist and are used by many researchers, but a statistical analysis of their reliability is still missing. This $\mathrm{PhD}$ thesis tackles some of these issues. In a first part, a thorough literature study to collect mineral chemical data of garnet from various host lithologies was done to create a large garnet database. This database is presented in Chapter 2. Also general information about the heavy mineral garnet and its application in sedimentary provenance analysis are given in this chapter. Furthermore, we make an attempt to evaluate the application of existing garnet discrimination diagrams, commonly used by many researchers in sedimentary provenance analysis, with the data collected from the literature and some new garnet data from own fieldwork. In the second part of the thesis, case studies from different fieldwork areas are presented. In these case studies, the source to sink relationship was analysed in order to test the general application of garnet in sedimentary provenance analysis. Fieldwork was done in Austria and Norway. There, the geological setting allows to easily collect samples from bedrocks and recent sediments, because metamorphic rocks are well exposed, easily accessible and pre-Holocene sediment influx can be regarded as insignificant so that 
contamination with garnets from other source rocks than those exposed in the study areas can be excluded.

Fieldwork in Austria focused on medium- to high-grade metamorphic rocks, like micaschists and eclogites, of the southern Tauern window. Fieldwork in Norway focused on high- and ultrahigh-grade metamorphic rocks of the Nordfjord-Stadlandet and the Sørøyane domains of the Western Gneiss Region.

In both study areas, a range of source rocks as well as stream sediments from adjacent river systems were collected in order to test to what extent the heavy minerals and the garnet geochemistry reflect the situation in the source area. Fieldwork was followed by mineral chemical analysis using the electron microprobe. The results from fieldwork in Austria are presented in Chapter 3. Results from the fieldwork in Norway are presented in Chapters 4 and 5. Additionally, several grainsize fractions were analysed in detail and are presented in Chapters 3 and 4 . One aim of this research is to study the relation between garnet and its source rock for a better understanding of the source to sink relationship in the geological record.

Another aim is a probabilistic approach that means assigning each garnet composition a probability of belonging to a specific source-rock type. This study is still in process and needs further investigations. A first step is to analyse the characteristics of the individual garnet types, for example, which elements are important to differentiate the individual garnet groups. First investigations, ideas and results are presented in Chapter 6.

\section{References}

Aubrecht, R., Méres, Š., Sýkora, M., Mikus, T., 2009. Provenance of the detrital garnets and spinels from the Albian sediments of the Czorsztyn Unit (Pieniny Klippen Belt, Western Carpathians, Slovakia). Geologica Carpathica 60, 463483.

Deer, W.A., Howie, R.A., Zussman, J., 1992. An introduction to rock-forming minerals. Longman Group Ltd, Harlow, UK, 712 pp.

Edelman, C.H., Doeglas, D.J., 1932. Reliktstructuren detritischer Pyroxene and Amphibole. Tschermaks Mineralogische und Petrographische Mitteilungen 42, 482-490. 
Edelman, C.H., Doeglas, D.J., 1934. Über Umwandlungserscheinungen an detritischem Staurolith und anderen Mineralien. Tschermaks Mineralogische und Petrographische Mitteilungen 44, 225-234.

Fipke, C.E., Gurney, J.J., Moore, R.O., 1995. Diamond exploration techniques emphasising indicator mineral geochemistry and Canadian examples. Geological Survey of Canada Bulletin 423, 86 pp.

Garzanti, E., Andò, S., Vezzoli, G., Megid, A.A.A., Kammar, A., 2006. Petrology of Nile River sands (Ethiopia and Sudan): sediment budgets and erosion patterns. Earth and Planetary Science Letters 252, 327-341.

Garzanti, E., Andò, S., Vezzoli, G., 2008. Settling-equivalence of detrital minerals and grain-size dependence of sediment composition. Earth and Planetary Science Letters 273, 138-151.

Garzanti, E., Andò, S., Vezzoli, G., 2009. Grain-size dependence of sediment composition and environmental bias in provenance studies. Earth and Planetary Science Letters 277, 422-432.

Garzanti, E., Resentini, A., Vezzoli, G., 2010. Detrital fingerprints of fossil continentalsubduction zones (Axial Belt Provenance, European Alps). Journal of Geology 118, 341-362.

Grütter, H.S., Gurney, J.J., Menzies, A.H., Winter, F., 2004. An updated classification scheme for mantle-derived garnets, for use by diamond explorers. Lithos 77 , 841-857.

Haughton, P.D.W., Farrow, C.M., 1989. Compositional variation in Lower Old Red Sandstone detrital garnets from the Midland valley of Scotland and the AngloWelsh Basin. Geological Magazine 126, 373-396.

Komar, P.D., 2007. The entrainment, transport and sorting of heavy minerals by waves and currents. In: Mange, M.A., Wright, D.T. (Eds.), Heavy Minerals in Use. Developments in Sedimentology 58, 3-48.

Mange, M.A, Maurer, H.F.W, 1992. Heavy minerals in colour. Chapman and Hall, London, $147 \mathrm{pp}$.

Mange, M.A., Morton, A.C., 2007. Geochemistry of heavy minerals. In: Mange, M.A., Wright, D.T. (Eds.), Heavy Minerals in Use. Developments in Sedimentology 58, Elsevier, Amsterdam, 345-391. 
Morton, A.C., 1985. A new approach to provenance studies: electron microprobe analysis of detrital garnets from Middle Jurassic sandstones of the northern North Sea. Sedimentology 32, 553-566.

Morton, A.C. and Hallsworth, C.R., 2007. Stability of detrital heavy minerals during burial diagenesis. In: Mange, M. and Wright, D.K. (Eds.), Heavy Minerals In Use. Developments in Sedimentology, 58, 215-245.

Morton, A.C., 2012. Value of heavy minerals in sediments and sedimentary rocks for provenance, transport history and stratigraphic correlation. In: Sylvester, P. (Ed.), Quantitative Mineralogy and Microanalysis of Sediments and Sedimentary Rocks. Mineralogical Association of Canada Short Course Series 42, pp. 133165.

Morton, A.C., Hallsworth, C.R., 1999. Processes controlling the composition of heavy mineral assemblages in sandstones. Sedimentary Geology 124, 3-29.

Morton, A., Hallsworth, C., Chalton, B., 2004. Garnet compositions in Scottish and Norwegian basement terrains: a framework for interpretation of North Sea sandstone provenance. Marine and Petroleum Geology 21, 393-410.

Pettijohn, F.J., 1941. Persistence of heavy minerals and geological age. Journal of Geology 49, 610-625.

Pettijohn, F.J., Potter, P.E., Siever, R., 1972. Sand and sandstone. $1^{\text {st }}$ edition, Springer, New York, 618 pp.

Russell, R.D., 1937. Mineral composition of Mississippi River sands. Bulletin of the Geological Society of America 48, 1307-1348.

Schulze, D.J., 1997. The significance of eclogite and Cr-poor megacryst garnets in diamond exploration. Exploration and Mining Geology 6, 349-366.

Seifert, A.V., Vrána, S., 2005. Bohemian garnet. Bulletin of Geosciences 80, 113124.

Shukri, N.M, 1949. The mineralogy of Nile sediments. Quarterly Journal of the Geological Society of London 105, 511-529.

van Andel, T.H., 1950. Provenance, transport and deposition of Rhine sediments. Veenman en Zonen, Wageningen, $129 \mathrm{pp}$.

von Eynatten, H., Gaupp, R., 1999. Provenance of Cretaceous synorogenic sandstones in the Eastern Alps: constraints from framework petrography, heavy mineral analysis and mineral chemistry. Sedimentary Geology 124, 81-111. 


\section{Manuscript I: Evaluation of garnet discrimination diagrams using geochemical data of garnets derived from various host rocks}

Anne Krippner ${ }^{1, *}$, Guido Meinhold ${ }^{1}$, Andrew C. Morton ${ }^{2,3}$, Hilmar von Eynatten ${ }^{1}$

${ }^{1}$ Department of Sedimentology and Environmental Geology, University of Göttingen, Goldschmidtstraße 3, 37077 Göttingen, Germany

${ }^{2}$ CASP, University of Cambridge, West Building, 181A Huntingdon Road, Cambridge CB3 ODH, United Kingdom

${ }^{3} \mathrm{HM}$ Research Associates, 2 Clive Road, Balsall Common, West Midlands CV7 7DW, United Kingdom

Published in: Sedimentary Geology 306 (2014): 32-52

\section{Abstract}

This work is an attempt to evaluate six different garnet discrimination diagrams (one binary diagram and five ternary diagrams) commonly used by many researchers. The mineral chemistry of detrital garnet is a useful tool in sedimentary provenance studies, yet there is no clear-cut understanding of what garnet type originates from which host lithology. Several discrimination diagrams exist for garnet showing distinct compositional fields, separated by strict boundaries that are thought to reflect specific types of source rocks. For this study, a large dataset was compiled $(N=3532)$ encompassing major element compositions of garnets derived from various host lithologies, including metamorphic, igneous, and mantle-derived rocks, in order to test the applicability of the various discrimination schemes. The dataset contains mineral chemical data collected from the literature complemented with some new data $(\mathrm{N}=530)$ from garnet-bearing metamorphic and ultramafic rocks in Austria and Norway. Discrimination of the tested diagrams only works for a small group of garnets derived from mantle rocks, granulite-facies metasedimentary rocks, and 
felsic igneous rocks. For other garnet types, the assignment to a certain type of host rock remains ambiguous. This is considered insufficient and therefore the evaluated diagrams should be used with great care. We further apply compositional biplot analysis to derive some hints towards future perspectives in detrital garnet discrimination.

Keywords: provenance; heavy minerals; garnet chemistry; discrimination; compositional biplot

\section{Introduction}

For more than 25 years, the mineral chemistry of heavy minerals has been widely used to identify, discriminate, and characterise sediment source areas (see recent review in von Eynatten and Dunkl, 2012). Particularly, the heavy mineral garnet can be used for the identification of the potential lithologies exposed in the source area. Garnet is a particular useful mineral in provenance research because of its wide range of major element composition, its high importance in defining metamorphic conditions, and its comparative stability during transport and burial diagenesis (e.g., Wright, 1938, Tröger, 1952, Zemann, 1962, Nandi, 1967, Morton, 1985 and Deer et al., 1992). Morton (1985) was the first to undertake detrital garnet provenance analysis using electron microprobe analysis, in a study of Middle Jurassic sandstones from the North Sea. Since then, this method has been widely applied to determine the provenance of sediments (e.g., Haughton and Farrow, 1989, Takeuchi, 1994, von Eynatten and Gaupp, 1999 and Sabeen et al., 2002). The chemical composition of garnet depends on host rock bulk composition as well as its pressure and temperature history. Therefore the major, trace, and rare earth element composition of garnet can be used to analyse the evolution of mantle and crustal rocks (Harangi et al., 2001, Schulze, 2003, Cookenboo and Grütter, 2010 and Heimann et al., 2011, and references therein). Certain garnet compositions have been empirically related to specific sources and, therefore, detrital garnet has been increasingly useful in sedimentary provenance analysis (e.g., Morton et al., 2004, Mange and Morton, 2007, Keulen et al., 2008, Aubrecht et al., 2009, Biernacka and Józefiak, 2009, Meinhold et al., 2010, Morton et al., 2011, Wotzlaw et al., 2011, Andò et al., 2013 and Suggate and Hall, 2013). Garnet chemistry also has important provenance applications in archaeology, where the mineral chemical composition is 
used as a fingerprint to trace the source of gemstone garnet, thereby giving insights into ancient trade routes from the Far East to Europe and within Europe (e.g., Farges, 1998, Quast and Schüssler, 2000 and Mathis et al., 2008).

Garnet is classified as a group of cubic nesosilicates with the general formula $\mathrm{X}_{3} \mathrm{Y}_{2} \mathrm{Si}_{3} \mathrm{O}_{12}$. Altogether, there are fourteen end-member compositions within the garnet group (Grew et al., 2013). The elements $\mathrm{Fe}^{2+}, \mathrm{Ca}^{2+}, \mathrm{Mg}^{2+}$, and $\mathrm{Mn}^{2+}$ are commonly situated in the $\mathrm{X}$ position, and $\mathrm{Al}^{3+}, \mathrm{Fe}^{3+}$, and $\mathrm{Cr}^{3+}$ are usually in the $\mathrm{Y}$ position. The most common end-member species are almandine $\left(\mathrm{Fe}_{3} \mathrm{Al}_{2} \mathrm{Si}_{3} \mathrm{O}_{12}\right)$, pyrope $\left(\mathrm{Mg}_{3} \mathrm{Al}_{2} \mathrm{Si}_{3} \mathrm{O}_{12}\right)$, spessartine $\left(\mathrm{Mn}_{3} \mathrm{Al}_{2} \mathrm{Si}_{3} \mathrm{O}_{12}\right)$, grossular $\left(\mathrm{Ca}_{3} \mathrm{Al}_{2} \mathrm{Si}_{3} \mathrm{O}_{12}\right)$, andradite $\left(\mathrm{Ca}_{3}(\mathrm{Fe}, \mathrm{Ti})_{2} \mathrm{Si}_{3} \mathrm{O}_{12}\right)$, and uvarovite $\left(\mathrm{Ca}_{3} \mathrm{Cr}_{2} \mathrm{Si}_{3} \mathrm{O}_{12}\right)$. Natural garnet usually consists of a solid solution of these end-members in highly varying proportions. Garnet is a common mineral of a wide variety of metamorphic rocks and rarely occurs as a primary magmatic mineral in igneous rocks and tuffs (e.g., Miller and Stoddard, 1981 and Patranabis-Deb et al., 2008). Garnet is also frequent in mantlederived rocks and is often embedded amongst mineral inclusions in diamonds. In contrast to mantle-derived olivine and pyroxene, garnet is more stable during dispersion and alteration (Pettijohn, 1941, Morton and Hallsworth, 1999 and Grütter et al., 2004). Because garnet displays diagnostic compositional characteristics, it is an interesting mineral for diamond exploration (e.g., Nowicki et al., 2003). Garnet can also be a major constituent in the heavy mineral spectra of sediments and sedimentary rocks (e.g., Pettijohn, 1941, Morton, 1985, Takeuchi, 1994 and Sabeen et al., 2002).

Although garnet chemical composition is a widely used tool in sedimentary provenance analysis, there is no clear-cut and quantitative understanding of what garnet type originates from which host lithology. A number of discrimination diagrams for garnet have been proposed in the literature. They are mainly binary and ternary diagrams where discrimination fields are drawn as strict boundaries by solid lines and some of them show distinct overlap between discrimination fields (e.g., Harangi et al., 2001, Grütter et al., 2004, Mange and Morton, 2007 and Aubrecht et al., 2009). Given the complex controls on garnet composition, such strict boundaries appear to be unlikely. To approach this problem, we compiled a large dataset $(\mathrm{N}=3532)$ based on literature and own data on major element geochemistry of garnet derived from various host lithologies in order to test the reliability of the various discrimination 
schemes. Finally, future perspectives for a better discrimination of garnets derived from different host rocks are presented using compositional biplot analysis.

\section{Garnet sources}

\subsection{Metamorphic garnet}

The majority of garnet occurs in metamorphic rocks covering a broad range of pressure $(\mathrm{P})$ and temperature $(\mathrm{T})$ conditions, and protolith compositions. Metamorphic garnets are commonly characterised through zoning with respect to Fe-Mg-Mn, show resorption zones, and usually have inclusions (e.g., PatranabisDeb et al., 2008, and references therein). Inclusions in garnet are useful indicators of metamorphic grade. For example, inclusions of omphacite with a high jadeite content point to eclogite-facies host rocks and are also common in ultrahigh-pressure (UHP) metamorphic rocks (Desmons and Smulikowski, 2004, Schmid et al., 2004 and Méres et al., 2012). Coesite inclusions in garnet also point to UHP metamorphic conditions (e.g., Wang and Liou, 1991, Wang et al., 1992, Okay, 1993, Cong et al., 1995, Liu and Liou, 1995, Tabata et al., 1998 and Petermann et al., 2009). The presence of kyanite and rutile inclusions in pyrope-rich garnet indicates high-pressure origin (Méres et al., 2012). The structure and distribution of inclusions give further information about the formation of a rock. For example, a curvy distribution or snowball structure is often observed in deformed rocks (e.g., EscuderViruete et al., 2000).

\subsection{Igneous garnet}

Primary igneous garnets are rare and can only develop under restricted conditions; hence, they give useful information about the geodynamics of magma genesis and pressure and temperature conditions (e.g., Green, 1977, Green, 1992 and Harangi et al., 2001). Their appearance in igneous rocks is often restricted to granitoids and acid volcanic rocks (René and Stelling, 2007). There exist three different theories about the origin of garnet in igneous rocks: (i) formation during partial melting as a restite phase (e.g., White and Chappell, 1977, Vennum and Meyer, 1979, Allan and Clarke, 1981 and Stone, 1988), (ii) formation through low-pressure precipitates from a highly fractionated peraluminous granitic melt (e.g., Hall, 1965, Allan and Clarke, 1981, Miller and Stoddard, 1981 and Harrison, 1988), or (iii) formation through 
transportation of high-pressure phenocrysts to the Earth's crust (e.g., Green, 1977 and René and Stelling, 2007). Restite means here the solid remain of a plutonic or volcanic rock resulting from partial melting (Chappell and White, 1991 and Sheibi et al., 2010). It is important to know if these garnets are of phenocrystic or xenocrystic origin. However, great care must be taken when chemical composition is used to distinguish between phenocrystic and xenocrystic garnets, because they have a wide compositional range depending on bulk-rock composition, mineral assemblages, and P-T conditions (e.g., Spear, 1993 and Kawabata and Takafuji, 2005).

Garnet found in pegmatites is commonly a Mn-rich almandine-spessartine solid solution (Manning, 1983). Spessartine-rich almandine-spessartine garnets are stable within a granitic melt at pressures below 5 kbar. With higher Mn content garnet is stable at lower pressures below $1 \mathrm{kbar}$ at $750{ }^{\circ} \mathrm{C}$ (Weisbrod, 1974). There exists a relationship between the concentrations of $\mathrm{Fe}^{2+}$ and $\mathrm{Mn}$ and the geochemical evolution of zoned pegmatite bodies. It has been observed that $\mathrm{Mn}$ content increases from the wall to the core whereas $\mathrm{Fe}^{2+}$ decreases (Baldwin and von Knorring, 1983 and Whitworth, 1992). There is also a correlation between $\mathrm{OH}$ in garnets and pegmatite evolution. $\mathrm{OH}$ in spessartine-almandine garnets ranges up to $0.1 \mathrm{wt} \%$, whereas in grossular-rich garnets, $\mathrm{OH}$ exists in higher concentrations due to substitution of $\mathrm{SiO}_{4}$ by $\mathrm{O}_{4} \mathrm{H}_{4}$ (hydrogarnet substitution) (Arredondo et al., 2001).

As mentioned above, inclusions in garnets can offer clues about their origin. Besides mineral inclusions, there can also be melt inclusions. Their presence in a mineral implies that the mineral grew whilst coexisting with the melt (Kawabata and Takafuji, 2005). The absence of metamorphic inclusions in garnet may point to a magmatic origin. The grain morphology is another important criterion for the origin of a mineral. Euhedral garnets point to rapid ascent of magma and their formation in equilibrium with the host magma (Gilbert and Rogers, 1989, Day et al., 1992 and Kawabata and Takafuji, 2005). For example, garnets from the East Kunlun porphyry of the NE Tibetan Plateau show concentric zoning and have a euhedral shape (Yuan et al., 2009).

\subsection{Ultramafic and mantle-derived garnet}

Garnets in mantle-derived rocks play an important role for diamond exploration (e.g., Nowicki et al., 2003). Eclogite and peridotite garnet xenocrysts and low-Cr 
megacrysts found in kimberlites represent upper mantle material and hence constitute a source for diamonds (Schulze, 1997). In fact, Cr-pyrope garnet is a minor common mineral in ultramafic rocks but it is also used as an indicator mineral in diamond exploration (Fipke et al., 1995 and Seifert and Vrána, 2005). Orogenic garnet peridotites are found within orogenic belts because of subduction and/or late stage continent collision. Cratonic garnet peridotite xenoliths within cratons are usually entrained in ultramafic volcanic rocks and can be related to partial melting of lower mantle and/or mantle plume, whereas off-cratonic garnet peridotite xenoliths are usually preserved in mafic and alkaline volcanic rocks, which occur mostly within the margin of cratons (Su et al., 2011).

The colour of garnets can also be of importance. Seifert and Vrána (2005) studied garnets from the Bohemian Massif, which primarily derived from Iherzolites and peridotites, and found that there is a close linkage between colour and $\mathrm{Cr}_{2} \mathrm{O}_{3}$ content. The garnets with high $\mathrm{Cr}$-content are violet in colour, whilst others are mostly red.

\subsection{Detrital garnets}

In magmatic and metamorphic petrology, the host rock of garnet is obvious because garnet occurs in situ in the analysed rock specimen. This is not the case in sedimentary petrology where garnet, if present, occurs as an accessory detrital component, i.e. the original paragenesis is not known. Detrital heavy minerals are used for establishing source to sink relationships, which may be obscured in ancient sedimentary systems as source regions may be eroded and leaving the sedimentary rocks as the only evidence of the original palaeotectonic setting (e.g., Krippner and Bahlburg, 2013). River sediments represent averaged samples of the rocks within the drainage basin. However, exotic detritus might have been delivered during repeated ice sheet advances, as shown, for example, in NW European sediments (Morton et al., 2004). The relative abundances of minerals are effected through hydraulic processes. The effects of these processes depend on heavy mineral grain-size, density, and shape (e.g., Morton and Hallsworth, 1999, Garzanti et al., 2008, Garzanti et al., 2009 and Garzanti et al., 2010). Even within a single mineral group, sorting due to different sizes and densities can be observed. For example, the almandine-rich garnet species are concentrated in the finer fractions in contrast to less dense garnet species (Schuiling et al., 1985, Andò, 2007 and Garzanti et al., 2008). Therefore, different heavy mineral assemblages do not necessarily mean that 
they were derived from different source lithologies. They may simply reflect synsedimentary and diagenetic modifications, which need to be considered carefully (e.g., Morton and Hallsworth, 1999 and Morton, 2012). The ultrastable heavy minerals zircon, rutile and tourmaline (Hubert, 1962) are more stable than garnet, which in turn is more stable than staurolite, kyanite, titanite, and epidote under burial diagenetic conditions. Amphibole and pyroxene, for instance, are relatively unstable. The stability of apatite varies, mainly depending on the environment (Pettijohn, 1941, Morton and Hallsworth, 1999 and Morton, 2012). It is therefore important to compare the ratios of minerals with similar hydrodynamic and alteration behaviour when establishing provenance relationships. Single grains can be characterised by their morphology (e.g., roundness), colour, and geochemical characteristics (Morton et al., 2004). One has to consider that the extent of chemical weathering also depends on the climate (e.g., Velbel, 2007 and Andò et al., 2012, and references therein). Garnet is relatively stable during diagenesis, but in hot humid climates, garnet is destroyed faster than hornblende, and grains can be completely transformed into clay coatings (Garzanti et al., 2013). At lower latitudes, dissolution effects also stable minerals such as zircon and tourmaline. Depending on the extension of alteration, specific minerals can show corrosion features and deep etching (e.g., Price et al., 2013). Due to the fact that corrosion morphologies depend on crystal structure, the dissolution features of specific minerals can offer clues about how much the detrital heavy mineral assemblage is modified and therefore about the climate in the stratigraphic record (e.g., Velbel, 2007 and Andò et al., 2012, and references therein).

Morton (1984) proved the stability of garnet grains and found out that garnets persist to depths of about $3000 \mathrm{~m}$ in Tertiary sandstones from the northern North Sea. At greater depths, garnet surfaces become etched and grains show skeletal textures (Turner and Morton, 2007). Walderhaug and Porten (2007) investigated the stability of heavy minerals on the Norwegian continental shelf and found out that the maximum depth and temperature of occurrence for garnet are $\sim 4600 \mathrm{~m}$ and $175^{\circ} \mathrm{C}$, respectively. First signs of garnet dissolution occur at $2000 \mathrm{~m}$ depth, and at $>3500 \mathrm{~m}$ depth garnets are partially dissolved. Under acidic weathering conditions, garnet is considerably less stable than during burial diagenesis (Velbel, 1984). The instability of garnet may therefore cause problems when using this mineral for sedimentary provenance analysis (Haughton and Farrow, 1989). Beyond depletion of garnet, intrastratal solution may also cause major variations in the composition of garnet 
suites. For example, high-Ca garnets are considered less stable than low-Ca garnets during burial and diagenesis (Morton, 1987 and Harangi et al., 2001). It is therefore important to take into account that the stability of garnet depends on its chemical composition.

\section{Discrimination diagrams of garnet}

Garnet composition strongly depends on the paragenesis in the host rock. On an empirical basis, however, there is strong evidence that certain garnet compositions are most likely related to specific source rocks such as high-grade metamafic rocks, granulite-facies metasedimentary rocks, granitoids, and skarn deposits (e.g., Morton et al., 2004, Mange and Morton, 2007 and Aubrecht et al., 2009). Such relations derived from empirical evidence are important in sedimentary provenance analysis because sediment derived from various source areas and geodynamic settings might be mixed, and thus inferences drawn from sediment characteristics alone are inevitably subjected to some degree of uncertainty.

Discrimination of garnet is done in different ways, for example, by using flow charts, binary diagrams or ternary diagrams or a combination of those. In the following, we give a brief outline about the binary and ternary discrimination diagrams commonly used in sedimentary provenance studies.

Wright (1938) made the first attempt to classify garnets from different host rock types in ternary diagrams, as displayed in Fig. 1a. Morton et al. (2004) introduced a ternary diagram using almandine + spessartine, pyrope, and grossular as poles, and the discrimination fields A, B, and C, redefined and detailed in Mange and Morton (2007), as shown in Fig. 1b. This diagram has widely been applied in a number of garnet provenance studies (e.g., Whitham et al., 2004, Morton et al., 2005, Mange and Morton, 2007, Meinhold et al., 2010 and Morton et al., 2011). Aubrecht et al. (2009) presented a new classification scheme for natural garnet using pyrope-almandinegrossular and pyrope-almandine-spessartine ternary diagrams (Fig. 1c, d). The first ternary diagram for garnet classification using a spessartine-pyrope-grossular diagram without involving the Fe-component was developed by Teraoka et al., 1997 and Teraoka et al., 1998 (Fig. 1e) and applied by Win et al. (2007). 

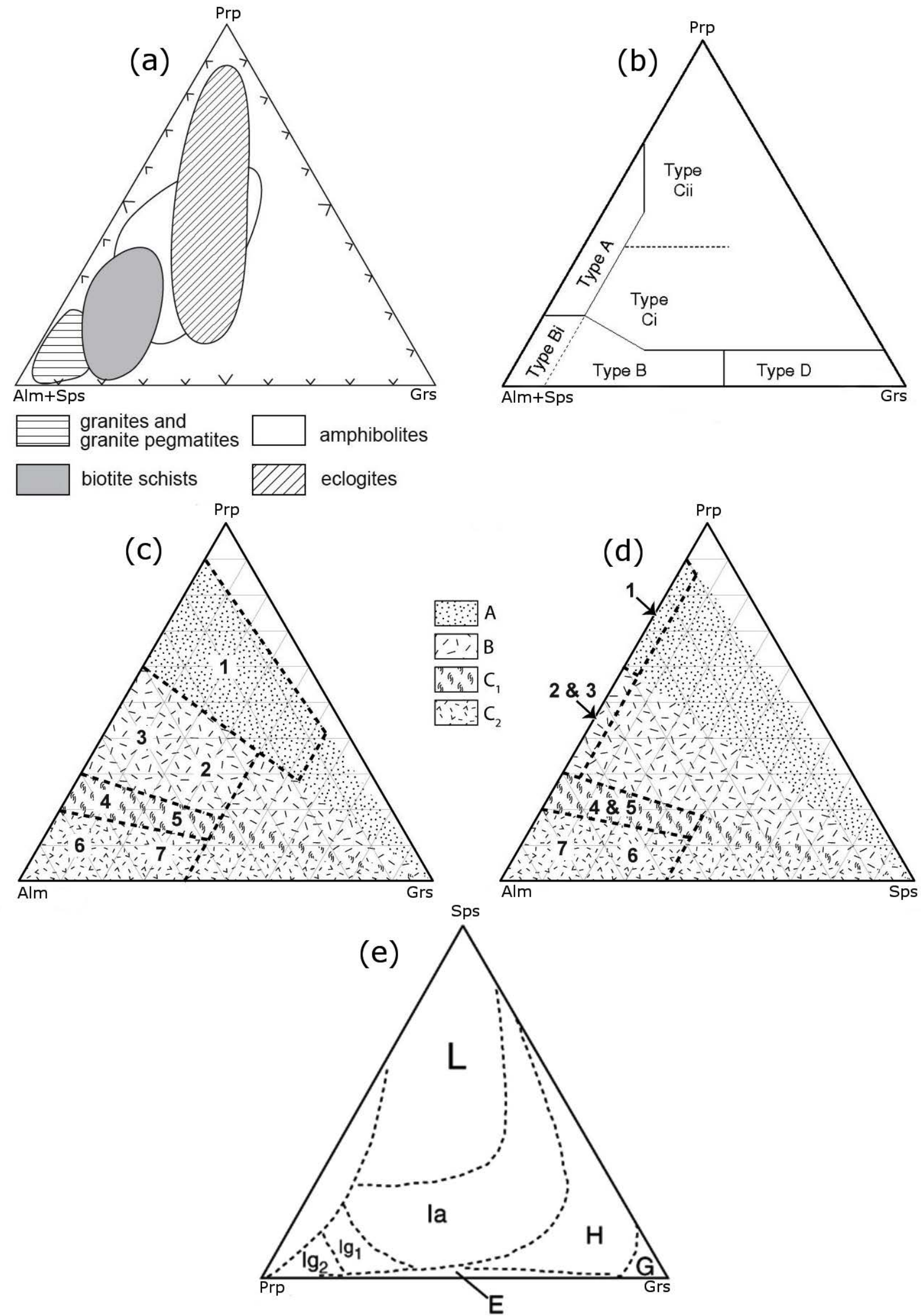

Fig. 1. Ternary diagrams used for garnet discrimination. (a) Ternary discrimination diagram with proportion of pyrope, almandine plus spessartine, and grossular as poles after Wright (1938); (b) Ternary discrimination diagram with molecular proportions of pyrope, almandine plus spessartine, and 
grossular as poles after Mange and Morton (2007). A - mainly from high-grade granulite-facies metasediments or charnockites and intermediate felsic igneous rocks, B - amphibolite-facies metasedimentary rocks, $\mathrm{Bi}$ - intermediate to felsic igneous rocks, $\mathrm{Ci}$ - mainly from high-grade mafic rocks, Cii - ultramafics with high Mg (pyroxenites and peridotites), D - metasomatic rocks, very lowgrade metamafic rocks and ultrahigh temperature metamorphosed calc-silicate granulites; (c) Ternary discrimination diagram with pyrope, almandine, and grossular compositions as poles after Aubrecht et al. (2009). A - garnets from high-pressure (HP) to ultrahigh-pressure (UHP) rocks, B - garnets from eclogite- and granulite-facies rocks, $\mathrm{C}$ - garnets from amphibolite-facies rocks. The group $\mathrm{C}$ is further subdivided into two subgroups. The transitional field $\mathrm{C}_{1}$ includes garnets from higher amphibolite- to granulite-facies rocks whereas the field $\mathrm{C}_{2}$ includes garnets from amphibolite-facies rocks but also includes garnets from many other rocks such as blueschists, skarns, serpentinites and igneous rocks. The source lithologies for garnets are distinguished into 7 groups. 1 - Garnets derived from UHP eclogites or garnet peridotites, 2 - Garnets derived from HP eclogites and HP mafic granulites, 3 Garnets derived from felsic and intermediate granulites, 4 - Garnets derived from gneisses metamorphosed under pressure and temperature conditions transitional to granulite- and amphibolitefacies metamorphism, 5 - Garnets derived from amphibolites metamorphosed under pressure and temperature conditions transitional to granulite- and amphibolite-facies metamorphism, 6 - Garnets derived from gneisses metamorphosed under amphibolite-facies conditions, 7 - Garnets derived from amphibolites metamorphosed under amphibolite-facies conditions. (d) Ternary diagram with pyrope, almandine, and spessartine compositions as poles after Aubrecht et al. (2009). (e) Ternary discrimination diagram with proportions of pyrope, grossular, and spessartine as poles after Teraoka et al. (1997, 1998). L - Low P-T, la - Intermediate P-T (up to amphibolites facies), H - High P-T, $\lg _{1}$, $\mathrm{Ig}_{2}$ - Intermediate P-T (granulite facies), E - Eclogite, G - grandite garnets

Grütter et al. (2004) presented a binary discrimination scheme for mantle-derived garnets on the basis of the $\mathrm{CaO}$ and $\mathrm{Cr}_{2} \mathrm{O}_{3}$ contents in these garnets (Fig. 2). Garnets containing high $\mathrm{Cr}$ contents often have high proportions of pyrope too. These garnets are minor phases in peridotites and may constitute important indicators in diamond exploration. However, this classification scheme is not developed to discriminate a wide range of garnet types, but to categorise the compositions of garnet grains that may be associated with diamond-bearing intrusive rocks. 


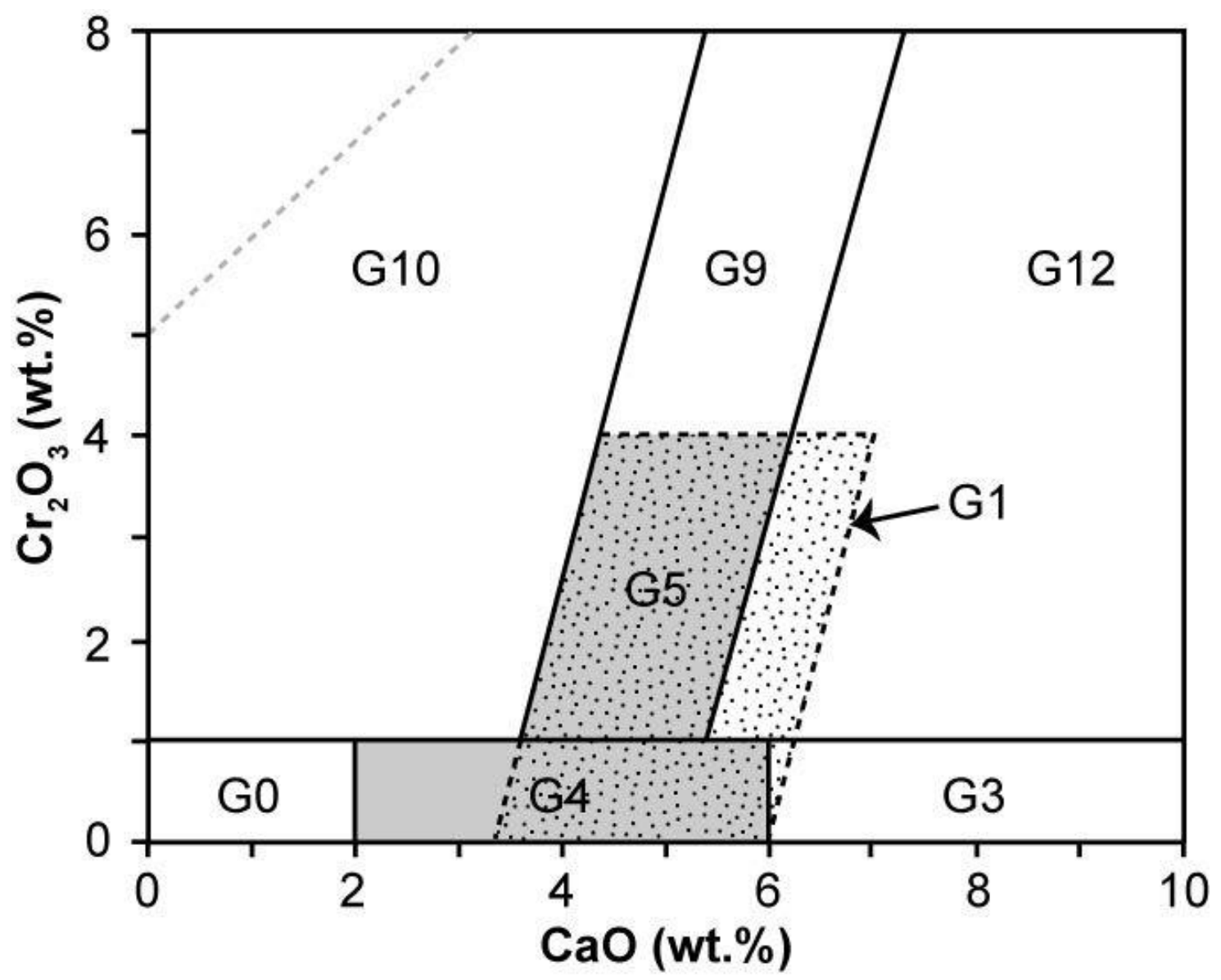

Fig. 2. G-number nomenclature of the classification scheme of Grütter et al. (2004) for mantle-derived garnets viewed in a conventional $\mathrm{Cr}_{2} \mathrm{O}_{3}$ vs. $\mathrm{CaO}$ diagram (after Gütter et al., 2004). G0 Unclassified, G1 - Low-Cr megacryst garnet, G3 - Eclogitic garnet, G4 \& G5 - Pyroxenitic, websteritic and eclogitic garnets, G9 - Lherzolitic garnet, G10 - Harzburgitic garnet, G11 - High- $\mathrm{TiO}_{2}$ peridotitic garnet, G12 - Wehrlitic garnet. Note that the megacryst group G1 (dotted pattern) does not actually overlap groups G3, G4, G5, G9 or G12 since it occurs at higher $\mathrm{TiO}_{2}$ content (see Grütter et al., 2004). Pyroxenitic categories $\mathrm{G} 5$ and $\mathrm{G} 4$ are indicated by grey fields. Group $\mathrm{G} 5$ garnets are separated from G9 garnets by a Mg-number $<0.7$ threshold. See Grütter et al. (2004) for details.

Suggate and Hall (2013) recently presented a new approach of garnet discrimination by using two triangular plots with apices of almandine, pyrope, spessartine, and grossular + andradite + schorlomite (Fig. 3). In their scheme, protoliths of garnets are identified by a stepwise separation of garnets of specific composition. First, garnets with an uncommon content of $\mathrm{Y}_{2} \mathrm{O}_{3}, \mathrm{~V}_{2} \mathrm{O}_{3}$, and $\mathrm{ZrO}_{2}$ are removed. In a second step, garnets with high $\mathrm{TiO}_{2}$ content are separated. Due to that separation, they have a group of garnets derived, for example, from ores, skarns, mafic pyroclastic rocks, and nepheline syenites. In a next step, a group of garnets with high uvarovite and pyrope contents commonly derived from ultramafic rocks is separated. After the separation, the remaining garnets, for example, those from amphibolite-facies, granulite-facies, 
and eclogite-facies rocks, are plotted in two triangular plots. These garnets overlap, but many mafic eclogites can be distinguished by their low spessartine content (Suggate and Hall, 2013).

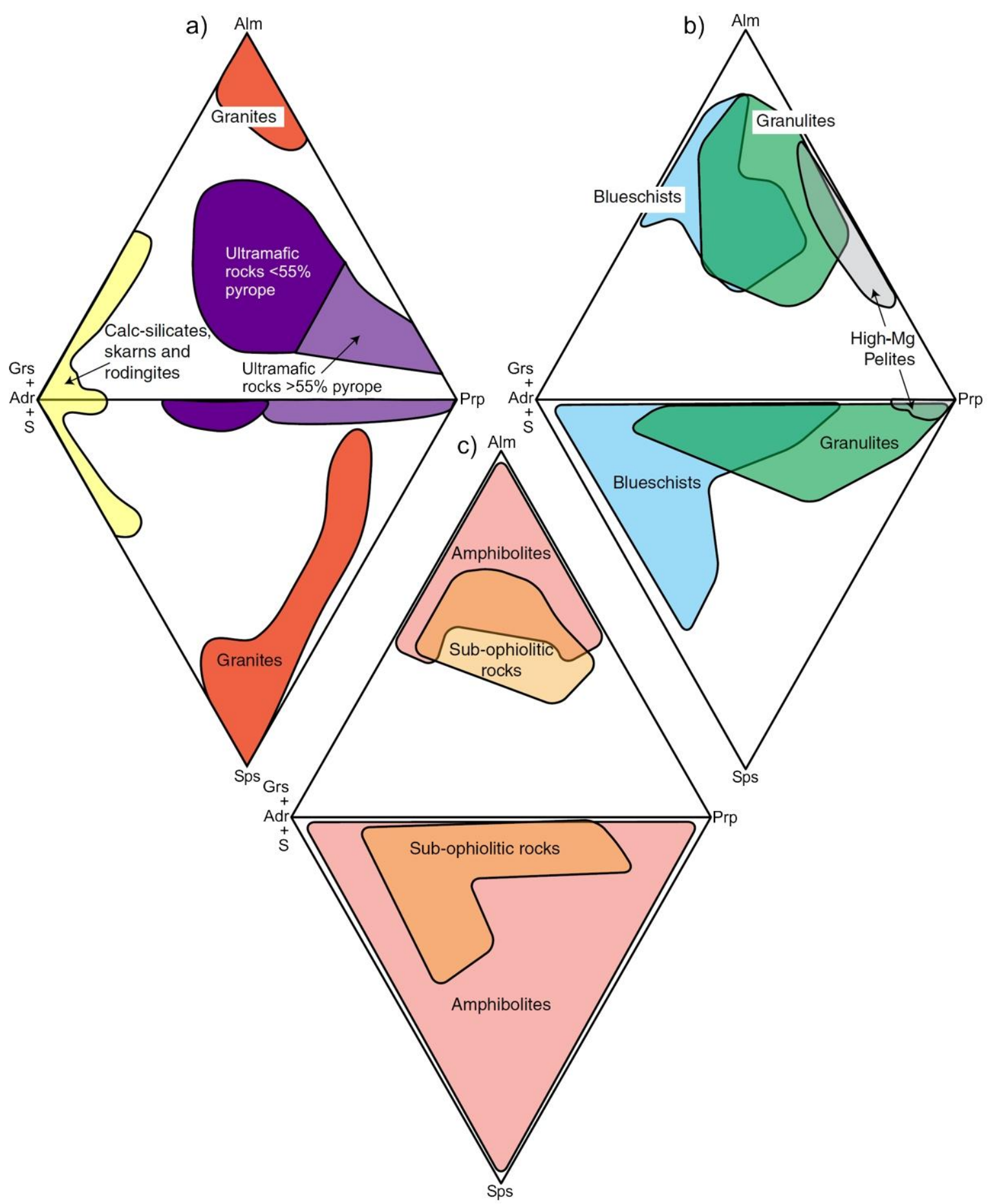

Fig. 3. Ternary plots using end-members grossular+andradite+schorlomite, almandine, pyrope and spessartine showing sub-areas characteristic of garnets with different protoliths of Suggate and Hall, 2013). (a) Ultramafic rocks (peridotites, eclogites and kimberlites), granites, calc-silicates, skarns and rodingites. $95 \%$ of all ultramafic garnets have pyrope contents $>55 \%$. (b) Granulites, granulite-facies high-Mg pelites, and blueschists. (c) Amphibolites and metamafic sub-ophiolitic rocks. 
Chemical discrimination is not only based on major element composition; trace elements are also important to decipher source rock petrology. Trace element zoning is often more extensive than major element zoning (Hickmott et al., 1987, Otamendi et al., 2002 and Jung and Hellebrandt, 2006, and references therein), and is therefore sensitive to chemical and thermobarometric changes (Jung and Hellebrandt, 2006). It provides information about metamorphic processes, in situ migmatisation, metamorphic growth, and igneous crystallisation (Jung and Hellebrandt, 2006).

A possibility to distinguish mantle- from crustal-derived garnets is the oxygen isotope composition and the $\mathrm{H}_{2} \mathrm{O}$ content. For example, the mean $\delta^{18} \mathrm{O}$ value for all garnet megacrysts from Group I kimberlites worldwide is 5.24\%o (Schulze et al., 2001). Relatively low $\mathrm{MgO}$ contents together with a high $\delta^{18} \mathrm{O}$ value suggest formation from a felsic (i.e., crustal) melt (Yuan et al., 2009).

\section{Sample description and method}

\subsection{Samples}

We compiled a large database ( $\mathrm{N}=3532$ single analyses) on major element mineral chemistry of garnet grains derived from metamorphic and igneous rocks from different parts of the world. The data were collected from the literature together with new data acquired from basement rocks in Austria and Norway ( $N=530$; this study). In the database, 982 garnet analyses are from mantle rocks, 599 are from metaigneous eclogites, 281 are from metaigneous granulites, 193 are from metaigneous amphibolites, 775 are from magmatic rocks, and 702 are from metasedimentary rocks. Magmatic rocks are subdivided in plutonic and volcanic and felsic and mafic rocks. Metasedimentary rocks are subdivided in greenschist-facies, amphibolite-facies, granulite-facies, and eclogite-facies metasedimentary rocks (Table 1). 
Table 1. Summary of the type of garnet-bearing rocks and quantity of data considered in this study (see Supplementary data).

\begin{tabular}{|l|c|}
\hline Binary diagram & Quantity \\
\hline Lithology & \\
\hline Low-Cr megacrysts & 454 \\
\hline harzburgites & 12 \\
\hline Iherzolites & 83 \\
\hline pyroxenites & 21 \\
\hline metaigneous eclogites & 565 \\
\hline
\end{tabular}

\begin{tabular}{|l|c|}
\hline Ternary diagrams & Quantity \\
\hline Lithology & \\
\hline ultramafics & 982 \\
\hline metaigneous eclogites & 599 \\
\hline metaigneous amphibolites & 193 \\
\hline metaigneous granulites & 281 \\
\hline greenschist-facies metapelites & 33 \\
\hline amphibolite-facies metapelites & 224 \\
\hline granulite-facies metapelites & 178 \\
\hline eclogite-facies metapelites & 24 \\
\hline felsic plutonic rocks & 499 \\
\hline mafic plutonic rocks & 75 \\
\hline felsic volcanic rocks & 70 \\
\hline mafic volcanic rocks & 131 \\
\hline
\end{tabular}

Our own samples from Austria were collected from the Frosnitz valley area in the central Tauern Window of the Eastern Alps. The Tauern Window exposes exhumed continental basement of European affinity. A nappe stack that developed in a subduction zone during the closure of the Piemont-Liguria and Valais oceans in the Cretaceous and Paleogene represents the Tauern Window (e.g., Schmid et al., 2013). Sample A7-D (geographic coordinates: $47^{\circ} 3^{\prime} 35^{\prime \prime} \mathrm{N}, 12^{\circ} 20^{\prime} 33^{\prime \prime} \mathrm{E}$ ) is a metaigneous eclogite from the Eclogite Zone, which is one of the tectonic units of this nappe stack. Own samples from Norway are from the Western Gneiss Region that comprises Precambrian gneissic basement and allochtonous cover units metamorphosed and deformed during the Caledonian orogeny induced through the collision between Baltica, Laurentia and Avalonia under closure of the lapetus Ocean (e.g., Cuthbert et al., 2000). Samples N5-3 (geographic coordinates: $61^{\circ} 54.855^{\prime} \mathrm{N}$, $5^{\circ} 20.210^{\prime} \mathrm{E}$ ), N16-1 (geographic coordinates: $61^{\circ} 57.281^{\prime} \mathrm{N}, 5^{\circ} 12.562^{\prime} \mathrm{E}$ ) and $\mathrm{N} 4-2$ (geographic coordinates: $61^{\circ} 56.826$ ' $\mathrm{N}, 5^{\circ} 27.937^{\prime} \mathrm{E}$ ) are metaigneous eclogites. Sample N7-1 (geographic coordinates: $61^{\circ} 59.225^{\prime} \mathrm{N}, 5^{\circ} 05.593^{\prime} \mathrm{E}$ ) is a metaigneous 
amphibolite, sample N9-1 (geographic coordinates: $61^{\circ} 56.257^{\prime} \mathrm{N}, 5^{\circ} 08.565^{\prime} \mathrm{E}$ ) is a metaigneous granulite, and sample N24 (geographic coordinates: $62^{\circ} 00.278^{\prime} \mathrm{N}$, $\left.5^{\circ} 36.448 ' \mathrm{E}\right)$ is a peridotite. In the database, our own samples are marked with "Krippner (2013)" and "unpublished". The full database, including the lithology, metamorphic facies, and the full references, referred to in this paper is included in the accompanying Supplementary data (see Appendix A).

\subsection{Analytical details}

Our own samples were analysed with a JEOL JXA 8900 RL electron microprobe equipped with five wavelength dispersive spectrometers at the University of Göttingen (Department of Geochemistry, Geoscience Center). All samples were coated with carbon to ensure conductivity. Measurement conditions included an accelerating voltage of $15 \mathrm{kV}$ and a beam current of $20 \mathrm{nA}$. The counting times were $15 \mathrm{~s}$ for $\mathrm{Si}, \mathrm{Mg}, \mathrm{Ca}, \mathrm{Fe}$, and $\mathrm{Al}$, and $30 \mathrm{~s}$ for $\mathrm{Ti}, \mathrm{Cr}$, and $\mathrm{Mn}$. Matrix correction was performed using ZAF corrections. We analysed the rim, mantle, and the centre for nearly all garnet grains. Measurement conditions are given in Table 2.

Table 2. Operating conditions of the electron microprobe for garnet analyses.Count time on the peak (in s), Bckg time counting time on background position (in s), DL detection limit (in ppm).

\begin{tabular}{|c|c|c|c|c|c|c|c|c|}
\hline Spectrometer & $1 \mathrm{TAP}$ & $1 \mathrm{TAP}$ & 2 TAP & 3 PETJ & 4 PETJ & 4 PETJ & 5 LIFH & 5 LIFH \\
\hline $\begin{array}{l}\text { Element } \\
\text { (Line) }\end{array}$ & $\mathrm{Si}(\mathrm{K} \alpha)$ & $\mathrm{Al}(\mathrm{K} \alpha)$ & $\operatorname{Mg}(\mathrm{K} \alpha)$ & $\mathrm{Ca}(\mathrm{K} \alpha)$ & $\mathrm{Ti}(\mathrm{K} \alpha)$ & $\operatorname{Cr}(\mathrm{K} \alpha)$ & $\operatorname{Mn}(\mathrm{K} \alpha)$ & $\mathrm{Fe}(\mathrm{K} \alpha)$ \\
\hline Count time & 15 & 15 & 15 & 15 & 30 & 30 & 30 & 15 \\
\hline $\begin{array}{l}\text { Bckg time } \\
\text { Standard }\end{array}$ & $\begin{array}{l}5 \\
\text { Garnet, } \\
\text { natural }\end{array}$ & $\begin{array}{l}5 \\
\text { Garnet, } \\
\text { natural }\end{array}$ & $\begin{array}{l}5 \\
\text { MgO, } \\
\text { synthetic }\end{array}$ & $\begin{array}{l}5 \\
\mathrm{CaSiO}_{3} \\
\text { natural }\end{array}$ & $\begin{array}{l}15 \\
\mathrm{TiO}_{2} \text {, } \\
\text { synthetic }\end{array}$ & $\begin{array}{l}15 \\
\mathrm{Cr}_{2} \mathrm{O}_{3} \\
\text { synthetic }\end{array}$ & $\begin{array}{l}15 \\
\text { Rhodonite, } \\
\text { natural }\end{array}$ & $\begin{array}{l}5 \\
\mathrm{Fe}_{2} \mathrm{O}_{3} \\
\text { synthetic }\end{array}$ \\
\hline $\mathrm{DL}$ & 164 & 133 & 115 & 180 & 163 & 179 & 161 & 285 \\
\hline
\end{tabular}

\section{Evaluation of discrimination diagrams}

To our knowledge, no evaluation of the reliability of the various discrimination diagrams discussed in this study has yet been made. We test six commonly applied discrimination diagrams based on major element geochemistry as described above. We place special emphasis on the quality of the data in our database and therefore use only garnet data that could be clearly assigned to a specific rock type. In order to allow a better comparison, the same garnet data are used for all five ternary diagrams. However, not every discrimination diagram aims to differentiate all types of 
garnet-bearing rocks, and hence a subset of the database is used for individual diagrams with more limited application. All analysed garnets, no matter whether the data point is from the rim, the mantle, or the core, are plotted in the individual diagrams, because when we are dealing with detrital garnets this information is often been lost. We commonly do not have the information of the precise location of data points. Our own data are treated in the same way. The precise number of garnets for every rock type is given in Table 1 , and the potential of discriminating garnets for every single diagram is given in Table 3.

\subsection{Ternary discrimination diagrams}

\subsubsection{Wright (1938)}

For the evaluation, 1324 (filled symbols) out of the 3532 grains are tested (Fig. 4). Of these, 599 garnets are from metaigneous eclogites, 193 are from metaigneous amphibolites, 499 are from granites and pegmatites, and 33 are from greenschistfacies metapelites (Table 1). Most of the eclogitic garnets do not plot in their expected field ( 23\% success) (Fig. 4a). Many of the eclogitic garnets plot also in the field for amphibolites and biotite schists (Fig. 4a). Many of the amphibolite derived garnets plot outside the expected field ( 57\% success) (Fig. $4 \mathrm{~b})$. Nearly half of the tested amphibolite garnets also plot in the field for low-grade metamorphic rocks (biotite schists) (Fig. 4b). Because both eclogitic and amphibolitic garnets plot in the field for amphibolitic garnets and garnets derived from biotite schists, a discrimination of these groups is difficult. A clear discrimination of eclogitic from amphibolitic garnets is only possible if the eclogitic garnets have a pyrope content of more than $30 \%$; this is the case for 260 eclogitic garnets out of 599 (43\% success). Only about $51 \%$ of the garnets derived from greenschist-facies metasediments (biotite schists) plot in their expected field; the others mainly plot in the field for garnets derived from granites and pegmatites (Fig. 4c). Garnets from felsic plutonic rocks mostly plot in or nearby their assigned field ( $70 \%$ success) (Fig. $4 \mathrm{~d}$ ), but due to the fact that about half of the garnets derived from metasedimentary rocks also plot in the field for garnets derived from granites and granite pegmatites, these garnets cannot be discriminated from each other. 

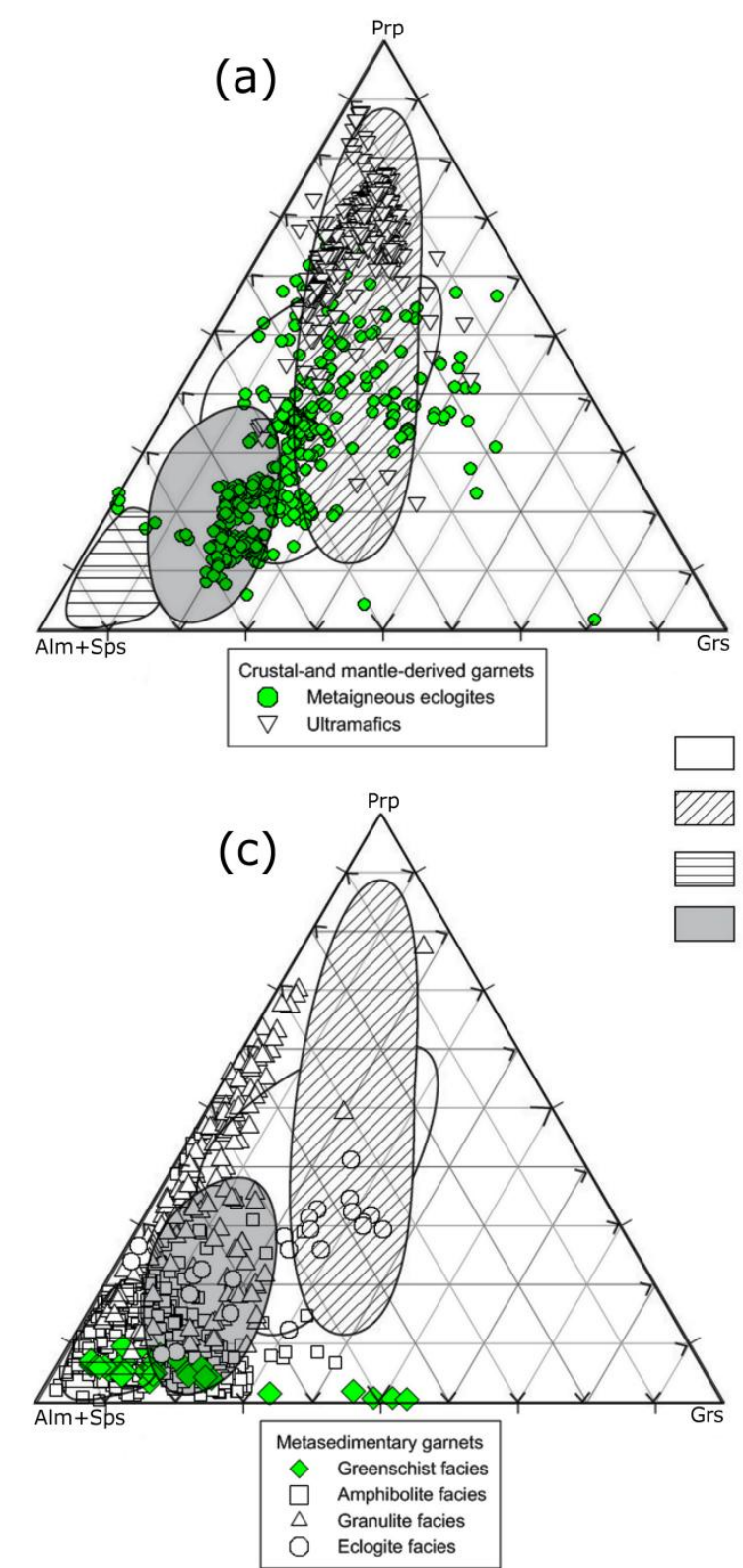

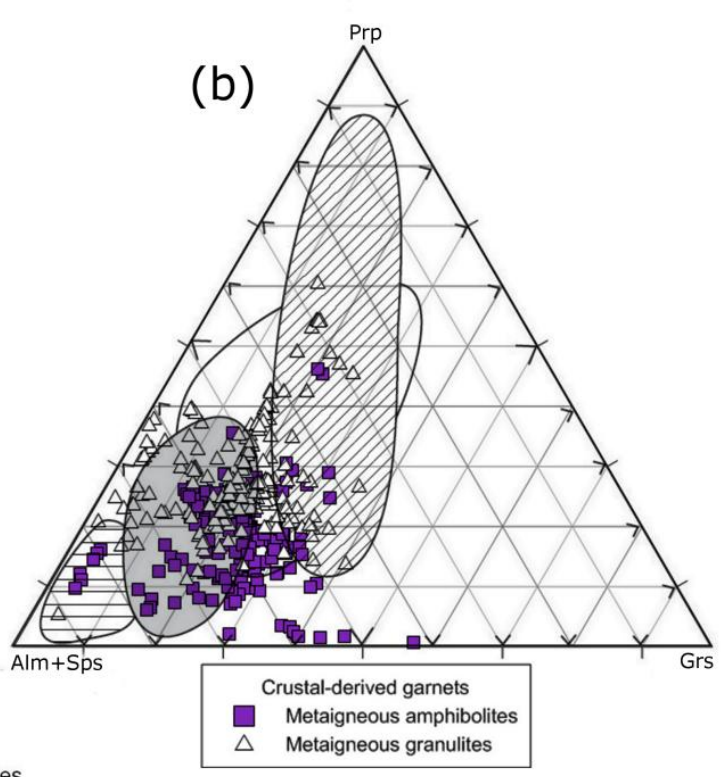

amphibolites eclogites granites and granite pegmatites biotite schists (d)

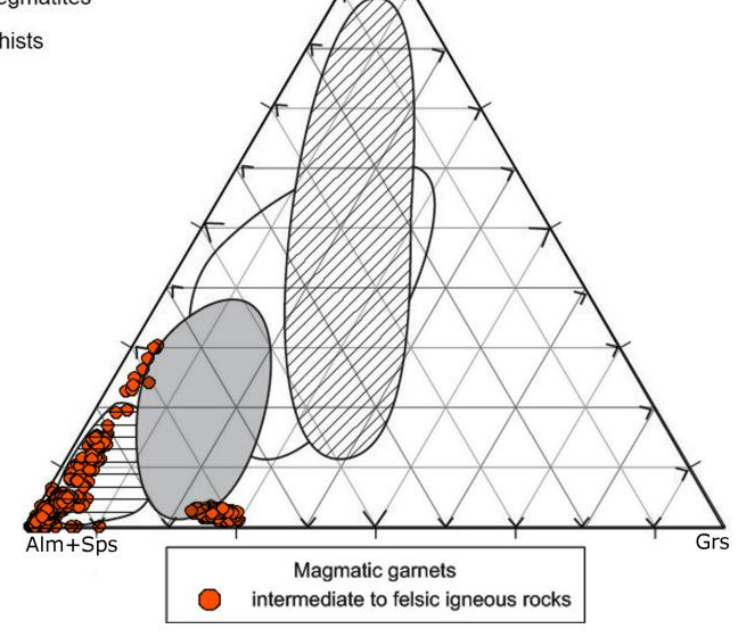

Fig. 4. Evaluation of the classification scheme of Wright (1938) using the database compiled in this study. (a) Crustal- and mantle-derived garnets. (b) Crustal-derived garnets. (c) Metasedimentary garnets. (d) Magmatic garnets. Filled symbols - included in the valuation; Open symbols - not included in the valuation because of the lack of discrimination fields for these garnets.

\subsubsection{Mange and Morton (2007)}

The diagram of Mange and Morton (2007) (Fig. 5) is a modification of the diagram proposed by Morton et al. (2004) on the basis of garnet compositions in Scottish and Norwegian river sediments. For the evaluation, 2956 (filled symbols) out of the 3532 grains are tested. Of these, 982 garnets are from ultramafic rocks, 599 garnets are from metaigneous eclogites, 193 are from metaigneous amphibolites, 281 are from 
metaigneous granulites, 499 are from granites and pegmatites, 224 are from amphibolite-facies metapelites, and 178 are from granulite-facies metapelites (Table 1). All mantle-derived garnet grains plot in the expected field Cii for ultramafic rocks, except for eight analyses ( 99\% success) (Fig. 5a). Garnets from eclogites usually should plot in the fields $\mathrm{Cii}$ and $\mathrm{Ci}$ (high-grade metamafic rocks). Approximately $7 \%$ of garnets derived from eclogites plot outside their field (Fig. 5a). Most of the garnets derived from metaigneous amphibolites and granulites plot in the expected field for high-grade mafic rocks (field $\mathrm{Ci}$; 81\% success), however, they cannot be discriminated from garnets derived from eclogites, because these garnets also plot in field Ci (Fig. 5b). Only mantle-derived garnets with a pyrope content $>40 \%$ can be clearly discriminated from crustal-derived garnets ( $97 \%$ success) (Fig. 5a). Garnets derived from metasedimentary rocks mainly plot in fields $A, B$, and $\mathrm{Bi}$ (Fig. 5c). Of amphibolite-facies metasedimentary garnets, 224 out of 467 plot outside their respective field (field $B ; \sim 52 \%$ success), and 56 out of 178 granulitefacies metasedimentary garnets plot outside their expected field (field $A ; \sim 68 \%$ success). Garnets of granulite-facies metasediments $(n=39)$ with a pyrope content $>44 \%$ can be clearly discriminated from the group of amphibolite-facies metasedimentary garnets (Fig. 5c). Intermediate to felsic igneous garnets should plot in fields $\mathrm{A}$ and $\mathrm{Bi}$, which is the case for $72 \%$ of the samples. Those garnets plotting in field A (2\%), however, cannot be discriminated from high-grade metasedimentary garnets. Moreover, some of the igneous garnets also plot in field B (Fig. 5d) and cannot be discriminated from amphibolite-facies metasedimentary garnets. Because many of the amphibolite-facies metasedimentary garnets plot in field $\mathrm{Bi}$, a discrimination of metasedimentary and igneous garnets is not possible. 

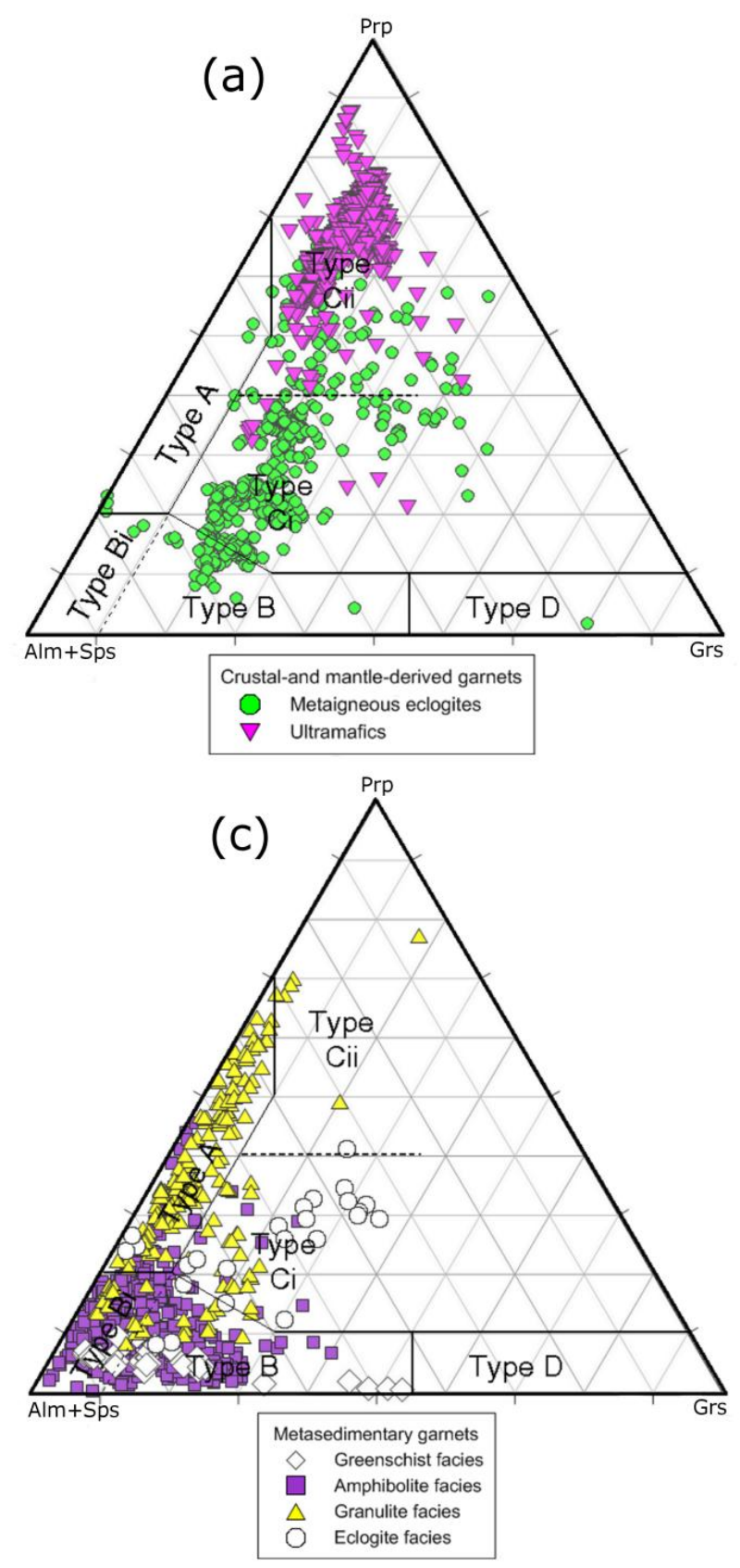
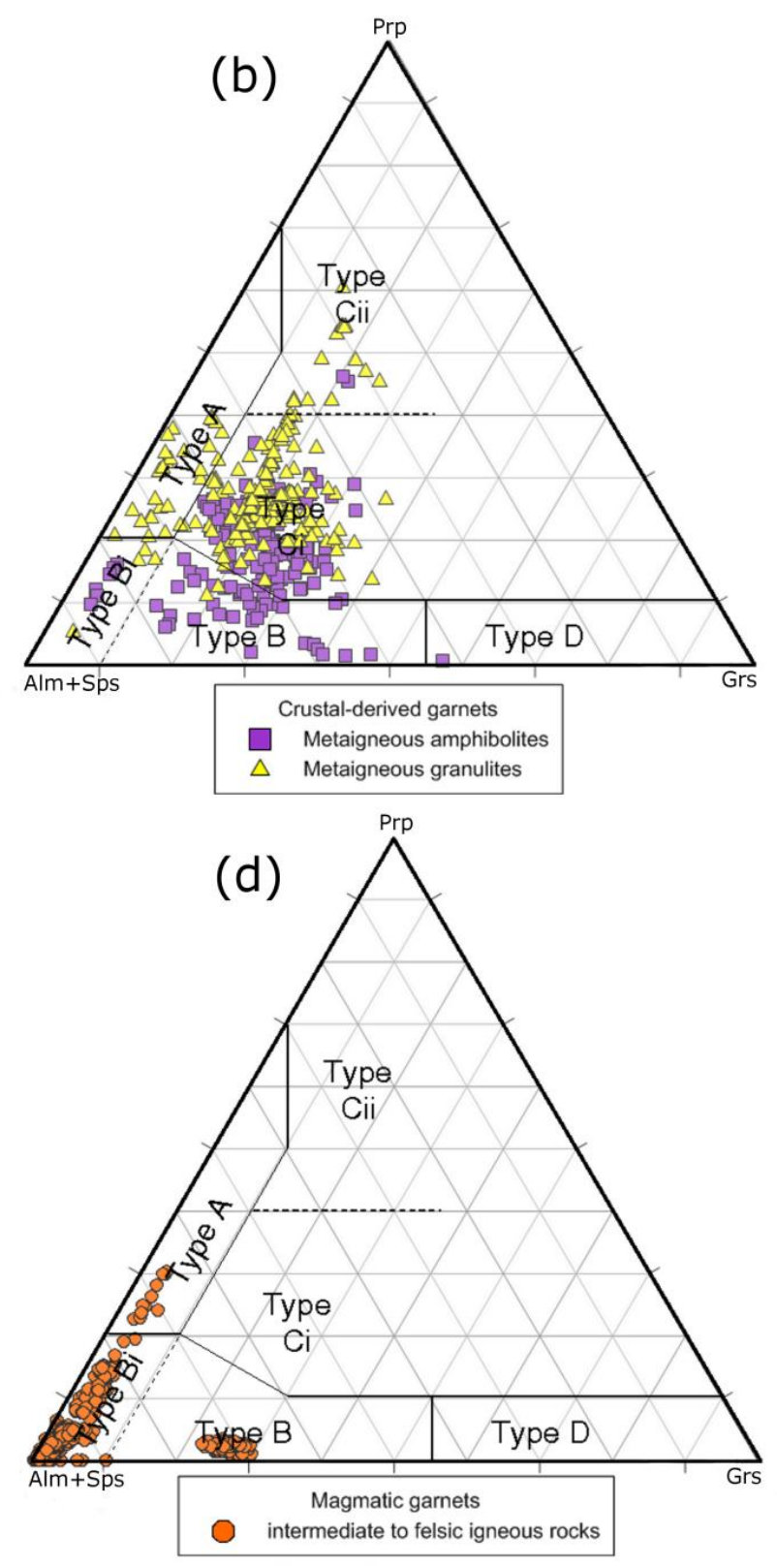

Fig. 5. Evaluation of the classification scheme of Mange and Morton (2007) using the database compiled in this study. (a) Crustal- and mantle-derived garnets. (b) Crustal-derived garnets. (c) Metasedimentary garnets. (d) Magmatic garnets. A - mainly from high-grade granulite-facies metasediments or charnockites and intermediate felsic igneous rocks, B - amphibolite-facies metasedimentary rocks, $\mathrm{Bi}$ - intermediate to felsic igneous rocks, $\mathrm{Ci}$ - mainly from high-grade mafic rocks, Cii - ultramafics with high Mg (pyroxenites and peridotites), D - metasomatic rocks, very lowgrade metamafic rocks and ultrahigh temperature metamorphosed calc-silicate granulites. Filled symbols - included in the valuation; Open symbols - not included in the valuation because of the lack of discrimination fields for these garnets. 


\subsubsection{Aubrecht et al. (2009)}

For the evaluation, 2956 (filled symbols) out of the 3532 grains are tested; i.e. the same as for the diagram by Mange and Morton (2007). Of these, 982 garnets are from ultramafic rocks, 599 garnets are from metaigneous eclogites, 193 are from metaigneous amphibolites, 281 are from metaigneous granulites, 499 are from granites and pegmatites, 224 are from amphibolite-facies metapelites, and 178 are from granulite-facies metapelites (Table 1). In both diagrams from Aubrecht et al. (2009) (Figs. 6a, 7a), almost all ultramafic garnets plot in the expected field of garnets derived from UHP eclogites or garnet peridotites ( 98\% success). A discrimination of mantle-derived garnets (i.e., those from mantle-derived eclogites and peridotites) from crustal-derived garnets is possible. Only about half of the garnets derived from eclogites plot in the expected field ( $55 \%$ success). Many of them also plot in fields 4 to 7 (Figs. 6a, 7a), i.e. these cannot be discriminated from garnets derived from metaigneous granulites and amphibolites.

Most of the granulite- and amphibolite-derived garnets plot in the expected field. About $8 \%$ of the garnets derived from granulites and $\sim 6 \%$ of amphibolite-derived garnets plot outside their field (Figs. 6b, 7b). However, a clear discrimination of garnets derived from eclogites, granulites, and amphibolites is rather difficult. It is possible to discriminate mantle-derived garnets from crustal-derived garnets, as done in the diagram of Mange and Morton (2007). In Figs. 6c, 7c, garnets derived from amphibolite-facies metasediments are expected to plot in fields 4 to 7 . About $4 \%$ of garnets for the first diagram of Aubrecht et al. (2009) (Fig. 6c) and $~ 7 \%$ of garnets for the second diagram of Aubrecht et al. (2009) (Fig. 7c) plot outside their field. About $22 \%$ of the garnets derived from granulite-facies metasediments plot outside their field (Figs. 6c, 7c). According to the diagram of Aubrecht et al. (2009), igneous garnets should appear in field $\mathrm{C}_{2}$, which is the case for the most felsic plutonic garnets (Figs. 6d, 7d). Only $\sim 3 \%$ of the igneous garnets plot outside their field (Figs. 6d, 7d), but due to the fact that in this field also garnets from gneisses and amphibolites metamorphosed under amphibolite-facies conditions are located, a discrimination of these groups is not possible. 

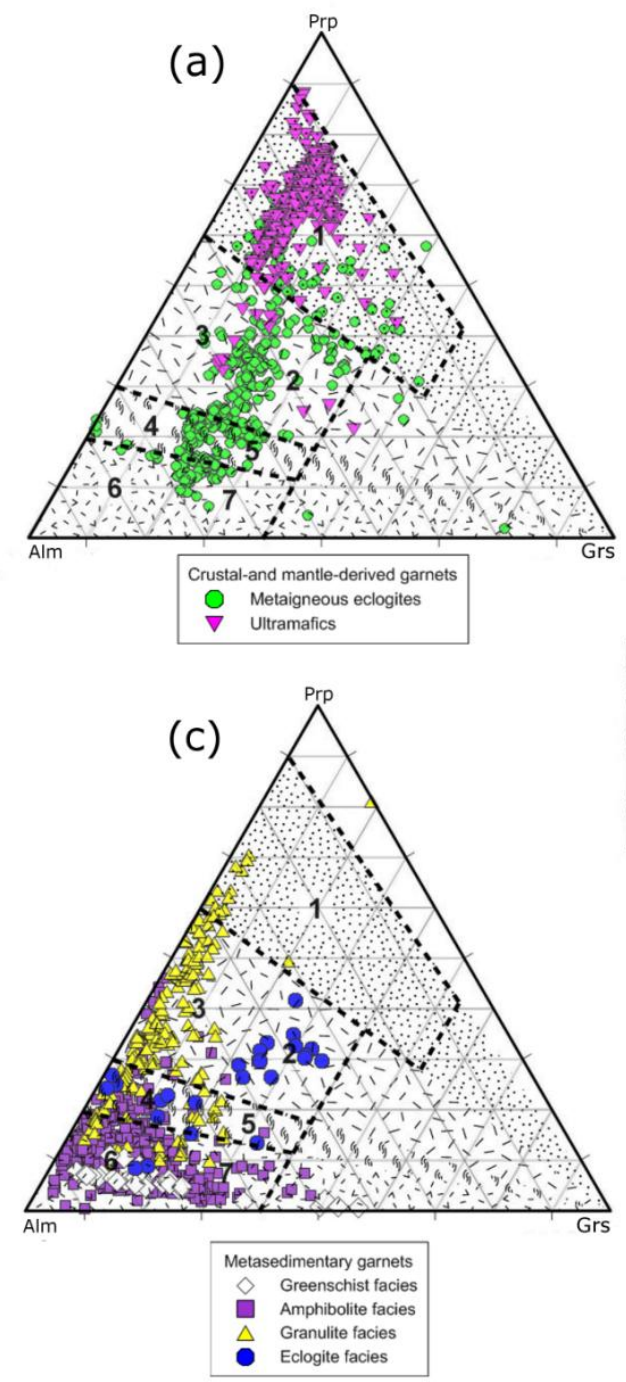

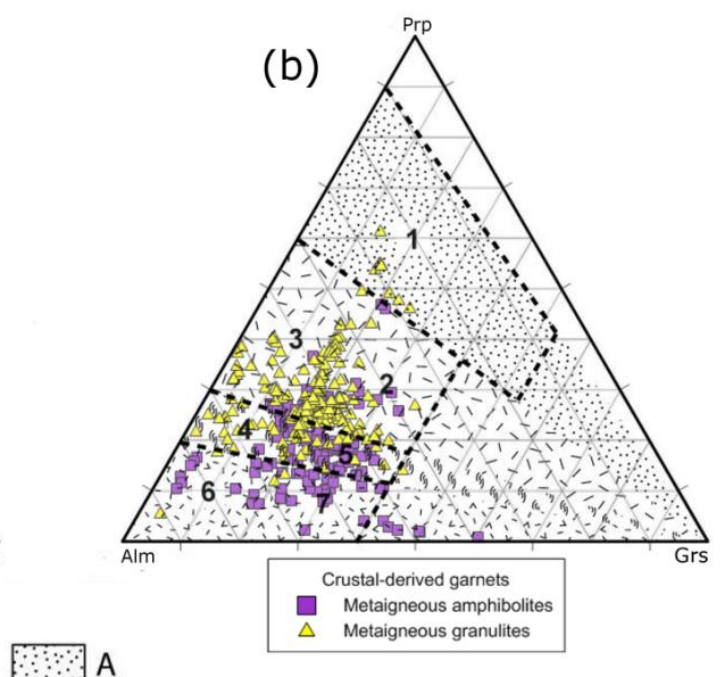

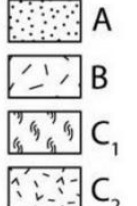

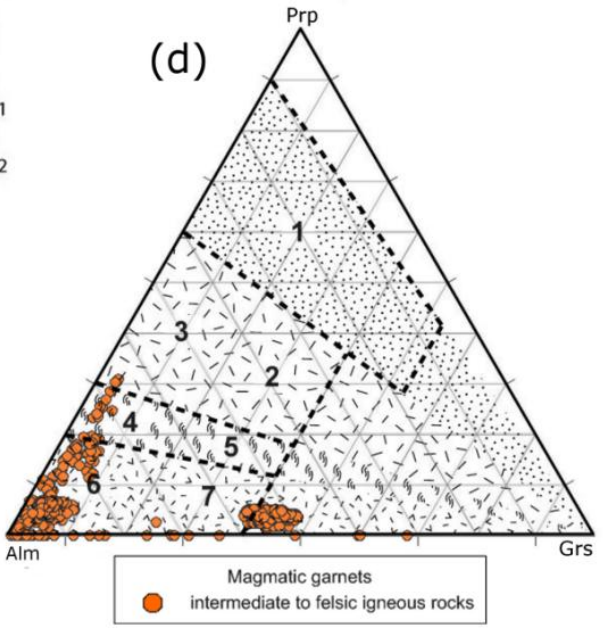

Fig. 6. Evaluation of the first classification scheme of Aubrecht et al. (2009) using the database compiled in this study. (a) Crustal- and mantle-derived garnets. (b) Crustal-derived garnets. (c) Metasedimentary garnets. (d) Magmatic garnets. A - garnets from high-pressure (HP) to ultrahighpressure (UHP) rocks, B - garnets from eclogite- and granulite-facies rocks, C - garnets from amphibolite-facies rocks. The group $C$ is further subdivided into two subgroups. The transitional field $C_{1}$ includes garnets from higher amphibolite- to granulite-facies rocks whereas the field $C_{2}$ includes garnets from amphibolite-facies rocks but also includes garnets from many other rocks such as blueschists, skarns, serpentinites and igneous rocks. The source lithologies for garnets are distinguished into 7 groups: 1 - Garnets derived from UHP eclogites or garnet peridotites, 2 - Garnets derived from HP eclogites and HP mafic granulites, 3 - Garnets derived from felsic and intermediate granulites, 4 - Garnets derived from gneisses metamorphosed under pressure and temperature conditions transitional to granulite- and amphibolite-facies metamorphism, 5 - Garnets derived from amphibolites metamorphosed under pressure and temperature conditions transitional to granulite- and amphibolite-facies metamorphism, 6 - Garnets derived from gneisses metamorphosed under amphibolite-facies conditions, 7 - Garnets derived from amphibolites metamorphosed under amphibolite-facies conditions. Filled symbols - included in the valuation; Open symbols - not included in the valuation because of the lack of discrimination fields for these garnets. 

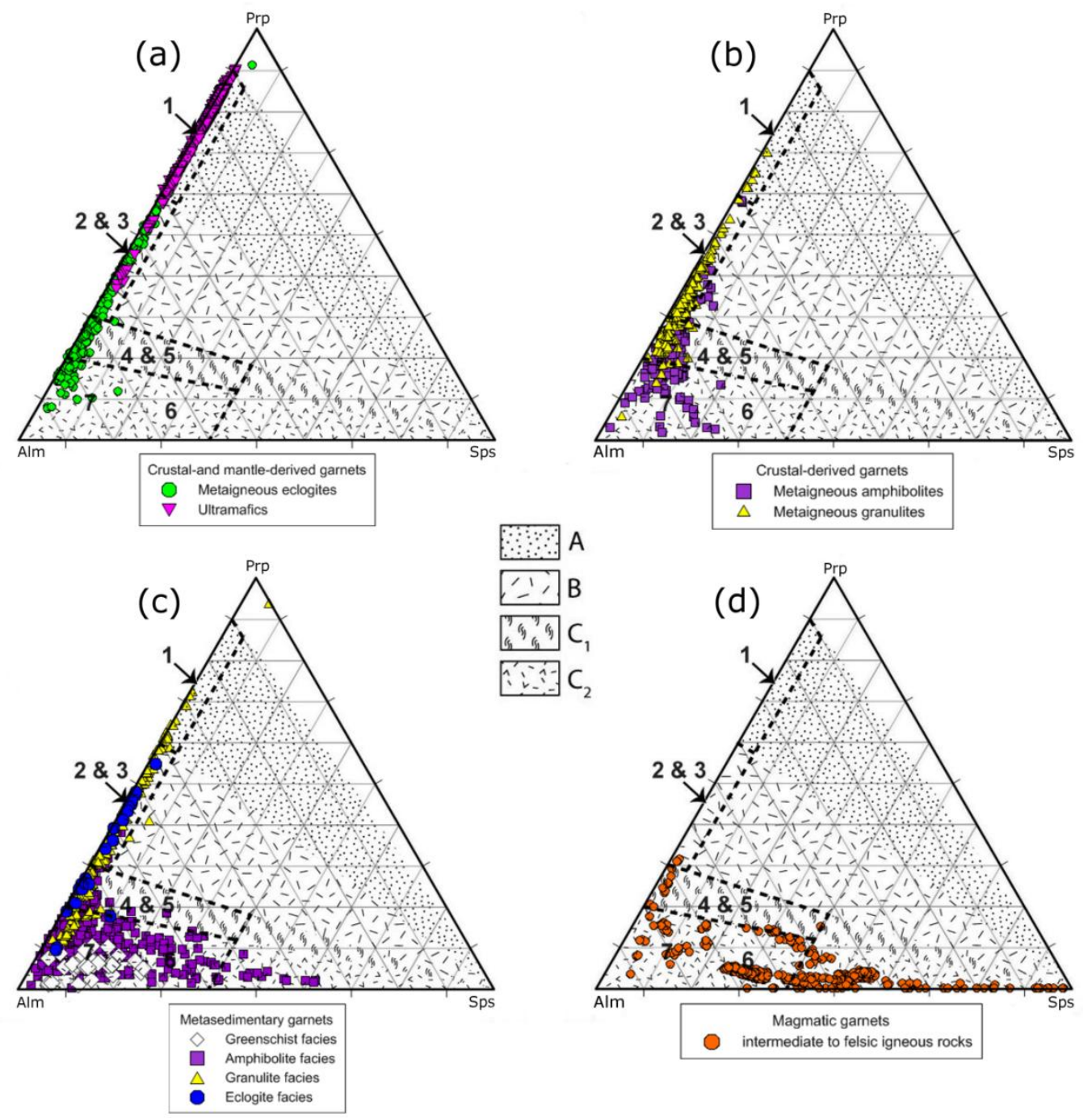

Fig. 7. Evaluation of the second classification scheme of Aubrecht et al. (2009) using the database compiled in this study. (a) Crustal- and mantle-derived garnets. (b) Crustal-derived garnets. (c) Metasedimentary garnets. (d) Magmatic garnets. A - garnets from high-pressure (HP) to ultrahighpressure (UHP) rocks, B - garnets from eclogite- and granulite-facies rocks, C - garnets from amphibolite-facies rocks. The group $C$ is further subdivided into two subgroups. The transitional field $C_{1}$ includes garnets from higher amphibolite- to granulite-facies rocks whereas the field $C_{2}$ includes garnets from amphibolite-facies rocks but also includes garnets from many other rocks such as blueschists, skarns, serpentinites and igneous rocks. The source lithologies for garnets are distinguished into 7 groups: 1 - Garnets derived from UHP eclogites or garnet peridotites, 2 - Garnets derived from HP eclogites and HP mafic granulites, 3 - Garnets derived from felsic and intermediate granulites, 4 - Garnets derived from gneisses metamorphosed under pressure and temperature conditions transitional to granulite- and amphibolite-facies metamorphism, 5 - Garnets derived from amphibolites metamorphosed under pressure and temperature conditions transitional to granulite- and amphibolite-facies metamorphism, 6 - Garnets derived from gneisses metamorphosed under amphibolite-facies conditions, 7 - Garnets derived from amphibolites metamorphosed under amphibolite-facies conditions. Filled symbols - included in the valuation; Open symbols - not included in the valuation because of the lack of discrimination fields for these garnets. 


\subsubsection{Teraoka et al. (1998)}

For the evaluation, 1532 (filled symbols) out of the 3532 grains are tested. Of these, 599 garnets are from metaigneous eclogites, 193 are from metaigneous amphibolites, 281 are from metaigneous granulites, 33 are from greenschist-facies metapelites, 224 are from amphibolite-facies metapelites, 178 are from granulitefacies metapelites, and 24 are from eclogite-facies metasedimentary garnets (Table 1). Garnets derived from eclogites usually should plot in fields $E$ and $\mathrm{H}$. Here, these garnets also plot in field la. Generally, garnets plotting in the la field are of lower metamorphic facies than eclogite facies. Approximately $13 \%$ of the garnets derived from eclogites plot outside their field (Fig. 8a). In the second plot (Fig. 8b), garnets that experienced amphibolite-facies metamorphism should be found in fields la and $\mathrm{H}$. Of those, 38 garnet grains plot outside these fields ( $80 \%$ success). Granulite-derived garnets are commonly found in fields $\lg _{1}$ and $\lg _{2}$. Only 40 grains plot in their expected fields ( 14\% success). A discrimination of garnets derived from eclogites, granulites, and amphibolites is not possible. In this diagram, a discrimination of garnets derived from peridotites and garnets derived from granulites is also not possible, because both groups plot in fields $\lg _{1}$ and $\lg _{2}$ (Fig. $8 a, b$ ). Most of the garnets derived from granulites also plot in the eclogitic field and some in field la (Fig. 8b). In the third plot, garnets derived from metasedimentary rocks show a widespread distribution, especially garnets from amphibolite-facies metasedimentary rocks. Approximately $15 \%$ of garnets from greenschist-facies metasediments, $\sim 31 \%$ of garnets derived from amphibolite-facies metasediments, $\sim 17 \%$ of garnets from granulite-facies metasediments, and $\sim 29 \%$ of the eclogite-facies metasedimentary garnets plot outside their expected fields (Fig. 8c). A general discrimination of these groups is not possible; a discrimination of metasedimentary and metaigneous garnets is also not possible. Intermediate felsic igneous garnets show a very widespread distribution and show much overlap with garnets derived from metasedimentary rocks that suffered amphibolite-facies conditions. Some of them also plot in the field for granulite-facies conditions (Fig. 8c). Altogether, a discrimination of garnets derived from different rocks using the diagram of Teraoka et al., 1997 and Teraoka et al., 1998 is difficult. A small group of garnets derived from magmatic rocks with a low pyrope and low grossular content (both $<10 \%$ in SpsPrp-Grs space) can be discriminated from other garnets. 

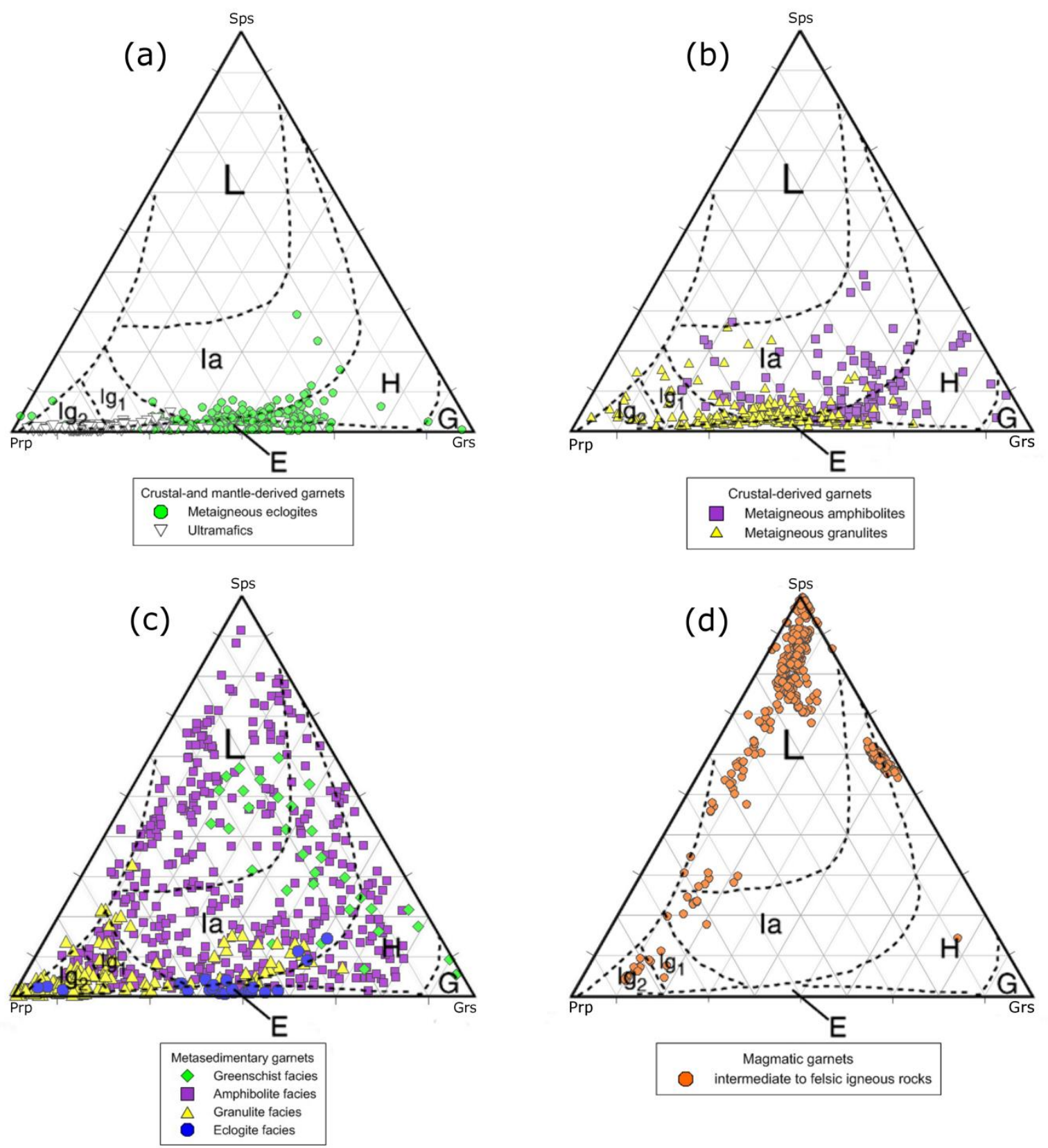

Fig. 8. Evaluation of the classification scheme of Teraoka et al. $(1997,1998)$ using the database compiled in this study. (a) Crustal- and mantle-derived garnets. (b) Crustal-derived garnets. (c) Metasedimentary garnets. (d) Magmatic garnets. L - Low P-T, la - Intermediate P-T (up to amphibolites facies), H - High P-T, $\lg _{1}$, $\lg _{2}$ - Intermediate P-T (granulite facies), E - Eclogite, G grandite garnets. Filled symbols - included in the valuation; Open symbols - not included in the valuation because of the lack of discrimination fields for these garnets.

\subsection{Binary discrimination diagram}

In the $\mathrm{CaO}-\mathrm{Cr}_{2} \mathrm{O}_{3}$ binary plot, eclogitic garnet data with $>12 \mathrm{wt} . \% \mathrm{CaO}$ and mantlederived garnet data with $>11 \mathrm{wt} . \% \mathrm{Cr}_{2} \mathrm{O}_{3}$ are not considered because of the limited size of the diagram (Fig. 9). The $\mathrm{CaO}$ content of eclogitic garnet can be up to 
$32 \mathrm{wt} . \%$, and the $\mathrm{Cr}_{2} \mathrm{O}_{3}$ content of peridotitic garnet can be up to $22 \mathrm{wt.} \%$ (see Grütter et al., 2004). In the diagram of Grütter et al. (2004), 1135 garnets derived from mantle rocks and eclogitic garnets are tested. Of these, 454 garnets are from low-Cr megacrysts, 12 are from harzburgites, 83 are from Iherzolites, 565 are from metaigneous eclogites, and 21 are from pyroxenites (Table 1). Only nine garnets of the low-Cr megacryst garnet suite do not plot in their respective field, but in the field for garnets derived from Iherzolites ( 98\% success). Low-Cr megacrystic garnet (field G1) can be distinguished from pyroxenitic garnet by its $\mathrm{Ti}$ content, because pyroxenitic garnets generally have lower $\mathrm{Ti}$ contents (Grütter et al., 2004) (see Supplementary data). Of garnets derived from low-Cr megacrysts, 27 out of 454 grains cannot be discriminated from G5 garnets (garnets derived from pyroxenites and eclogites) ( 94\% success). Altogether 38 garnet grains derived from low- $\mathrm{Cr}$ megacrysts cannot be discriminated ( 91\% success). Of garnets of the harzburgitic garnet suite, 5 garnet grains ( $\sim 58 \%$ success) and 28 garnet grains of the Iherzolitic garnet suite plot outside the field ( $66 \%$ success). All 565 eclogitic garnets plot in the expected fields $\mathrm{G} 3, \mathrm{G} 4$, and $\mathrm{G} 5$, except for one. However, 39 grains plot in fields G4 and G5, which may indicate pyroxenite origin as well. That means that only garnets from eclogites in field G3 $(\sim 93 \%)$ are fully discriminated in this diagram. Six garnet grains derived from pyroxenites plot outside the field ( $71 \%$ success). Discrimination from eclogitic garnets is not possible (Fig.9). The geochemical parameters $\mathrm{Cr}_{2} \mathrm{O}_{3}$ and $\mathrm{CaO}$ are well chosen in the diagram of Grütter et al. (2004), but significant overlap exists in fields G4/G5. Besides, many of the harzburgitic and Iherzolitic garnets plot outside their respective fields (Fig. 9). 


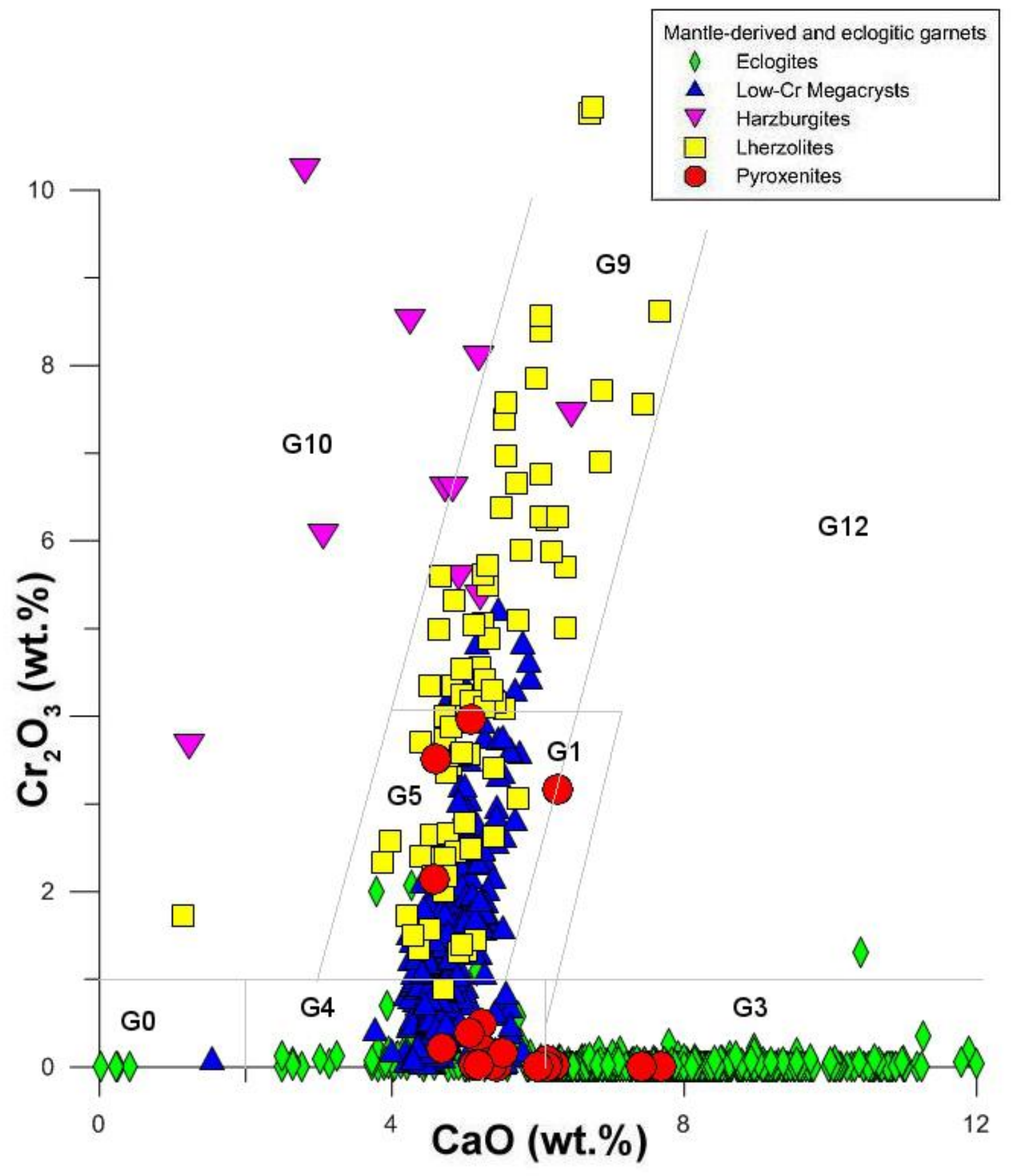

Fig. 9. Evaluation of the classification scheme of Grütter et al. (2004) using the database compiled in this study. G0 - Unclassified, G1 - Low-Cr megacryst garnet, G3 - Eclogitic garnet, G4 \& G5 Pyroxenitic, websteritic and eclogitic garnets, G9 - Lherzolitic garnet, G10 - Harzburgitic garnet, G11 - High- $\mathrm{TiO}_{2}$ peridotitic garnet, G12 - Wehrlitic garnet. Note that the megacryst group G1 (dotted pattern) does not actually overlap groups G3, G4, G5, G9 or G12 since it occurs at higher $\mathrm{TiO}_{2}$ content (see Grütter et al., 2004). Pyroxenitic categories G5 and G4 are indicated by grey fields. Group G5 garnets are separated from G9 garnets by a Mg-number $<0.7$ threshold. See Grütter et al. (2004) for details. 


\section{Multivariate statistical approach}

\subsection{Compositional biplot analysis}

Biplots are performed using "compositions", an open source software package based on R (van den Boogaart and Tolosana-Delgado, 2008). Compositional data analysis is based on log ratios following the methodology proposed by Aitchison (1986). Because the numbers of the dataset are proportions of some whole, they are considered as so-called closed data or compositional data, i.e. the variables sum up to a constant (in our case 100\%) and are thus not independent from each other. This kind of sample space is called a simplex. Before applying usual statistical techniques to compositional data, they have to be transformed from the simplex to the unconstrained multivariate real space through log-ratio transformation (for further readings see Aitchison and Egozcue, 2005 and Pawlowsky-Glahn and Egozcue, 2006).

In this study, the mineral chemical data were normalised to $100 \mathrm{wt} . \%$ and transformed into clr (centred log-ratio) coordinates according to the methodology of Aitchison (1986). The clr transformation enables a symmetrical treatment of all parts of a composition. The biplot is an optimal representation of variability in two dimensions based on principal components where both the data and the variables are represented (Gabriel, 1971). The biplot has been adapted to compositional data by Aitchison (1990) where it enables graphical display of relative variation of a multivariate data set projected onto a plane fixed by principal components. Biplots serve as a valuable tool for estimating the potential for discrimination of a multivariate data set and its subsets (e.g., von Eynatten et al., 2003).

\subsection{Biplot analysis}

In Fig. 10, the major elements $\mathrm{SiO}_{2}, \mathrm{Al}_{2} \mathrm{O}_{3}, \mathrm{FeO}, \mathrm{MgO}, \mathrm{MnO}$, and $\mathrm{CaO}$ are used to differentiate the garnets derived from different kinds of rocks. We choose two biplots defined by the first and second (left side) and by the first and third (right side) principal components. These three components explain approximately $99 \%$ of the total variability. In Fig. 10a all samples are used, in Fig. 10b only igneous rocks and in Fig. $10 \mathrm{c}$ only metapelitic rocks are used. $\mathrm{SiO}_{2}$ and $\mathrm{Al}_{2} \mathrm{O}_{3}$ show the lowest variation in all six sample sets. The small distance between $\mathrm{SiO}_{2}$ and $\mathrm{Al}_{2} \mathrm{O}_{3}$ indicates a relatively constant $\mathrm{SiO}_{2} / \mathrm{Al}_{2} \mathrm{O}_{3}$ value. For the left side of all three sample sets, the major element data show a comparably high variability for $\mathrm{CaO}, \mathrm{MnO}$, and $\mathrm{MgO}$ 
(spread in different directions) and a relatively low variability for FeO. For the right side of all three sample sets, the variability pattern is different. The major element data show the highest variability for $\mathrm{FeO}$, which dominates the third principal component in all three sample sets. In Fig. 10a (right side), $\mathrm{CaO}, \mathrm{MgO}$, and $\mathrm{MnO}$ show similarly low variation in contrast to $\mathrm{FeO}$. In Fig. 10b (right side), $\mathrm{MnO}$ and $\mathrm{MgO}$ show high variability and $\mathrm{CaO}$ rather low variability in contrast to $\mathrm{FeO}$. A trend towards higher $\mathrm{MgO} / \mathrm{MnO}$ values with higher metamorphic grade (eclogite, granulite) is visible, which is also evident in the ternary diagrams (e.g., Wright, 1938, Mange and Morton, 2007 and Aubrecht et al., 2009). Granulite derived garnets accumulate in the centre of the diagram, and the eclogite derived garnets tend towards $\mathrm{MgO}$ and FeO. In Fig. 10c (right side), MgO show a relatively high variability, MnO rather moderate, and $\mathrm{CaO}$ low variability in contrast to $\mathrm{FeO}$. Although there is some overlap, Fig. 10b and c reveals strong potential to separate certain garnet groups on a probabilistic base. However, the biplots demonstrate that garnets derived from amphibolite-facies rocks and garnets derived from greenschist-facies rocks likely remain undistinguishable. With regard to discrimination, the biplots demonstrate that there are clusters of garnet grains belonging to a given garnet-bearing rock. In general, a differentiation of felsic plutonic garnets, metasedimentary, metaigneous, and ultramafic garnets is possible, although there is some overlap. 

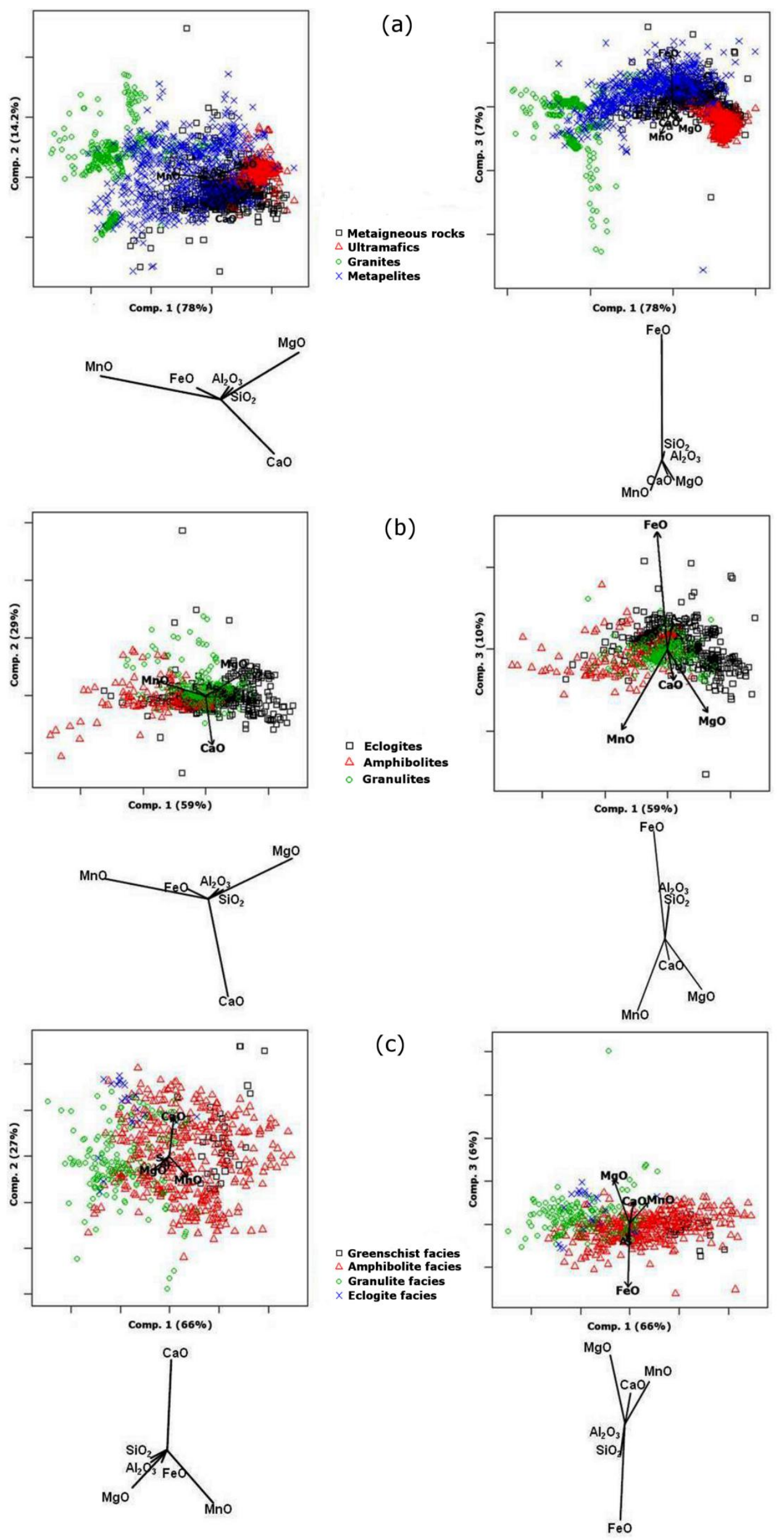
Fig. 10. Biplots of garnet grains from different rocks for five major elements $\left(\mathrm{SiO}_{2}, \mathrm{Al}_{2} \mathrm{O}_{3}, \mathrm{FeO}, \mathrm{CaO}\right.$, $\mathrm{MnO}, \mathrm{MgO}$ ). Axes are first and second (left side) and first and third (right side) principal components; first principal component as horizontal axis in both cases. Percentages indicate proportions of total variability. (a) Crustal-and mantle-derived garnets. (b) Garnets derived from igneous rocks. (c) Garnets derived from metapelites.

\section{Discussion}

Examination of the various discrimination diagrams for garnet (Fig. 4, Fig. 5, Fig. 6, Fig. 7, Fig. 8 and Fig. 9) reveals that these diagrams are partly imprecise and need to be improved, although they are commonly used for source rock discrimination. The diagram of Grütter et al. (2004) can only be used for a limited range of garnet compositions, to classify mantle-derived garnets. It is not applicable for sandstone provenance, except maybe if any detrital garnet with high chromium content is measured.

None of the evaluated ternary diagrams is usable for magmatic garnets, except for garnets derived from felsic plutonic rocks (Fig. 11). Purely almandine garnet in volcanic rocks is rare, because it can only develop under restricted conditions. Its development depends on water content in the melt and of the geodynamic setting, for example, tensional stress field, which offers rapid ascent of a garnet-bearing melt (Harangi et al., 2001). That is the reason why there exist only a few volcanic rocks carrying garnets. In addition, it is difficult to classify garnets derived from mafic magmatic rocks, because their chemical compositions are similar to garnets derived from metamorphic rocks. For example, garnets derived from gabbros have high pyrope content, similar to garnets from granulites and eclogites. Garnets derived from andesites, dacites or rhyolites show similar composition to garnets derived from metapelites (Fig. 11). Because of that and the relatively rare occurrences of garnetbearing volcanic rocks, volcanic and mafic plutonic garnets are not considered in the discrimination diagrams. The diagrams are thus only suited for granitic garnetbearing rocks and pegmatites. Therefore, when analysing detrital garnets one needs to consider if there may have been garnet-bearing volcanic rocks in the potential source area, which could have supplied volcanic garnets, which could then be misinterpreted. 


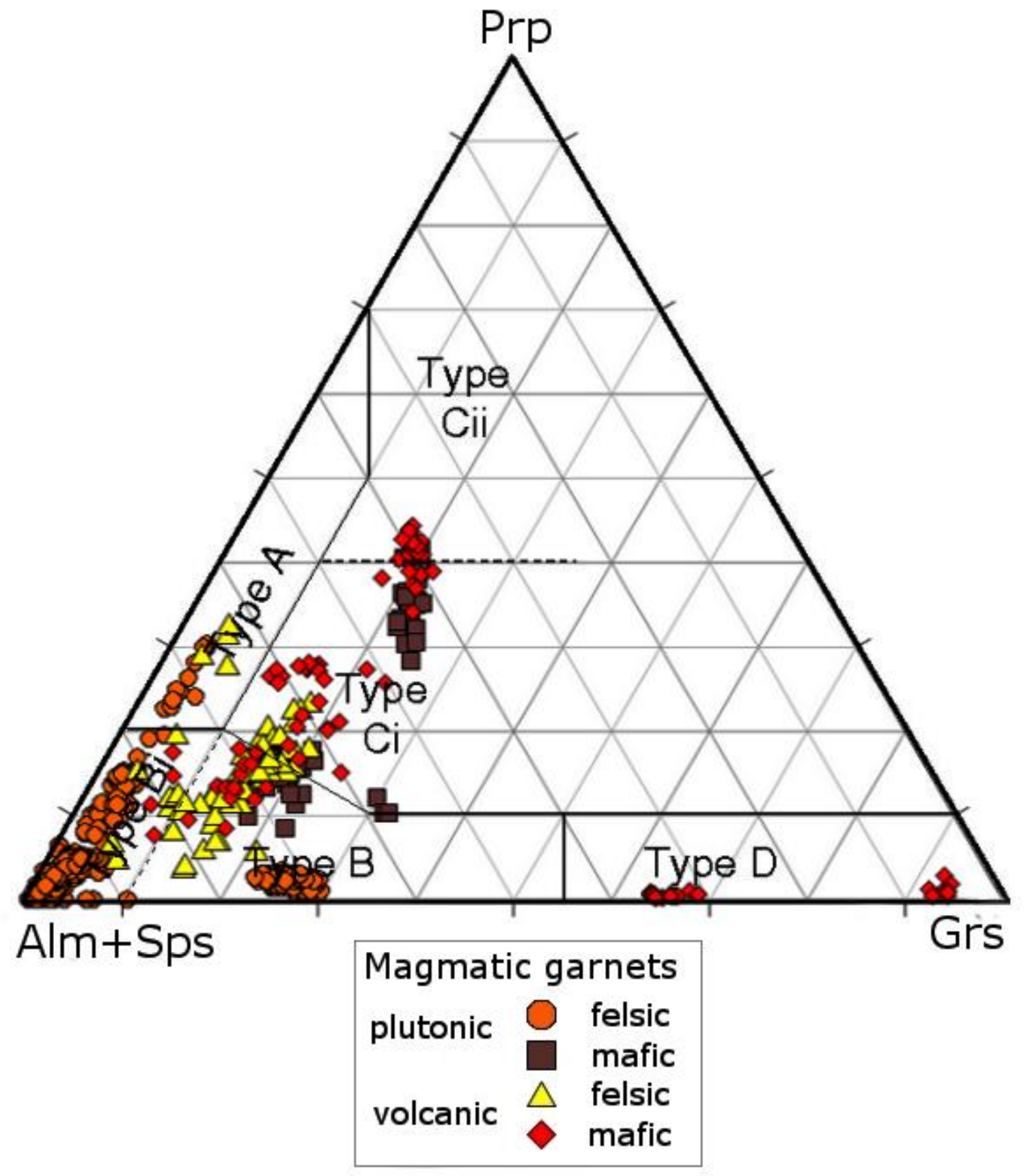

Fig. 11. Ternary discrimination diagrams after Mange and Morton (2007). Illustrated is a plot of garnets derived from magmatic rocks, divided in plutonic and volcanic and felsic and mafic rocks. A mainly from high-grade granulite-facies metasediments or charnockites and intermediate felsic igneous rocks, $\mathrm{B}$ - amphibolite-facies metasedimentary rocks, $\mathrm{Bi}$ - intermediate to felsic igneous rocks, $\mathrm{Ci}$ - mainly from high-grade mafic rocks, Cii - ultramafics with high $\mathrm{Mg}$ (pyroxenites and peridotites), D - metasomatic rocks, very low-grade metamafic rocks and ultrahigh temperature metamorphosed calc-silicate granulites.

In view of detrital garnet provenance, it is also important to mention that garnets that have been affected by retrograde metamorphism cannot be assigned to a specific rock type. For example, garnets from retrograde eclogites plot in the field of garnets 
from amphibolites and metapelites (Fig. 12). For discrimination, it does not matter whether the diagram of Wright (1938), Mange and Morton (2007), or Aubrecht et al. (2009) is used (Fig. 4, Fig. 5, Fig. 6 and Fig. 7), because their potential for successful discrimination is largely similar (Table 3) (Fig. 13). Discrimination only works for mantle-derived garnets, for a very small group of garnets derived from granites and pegmatites, and for some garnets from granulite-facies metasediments. Only $3 \%$ of garnets derived from peridotites cannot be discriminated from crustal-derived garnets. Garnets with high pyrope content $(>40 \%)$ are likely originated from mantlederived rocks. If garnets plot in field $\mathrm{Ci}$ (Mange and Morton, 2007) or in fields 2-5 (Aubrecht et al., 2009) it is highly probable that these garnets originate from metaigneous rocks such as eclogites, granulites, and amphibolites, and not from metasedimentary rocks. However, a further discrimination of these garnets is not possible. Discrimination of different grades of metasedimentary garnets is difficult. Only half of the garnets derived from eclogite-facies metasedimentary rocks, and 39 out of 178 granulite-facies metasedimentary derived garnets can be discriminated. However, it is very probable that garnets falling in field A (Mange and Morton, 2007) originate from high-grade granulite-facies metasediments. Garnets located in field B and also in field Bi (Mange and Morton, 2007) or in field 6-7 (Aubrecht et al., 2009) are likely derived from metasedimentary rocks up to amphibolite-facies rather than from metaigneous rocks; however, there exist some overlap with garnets derived from metaigneous amphibolites. Because garnets derived from metasedimentary rocks also plot in field $\mathrm{Bi}$ (Mange and Morton, 2007) and field 6 (Aubrecht et al., 2009) they cannot be clearly discriminated from felsic to intermediate igneous garnets. However, garnets with a high almandine + spessartine content of $>97 \%$ are likely derived from granites or pegmatites. 


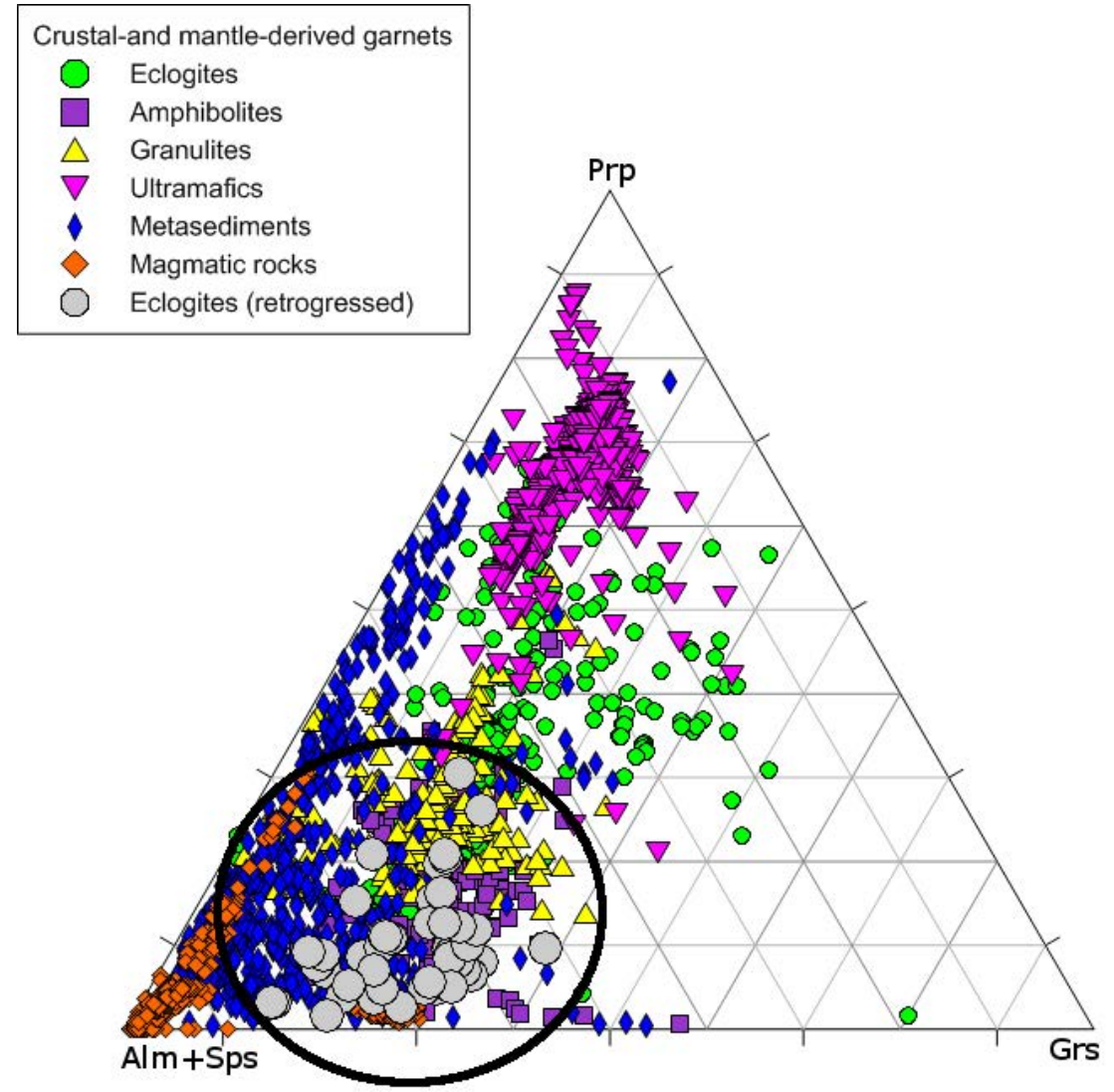

Fig. 12. Ternary discrimination diagram after Mange and Morton (2007). All garnets of the database are plotted here. The plot further contains garnets derived from retrogressed eclogites (grey circles). A - mainly from high-grade granulite-facies metasediments or charnockites and intermediate felsic igneous rocks, $\mathrm{B}$ - amphibolite-facies metasedimentary rocks, $\mathrm{Bi}$ - intermediate to felsic igneous rocks, $\mathrm{Ci}$ - mainly from high-grade mafic rocks, Cii - ultramafics with high $\mathrm{Mg}$ (pyroxenites and peridotites), D - metasomatic rocks, very low-grade metamafic rocks and ultrahigh temperature metamorphosed calc-silicate granulites. 

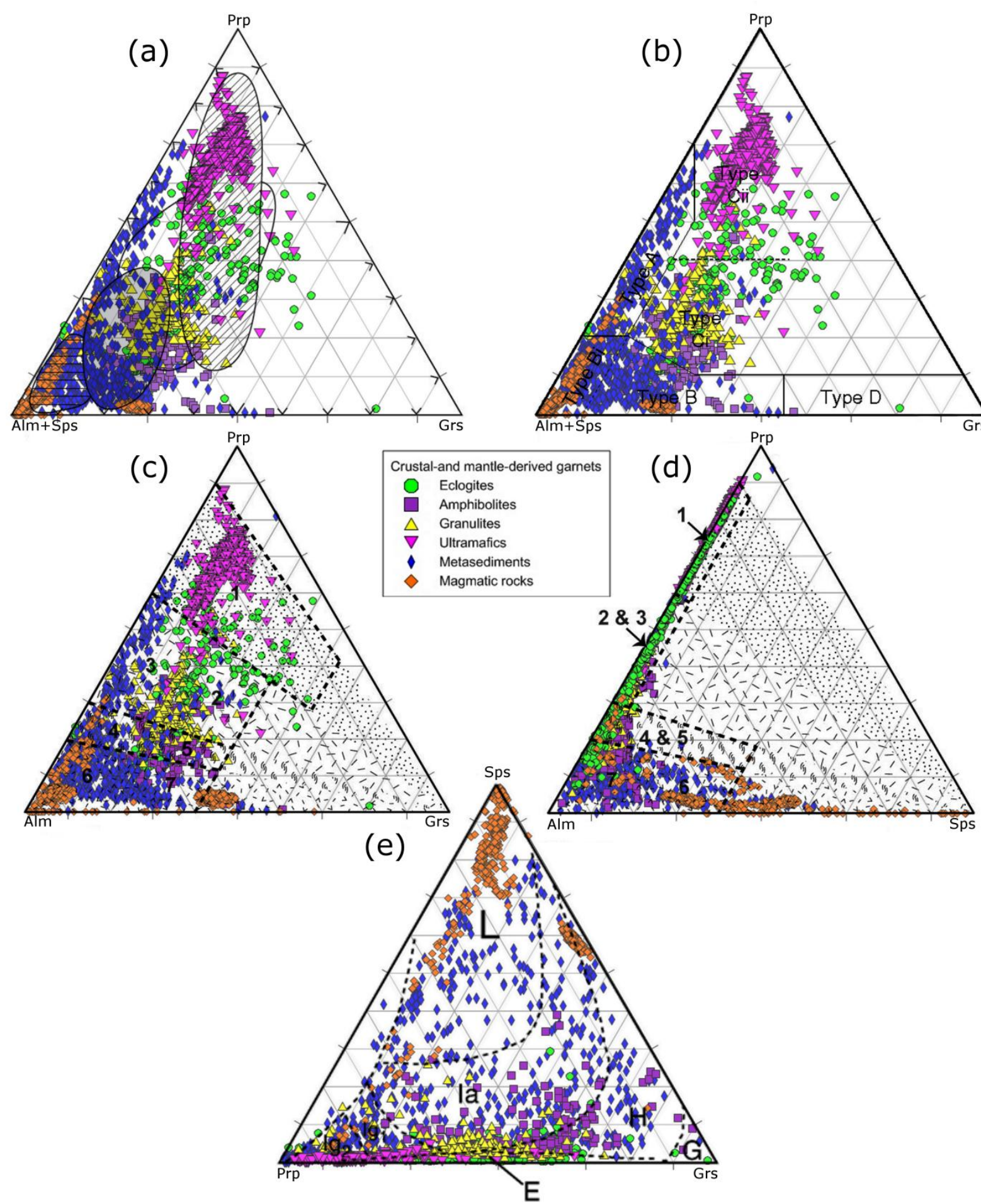

(b)

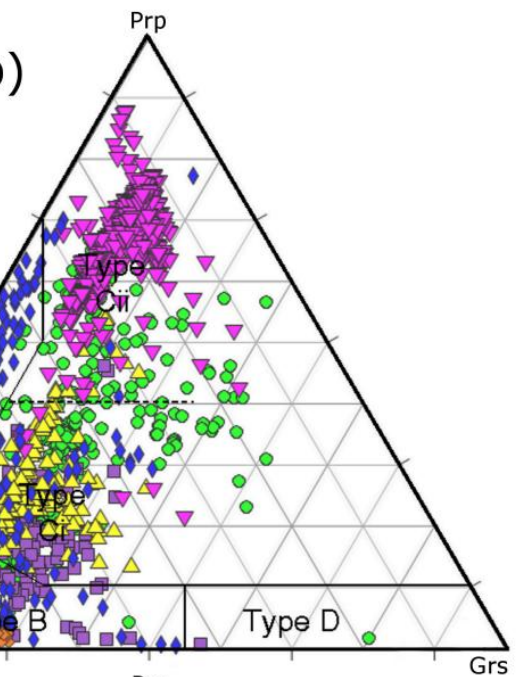
s 
The diagram of Teraoka et al. (1998) is of little help for discriminating garnets. It is not useful to remove the Fe component, which is essential to discriminate metasedimentary garnets from metaigneous garnets. In addition, mantle-derived garnets cannot be discriminated from granulite-facies derived garnets. If garnets plot in field $L$, it is highly probable that these garnets derive from metasedimentary garnets up to amphibolite-facies conditions. However, there exists some overlap with garnets derived from granites and pegmatites (Fig. 13).

The diagram of Suggate and Hall (2013) is a reasonable approach for a better discrimination of garnets; however, it does not resolve the problem of much overlap between garnets derived from amphibolites, granulites, blueschists, and eclogitefacies rocks (Fig. 3).

The biplots show that they do not solve the problem of some overlap of different types of garnets (Fig. 10). Nevertheless, there is a significant better discrimination of garnets derived from granites from garnets derived from metapelites than in the ternary diagrams, where only an insignificant part of garnets derived from granites can be discriminated. To get a more conclusive result, combining two or more diagrams can be helpful, but the value of this approach is limited because many of the individual diagrams use the same poles.

In the case of marked garnet zoning, measured data points of core and rim can provide different results. For example, depending on increasing or decreasing pressure and temperature conditions, garnet cores can indicate eclogitic origin, whereas garnet rims indicate lower metamorphic origin, or even vice versa. If garnets show marked zoning, it is important to measure core and rim of the garnets and if possible also the mantle. When dealing with detrital garnet, zoning cannot always be observed and can lead to some mismatch. It is not considered useful to calculate the mean value of the measured data points. For example, using this approach, the eclogitic garnets in Fig. 12 would be interpreted as lower grade metamorphic garnets. Instead, we recommend that all measured garnet data (core, mantle, rim) are plotted together in the individual diagrams in order to fully evaluate the origin of the garnet. All data are plotted together, because in the case of detrital garnet provenance the information of zoning is often insufficient. It is important to bear in mind that a mismatch can be a result of biased information and is not only based on the inaccuracy of the specific diagrams. 
Table 3. Qualitative evaluation of the potential of various diagrams for garnet discrimination. Note that magmatic garnets include volcanic and mafic plutonic rocks. Potential of discrimination:

very good: $\geq 90 \%$ success, good: $\geq 40 \%$ success, medium: $\geq 20 \%$ success, bad: $\leq 10 \%$ success.

\begin{tabular}{|c|c|c|c|c|c|}
\hline Lithology & $\begin{array}{l}\text { Wright } \\
(1938) \\
(\mathrm{N}=1324)\end{array}$ & $\begin{array}{l}\text { Mange and } \\
\text { Morton }(2007) \\
(\mathrm{N}=2956)\end{array}$ & $\begin{array}{l}\text { Aubrecht et al. } \\
(2009) \text {, diagram } 1 \\
(\mathrm{~N}=2956)\end{array}$ & $\begin{array}{l}\text { Aubrecht et al. (2009), } \\
\text { diagram } 2 \\
(\mathrm{~N}=2956)\end{array}$ & $\begin{array}{l}\text { Teraoka et al. } \\
(1998) \\
(\mathrm{N}=1532)\end{array}$ \\
\hline ultramafics & very good & very good & very good & very good & bad \\
\hline metaigneous eclogites & good & good & good & good & bad \\
\hline metaigneous amphibolites & bad & bad & bad & bad & bad \\
\hline metaigneous granulites & bad & bad & bad & bad & bad \\
\hline $\begin{array}{l}\text { felsic plutonic rocks } \\
\text { magmatic rocks (excluded are }\end{array}$ & bad & bad & bad & bad & bad \\
\hline felsic plutonic rocks) & bad & bad & bad & bad & bad \\
\hline greenschist-facies metapelites & bad & bad & bad & bad & bad \\
\hline amphibolite-facies metapelites & bad & bad & bad & bad & bad \\
\hline granulite-facies metapelites & medium & medium & medium & medium & bad \\
\hline \multirow[t]{2}{*}{ eclogite-facies metapelites } & bad & bad & bad & bad & bad \\
\hline & $\begin{array}{l}\text { Grütter et } \\
\text { al. }(2004) \\
(\mathrm{N}=1135) \\
\end{array}$ & & & & \\
\hline low-Cr megacrysts & very good & & & & \\
\hline harzburgites & good & & & & \\
\hline Iherzolites & good & & & & \\
\hline pyroxenites & bad & & & & \\
\hline eclogites & very good & & & & \\
\hline
\end{tabular}

\section{Conclusions and Outlook}

The present study clearly demonstrates that currently available discrimination diagrams for garnet are imprecise in clearly identifying the host rock of garnet. Many garnets of our large database plot outside their proposed compositional fields, with success rates of correct and unambiguous classification being $<50 \%$ for several garnet groups such as metaigneous and metasedimentary amphibolites, or metaigneous and metasedimentary granulites. In the binary and ternary plots, the discrimination fields between various garnet types are drawn as strict boundaries by solid lines, some of them showing distinct overlap. The most difficult problem is that garnets derived from different kind of garnet-bearing rocks share the same fields. For example, in the diagram of Mange and Morton (2007), garnets derived from metaigneous eclogites, amphibolites, and granulites share field $\mathrm{Ci}$. In the diagram of Aubrecht et al. (2009), garnets derived from amphibolite-facies metasediments and garnets derived from granites plot together in field $C_{2}$, even though they are of different origins.

Garnet discrimination diagrams show that a discrimination of different garnets based on major element composition is feasible, but limited. Biplot analysis reveals that the potential of discrimination based on major elements is not yet fully explored and a probabilistic approach appears to be better suited than strict boundaries between 
different garnet types. A further idea is to involve trace elements in these diagrams. The approach of combining major and trace elements is expected to provide a better discrimination of garnets. There exist some trace element data for garnets, but not to the same extent as major element data. It is therefore important to increase the amount of trace element data, so that a better discrimination of garnets can be achieved in the future.

Obviously, no statistic approach can solve the problem of real overlap of specific garnet suites. However, given that the examined discrimination diagrams rely on up to three variables only (some may be amalgamated), a robust multivariate statistical model involving confidence intervals and probability density distributions and taking into account the compositional nature of mineral chemical data, is considered most helpful to successfully improve discrimination of a wide range of garnet-bearing source rock lithologies.

\section{Acknowledgments}

The PhD scholarship of AK is financed by CASP. Fieldwork and analytical work was financed by the German Research Foundation (DFG grant EY 23/20-1). We thank Andreas Kronz for his help with electron microprobe analyses, and Jasper Knight and two anonymous reviewers for their constructive comments.

\section{References}

Aitchison, J., 1986. The statistical analysis of compositional data, monographs on statistics and applied probability. Chapman \& Hall Ltd, London, 416 pp.

Aitchison, J., 1990. Relative variation diagrams for describing patterns of compositional variability. Mathematical Geology 22, 487-511.

Aitchison, J., Egozcue, J.J., 2005.Compositional data analysis: Where are we and where should we be heading? Mathematical Geology 37, 829-850.

Allan, B.D., Clarke, D.B., 1981. Occurrence and origin of garnets in the South Mountain batholith, Nova Scotia. Canadian Mineralogist 19, 19-24.

Andò, S., 2007. Heavy minerals: provenance, hydraulic sorting, weathering. Unpublished PhD Thesis, University of Milano-Bicocca, $210 \mathrm{pp}$. 
Andò, S., Garzanti, E., Padoan, M., Limonta, M., 2012. Corrosion of heavy minerals during weathering and diagenesis: A catalog for optical analysis. Sedimentary Geology 208, 165-178.

Andò, S., Morton, A.C., Garzanti, E., 2013. Metamorphic grade of source rocks revealed by chemical fingerprints of detrital amphibole and garnet. In: Scott, R.A., Smyth, H.R., Morton, A.C., Richardson, N. (Eds.), Sediment Provenance Studies in Hydrocarbon Exploration and Production. Geological Society of London, Special Publications 386, http://dx.doi.org/10.1144/SP386.5.

Arredondo, E.H., Rossman, G.R., Lumpkin, G.R., 2001. Hydrogen in spessartinealmandine garnets as a tracer of granitic pegmatite evolution. American Mineralogist 86, 485-490.

Aubrecht, R., Méres, Š., Sýkora, M., Mikus, T., 2009. Provenance of the detrital garnets and spinels from the Albian sediments of the Czorsztyn Unit (Pieniny Klippen Belt, Western Carpathians, Slovakia). Geologica Carpathica 60, 463483.

Baldwin, J.R., von Knorring, O., 1983. Compositional range of Mn-garnet in zoned granitic pegmatites. Canadian Mineralogist 21, 683-688.

Biernacka, J., Józefiak, M., 2009. The Eastern Sudetic Island in the Early-to-Middle Turonian: evidence from heavy minerals in the Jerzmanice sandstones, SW Poland. Acta Geologica Polonica 59, 545-565.

Chappell, B.W., White, A.J.R., 1991. Restite enclaves and the restite model. In: Didier, J., Barbarin, B. (Eds.), Enclaves and Granite Petrology. Developments in Petrology 13, pp. 479-492.

Cong, B., Zhai, M., Carswell, T.A., Wilson, R.N., Wang, Q., Zhao, Z., Windley, B.F., 1995. Petrogenesis of ultrahigh-pressure rocks and their country rocks at Shuanghe in Dabieshan, central China. European Journal of Mineralogy 7, 119138.

Cookenboo, H.O., Grütter, H.S., 2010. Mantle-derived indicator mineral compositions as applied to diamond exploration. Geochemistry: Exploration, Environment, Analysis 10, 81-95.

Cuthbert, S.J., Carswell, D.A., Krogh-Ravna, E.J., Wain, A., 2000. Eclogites and eclogites in the Western Gneiss Region, Norwegian Caledonides. Lithos 52, 165-195. 
Day, R.A., Green, T.H., Smith, I.E.M., 1992. The origin and significance of garnet phenocrysts and garnet-bearing xenoliths in Miocene calc-alkaline volcanics from Northland, New Zealand. Journal of Petrology 33, 125-161.

Deer, W.A., Howie, R.A., Zussman, J., 1992. An introduction to rock-forming minerals. Longman Group Ltd, Harlow, UK, 712 pp.

Desmons, J., Smulikowski, W., 2004. A systematic nomenclature for metamorphic rocks: High P/T metamorphic rocks. Recommendation by the IUGS Subcommission on the Systematics of Metamorphic Rocks, http://www.bgs.ac.uk/SCMR

Escuder-Viruete, J., Indares, A., Arenas, R., 2000. P-T paths derived from garnet growth zoning in an extensional setting: an example from the Tormes Gneiss Dome (Iberian Massif, Spain). Journal of Petrology 41, 1489-1515.

Farges, F., 1998. Mineralogy of the Louvres Merovingian garnet cloisonné jewellery. Origins of the gems of the first kings of France. American Mineralogist 83, 323330.

Fipke, C.E., Gurney, J.J., Moore, R.O., 1995. Diamond exploration techniques emphasising indicator mineral geochemistry and Canadian examples. Geological Survey of Canada Bulletin 423, 86 pp.

Gabriel, K.R., 1971. The biplot-graphic display of matrices with application to principal component analysis. Biometrica 58, 453-467.

Garzanti, E., Andò, S., Vezzoli, G., 2009. Grain-size dependence of sediment composition and environmental bias in provenance studies. Earth and Planetary Science Letters, 277, 422-432.

Garzanti, E., Resentini, A., Vezzoli, G., 2010. Detrital fingerprints of fossil continentalsubduction zones (Axial Belt Provenance, European Alps). Journal of Geology 118, 341-362.

Garzanti, E., Limonta, M., Resentini, A., Bandopadhyay, P.C., Najman, Y., Andò, S., Vezzoli, G., 2013. Sediment recycling at convergent plate margins (Indo-Burman Ranges and Andaman-Nicobar Ridge. Earth-Science Reviews 123, 113-132.

Gilbert, J.S., Rogers, N.W., 1989. The significance of garnet in the PermoCarboniferous volcanic rocks of the Pyrenees. Journal of the Geological Society of London 146, 477-490.

Green, T.H., 1977. Garnet in silicic liquids and its possible use as a $P-T$ indicator. Contributions to Mineralogy and Petrology 65, 59-67. 
Green, T.H., 1992. Experimental phase equilibrium studies of garnet-bearing l-type volcanic and high-level intrusive from Northland, New Zealand. Transactions of the Royal Society of Edinburgh: Earth Sciences 83, 429-438.

Grew, E.S., Locock, A.J., Mills, S.J., Galuskina, I.O., Galuskina, E.V., Hålenius, U., 2013. Nomenclature of the garnet supergroup. American Mineralogist 98, 785811.

Grütter, H.S., Gurney, J.J., Menzies, A.H., Winter, F., 2004. An updated classification scheme for mantle-derived garnets, for use by diamond explorers. Lithos 77 , 841-857.

Hall, A., 1965. The origin of accessory garnet in the Donegal granite. Mineralogical Magazine 35, 628-633.

Harangi, S., Downes, H., Kosa, L., Szabo, C., Thirlwall, M.F., Mason, P.R.D., Mattey, D., 2001. Almandine garnet in calc-alkaline volcanic rocks of the Northern Pannonian Basin (Eastern-Central Europe): geochemistry, petrogenesis and geodynamic implications. Journal of Petrology 42, 1813-1843.

Harrison, T.N., 1988. Magmatic garnets in the Cairngorm granite, Scotland. Mineralogical Magazine 52, 659-667.

Haughton, P.D.W., Farrow, C.M., 1989. Compositional variation in Lower Old Red Sandstone detrital garnets from the Midland valley of Scotland and the AngloWelsh Basin. Geological Magazine 126, 373-396.

Heimann, A., Spry, P.G., Teale, G.S., Conor, C.H.H., Leyh, W.R., 2011. Geochemistry of garnet-rich rocks in the southern Curnamona Province, Australia and their genetic relationship to Broken Hill-Type Pb-Zn-Ag mineralization. Economic Geology 104, 687-712.

Hickmott, D.D., Shimizu, N., Spear, F.S., Selverstone, J., 1987. Trace element zoning in a metamorphic garnet. Geology 15, 573-576.

Hubert, J.F., 1962. A zircon-tourmaline-rutile maturity index and the interdependence of the composition of heavy mineral assemblages with the gross composition and texture of sandstones. Journal of Sedimentary Geology 32, 440-450.

Jung, S., Hellebrandt, E., 2006. Trace element fractionation during high-grade metamorphism and crustal melting-constraints from ion microprobe data of metapelitic, migmatitic and igneous garnets and implications for Sm-Nd garnet chronology. Lithos 87, 193-213. 
Kawabata, H., Takafuji, N., 2005. Origin of garnet crystals in calc-alkaline volcanic rocks from the Setouchi volcanic belt, Japan. Mineralogical Magazine 69, 951971.

Keulen, N., Frei, D., Bernstein, S., Hutchison, M.T., 2008. Fully automated analysis of grain chemistry, size and morphology by CCSEM: examples from cement production and diamond exploration. Geological Survey of Denmark and Greenland Bulletin 15, 93-96.

Krippner, A., Bahlburg, H., 2013. Provenance of Pleistocene Rhine River Middle Terrace sands between the Swiss-German border and Cologne based on $\mathrm{U}-\mathrm{Pb}$ detrital zircon ages. International Journal of Earth Sciences 102, 917-932.

Labus, M., 2005. Compositional Data Analysis as a tool for interpretation of rock porosity. Geological Quarterly 49, 347-354.

Liu, J., Liou, J.G., 1995. Kyanite-anthophyllite schist and the southwest extension of the Dabie Mountains ultrahigh- to high-pressure belt. Island Arc 4, 334-346.

Mange, M.A., Morton, A.C., 2007. Geochemistry of heavy minerals. In: Mange, M.A., Wright, D.T. (Eds.), Heavy Minerals in Use. Developments in Sedimentology 58, Elsevier, Amsterdam, pp. 345-391.

Manning, D.A.C., 1983. Chemical variation in garnets from aplites and pegmatites, peninsular Thailand. Mineralogical Magazine 47, 353-358.

Mathis, F., Vrielynck, O., Laclavetine, K., Chene, G., Strivay, D., 2008. Study of the provenance of Belgian Merovingian garnets by PIXE at IPNAS cyclotron. Nuclear Instruments \& Methods in Physics Research Section B, Beam Interactions with Materials and Atoms 266, 2348-2352.

Meinhold, G., Reischmann, T., Kostopoulos, D., Frei, D., Larionov, A.N., 2010. Mineral chemical and geochronological constraints on the age and provenance of the eastern Circum-Rhodope Belt low-grade metasedimentary rocks, NE Greece. Sedimentary Geology 229, 207-223.

Méres, S., Aubrecht, R., Gradzinski, M., Sýkora, M., 2012. High (ultrahigh) pressure metamorphic terrane rocks as the source of the detrital garnets from the Middle Jurassic sands and sandstones of the Cracow Region (Cracow-Wielun Upland, Poland). Acta Geologica Polonica 62, 231-245.

Miller, C.F., Stoddard, E.F, 1981. The role of manganese in the paragenesis of magmatic garnet: an example from the Old Woman-Piute Range, California. Journal of Geology 89, 233-246. 
Morton, A.C., 1984. Stability of detrital heavy minerals in Tertiary sandstones of the North Sea Basin. Clay Minerals 19, 287-308.

Morton, A.C., 1985. A new approach to provenance studies: electron microprobe analysis of detrital garnets from Middle Jurassic sandstones of the northern North Sea. Sedimentology 32, 553-566.

Morton, A.C., 1987. Influence of provenance and diagenesis on detrital garnet suites in the Forties sandstone, Paleocene, central North Sea. Journal of Sedimentary Petrology 57, 1027-1032.

Morton, A.C., 2012. Value of heavy minerals in sediments and sedimentary rocks for provenance, transport history and stratigraphic correlation. In: Sylvester, P. (Ed.), Quantitative Mineralogy and Microanalysis of Sediments and Sedimentary Rocks. Mineralogical Association of Canada Short Course Series 42, pp. 133165.

Morton, A.C., Hallsworth, C.R., 1999. Processes controlling the composition of heavy mineral assemblages in sandstones. Sedimentary Geology 124, 3-29.

Morton, A., Hallsworth, C., Chalton, B., 2004. Garnet compositions in Scottish and Norwegian basement terrains: a framework for interpretation of North Sea sandstone provenance. Marine and Petroleum Geology 21, 393-410.

Morton, A.C., Whitham, A.G., Fanning, C.M., 2005. Provenance of Late Cretaceous to Paleocene submarine fan sandstones in the Norwegian Sea: Integration of heavy mineral, mineral chemical and zircon age data. Sedimentary Geology 182, 3-28.

Morton, A.C., Meinhold, G., Howard, J.P., Phillips, R.J., Strogen, D., Abutarruma, Y., Elgadry, M., Thusu, B., Whitham, A.G., 2011. A heavy mineral study of sandstones from the eastern margin of the Murzuq Basin, Libya: Constraints on provenance and stratigraphic correlation. Journal of African Earth Sciences, 61, 308-330.

Nandi, K., 1967. Garnets as indices of progressive regional metamorphism. Mineralogical Magazine 36, 89-93.

Nowicki, T., Dyck, D., Carlson, J., Helmstaedt, H., 2003. The geology of kimberlite pipes of the Ekati property, Northwest Territories, Canada. Lithos 76, 1-27.

Okay, A.I., 1993. Petrology of a diamond and coesite-bearing metamorphic terrain: Dabie Shan, China. European Journal of Mineralogy 5, 659-675. 
Otamendi, J.E., de la Rosa, J.D., Patino Douce, A.E., Castro, A., 2002. Rayleigh fractionation of heavy rare earths and yttrium during metamorphic garnet growth. Geology 30, 159-162.

Patranabis-Deb, S., Schieber, J., Basu, A., 2008. Almandine garnet phenocrysts in a $\sim 1 \mathrm{Ga}$ rhyolitic tuff from central India. Geological Magazine 146, 133-143.

Pawlowsky-Glahn, V., Egozcue, J., 2006. Compositional data and their analysis: an introduction. In: Buccianti, A., Mateu-Figueras, G., Pawlowsky-Glahn, V. (Eds.), Compositional data analysis in the Geosciences: From Theory to Practice. Geological Society of London, Special Publication 264, pp. 1-10.

Petermann, E.M., Hacker, B.R., Baxter, E.F., 2009. Phase transformations of continental crust during subduction and exhumation: Western Gneiss Region, Norway. European Journal of Mineralogy 21, 1097-1118.

Pettijohn, F.J., 1941. Persistence of heavy minerals and geological age. Journal of Geology 49, 610-625.

Price, J.R., Bryan-Ricketts, D.S., Anderson, D., Velbel, M.A., 2013. Weathering of almandine garnet: Influence of secondary minerals on the rate-determining step, and implications for regolith-scale Al mobilization. Clays and Clay Minerals 61, 34-56.

Quast, D., Schüssler, U., 2000. Mineralogische Untersuchungen zur Herkunft der Granate merowingerzeitlicher Cloisonnéarbeiten. Germania 78, 75-96.

René, M., Stelling, J., 2007. Garnet-bearing granite from the Třebíč pluton, Bohemian Massif (Czech Republic). Mineralogy and Petrology 91, 55-69.

Sabeen, H.M., Ramanujam, N., Morton, A.C., 2002. The provenance of garnet: constraints provided by studies of coastal sediments from southern India. Sedimentary Geology 152, 279-287.

Schmid, R., Fettes, D., Harte, B., Davis, E., Desmons, J., Meyer-Marsilius, H.J., Siivola, J. 2004. A systematic nomenclature for metamorphic rocks. 1. How to name a metamorphic rock. Recommendation by the IUGS Subcommission on the systematics of metamorphic rocks, http://www.bgs.ac.uk/SCMR

Schmid, S., Scharf, A., Handy, M.R., Rosenberg, C.L., 2013. The Tauern Window (Eastern Alps. Austria): a new tectonic map, with cross-sections and a tectonometamorphic synthesis. Swiss Journal of Geosciences 106, 1-32. 
Schuiling, R.D., de Meijer, R.J., Riezebos, H.J., Scholten, M.J., 1985. Grain-size distribution of different minerals in a sediment as a function of their specific density. Geologie en Mijnbouw 64, 199-203.

Schulze, D.J., 1997. The significance of eclogite and Cr-poor megacryst garnets in diamond exploration. Exploration and Mining Geology 6, 349-366.

Schulze, D.J., Valley, J.R., Bell, D.R., Spicuzza, M.J., 2001. Oxygen isotope variations in Cr-poor megacrysts from kimberlite. Geochimica et Cosmochimica Acta 65, 4375-4384.

Schulze, D.J., 2003. A classification scheme for mantle-derived garnets in kimberlite: a tool for investigating the mantle and exploring for diamonds. Lithos 71, 195213.

Seifert, A.V., Vrána, S., 2005. Bohemian garnet. Bulletin of Geosciences 80, 113124.

Spear, F.S., 1993. Metamorphic phase equilibria and pressure-temperature-time paths. Mineralogical Society of America, Washington, D.C., 799 pp.

Stone, J., 1988. The significance of almandine garnets in the Lundy and Dartmoor granites. Mineralogical Magazine 52, 651-658.

Su, B., Zhang, H., Tang, Y., Chisonga, B., Qin, K., Ying, J., Asamoah Sakyi, P., 2011. Geochemical syntheses among the cratonic, off-cratonic and orogenic garnet peridotites and their tectonic implications. International Journal of Earth Sciences 100, 695-715.

Suggate, S.M., Hall, R., 2013. Using detrital garnet compositions to determine provenance: a new compositional database and procedure. In: Scott, R.A., Smyth, H.R., Morton, A.C., Richardson, N. (Eds.), Sediment provenance studies in hydrocarbon exploration and production. Geological Society of London, Special Publication 386, http://dx.doi.org/10.1144/SP386.8

Tabata, H., Yamauchi,K., Maruyama, S., Liou, J.G., 1998. Tracing the extent of a UHP metamorphic terrane: A mineral-inclusion study of zircons in gneisses from the Dabie Shan. In: Hacker, B.R., Liou, J.G. (Eds.), When continents collide: Geodynamics and geochemistry of ultrahigh-pressure rocks. Kluwer Academic Publishers, Dordrecht, pp. 261-274.

Takeuchi, M., 1994. Changes in garnet chemistry show a progressive denudation of the source areas for Permian-Jurassic sandstones, Southern Kitakami Terrane, Japan. Sedimentary Geology 93, 85-105. 
Teraoka, Y., Suzuki, M., Hayashi, T., Kawakami, K., 1997. Detrital garnets from Paleozoic and Mesozoic sandstones in the Onogawa area, East Kyushu, Southwest Japan. Bulletin of the Faculty of School Education, Hiroshima University, Part II, 19, 87-101 (in Japanese with English abstract).

Teraoka, Y., Suzuki, M., Kawakami, K., 1998. Provenance of Cretaceous and Paleogene sediments in the Median Zone of Southwest Japan. Bulletin of the Geological Society of Japan 49, 395-411 (in Japanese with English abstract).

Tröger, E., 1952. Die Granatgruppe: Beziehungen zwischen Mineralchemismus und Gesteinsart. Neues Jahrbuch für Mineralogie Abhandlungen 93, 1-44.

Turner, G., Morton, A.C., 2007. The effects of burial diagenesis on detrital heavy mineral grain surface textures. In: Mange, M., Wright, D.K. (Eds.), Heavy Minerals In Use. Developments in Sedimentology 58, Elsevier, Amsterdam, pp. 393-412.

van den Boogaart, K.G., Tolosana-Delgado, R., 2008."compositions": A unified package to analyze compositional data. Computers \& Geosciences 34, 320-338. Velbel, M.A., 1984. Natural weathering mechanisms of almandine garnet. Geology $12,631-634$.

Velbel, M.A., 2007. Surface textures and dissolution processes of heavy minerals in the sedimentary cycle: examples from pyroxenes and amphiboles. In: Mange, M., Wright, D.K. (Eds.), Heavy Minerals In Use. Developments in Sedimentology 58, Elsevier, Amsterdam, pp. 112-150.

Vennum, W.R., Meyer C.H.E., 1979. Plutonic garnets from the Werner batholith, Lassiter coast, Antarctic Peninsula. American Mineralogist 64, 268-273.

von Eynatten, H., Gaupp, R., 1999. Provenance of Cretaceous synorogenic sandstones in the Eastern Alps: constraints from framework petrography, heavy mineral analysis and mineral chemistry. Sedimentary Geology 124, 81-111.

von Eynatten, H., Barceló-Vidal, C., Pawlowsky-Glahn, V., 2003. Composition and discrimination of sandstones: A statistical evaluation of different analytical methods. Journal of Sedimentary Research 73, 47-57.

von Eynatten, H., Dunkl, I., 2012. Assessing the sediment factory: the role of single grain analysis. Earth-Science Reviews 115, 97-120.

Walderhaug, O., Porten, K.W., 2007. Stability of detrital heavy minerals on the Norwegian continental shelf as a function of depth and temperature. Journal of Sedimentary Research 77, 992-1002. 
Wang, X., Liou, J.G., 1991. Regional ultrahigh-pressure coesitebearing eclogitic terrane in central China: evidence from country rocks, gneiss, marble, and metapelite. Geology 19, 933-936.

Wang, X., Liou, J.G., Maruyama, S., 1992. Coesite-bearing eclogite from the Dabie Mountains, central China: Petrogenesis, P-T path and implications for tectonics. Journal of Geology 100, 231-250.

Weisbrod, A., 1974. Étude experimentale de l'équilibre grenat-cordiérite dans le système $\mathrm{Mn}-\mathrm{Fe}-\mathrm{Al}-\mathrm{Si}-\mathrm{O}-\mathrm{H}$, à $750^{\circ} \mathrm{C}$. Implications thermodynamiques et pétrologiques. Bulletin de la Société Française Minéralogie et de Cristallographie 97, 261-270.

White, A.J.R., Chappell, B.W., 1977. Ultrametamorphism and granitoid genesis. Tectonophysics 43, 7-22.

Whitham, A.G., Morton, A.C., Fanning, C.M., 2004. Insights into CretaceousPalaeogene sediment transport paths and basin evolution in the North Atlantic from a heavy mineral study of sandstones from southern East Greenland. Petroleum Geoscience 10, 61-72.

Whitworth, M.P., 1992. Petrogenetic implications of garnets associated with lithium pegmatites from SE Ireland. Mineralogical Magazine 56, 75-83.

Win, K.S., Takeuchi, M., Iwakiri, S., Tokiwa, T., 2007. Provenance of detrital garnets from the Yukawa Formation, Yanase district, Shimanto belt, Kii Peninsula, Southwest Japan. Journal of the Geological Society of Japan 113, 133-145.

Wotzlaw, J.F., Decou, A., von Eynatten, H., Wörner, G., Frei, D., 2011. Jurassic to Palaeogene tectono-magmatic evolution of northern Chile and adjacent Bolivia from detrital zircon $\mathrm{U}-\mathrm{Pb}$ geochronology and heavy mineral provenance. Terra Nova 23, 399-406.

Wright, W.I., 1938. The composition and occurrence of garnets. American Mineralogist 23, 436-449.

Yuan, C., Sun, M., Xiao, W., Wilde, S., Li, X., Liu, X., Long, X., Xia, X., Ye, K., Li, J., 2009. Garnet-bearing tonalitic porphyry from East Kunlun, Northeast Tibetan Plateau: implications for adakite and magmas from the MASH Zone. International Journal of Earth Sciences 98, 1489-1510.

Zemann, J., 1962. Zur Kristallchemie der Granate. Beiträge zur Mineralogie und Petrographie 8, 180-188. 


\title{
Chapter III:
}

\section{Manuscript II: Grain-size dependence of garnet composition revealed by provenance signatures of modern stream sediments from the western Hohe Tauern (Austria)}

\author{
Anne Krippner ${ }^{1, *}$, Guido Meinhold ${ }^{1}$, Andrew C. Morton ${ }^{2,3}$, Eva Russell ${ }^{1}$, Hilmar von \\ Eynatten $^{1}$
}

${ }^{1}$ Department of Sedimentology and Environmental Geology, University of Göttingen, Goldschmidtstraße 3, 37077 Göttingen, Germany

${ }^{2} \mathrm{CASP}$, University of Cambridge, West Building, 181A Huntingdon Road, Cambridge CB3 ODH, United Kingdom

${ }^{3} \mathrm{HM}$ Research Associates, 2 Clive Road, Balsall Common, West Midlands CV7 7DW, United Kingdom

Published in: Sedimentary Geology (2015) 321, 25-38

\section{Abstract}

Heavy minerals are valuable indicators about the geological framework in the source area. The heavy mineral garnet is one of the most widespread heavy minerals in orogenic sediments and its geochemistry provides important information about metamorphic conditions. The application of heavy minerals and garnet geochemistry for sedimentary provenance analysis is tested for modern stream sediments collected along three rivers draining the Eclogite Zone and adjacent geological source units of the western Hohe Tauern area in the central Eastern European Alps. For comparison with the stream sediments, rock outcrops exposed in this area were also sampled. The chosen area is very well investigated and provides an excellent place to constrain the relations between source rocks and sediment in first-order drainages. The influence of grain-size is studied in detail by considering grain-size fractions ranging from coarse silt to coarse sand (32 to $1000 \mu \mathrm{m}$ ). In all grain-size fractions the heavy mineral assemblages are characterised to a variable extent by 
epidote, zoisite, garnet, and green calcic amphibole. In the smaller grain-size fraction apatite is more frequent, whereas in the coarser grain-size fractions an increase of green calcic amphibole and garnet can be observed. Electron microprobe analysis of detrital garnet shows the dominance of almandine-rich garnet. Stream sediments within and downstream of the Eclogite Zone show an increase of pyrope-rich garnets. Interestingly, in all samples, grossular-rich garnets are more frequent in the smaller grain-sizes and pyrope-rich garnets are more frequent in the coarser grain-sizes. This is controlled by the original finer size distribution of grossular in the source rocks rather than being a hydraulic effect. The heavy mineral assemblages and garnet geochemical data reflect the geological setting of the study area, hence confirming the general strength of these methods in sedimentary provenance analysis. However, the data underline strong grain-size control on sediment composition including single-grain compositional variations.

Keywords: heavy minerals; garnet geochemistry; compositional biplot; Eclogite Zone; Eastern European Alps

\section{Introduction}

Modern stream sediments and adjacent source rocks from the western Hohe Tauern of the central Eastern European Alps were collected to constrain the source to sink relations of different garnet-bearing lithologies. The Alps are very well suited for such investigations, because the geology is well known, chemical weathering and climatic or diagenetic alteration are negligible, and sediment transport is rapid. Consequently, the first-cycle detritus is a good reflection of the mineralogy of the eroded parent rocks (Garzanti et al., 2010). Sediments were analysed for heavy minerals and both sediment and hardrock samples were analysed for garnet geochemistry. Heavy minerals are useful indicators of the provenance of sediments and sedimentary rocks, as they provide crucial information on the provenance from orogenic and other sources (e.g., Morton, 1991, Garzanti and Andò, 2007 and Garzanti et al., 2007). In an ideal case, the heavy mineral assemblages reflect their parent rock composition. For example, certain garnet composition can be related to specific source rocks, with higher MgO-rich garnets in high grade metamorphic rocks compared to low grade metamorphic rocks (e.g., Morton et al., 2004, Mange and Morton, 2007, Aubrecht et al., 2009, Andò et al., 2014, Krippner et al., 2014 and Suggate and Hall, 2014). 
Because the geochemistry of garnet depends on both the composition of its parent rock and on pressure and temperature conditions, we want to test to what extent the compositional variations of the garnets in the source rocks are reflected in the garnets of the sediments, and also if the heavy mineral assemblages and garnet composition reflect the geological situation in the catchment source area.

Hydrodynamic sorting of heavy minerals depends on grain-size, density, and shape (Morton and Hallsworth, 1999, Garzanti et al., 2008, Garzanti et al., 2009 and Garzanti et al., 2010). Effects of sorting due to different grain-size and density not only influence heavy mineral assemblages, but also can be observed in a single mineral group. For example, almandine-rich garnet species are typically concentrated in the finer fractions, in contrast to less dense garnet species (Schuiling et al., 1985, Andò, 2007 and Garzanti et al., 2008). Therefore, grain-size and density play an important role in sedimentary provenance analysis (e.g., Garzanti et al., 2009).

In our research the focus lies on the heavy mineral garnet, because it occurs in a very wide range of source rocks from ultramafic to felsic composition. It is a major constituent in crustal metamorphic rocks, a primary component in mantle rocks, and a common heavy mineral in siliciclastic sediments and sedimentary rocks. It also exists in magmatic rocks (e.g., Miller and Stoddard, 1981, Patranabis-Deb et al., 2008 and Baxter et al., 2013). Therefore, detrital garnet geochemistry has important provenance applications. However, several processes need to be considered when dealing with heavy minerals, because synsedimentary and diagenetic modifications of the original heavy mineral composition can lead to incorrect conclusions. Diagenetic modification of garnet assemblages has been recognised, with Ca-rich garnets being less stable than Ca-poor types (Morton, 1987 and Morton and Hallsworth, 2007). Hence, differences in heavy mineral assemblages or garnet compositions can reflect synsedimentary and/or diagenetic modifications and do not necessarily hint at different sources (e.g., Morton and Hallsworth, 1999 and Morton, 2012). Our results demonstrate that great care must be taken when analysing detrital mineral data if only considering a specific grain-size range.

\section{Geological setting}

The Hohe Tauern area in the central Eastern Alps (Austria) is dominated by the Tauern window (Fig. 1), which is a geological structure exposing an old continental 
basement belonging to the European foreland. The Subpenninic and Penninic domains in the Hohe Tauern consist of several units with different palaeographic affiliation (e.g., Dachs et al., 2005, Miller et al., 2007 and Pfiffner, 2014). The rocks building up these geological units underwent different metamorphic conditions during subduction and exhumation processes of various ages (e.g., Cadomian, Variscan, and Alpine). Our study area encompasses the south-trending valleys of Dorfertal, Timmeltal, and Frosnitztal, including three different rivers and enclosing the main structural units of the western Hohe Tauern (Fig. 1 and Fig. 2). This area is very suitable for studies on garnet, because rocks of the different geological source units suffered different metamorphic conditions, as outlined below, and particular garnetbearing rocks (e.g., garnet-micaschists, eclogites, amphibolites) are well exposed around these three valleys. The structurally deepest unit is the basal Venediger nappe, which encompasses Late Variscan granitoids (the Central Gneiss), metasedimentary rocks of the Lower Schieferhülle, and a few exposures of preAlpine eclogites (e.g., Zimmermann and Franz, 1989 and von Quadt et al., 1997). The latter represent mafic rocks with basaltic composition. They are fine- to mediumgrained rocks and show intensive foliation with amphibole and symplectitic garnetrich layers (Zimmermann and Franz, 1989 and von Quadt et al., 1997). The peak metamorphism in the Venediger nappe occurred at $\sim 11 \mathrm{kbar}$ and $\sim 540{ }^{\circ} \mathrm{C}$ (Selverstone, 1993). The Eclogite Zone is intercalated between the Venediger nappe and the overlaying Glockner nappe (including the Rote Wand-Modereck nappe for simplicity), which consists of metasediment and metamafic rocks of the Upper Schieferhülle with oceanic affinity that reached blueschist-facies metamorphism at $\sim 8 \mathrm{kbar}$ and $\sim 540{ }^{\circ} \mathrm{C}$ (Selverstone, 1993 and Hoschek, 2013). The eclogites in the Eclogite Zone are embedded in a matrix of Mesozoic quartzites, paragneisses, marbles, and garnet-micaschists (e.g., Neufeld et al., 2008 and Hoschek, 2013). The rocks of the Eclogite Zone were subducted and exhumed during CretaceousNeogene tectonometamorphic events. They reached peak metamorphism at $\sim 25$ kbar and $\sim 650{ }^{\circ} \mathrm{C}$ (Holland, 1979, Frank et al., 1987a, Stöckhert et al., 1997, Hoschek, 2007 and Neufeld et al., 2008) and were subsequently overprinted by a blueschist-facies metamorphic event (Miller, 1977, Holland, 1979, Frank et al., 1987a, Zimmermann et al., 1994, Kurz et al., 1998 and Miller et al., 2007). Finally, rocks of the Eclogite Zone underwent greenschist-amphibolite-facies metamorphism (Miller, 1977, Frank et al., 1987a, Dachs, 1990, Inger and Cliff, 1994, Zimmermann et 
al., 1994 and Miller et al., 2007). The eclogite lenses of the Eclogite Zone make up $\sim 30 \%$ of the Eclogite Zone (Neufeld et al., 2008). In contrast to the pre-Alpine eclogites of the Venediger nappe, those rocks suffered higher metamorphic peak conditions. As a result of these variable conditions of formation and metamorphism, a range of garnet types has been produced.
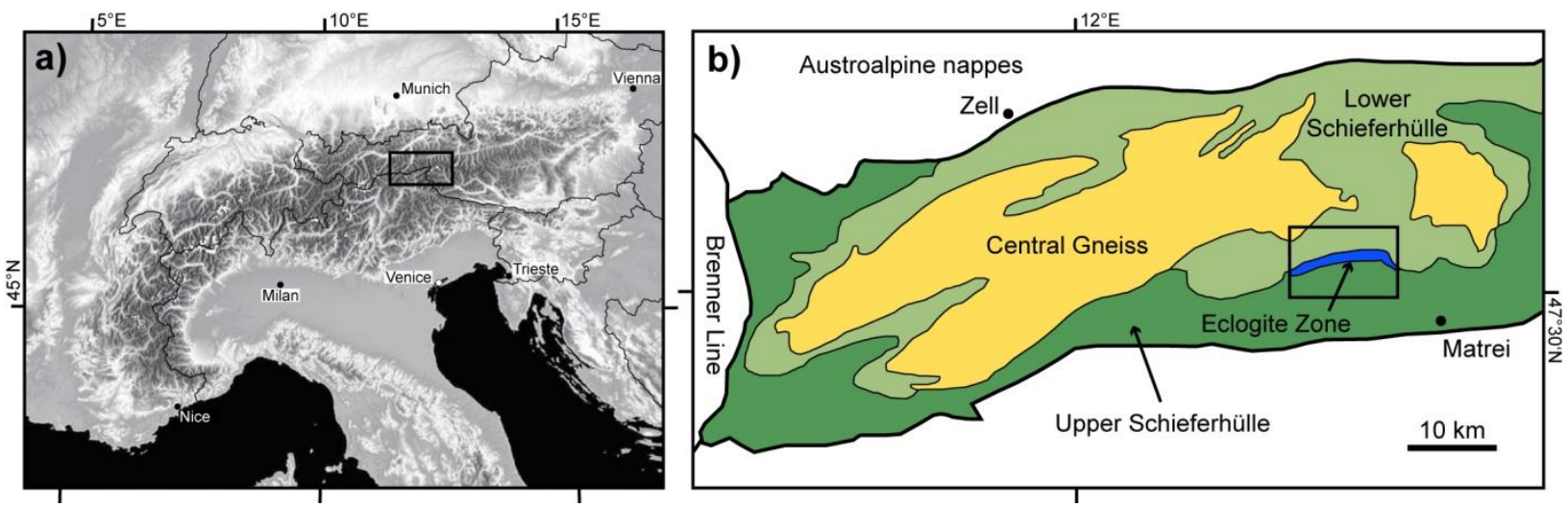

Fig. 1. a) Digital elevation model of the Alps and neighbouring areas (adapted from Pfiffner, 2014). The western Tauern window is shown in a box. b) Simplified geological map of the western Tauern window (modified from Hawkins et al., 2007). The study area is shown in a box.

\section{Samples and methods}

\subsection{Samples}

For our research 27 stream samples and 14 outcrop samples were collected from the three valleys. Additionally, in the Dorfertal, 5 pebbles were taken from the river bed. Several sections of recent fluvial deposits at riversides along the three different rivers were sampled from upstream to downstream (Fig. 2). Preferentially loose bedload sand was sampled to cover a wide grain-size range. If accessible, sediments and outcrop samples were collected from each geological source unit (Venediger nappe, Eclogite Zone, Glockner nappe) to analyse possible changes in the provenance signal from of each river. Stream sediment sample locations are shown in Fig. 2. Rock types and geographic coordinates of all samples are given in the accompanying Supplementary data (see Appendix A). 


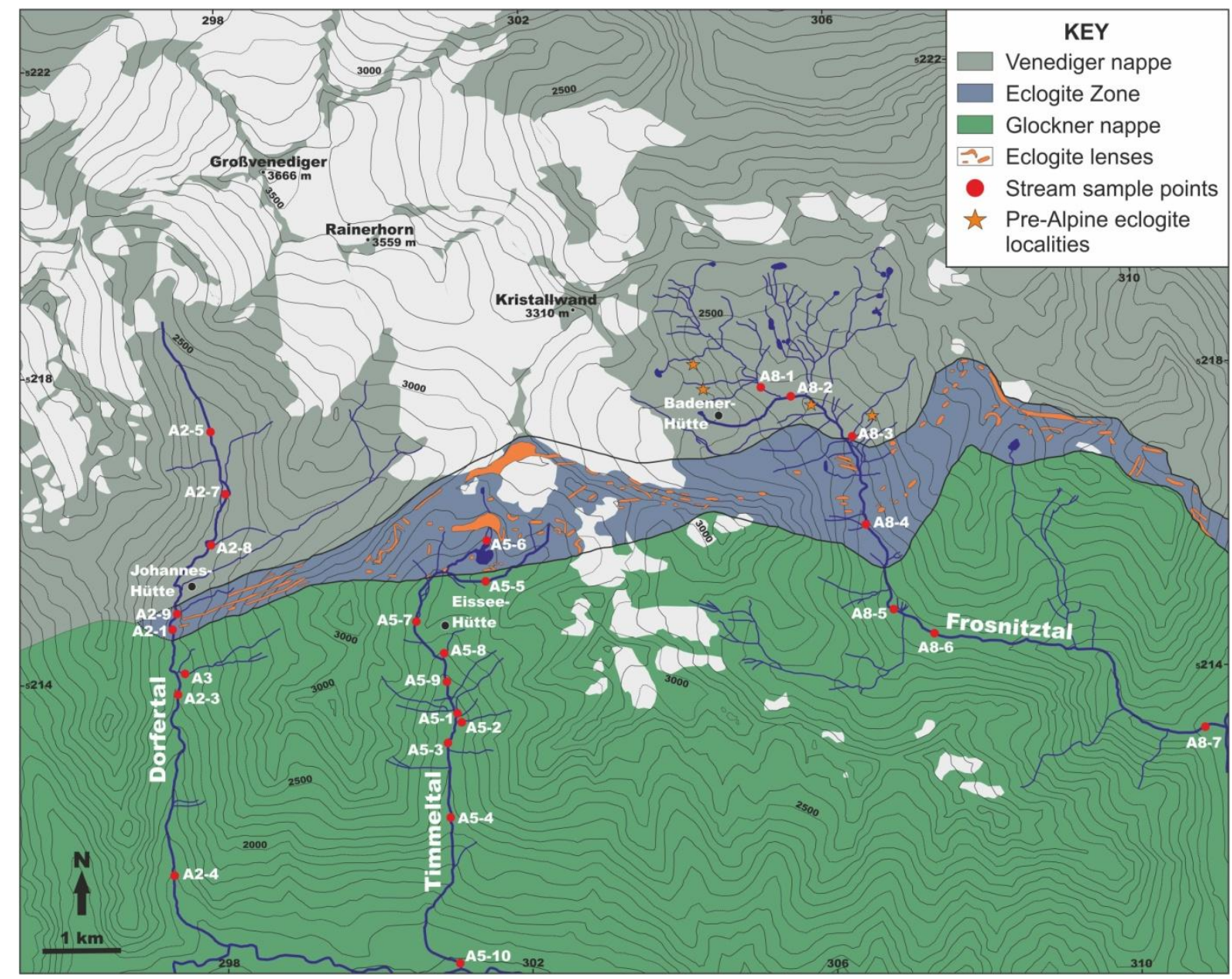

Fig. 2. Geological map of the southern Grossvenediger area based on the map sheet by Frank et al. (1987). For simplification, the Rote Wand-Modereck nappe is included in the Glockner nappe. Locations of pre-Alpine eclogites are according to Zimmermann and Franz (1989). Whitish parts illustrate ice sheet coverage.

\subsection{Methods}

All stream sediments were wet-sieved using a sieving machine to separate the different grain-size fractions $(32-63 \mu \mathrm{m}, 63-125 \mu \mathrm{m}, 125-250 \mu \mathrm{m}, 250-500 \mu \mathrm{m}$, 500-1000 $\mu \mathrm{m})$. After drying, the samples were treated with acetic acid to remove the carbonate component if present. The heavy mineral fractions were separated using Na-metatungstate with a density of $2.85 \mathrm{~g} / \mathrm{mL}$.

\subsubsection{Heavy mineral analysis}

The heavy mineral separates were mounted on microscope slides (Mange and Maurer, 1992) using Meltmount ${ }^{\mathrm{TM}}$ with a refraction of 1.66 and identified under the polarising microscope. The relative abundances of the heavy minerals were 
determined by grain counting. For that, the microscope slide was moved along linear traverses (i.e., ribbon counting). Two-hundred and fifty translucent 'non-micaceous' minerals per sample were counted (Mange and Maurer, 1992). Relative abundances of all heavy minerals including opaque minerals, micas, alterites (minerals with poorly defined mineralogical composition and which cannot be identified under the polarising microscope; van Andel, 1950), and "unknown" are included in the Supplementary data (see Appendix A) as well as only groups of transparent minerals and heavy mineral data from all grain-size fractions (see Appendix $A$ ).

\subsubsection{Garnet geochemistry}

Garnet selection from the river sediments was achieved by handpicking under a binocular microscope. We randomly selected garnet grains of all sizes and morphological types and placed them on synthetic mounts. From the hardrock samples polished thin sections were prepared. Hardrock and river samples were analysed with a JEOL JXA 8900 RL electron microprobe (EMP) equipped with five wavelength dispersive spectrometers at the University of Göttingen (Department of Geochemistry, Geoscience Center). Before analysis, all samples were coated with carbon to ensure conductivity. Conditions included an accelerating voltage of $15 \mathrm{kV}$ and a beam current of $20 \mathrm{nA}$. The counting times were $15 \mathrm{~s}$ for $\mathrm{Si}, \mathrm{Mg}, \mathrm{Ca}, \mathrm{Fe}$, and $\mathrm{Al}$, and $30 \mathrm{~s}$ for $\mathrm{Ti}, \mathrm{Cr}$, and $\mathrm{Mn}$. Matrix correction was performed using $\mathrm{ZAF}$ corrections. From the thin sections 20 garnet grains were analysed. We analysed the rim, mantle, and the core of the grains. From the river sediments about 50 garnet grains were analysed from each sample. Here, we analysed the core and the rim. Measurement conditions are given in Table 1. The full database including lithology and metamorphic grade are included in the Supplementary data (see Appendix A). 
Table 1. Operating conditions of the electron microprobe for garnet analyses. Count time on the peak (in s), Bckg time counting time on background position (in s), $D L$ detection limit (in ppm).

\begin{tabular}{lllllllll}
\hline Spectrometer & 1 TAP & 1 TAP & 2 TAP & 3 PETJ & 4 PETJ & 4 PETJ & $5 \mathrm{LIFH}$ & $5 \mathrm{LIFH}$ \\
\hline $\begin{array}{llllllll}\text { Element } \\
\text { (Line) }\end{array}$ & $\mathrm{Si}(\mathrm{K} \alpha)$ & $\mathrm{Al}(\mathrm{K} \alpha)$ & $\mathrm{Mg}(\mathrm{K} \alpha)$ & $\mathrm{Ca}(\mathrm{K} \alpha)$ & $\mathrm{Ti}(\mathrm{K} \alpha)$ & $\mathrm{Cr}(\mathrm{K} \alpha)$ & $\mathrm{Mn}(\mathrm{K} \alpha)$ & $\mathrm{Fe}(\mathrm{K} \alpha)$ \\
Count time & 15 & 15 & 15 & 15 & 30 & 30 & 30 & 15 \\
Bckg time & 5 & 5 & 5 & 5 & 15 & 15 & 15 & 5 \\
Standard & Garnet, & Garnet, & $\mathrm{MgO}$, & $\mathrm{CaSiO}_{3}$, & $\mathrm{TiO}_{2}$, & $\mathrm{Cr}_{2} \mathrm{O}_{3}$, & Rhodonite, & $\mathrm{Fe}_{2} \mathrm{O}_{3}$, \\
& natural & natural & synthetic & natural & synthetic & synthetic & natural & synthetic \\
& 160 & 135 & 119 & 128 & 107 & 125 & 105 & 187 \\
\hline $\mathrm{DL}$ & 160 & & & & & & & \\
\hline
\end{tabular}

From all three valleys, the $63-125 \mu \mathrm{m}$ fraction of all river sediments were point counted and analysed by EMP. All hardrocks were analysed by EMP. From the Dorfertal valley four samples were chosen for a detailed study across five grain-size grades: from samples A2-5, A2-1, A2-8, and A2-4, all grain-size fractions were point counted while all grain-size fractions from samples A2-5, A2-1, and A2-4 were analysed by EMP. The database of garnets from all grain-size fractions is included in the Supplementary data (see Appendix A).

\subsubsection{Statistics}

For the graphical display of multivariate observations (points) and variables (lines) the compositional biplot is used. The length of the line corresponds to the variability of the respective element. The biplots are performed using CoDaPack, an open source software for Compositional Data Analysis (Comas-Cufi and Thió-Henestrosa, 2011). Principal component analysis (PCA) is based on log ratios following the methodology proposed by Aitchison (1986). In this study, centred log-ratio transformation (clr) was conducted for major elements and is illustrated in compositional biplots and also compositional ternary diagrams. 0.001 replaces very few zero values. Biplots serve as a valuable tool for estimating the potential for discrimination of a multivariate data set and its subsets (e.g., von Eynatten et al., 2003). 


\section{Results}

\subsection{Heavy mineral analysis $(63-125 \mu \mathrm{m})$}

Along the three different rivers, the dominant heavy minerals are the epidote group minerals (epidote, zoisite, clinozoisite). They represent between $4 \%$ and $90 \%$ of the transparent heavy mineral spectra (Fig. 3). Of these minerals zoisite is dominant in the samples of the Dorfertal and Frosnitztal valleys, and epidote is most frequent in the Timmeltal valley. In all samples, clinozoisite is less frequent than epidote and zoisite (see Appendix A). In most of the samples garnet is very prominent, ranging from $2 \%$ to $30 \%$ in the samples of the main rivers. In samples A3, A5-5 and A5-2 (tributaries of the main rivers) garnets represent between $0 \%$ and $8 \%$ of the heavy mineral spectra. In all samples, apatite (1-9\%), green calcic amphibole (1-14\%), staurolite $(0-6 \%)$, kyanite $(0-9 \%)$, and chloritoid $(0-11 \%)$ occur in varying percentages. The proportion of stable heavy minerals (zircon, rutile, and tourmaline) is generally low (max. 6.3\%). In some samples, titanite, sillimanite, amphiboles (other than green calcic amphibole) and pyroxene commonly occur in very minor proportions $(0-8 \%)$. Opaque minerals, micas, and alterites are not considered in Fig. 3. 


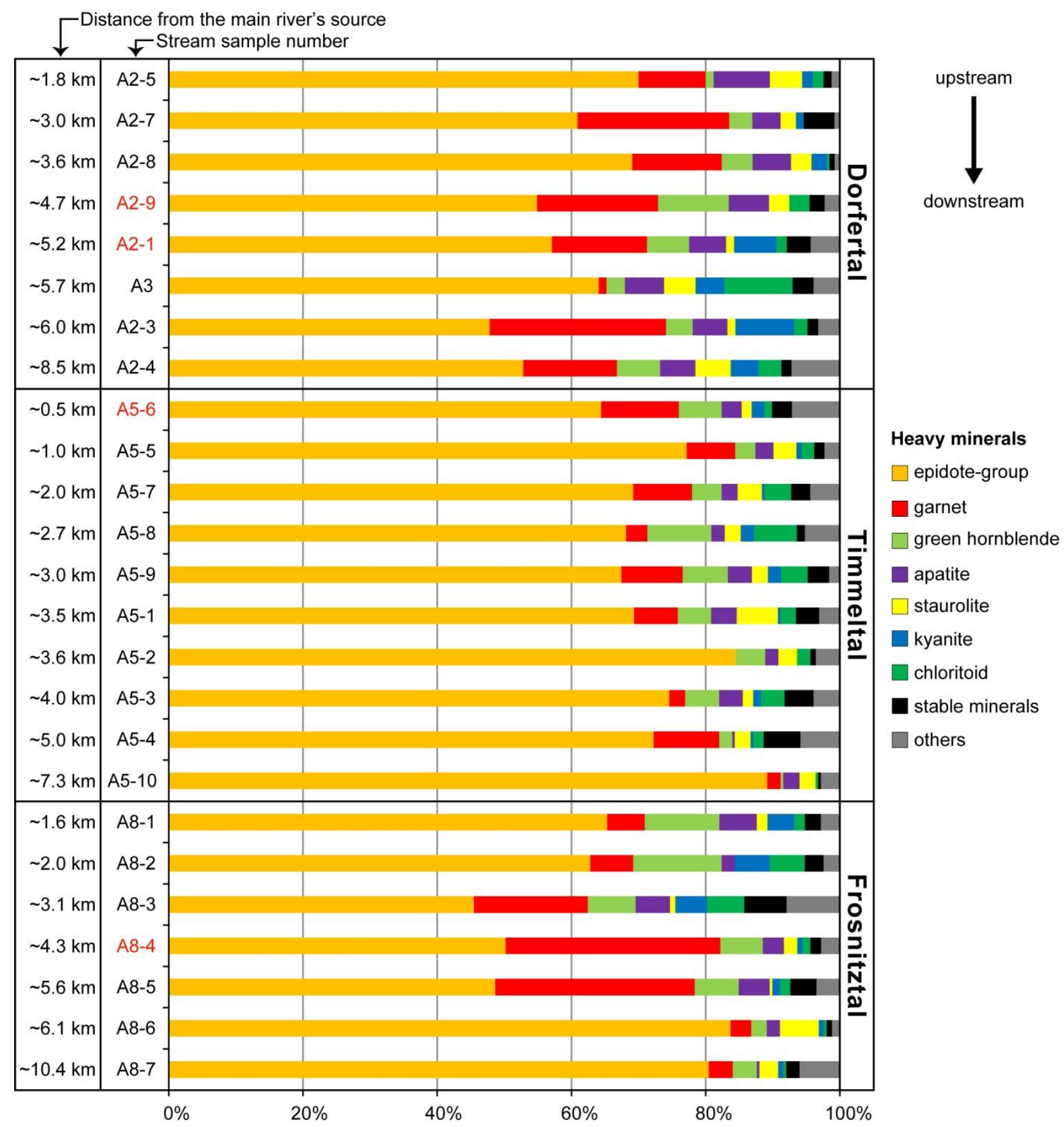

Fig. 3. Transparent heavy mineral spectra of the analysed samples $(63-125 \mu \mathrm{m})$ ordered from upstream to downstream for each valley. Numbers define the distance from the river's source in $\mathrm{km}$. Samples from the Eclogite Zone are red-coloured. Epidote-group: epidote, zoisite, clinozoisite; stable minerals: zircon, rutile, tourmaline; others: sillimanite, titanite, amphiboles (excluding green calcic amphibole), pyroxene, actinolite.

\subsection{Heavy mineral analysis vs. grain-size fraction (samples A2-5, A2-8, A2-1, A2-4 from the Dorfertal valley)}

The heavy mineral distribution in all samples and in all grain-size fractions remains essentially the same, with the dominant phases being epidote-group minerals and garnet (Fig. 4). Here, the 500-1000 $\mu \mathrm{m}$ grain-size fraction is not considered, because 
of the high proportion of micas and opaque minerals, which make up nearly $90 \%$ of the entire heavy mineral spectrum. Generally, the proportion of epidote-group minerals decreases from smaller to coarser grain-sizes, with the lowest concentration in the 250-500 $\mu \mathrm{m}$ grain-size fraction. Garnet generally increases from the smaller to the coarser grain-size fractions, with the highest proportion in the 125-250 $\mu \mathrm{m}$ (sample A2-1) or 250-500 $\mu \mathrm{m}$ (samples A2-5, A2-8, A2-4) grain-size fractions. Apatite, green calcic amphibole, staurolite, kyanite, and chloritoid also occur in all grain-size fractions with varying percentages. Similar to garnet, green calcic amphibole increases towards the coarser grain-size fractions, whereas apatite is more frequent in the smaller grain-size fractions. In all samples, staurolite and kyanite are most abundant in the 63-125 $\mu \mathrm{m}$ grain-size fraction. The proportion of stable minerals and minerals from the group named 'others' is generally low showing no clear trend related to grain size (Fig. 4). 


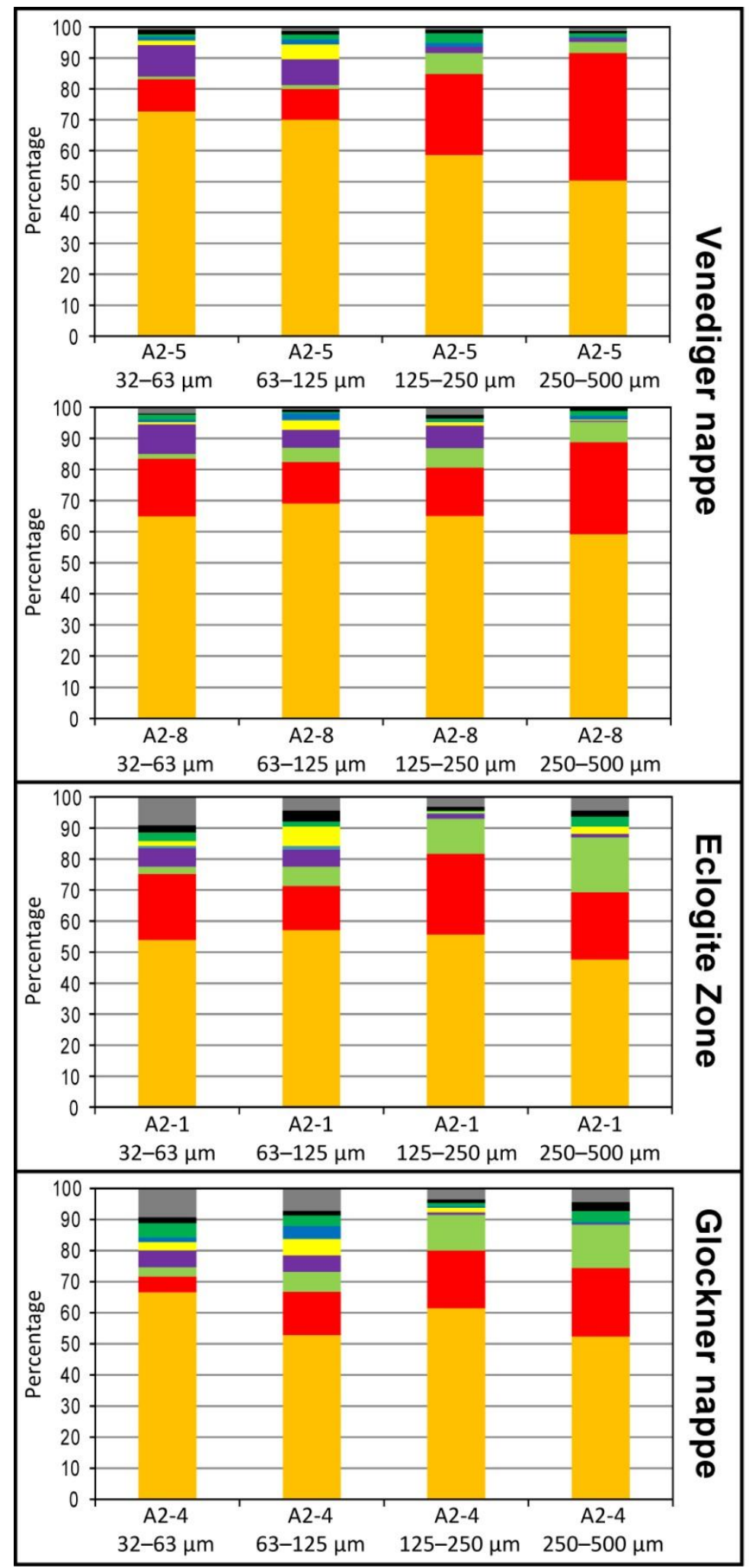

\section{Heavy minerals}

$\square$ others

- stable minerals

$\square$ chloritoid

kyanite

staurolite

apatite

green hornblende

garnet

epidote-group

Fig. 4. Heavy mineral distribution of four grain-size fractions $(32-63 \mu \mathrm{m}, 63-125 \mu \mathrm{m}, 125-250 \mu \mathrm{m}$, 250-500 $\mu \mathrm{m}$ ) of samples A2-5, A2-8 (Venediger nappe), A2-1 (Eclogite Zone), and A2-4 (Glockner nappe) from the Dorfertal valley. 


\subsection{Geochemistry of garnets $(63-125 \mu \mathrm{m})$}

Garnets from the three valleys cover a broad compositional range $\left(\mathrm{Alm}_{9-83} \mathrm{Sp}_{0.1-}\right.$ ${ }_{85} \mathrm{Gr}_{0.7-57} \mathrm{Py}_{0.5-40}$; see Appendix A). Most of the garnets, however, are Type B garnets, which are typically derived from amphibolite-facies metasedimentary rocks (Mange and Morton, 2007) (Fig. 5). Many garnets plot in field Ci, which are garnets derived from high-grade mafic rocks and some in field $\mathrm{Bi}$, typical for garnets derived from intermediate to felsic igneous rocks. In general, there is a good agreement of garnets derived from the river sediments with the garnets derived from the bedrock samples, as they show a high degree of overlap in the discrimination diagrams (Fig. 5). Some Type $D$ garnets, the field for garnets derived from metasomatic rocks, very-low grade metamafic rocks, or ultrahigh temperature metamorphosed calc-silicate granulites, are missing in the outcrop samples. We assume incomplete source rock sampling as the main reason for this discrepancy. 


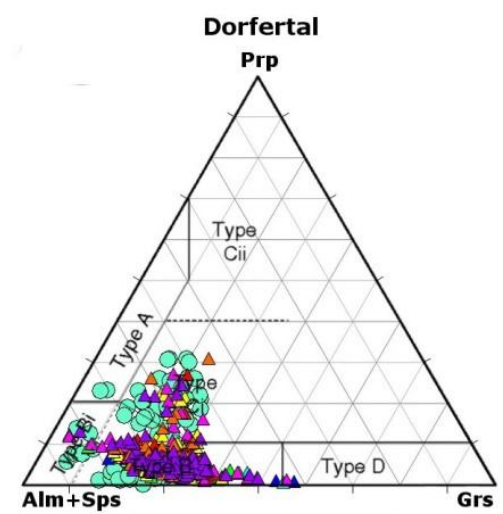

\begin{tabular}{|ll|}
\hline river sediments \\
$\Delta$ & $\mathrm{A} 2-5$ \\
$\Delta$ & $\mathrm{A} 2-7$ \\
$\Delta$ & $\mathrm{A} 2-8$ \\
$\triangle$ & $\mathrm{A} 2-10$ \\
$\Delta$ & $\mathrm{A} 2-9$ \\
$\Delta$ & $\mathrm{A} 2-1$ \\
$\Delta$ & $\mathrm{A} 2-3$ \\
$\Delta$ & $\mathrm{A} 2-4$ \\
$\mathrm{O}$ & $\mathrm{A} 3$ (affluent) \\
\hline
\end{tabular}

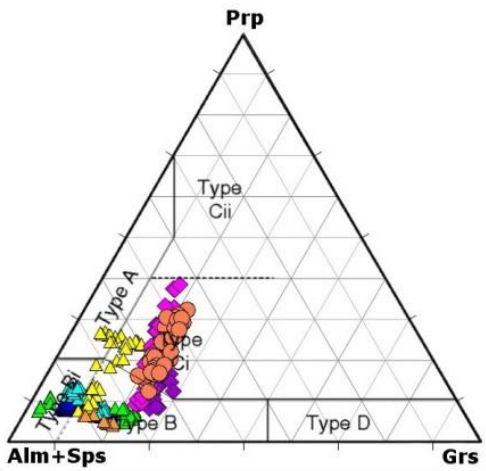

\section{hardrocks}

- Micaschist/Venediger nappe

$\triangle$ Micaschist/Venediger nappe Micaschist/Eclogite Zone

Micaschist/Eclogite Zone

Micaschist/Venediger nappe

Amphibolite pebble/Glockner nappe

Eclogite/Eclogite Zone

Micaschist/Venediger nappe

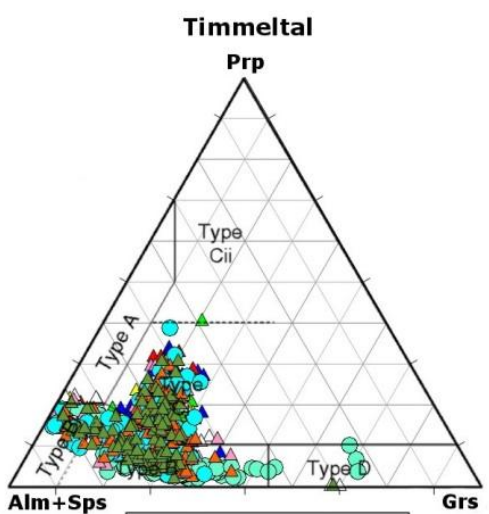

river sediments

$\Delta$ A5-6

$\triangle \quad$ A5-7

$\triangle \quad$ A5-8

$\Delta \quad$ A5-9

$\triangle \quad$ A5-1

A5-2 (affluent)

$\triangle \quad$ A5-3

A5-5 (affluent)

$\triangle \quad$ A5-4

$\triangle \quad$ A5-10

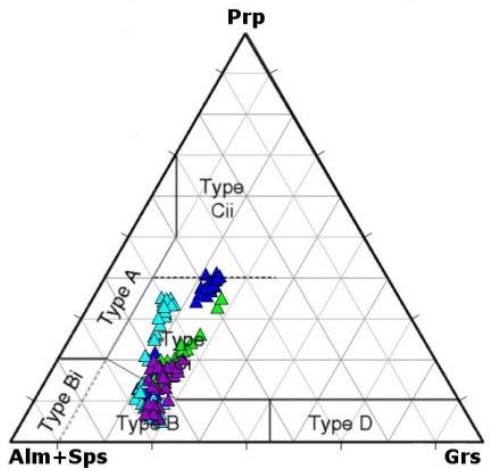

hardrocks

Grs

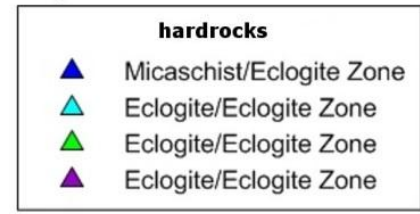

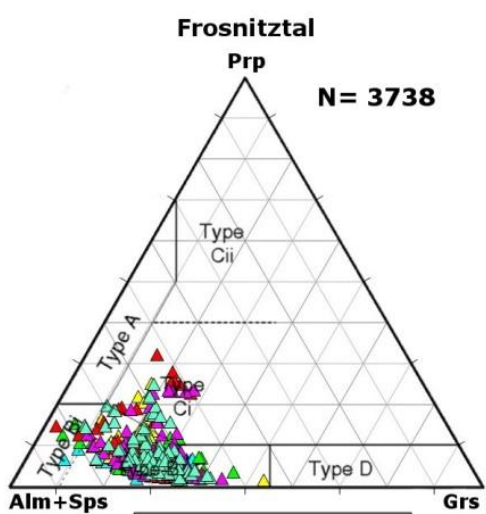

river sediments

$\Delta$ A8-1

$\triangle \quad$ A8-2

$\triangle \quad A 8-3$

$\triangle \quad A 8-4$

$\Delta \quad$ A8-5

$\triangle \quad$ A8-6

$\triangle \quad A 8-7$

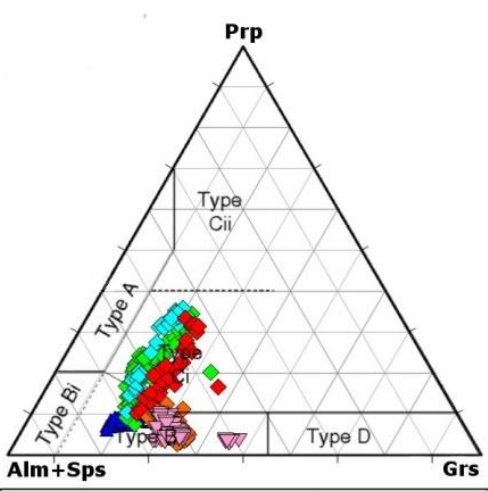

Alm+Sps

hardrocks

- Micaschist/Eclogite Zone

$\triangle$ Metasediment/Venediger nappe

$\checkmark$ Eclogite/Eclogite Zone

$\checkmark$ Eclogite/Eclogite Zone

- Eclogite/Eclogite Zone

Eclogite/Venediger nappe

$\nabla \quad$ Metabasite/Venediger nappe

Fig. 5. Composition of garnets in the ternary classification diagram of Mange and Morton (2007) with almandine+spessartine, grossular and pyrope as poles. Composition of detrital garnets from all river sediments from each valley (63-125 $\mu \mathrm{m})$ and of garnets from the bedrock samples from each valley. A - mainly from high-grade granulite-facies metasedimentary rocks or charnockites and intermediate felsic igneous rocks, $\mathrm{B}$ - amphibolite-facies metasedimentary rocks, $\mathrm{Bi}$ - intermediate to felsic igneous rocks, $\mathrm{Ci}$ - mainly from high-grade mafic rocks, Cii - ultramafics with high $\mathrm{Mg}$ (pyroxenites and peridotites), D - metasomatic rocks, very low-grade metamafic rocks and ultrahigh-temperature metamorphosed calc-silicate granulites.

Garnet composition from all stream sediments (63-125 $\mu \mathrm{m})$ upstream of the Eclogite Zone, within the Eclogite Zone, and downstream of the Eclogite Zone exhibit distinct contrasts (Fig. 6). Nearly all of the garnets (98\%) upstream of the Eclogite Zone are 
type $B$, the field for garnets derived from amphibolite-facies sedimentary rocks. Garnets from sediment sampled within the Eclogite Zone are either type B garnets (74\%) or type Ci garnets (33\%), the latter being typically derived from high-grade metamorphic rocks. Few garnets $(3 \%)$ plot in field $\mathrm{Bi}$, which is the field for garnets derived from intermediate felsic igneous rocks. Most of the garnets from samples downstream of the Eclogite Zone are type B (55\%), but many are type C (43\%). There are also a small number of type $\mathrm{D}$ garnets $(0.5 \%)$, which have a high $\mathrm{CaO}$ component (Fig. 6).
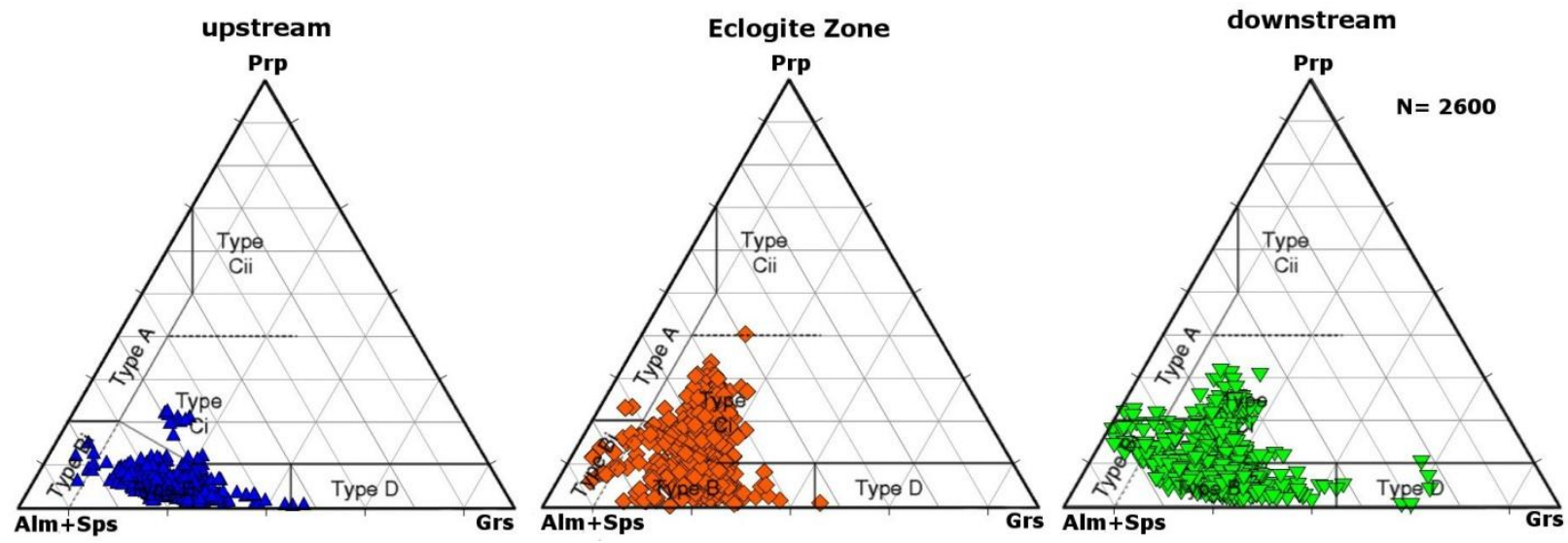

Fig. 6. Composition of detrital garnets $(63-125 \mu \mathrm{m})$ in the ternary classification diagram of Mange and Morton (2007) with almandine+spessartine, grossular and pyrope as poles. Each diagram shows garnet compositions from all three rivers, divided into (i) upstream of the Eclogite Zone, (ii) within the Eclogite Zone, and (iii) downstream of the Eclogite Zone. For key to garnet compositional fields see Fig. 5.

For the biplots, major elements $\mathrm{SiO}_{2}, \mathrm{Al}_{2} \mathrm{O}_{3}, \mathrm{CaO}, \mathrm{MgO}, \mathrm{MnO}$ and $\mathrm{FeO}$ are used to differentiate the garnets from the different rock types and sediments of the different nappes. For the compositional ternary plots the major elements $\mathrm{CaO}, \mathrm{MgO}$, and $\mathrm{MnO}$ are used, because they show the highest variability. The biplots are defined by the first and the second principal components (PC). $\mathrm{SiO}_{2}$ and $\mathrm{Al}_{2} \mathrm{O}_{3}$ show the lowest variation in all sample sets. The small distance between $\mathrm{SiO}_{2}$ and $\mathrm{Al}_{2} \mathrm{O}_{3}$ indicates relatively constant $\mathrm{SiO}_{2} / \mathrm{Al}_{2} \mathrm{O}_{3}$ values. $\mathrm{FeO}$ also shows low variation. The major elements $\mathrm{CaO}, \mathrm{MgO}$, and $\mathrm{MnO}$ show a comparably high variability (spread in different directions) (Fig. 7a, b). While $\mathrm{MnO}$ and $\mathrm{MgO}$ dominate principle component 1 (PC1), in opposite direction $\mathrm{CaO}$ has the highest loading on principle component 2 (PC2). 
Micaschists of the Venediger nappe (blue points) accumulate in the direction of $\mathrm{FeO}$. Also, garnets from micaschists of the Eclogite Zone (red points) are concentrated in this direction, although some accumulate between the arrows of $\mathrm{MgO}$ and $\mathrm{CaO}$ (red points). Garnets from rocks of the Venediger nappe (green, light grey, and grey points) concentrate in the direction of $\mathrm{CaO}$. Garnets from the eclogites of the Eclogite Zone (magenta points) and also from the amphibolite pebble (yellow points), found in the Glockner nappe, accumulate mainly in the centre (Fig. 7a). The compositional ternary plot also demonstrates that garnets from the micaschists have a slightly higher $\mathrm{MnO}$ content in contrast to the garnets from the other rocks, even though some garnets from micaschists of the Eclogite Zone show higher MgO contents. Garnets from rocks of the Venediger nappe (eclogites, metabasites, metasediments) are enriched in $\mathrm{CaO}$. Garnets from the metamafic rocks of the Eclogite Zone and of the amphibolite pebble (derived either from the Venediger nappe or Eclogite Zone) tend to higher $\mathrm{MgO}$ contents (Fig. 7c).

Interestingly, garnets measured in the micaschists show a high degree of overlap, regardless whether they are from the Venediger nappe or Eclogite Zone. Some of the garnets from the micaschists of the Eclogite Zone tend towards $\mathrm{MgO}$, which is probably due to the fact that rocks of the Eclogite Zone suffered higher metamorphic conditions and produce garnets with higher MgO contents (e.g., Wright, 1938, Morton, 1985, Deer et al., 1992 and Krippner et al., 2014). It is also interesting that garnets from rocks of the Venediger nappe (excluding the micaschists) form a group arranged at the $\mathrm{CaO}$ line. They can be clearly separated from the other garnets. In this context, an important observation is that garnets from the eclogite of the Venediger nappe (green points) have a higher $\mathrm{CaO}$ component than garnets from the eclogites sampled within the Eclogite Zone, which are richer in $\mathrm{MgO}$, and can be clearly separated from each other. It is not clear from which unit the amphibolite pebble is derived, but due to the fact that they have similar composition to the garnets from the eclogites of the Eclogite Zone, it is probable that this amphibolite is derived from the Eclogite Zone.

For a better overview, all garnets measured in the outcrop samples from all samples from the three valleys and all garnets measured in the river samples are plotted together in a biplot and compositional ternary plot in order to test the degree of overlap (Fig. 7b, d). Overall, most of the garnets from the outcrops and river sediments are arranged along the line from $\mathrm{CaO}$ to more $\mathrm{MgO}$-rich garnets (Fig. $7 \mathrm{~d}$ ) 
and show a high degree of overlap. The detrital garnets show a wider distribution than the garnets of the outcrops because there are more data points of garnets measured in the sediments. However, there are some groups of detrital garnets which cannot be linked to the outcrop samples (Fig. 7b, d), possibly because of incomplete source rock sampling. Differences between the geochemistry of garnet cores and rims are only marginally significant. Most of the garnets show a gradational zoning with a slight increase of $\mathrm{MgO}$ towards the rim. 


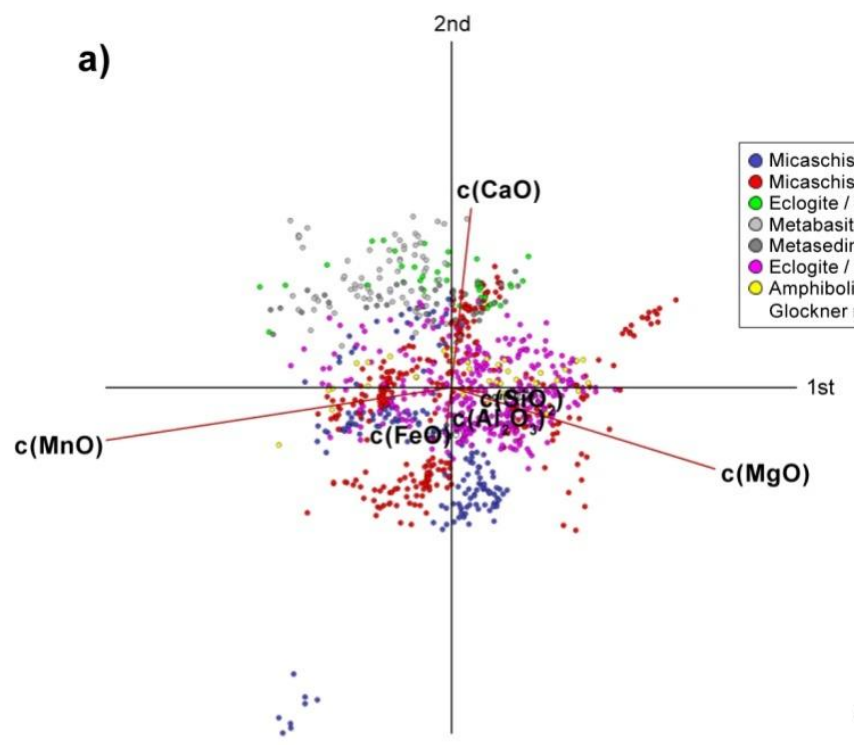

c)
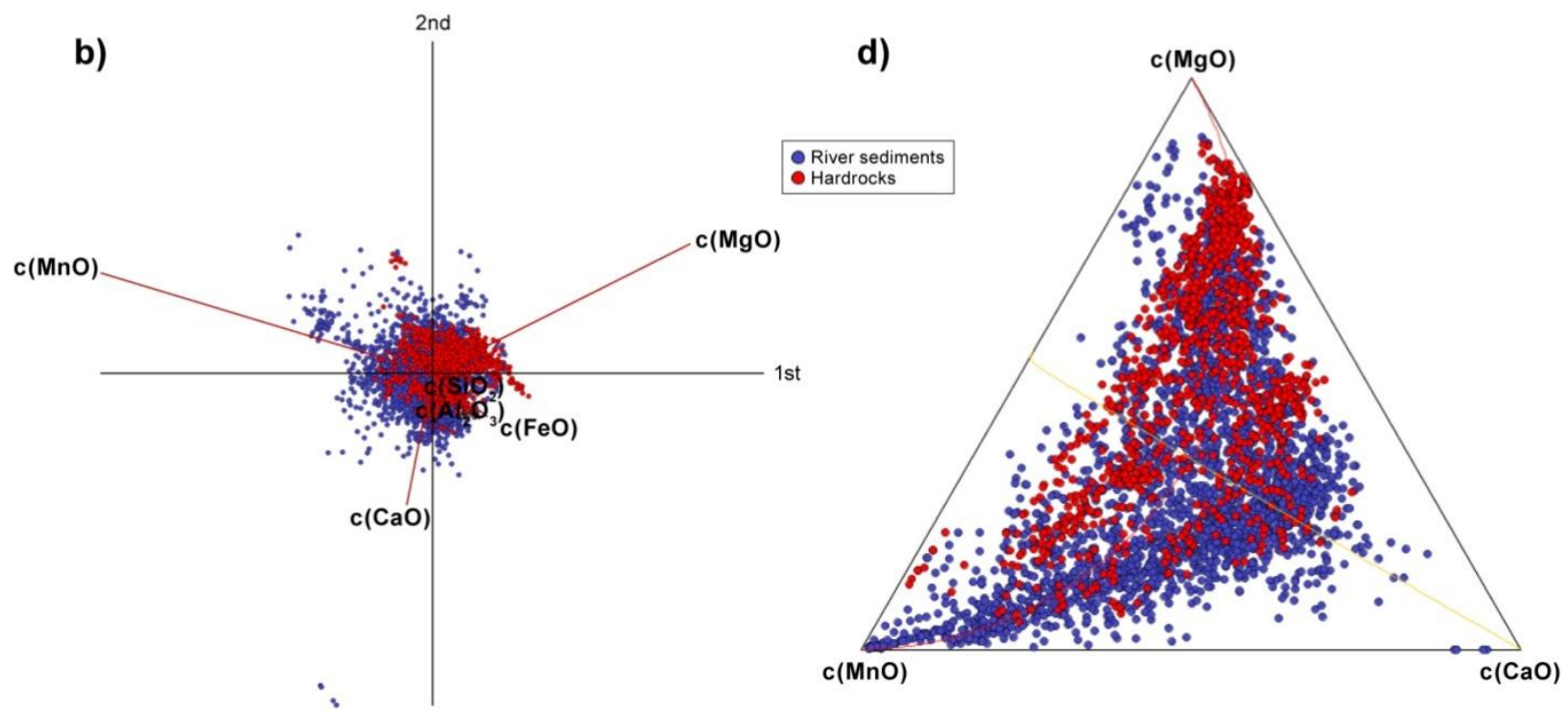

Fig. 7. a) Compositional biplot of garnet grains from all bedrock samples from every valley for the major elements $\mathrm{SiO}_{2}, \mathrm{Al}_{2} \mathrm{O} 3, \mathrm{CaO}, \mathrm{FeO}, \mathrm{MnO}$, and $\mathrm{MgO}$. Axes are first and second principal components (PC). Almost $92 \%$ of the variability is explained by the first and second PC.b) Compositional biplot of garnet grains from all bedrock and river sediments samples from every valley for the major elements $\mathrm{SiO}_{2}, \mathrm{Al}_{2} \mathrm{O} 3, \mathrm{CaO}, \mathrm{FeO}, \mathrm{MnO}$, and $\mathrm{MgO}$. Axes are first and second principal components. Almost $81 \%$ of the variability is explained by the first and second PC. c) Centred ternary plot of garnet grains from all bedrock samples from every valley for the major elements $\mathrm{CaO}, \mathrm{MnO}$, and $\mathrm{MgO}$ with highest probability. d) Centred ternary plot of garnet grains from all bedrock and river sediments samples from every valley for the major elements $\mathrm{CaO}, \mathrm{MnO}$, and $\mathrm{MgO}$ with highest probability. 


\subsection{Geochemistry of garnets from different grain-size fractions from the}

Dorfertal valley

Almost all garnets of all grain-size fractions from sample A2-5 are type B garnets (98.5\%), except for very few type Bi garnets and some type $D$ garnets. Towards the smaller grain-size fraction an increasing number of garnets with a higher grossularcomponent (up to $\sim 60 \%$ ) is observed, while in the 250-500 $\mu \mathrm{m}$ and 500-1000 $\mu \mathrm{m}$ fractions the grossular-component does not exceed 36\% (Fig. 8; see also Appendix A). 

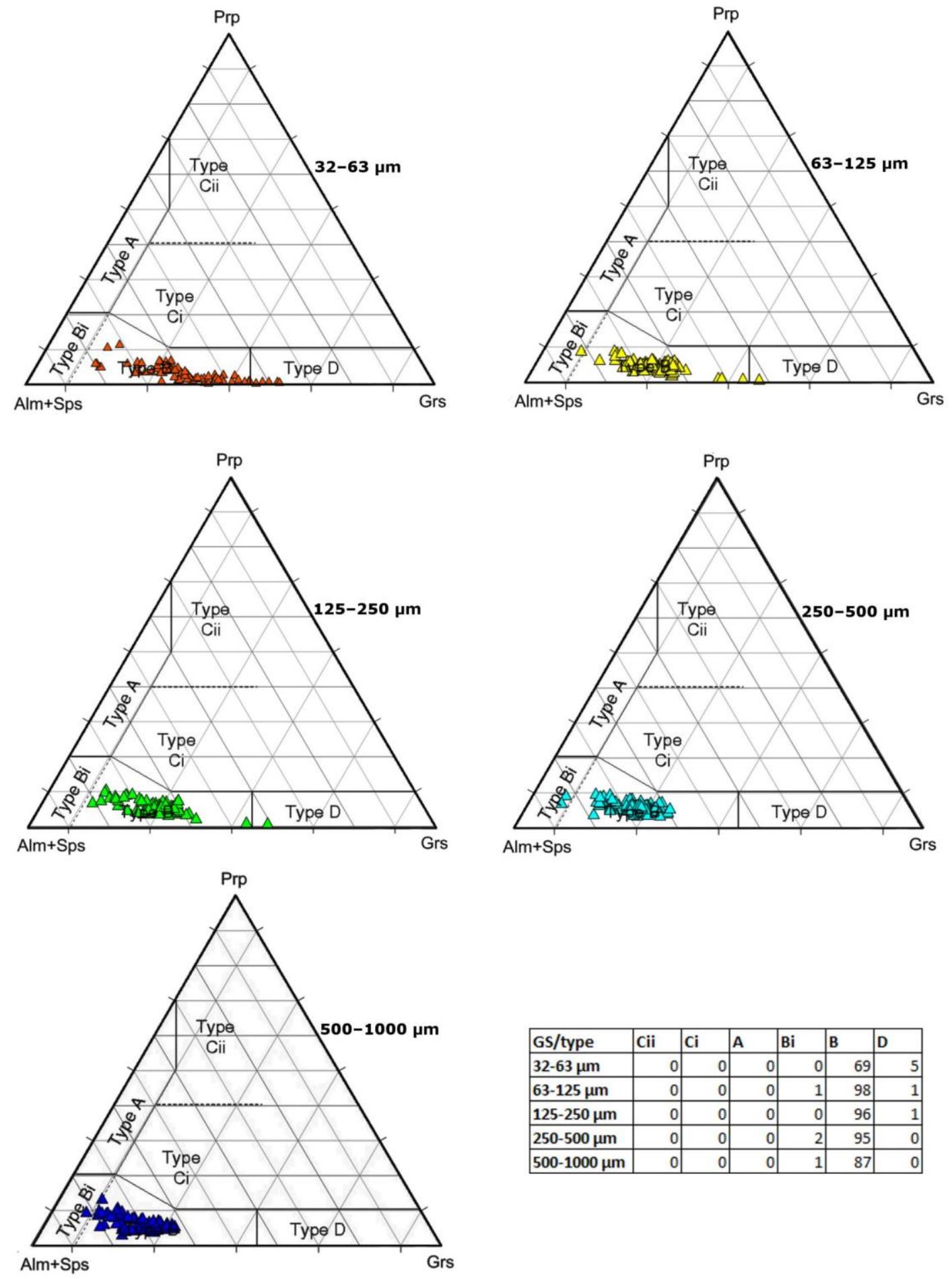

\begin{tabular}{|l|r|r|r|r|r|r|}
\hline GS/type & Cii & Ci & A & Bi & B & D \\
\hline $\mathbf{3 2 - 6 3 \mu \mathrm { m }}$ & 0 & 0 & 0 & 0 & 69 & 5 \\
\hline $\mathbf{6 3 - 1 2 5} \mu \mathrm{m}$ & 0 & 0 & 0 & 1 & 98 & 1 \\
\hline $\mathbf{1 2 5}-250 \mu \mathrm{m}$ & 0 & 0 & 0 & 0 & 96 & 1 \\
\hline $250-500 \mu \mathrm{m}$ & 0 & 0 & 0 & 2 & 95 & 0 \\
\hline $\mathbf{5 0 0 - 1 0 0 0 \mu \mathrm { m }}$ & 0 & 0 & 0 & 1 & 87 & 0 \\
\hline
\end{tabular}

Fig. 8. Composition of detrital garnets from the different grain-size fractions in sample A2-5 (upstream of the Eclogite Zone) in the ternary classification diagram of Mange and Morton (2007) with almandine+spessartine, grossular and pyrope as poles. For key to garnet compositional fields see Fig. 5. Table shows content of the garnet types in the different grains-size fractions (GS).

Most of the garnets of all grain-size fractions from sample A2-1 plot in field B $(87 \%)$. However, an input of type $\mathrm{Ci}$ garnets in all grain-size fractions can be observed 
(10\%). In the $250-500$ and $500-1000 \mu \mathrm{m}$ grain-size fractions the proportion of grossular accounts for no more than $43 \%$ and $33 \%$ of garnets respectively, whereas in the smaller grain-size fractions $(32-250 \mu \mathrm{m})$ the proportion of grossular of some garnets is around $50-56 \%$ (see Appendix A). It is noticeable that in the $125-250 \mu \mathrm{m}$ grain-size fraction the proportion of pyrope in type $\mathrm{Ci}$ garnets is low (no more than $16 \%)$ compared with other grain-size fractions. In the coarser grain-size fractions $(250-500 \mu \mathrm{m})$ the pyrope component reaches up to $34 \%$ (Fig. 9; see also Appendix A). 

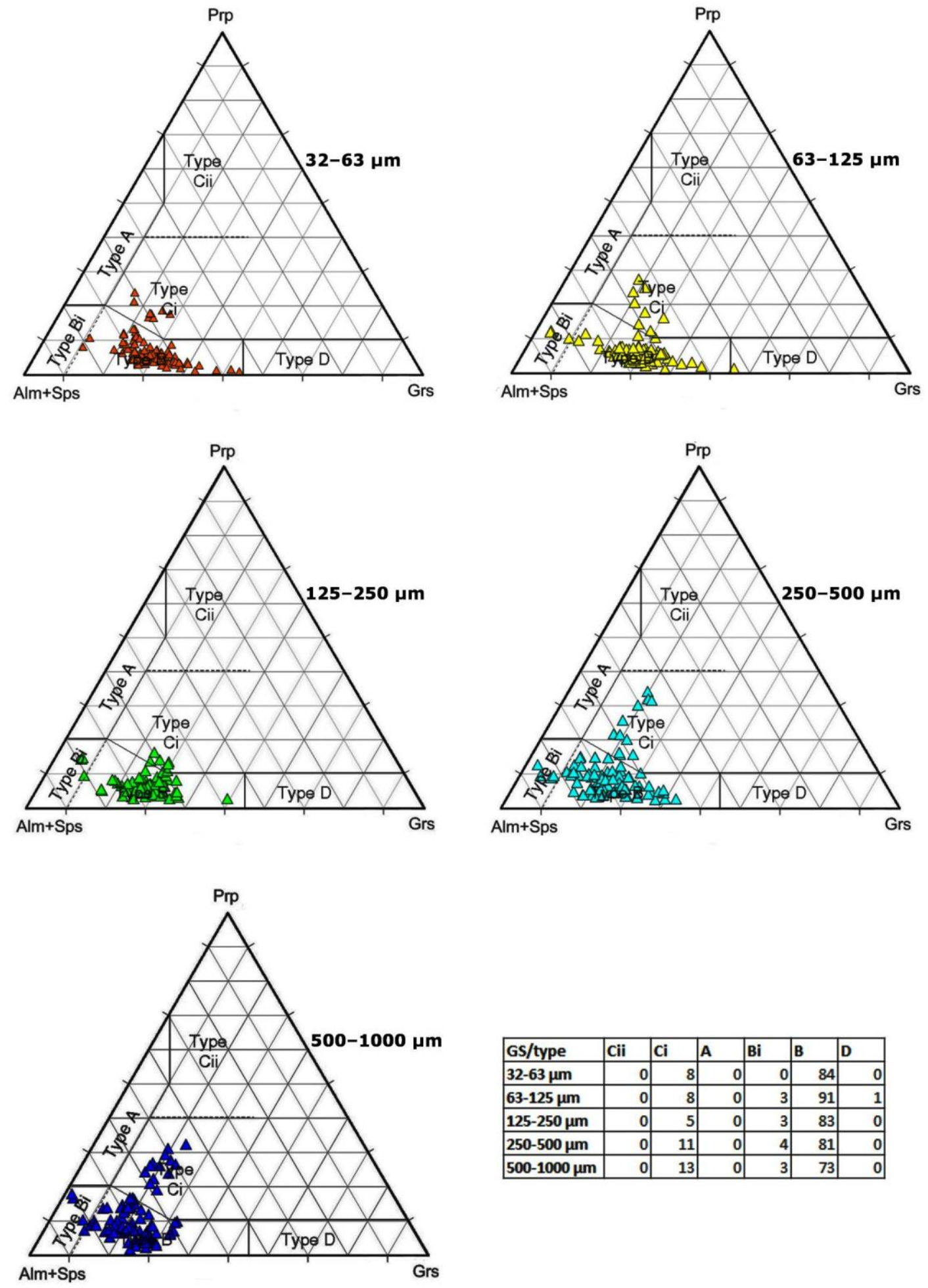

\begin{tabular}{|l|r|r|r|r|r|r|}
\hline GS/type & Cii & Ci & A & \multicolumn{1}{|l|}{ Bi } & B & D \\
\hline $32-63 \mu \mathrm{m}$ & 0 & 8 & 0 & 0 & 84 & 0 \\
\hline $63-125 \mu \mathrm{m}$ & 0 & 8 & 0 & 3 & 91 & 1 \\
\hline $125-250 \mu \mathrm{m}$ & 0 & 5 & 0 & 3 & 83 & 0 \\
\hline $250-500 \mu \mathrm{m}$ & 0 & 11 & 0 & 4 & 81 & 0 \\
\hline $500-1000 \mu \mathrm{m}$ & 0 & 13 & 0 & 3 & 73 & 0 \\
\hline
\end{tabular}

Fig. 9. Composition of detrital garnets from the different grain-size fractions from sample A2-1 (within the Eclogite Zone) in the ternary classification diagram of Mange and Morton (2007) with almandine+spessartine, grossular and pyrope as poles. For key to garnet compositional fields see Fig. 5. Table shows content of the garnet types in the different grains-size fractions (GS).

Most of the garnets of all grain-size fractions from sample A2-4 plot in field B $(84.5 \%)$, with a subordinate number in field $\mathrm{Ci}(11 \%)$, and very few in field $\mathrm{Bi}(3 \%)$. 
Garnets with higher grossular contents are more frequent in the smaller grain-size fractions, especially in the $32-63 \mu \mathrm{m}$ grain-size fraction. In this sample type $D$ garnets are only found in the $32-63 \mu \mathrm{m}$ grain-size fraction. Pyrope-rich garnets are more frequent in the coarser grain-size fractions (250-500 and 500-1000 $\mu \mathrm{m})$, where they reach up to $38 \%$. In the smaller grain-size fractions (32-63 and 63-125 and $125-250 \mu \mathrm{m}$ ), the proportion of grossular is not higher than $29 \%$. In this sample $69 \%$ of all type $\mathrm{Ci}$ garnets measured in the sample are found in the 250-500 and 500$1000 \mu \mathrm{m}$ grain-size fractions (Fig. 10). 

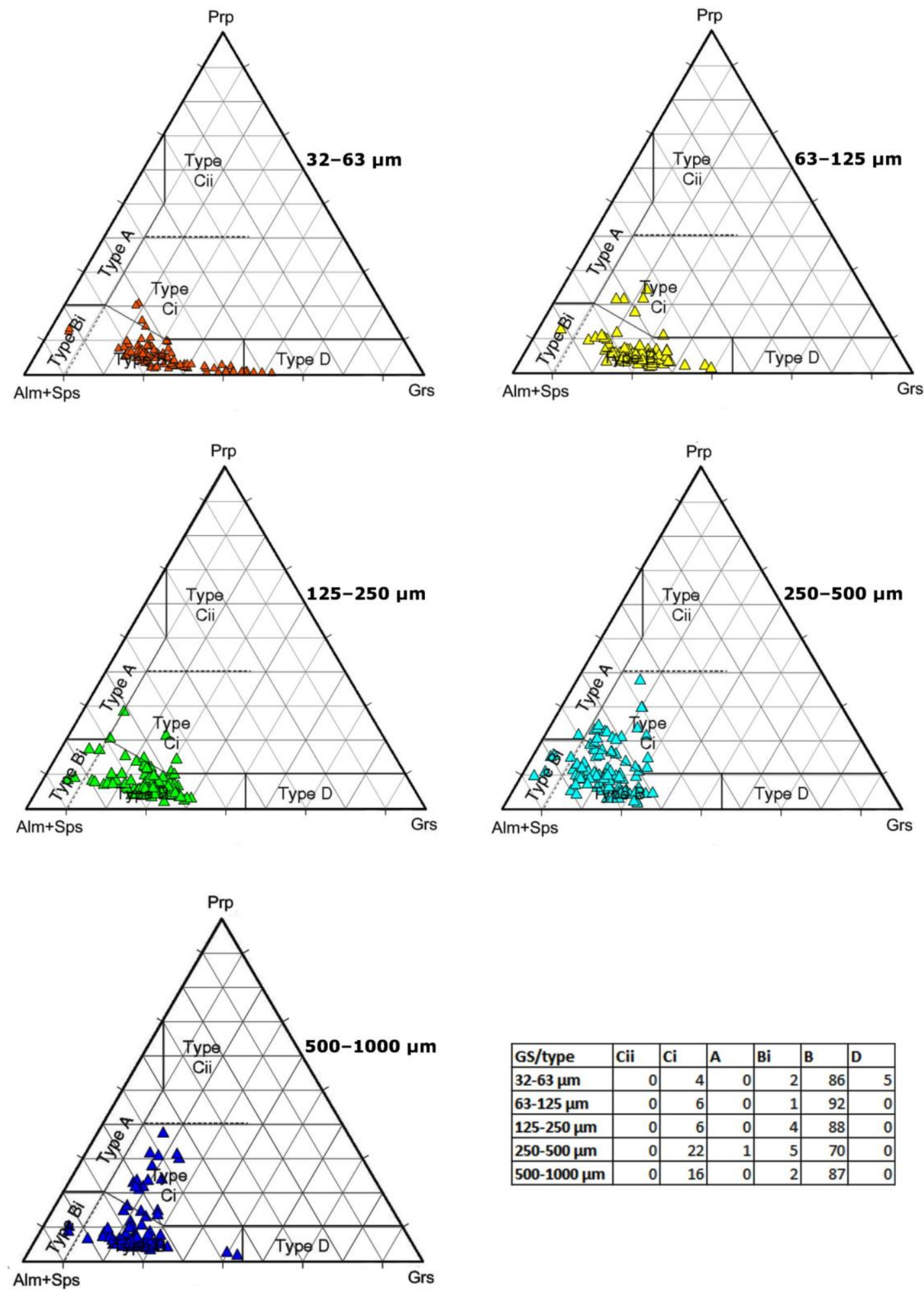

\begin{tabular}{|l|r|r|r|r|r|r|}
\hline GS/type & Cii & Ci & A & \multicolumn{1}{l|}{ Bi } & B & D \\
\hline $\mathbf{3 2 - 6 3} \boldsymbol{\mu m}$ & 0 & 4 & 0 & 2 & 86 & 5 \\
\hline $\mathbf{6 3 - 1 2 5} \boldsymbol{\mu m}$ & 0 & 6 & 0 & 1 & 92 & 0 \\
\hline $\mathbf{1 2 5}-250 \mu \mathrm{m}$ & 0 & 6 & 0 & 4 & 88 & 0 \\
\hline $250-500 \mu \mathrm{m}$ & 0 & 22 & 1 & 5 & 70 & 0 \\
\hline $\mathbf{5 0 0 - 1 0 0 0} \boldsymbol{\mu m}$ & 0 & 16 & 0 & 2 & 87 & 0 \\
\hline
\end{tabular}

Fig. 10. Composition of detrital garnets from the different grain-size fractions from sample A2-4 (downstream the Eclogite Zone) in the ternary classification diagram from Mange and Morton (2007) with almandine+spessartine, grossular and pyrope as poles. For key to garnet compositional fields see Fig. 5. Table shows content of the garnet types in the different grains-size fractions (GS).

The composition of all garnets from the different grain-size fractions from all samples are plotted together in a compositional ternary diagram (Fig. 11). There is a high 
overlap of garnets from the different grain-sizes. Most of the garnets accumulate in the centre and in the lower half of the diagram, but it is apparent that $\mathrm{CaO}$-rich garnets are more frequent in the finer grain-size fractions, whereas $\mathrm{MgO}$-rich garnets are more frequent in the coarser grain-size fractions (Fig. 11).

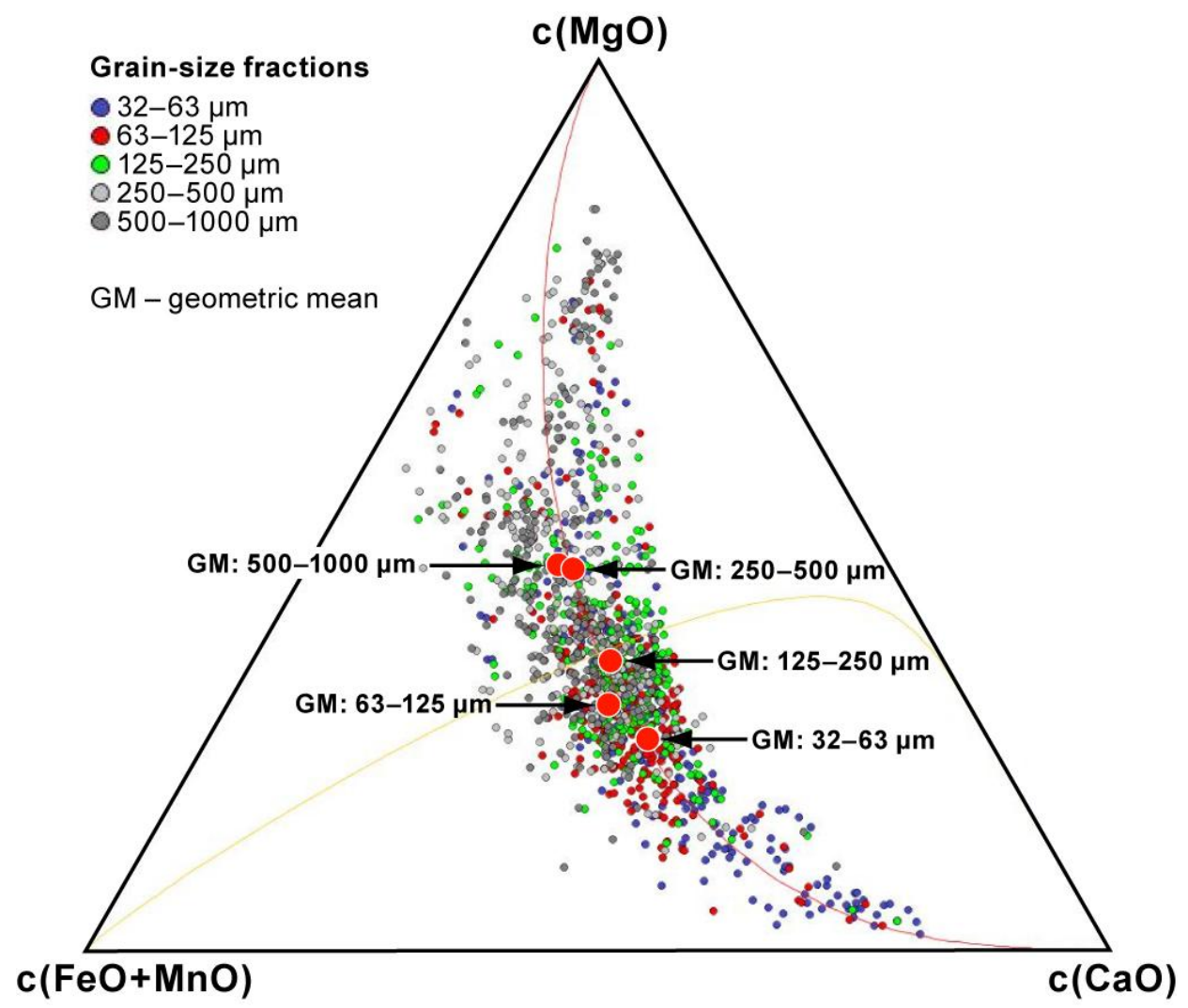

Fig. 11. Centred ternary plot of detrital garnet grains from the different grain-size fractions of all samples (A2-5, A2-1, A2-4) from the Dorfertal valley for the major elements $\mathrm{CaO}, \mathrm{FeO}+\mathrm{MnO}$, and $\mathrm{MgO}$ with highest probability. GM: geometric mean.

\section{Discussion}

The heavy mineral assemblages and garnet geochemical data reflect the geological setting of the study area, but the results demonstrate grain-size control on sediment composition including single-grain compositional variations.

The heavy mineral assemblages show a dominance of epidote-group minerals, garnet, and green calcic amphibole, which are commonly found in sediments derived from collisional orogens such as the Alps (Garzanti et al., 2007). Along the three different valleys, the heavy mineral association of the 63-125 $\mu \mathrm{m}$ grain-size fraction remains essentially similar with only minor variations. Most of the rocks of each nappe contain epidote and zoisite, which explains the high input of this mineral group 
(see Appendix A). Also garnet is a common mineral in most of the rocks. Green calcic amphibole is found in high amounts in rocks of the Lower Schieferhülle and in the metasedimentary rocks of the Eclogite Zone (see Appendix A). All other minerals are only found in specific rocks in minor concentrations and therefore their relative abundances are heavily influenced by the high input of epidote-group minerals. Generally, the zircon-tourmaline-rutile (ZTR) index (Hubert, 1962) of the river sediments is low $(Z T R=0.4-6.3 \%)$. Two samples from the tributaries of the main rivers (sample A3 from the Dorfertal valley and sample A5-2 from the Timmeltal valley) carry only a few or no garnet grains. This is interpreted as due to the fact that both rivers drain only a small part of the Glockner nappe (Fig. 2), which comprises only a few garnet-bearing rocks, causing garnet contents to be diluted by the high input of epidote-group minerals. Garnet grains in the heavy mineral assemblage from sample A5-5, which is also a sample of a tributary from the main stream of the Timmeltal valley, make up $\sim 7 \%$ of the spectrum. This tributary drains the Eclogite Zone and garnet grains from the eclogite lenses can be supplied to the tributary (Fig. 2). Garzanti et al. (2010) studied the relationship between source rocks and heavy mineral concentration with the result that ultradense rocks such as eclogites provide a high input of heavy minerals, which point to their occurrences, even though overprinted by retrogression. In the Tauern window, embedded metaophiolites are common and represent a source for rich heavy mineral suites which are either epidote-dominated or amphibole-dominated, with garnet, often dominated in extremely rich heavy minerals suites (Garzanti et al., 2010). A high input of garnets is observed in sample A8-4 of the Frosnitztal valley, where the river drains the Eclogite Zone. The high input of epidote minerals probable reflects greenschist-facies conditions in the source area, and greenschist-facies retrogression in the Eclogite Zone. The same observations were made in the Sesia-Lanzo area (Garzanti et al., 2010). Due to the probable high input of epidote-group minerals, garnet and amphibole, other minerals may also be diluted.

Comparing other grain-size fractions, in all samples apatite is more frequent in the smaller grain-size fractions and green calcic amphibole is more frequent in the coarser grain-size fractions (Fig. 4). This is unlikely to be due to hydrodynamic fractionation since the two minerals have similar densities. The difference is therefore likely to be attributable to grain-size inheritance from the source rocks, with apatite grain-sizes being generally smaller than green calcic amphibole. In all grain-size 
fractions the heavy mineral assemblages reflect the geological situation in the source area, but in some grain-size fractions minerals of lesser amounts may completely disappear particularly in the coarser grain-size fractions. The highest variety of heavy minerals is found in the commonly used grain-size fraction of $63-125 \mu \mathrm{m}$, which demonstrates the usefulness of this grain-size window. However, the geochemistry of garnets reveals a different picture as discussed below.

The garnet geochemistry of all sediments from the three rivers show a relatively uniform pattern, with all garnets plotting either in field B, Bi, or $\mathrm{Ci}$ (Fig. 5 and Fig. 6). This pattern is consistent with the garnet geochemistry of the bedrock found in the study area, which suffered greenschist- to amphibolite-facies metamorphism, and up to eclogite-facies metamorphism within the Eclogite Zone. However, there are some type $D$ garnets in the sediments which are not evident in the underlaying bedrock. These can be probably linked to the serpentinite bodies exposed in the Glockner nappe. The serpentinite bodies are surrounded by Ca-rich metasedimentary rocks (Dietrich et al., 1986 and Dachs et al., 2005). At the contact zone to these metasedimentary rocks, a rodingite serie is exposed which contains grossular-rich garnets (Dietrich et al., 1986 and Dachs et al., 2005).

The detrital garnet compositions in samples from the Venediger nappe upstream of the Eclogite Zone can be linked to metasedimentary rocks and amphibolites which suffered amphibolite-facies metamorphism. The very few type Bi garnets can also be linked to these rocks, but may be also derived from Variscan granitoids which have intruded the pre-Variscan basement of the Venediger nappe (Cesare et al., 2001). The few $\mathrm{Ci}$ type garnets are probably derived from pre-Alpine eclogites exposed in that area. There is an increase in the quantity of pyrope-rich garnet within the Eclogite Zone, indicating input from the eclogites of this Zone. Farther downstream, the pattern reflects the composition of garnets from rocks found upstream of and within the Eclogite Zone (Fig. 6).

The results show that the geochemistry of garnets strongly reflects the geological situation in the source area, as the composition reflects the different metamorphic conditions in the several units, which confirms the application of garnet geochemistry in sedimentary provenance analysis. Interestingly, garnet compositions in the two types of eclogites (pre-Alpine vs. Alpine) are different, as the high $\mathrm{MgO}$ content in the garnets in the Alpine eclogites indicates high pressure and temperature conditions, 
which are not evident in the Venediger nappe, and therefore demonstrate the different evolution of these eclogites.

The garnet composition of the different grain-size fractions from the three samples from the Dorfertal valley also reflects the geological situation in this area. Almost all the garnets of sample A2-5 from the Venediger nappe plot in field B (Fig. 8). Here, an input of garnets derived from the pre-Alpine eclogites is not visible. Within the Eclogite Zone there is an input of pyrope-rich garnets derived from the eclogites (Fig. 9), and garnets from sample A2-4 downstream of the Eclogite Zone reflect the pattern from upstream and directly from the Eclogite Zone (Fig. 10). But a closer look at the different grain-size fractions reveals that the very few type $D$ garnets are more frequent in the smaller grain-size fractions (32-63 and 63-125 $\mu \mathrm{m}$ ), and pyrope-rich garnets are more frequent in the coarser grain-size fractions, especially in the 250500 and 500-1000 $\mu \mathrm{m}$ grain-size fractions (Fig. 11). The grain-size of pyrope-rich garnets in the eclogites of the Hohe Tauern area is almost always coarser than $400 \mu \mathrm{m}$ (see Appendix A). Pyrope-rich garnets are therefore more frequent in the coarser grain-size fractions and relatively poorly represented in the smaller grain-size fractions, a pattern best illustrated by sample A2-4 (Fig. 10). Although, in general, the heavy mineral assemblages and garnet composition in the sediments reflect very well the conditions in the source area, great care must be taken when only considering a narrow grain-size window, because some important information may get lost, especially if some rocks are only minor distributed and only produce minerals with a special grain-size, which do not occur in the analysed grain-size window. This demonstrates the role played by grain-size inheritance from source to sediment. Another statement can be made about the sampling. An influence of preAlpine eclogites is not visible in all samples, independently of the grain-size range. Therefore, to obtain a complete picture of the geological framework not only the grain-size, but also the number of samples is of importance.

\section{Conclusions}

Our results underline the reliability of heavy minerals and garnet geochemistry in sedimentary provenance analysis. The most important findings of this study are as followed:

- The sediments of the three valleys from the Hohe Tauern area show a dominance of epidote-group minerals and garnets in all grain-size fractions, 
which can be related to the greenschist-facies metamorphic conditions in the source area as well as greenschist-facies retrogression and to the possibly high input of heavy mineral suites derived from ultradense source rocks.

- An increase of apatite in the fine tail of the size distribution (32-63 $\mu \mathrm{m})$ and an increase of green calcic amphibole and garnet in the coarse tail of the size distribution can be observed, probably related to mineral grain-sizes in the source rocks.

- Detrital garnet assemblages reflect the different metamorphic conditions in the geological source units. Pyrope-rich garnets increase within the Eclogite Zone consistent with the geological framework. The proportion of grossular is higher in the smaller grain-sizes, whereas the proportion of pyrope is higher in the coarser grain-size fractions, which probably results of the inheritance of grainsize from host rock to sediment. Due to the fact that grossular-rich garnet is less dense than other garnet species, a hydraulic effect is less likely than by the original finer grain-size distribution in the source rock, because less dense garnet-species are commonly found in the coarse tail of the grain-size distribution.

- Great care must be taken when outcrops of a rock type are only rarely present in the study area, because an influence of these rock types can be missed when only a few samples are available. This is the same case with minerals, which can be missed in a specific grain-size range and therefore lead to misleading results.

In summary, the amount of samples and a wide grain-size range are important features to consider when interpreting provenance data. They can provide a relatively clear and complete picture about the situation in the source area where external influences are small.

\section{Acknowledgments}

The PhD scholarship of AK is financed by CASP. Fieldwork and analytical work was financed by the German Research Foundation (DFG grant EY 23/20-1). We thank Andreas Kronz for his help with electron microprobe analyses, and Jasper Knight, Eduardo Garzanti and an anonymous reviewer for their constructive comments. 


\section{References}

Aitchison, J., 1986. The Statistical Analysis of Compositional Data, Monographs on Statisticsand Applied Probability. Chapman \& Hall Ltd., London, 416 pp.

Andò, S., 2007. Heavy minerals: provenance, hydraulic sorting, weathering. Unpublished PhD Thesis, University of Milano-Bicocca, $210 \mathrm{pp}$.

Andò, S., Morton, A., Garzanti, E., 2014. Metamorphic grade of source rocks revealed by chemical fingerprints of detrital amphibole and garnet. In: Scott, R.A., Smyth, H.R., Morton, A.C., Richardson, N. (Eds.), Sediment Provenance Studies in Hydrocarbon Exploration and Production. Geological Society of London, Special Publication 386, pp. 351-371.

Aubrecht, R., Méres, Š., Sýkora, M., Mikus, T., 2009. Provenance of the detrital garnets and spinels from the Albian sediments of the Czorsztyn Unit (Pieniny Klippen Belt, Western Carpathians, Slovakia). Geologica Carpathica 60, 463483.

Baxter, E.F., Caddick, M.J., Ague, J.J., 2013. Garnet: Common mineral, uncommonly useful. Elements 9, 415-419.

Cesare, B., Poletti, E., Boiron, M.C., Cathelineau, M., 2001. Alpine metamorphism and veining in the Zentralgneis Complex of the SW Tauern Window: a model of fluid-rock interactions based on fluid inclusions. Tectonophysics 336, 121-136.

Comas-Cufí, M., Thió-Henestrosa, S., 2011. CoDaPack 2.0: a stand-alone, multiplatform compositional software. In: Egozcue, J.J., Tolosana-Delgado, R., Ortego, M.I. (Eds.), CoDaWork'11: 4th International Workshop on Compositional Data Analysis. Sant Feliu de Guíxols, http://congress.cimne.com/codawork11/Admin/Files/FilePaper/p28.pdf.

Dachs, E., 1990. Geothermobarometry in metasediments of the southern Grossvenediger area (Tauern window, Austria). Journal of Metamorphic Geology 8, 217-230.

Dachs, E., Kurz, W., Proyer, A., 2005. Alpine eclogites in the Tauern window. Mitteilungen der Österreichischen Mineralogischen Gesellschaft 150, 199-226.

Deer, W.A., Howie, R.A., Zussman, J., 1992. An introduction to rock-forming minerals. Longman Group Ltd, Harlow, UK, 712 pp.

Dietrich, H., Koller, F., Richter, W., Kiesl, W., 1986. Petrologie und Geochemie des Rodingitvorkommens vom Islitzfall (Dorfertal, Hohe Tauern). Schweizerische Mineralogische und Petrographische Mitteilungen 66, 163-192. 
Frank, W., Höck, V., Miller, C., 1987. Metamorphic and tectonic history of the central Tauern window. In: Flügel, H.W., Faupl, P. (Eds.), Geodynamics of the Eastern Alps. Deuticke, Vienna, pp. 34-54.

Frank, W., Miller, C., Pestal, G., 1987. Geologische Karte der Republik Österreich 1:50000, sheet 152, Matrei in Osttirol. Geologische Bundesanstalt, Wien.

Garzanti, E., Andò, S., 2007. Heavy mineral concentration in modern sands: Implications for provenance interpretation. In: Mange, M.A., Wright, D.T. (Eds.), Heavy Mineral in Use. Developments in Sedimentology 58, pp. 517-545.

Garzanti, E., Doglioni, C., Vezzoli, G., Andò, S., 2007. Orogenic belts and orogenic sediment provenance. Journal of Geology 115, 315-334.

Garzanti, E., Andò, S., Vezzoli, G., 2008. Settling-equivalence of detrital minerals and grain-size dependence of sediment composition. Earth and Planetary Science Letters 273, 138-151.

Garzanti, E., Andò, S., Vezzoli, G., 2009. Grain-size dependence of sediment composition and environmental bias in provenance studies. Earth and Planetary Science Letters 277, 422-432.

Garzanti, E., Resentini, A., Vezzoli, G., 2010. Detrital fingerprints of fossil continentalsubduction zones (Axial Belt Provenance, European Alps). Journal of Geology 118, 341-362.

Hawkins, A.T., Selverstone, J., Brearley, A.J., Beane, R.J., Ketcham, R.A., Carlson, W.D., 2007. Origin and mechanical significance of honeycomb garnet in highpressure metasedimentary rocks from the Tauern Window, Eastern Alps. Journal of Metamorphic Geology 25, 565-583.

Holland, T., 1979. High water activities in the generation of high pressure kyanite eclogites of the Tauern window, Austria. Journal of Geology 87, 1-27.

Hoschek, G., 2007. Metamorphic peak conditions of eclogites in the Tauern Window, Eastern Alps, Austria: thermobarometry of the assemblage garnet+omphacite+phengite+quartz. Lithos 93, 1-16.

Hoschek, G., 2013. Garnet zonation in metapelitic schists from the Eclogite Zone, Tauern Window, Austria: comparison of observed and calculated profiles. European Journal of Mineralogy 25, 615-629.

Hubert, J.F., 1962. A zircon-tourmaline-rutile maturity index and the interdependence of the composition of heavy mineral assemblages with the gross composition and texture of sandstones. Journal of Sedimentary Research 32, 440-450. 
Inger, S., Cliff, R.A., 1994. Timing of metamorphism in the Tauern window, Eastern Alps: Rb-Sr-ages and fabric formation. Journal of Metamorphic Geology 12. 695-707.

Kurz, W., Neubauer, F., Dachs, E., 1998. Eclogite meso- and microfabrics: implications for the burial and exhumation history of eclogites in the Tauern window (Eastern Alps) from P-T-d path. Tectonophysics 285, 183-209.

Krippner, A., Meinhold, G., Morton, A.C., von Eynatten, H., 2014. Evaluation of garnet discrimination diagrams using geochemical data derived from various host rocks. Sedimentary Geology 306, 36-52.

Mange, M.A., Maurer, H.F.W., 1992. Heavy Minerals in colour, Chapman and Hall, London, 147 pp.

Mange, M.A., Morton, A.C., 2007. Geochemistry of heavy minerals. In: Mange, M.A., Wright, D.T. (Eds.), Heavy Minerals in Use. Developments in Sedimentology 58. Elsevier, Amsterdam, pp. 345-391.

Miller, C., 1977. Chemismus und phasenpetrologische Untersuchungen der Gesteine aus der Eklogitzone des Tauernfensters. Tschermaks mineralogische und petrographische Mitteilungen 24, 221-277.

Miller, C.F., Stoddard, E.F., 1981. The role of manganese in the paragenesis of magmatic garnet: an example from the Old Woman-Piute Range, California. Journal of Geology 89, 233-246.

Miller, C., Konzett, J., Tiepolo, M., Armstrong, R.A., Thöni, M., 2007. Jadeite-gneiss from the Eclogite Zone, Tauern window, Eastern Alps, Austria: Metamorphic, geochemical and zircon record of a sedimentary protolith. Lithos 93, 68-88.

Morton, A.C., 1985. A new approach to provenance studies: electron microprobe analysis of detrital garnets from Middle Jurassic sandstones of the northern North Sea. Sedimentology 32, 553-566.

Morton, A.C., 1987. Influences of provenance and diagenesis on detrital garnet suites in the Forties sandstone, Paleocene, central North Sea. Journal of Sedimentary Petrology 57, 1027-1032.

Morton, A.C., 1991. Geochemical studies of detrital heavy minerals and their application to provenance research. In: Morton, A.C., Todd, S.P., Haughton, P.D.W. (Eds.), Developments in Sedimentary Provenance Studies. Geological Society of London, Special Publications 57, pp. 31-45. 
Morton, A.C., 2012. Value of heavy minerals in sediments and sedimentary rocks for provenance, transport history and stratigraphic correlation. In: Sylvester, P. (Ed.), Quantitative Mineralogy and Microanalysis of Sediments and Sedimentary Rocks. Mineralogical Association of Canada Short Course Series 42, pp. 133165.

Morton, A.C., Hallsworth, C.R., 1999. Processes controlling the composition of heavy mineral assemblages in sandstones. Sedimentary Geology 124, 3-29.

Morton, A.C., Hallsworth, C.R., 2007. Stability of detrital heavy minerals during burial diagenesis. In: Mange, M., Wright, D.T. (Eds.), Heavy Minerals In Use. Developments in Sedimentology, 58, pp. 215-245.

Morton, A., Hallsworth, C., Chalton, B., 2004. Garnet compositions in Scottish and Norwegian basement terrains: a framework for interpretation of North Sea sandstone provenance. Marine and Petroleum Geology 21, 393-410.

Neufeld, K., Ring, U., Heidelbach, F., Dietrich, S., Neuser, R.D., 2008. Omphacite textures in eclogites of the Tauern window: Implications for the exhumation of the Eclogite Zone, Eastern Alps. Journal of Structural Geology 30, 976-992.

Patranabis-Deb, S., Schieber, J., Basu, A., 2008. Almandine garnet phenocrysts in a $\sim 1 \mathrm{Ga}$ rhyolitic tuff from central India. Geological Magazine 146, 133-143.

Pfiffner, O.A., 2014. Geology of the Alps. 2nd Edition, John Wiley \& Sons Inc, New York, $386 \mathrm{pp}$.

Schuiling, R.D., de Meijer, R.J., Riezebos, H.J., Scholten, M.J., 1985. Grain-size distribution of different minerals in a sediment as a function of their specific density. Geologie en Mijnbouw 64, 199-203.

Selverstone, J., 1993. Micro- to macroscale interactions between deformational and metamorphic processes, Tauern window, Eastern Alps. Schweizerische Mineralogische und Petrographische Mitteilungen 73, 229-239.

Stöckhert, B., Massone, H.J., Nowlan, E.U., 1997. Low differential stress during highpressure metamorphism. The microstructural record of a metapelite from the Eclogite Zone, Tauern window, Eastern Alps. Lithos 41, 103-118.

Suggate, S.M., Hall, R., 2014. Using detrital garnet compositions to determine provenance: a newcompositional database and procedure. In: Scott, R.A., Smyth, H.R.,Morton, A.C., Richardson, N. (Eds.), Sediment Provenance Studies in Hydrocarbon Exploration and Production. Geological Society of London, Special Publication 386, pp. 373-393. 
van Andel, Tj.H., 1950. Provenance, transport and deposition of Rhine sediments: a heavy mineral study on river sands from the drainage area of the Rhine. Dissertation, Rijksuniversiteit te Groningen, Veenman \& Zonen, Wageningen, $129 \mathrm{pp}$.

von Eynatten, H., Barceló-Vidal, C., Pawlowsky-Glahn, V., 2003. Modelling compositional change: the example of chemical weathering of granitoid rocks. Mathematical Geology 35, 231-251.

von Quadt, A., Günther, D., Frischknecht, R., 1997. The evolution of pre-Variscan eclogites of the Tauern Window (Eastern Alps): A Sm/Nd-, conventional and Laser ICP-MS zircon U-Pb study. Schweizerische Mineralogische und Petrographische Mitteilungen 77, 265-279.

Wright, W.I., 1938. The composition and occurrence of garnets. American Mineralogist 23, 436-449.

Velbel, M.A., 2007. Surface textures and dissolution processes of heavy minerals in thesedimentary cycle: examples from pyroxenes and amphiboles. In: Mange, M., Wright, D.K. (Eds.), Heavy Minerals In Use. Developments in Sedimentology 58, Elsevier, Amsterdam, pp. 112-150.

Zimmermann, R., Franz, G., 1989. Die Eklogite der Unteren Schieferhülle; Frosnitztal/Großvenediger (Tauern, Österreich). Mitteilungen der Österreichischen Geologischen Gesellschaft 81, 167-188.

Zimmermann, R., Hammerschmidt, K., Franz, G., 1994. Eocene high pressure metamorphism in the Penninic units of the Tauern Window (Eastern Alps): evidence from ${ }^{40} \mathrm{Ar}-{ }^{39} \mathrm{Ar}$ dating and petrological invistigastions. Contribution of Mineralogy and Petrology 117, 175-186. 


\title{
Manuscript III: Heavy minerals and garnet geochemistry of stream sediments and hardrocks from the Almklovdalen area, Western Gneiss Region, SW Norway: implications for provenance analysis
}

\author{
Anne Krippner ${ }^{1,{ }^{*}}$, Guido Meinhold ${ }^{1}$, Andrew C. Morton ${ }^{2,3}$, Jan Schönig ${ }^{1}$, Hilmar von \\ Eynatten ${ }^{1}$
}

${ }^{1}$ Department of Sedimentology and Environmental Geology, University of Göttingen, Goldschmidtstraße 3, 37077 Göttingen, Germany

${ }^{2}$ CASP, West Building, 181A Huntingdon Road, Cambridge CB3 0DH, United Kingdom

${ }^{3} \mathrm{HM}$ Research Associates, 2 Clive Road, Balsall Common, West Midlands CV7 7DW, United Kingdom

Sedimentary Geology (Special Issue: WGSG2015) (in press).

\begin{abstract}
Detrital heavy minerals commonly document the geological setting in the source area, hence they are widely used in sedimentary provenance analysis. In heavy mineral studies, the 63-125 and 63-250 $\mu \mathrm{m}$ grain size fractions are most commonly used. Heavy mineral data and garnet geochemistry of stream sediments and bedrocks from the catchment area draining the Almklovdalen peridotite massif in SW Norway reveal that a wider grain size spectrum needs to be considered to avoid misleading interpretations. The Almklovdalen peridotite massif consists mainly of dunite and harzburgite, as testified by the heavy mineral suite. At the outlet of the main river, the heavy mineral spectrum is very monotonous due to dilution by a strong influx of olivine. Heavy minerals like apatite and epidote characterising the host gneisses have almost disappeared. MgO-rich almandine garnets are more frequent in the coarser grain size fractions, whereas $\mathrm{MnO}$-rich almandine garnets are more frequent in the finer grain size fractions. Garnets with pyrope content exceeding
\end{abstract}


$50 \%$ are only found in the $500-1000 \mu \mathrm{m}$ grain size fraction. Therefore, the sample location and the selected grain size fraction are of paramount importance when dealing with heavy minerals and mineral geochemical data; otherwise, provenancesensitive information may be missed.

Keywords: heavy minerals; garnet geochemistry; compositional biplot; provenance; Almklovdalen peridotite massif

\section{Introduction}

Heavy minerals are used to characterise, discriminate, and identify source areas (Mange and Wright, 2007; von Eynatten and Dunkl, 2012, and references therein). Commonly, the heavy mineral composition of a sediment reflects the mineralogy of the rocks exposed in the source area; however, the heavy mineral assemblage may be affected by several processes during the sedimentary cycle that modify the occurrence and proportions of heavy mineral species (e.g., Morton and Hallsworth, 1999). For instance, the stability of heavy minerals strongly depends on the specific environment and climatic conditions (Pettijohn, 1941; Morton and Hallsworth, 1999; Velbel, 2007; Andò et al., 2012; Morton, 2012; Garzanti et al., 2013). Therefore, differences in heavy mineral ratios are not necessarily the effect of different sources, but can reflect modifications which occur during the sedimentary cycle (e.g., Morton and Hallsworth, 1999). When studying stream sediments, it must be noted that minerals can be segregated and sorted according to their grain size, density, and shape (Morton and Hallsworth, 1999; Garzanti et al., 2008, 2009; Resentini et al., 2013). This can happen either between different heavy mineral species, but also within a single mineral group. For example, almandine-rich garnets are commonly concentrated in the finer fractions in contrast to less dense garnet species (Schuiling et al., 1985; Andò, 2007; Garzanti et al., 2008).

The heavy mineral garnet has important provenance applications because it exists in a wide range of rocks and its chemical composition depends on the composition of the source rock and on pressure and temperature conditions during garnet formation (e.g., Wright, 1938; Morton, 1985; Deer et al., 1992; Andò et al., 2013; Krippner et al., 2014). Although garnets from various garnet-bearing rocks often show much overlap in major element geochemistry, mantle-derived garnets, for instance, can be very well separated from crustal-derived garnets (e.g., Krippner et al., 2014). 
Therefore, garnet is used as an indicator mineral in exploration, for instance, for diamonds (Nowicki et al., 2003) because mantle-derived garnets can be related to diamond-bearing intrusives (Grütter et al., 2004). In contrast to the typical mantlederived minerals olivine and pyroxene, garnet is more stable during alteration and dispersion at the Earth's surface (e.g., Pettijohn, 1941; Gurney, 1984; Velbel, 1984, 1999; Grütter et al., 2004; Morton, 2012).

We collected stream sediments and adjacent source rocks in the high-grade metamorphic Almklovdalen area in SW Norway to study to what extent the heavy mineral suites and garnet composition of the stream sediments reflect the mineralogy of the source rocks. We analysed different grain size fractions in order to test for grain size dependency of heavy mineral assemblages and garnet geochemistry, which may lead to ambiguous or even wrong interpretations when a single and narrow grain size spectrum is considered only (Garzanti et al., 2009).

\section{Geological Setting}

The Almklovdalen area is located in the Western Gneiss Region (WGR) in SW Norway (Fig. 1). The WGR comprises Precambrian basement and allochthonous cover units, metamorphosed and deformed during the Caledonian orogeny induced through collisions between Baltica, Laurentia and Avalonia under closure of the lapetus Ocean (Roberts and Gee, 1985; Cuthbert et al., 2000; Krabbendam et al., 2000; Beyer et al., 2012). The gneisses and augen orthogneisses of the WGR are mainly of granodioritic to granitic composition and are considered to represent Baltica basement (Tucker et al., 1990). The gneisses are predominantly of amphibolite facies metamorphic grade (Bryhni and Andréasson, 1985; Krabbendam and Wain, 1997; Krabbendam et al., 2000), but in some parts, granulite facies assemblages occur (Griffin et al., 1985; Krabbendam et al., 2000). Most of the orthogneisses of the WGR are suggested to be generated during Gothian (1.7-1.5 Ga) and Sveconorwegian (1.2-1.9 Ga) events (Beyer et al., 2012). During the Scandian phase (435-390 Ma) of the Caledonian orogeny, rocks of the WGR suffered highpressure (HP) to ultrahigh-pressure (UHP) conditions (Griffin and Brueckner, 1980; Gebauer et al., 1985; Griffin et al., 1985; Mørk and Mearns, 1985; Andersen et al., 1991; Krabbendam et al., 2000). The metamorphic grade increases from SE to NW (Krogh, 1977; Cuthbert et al., 2000; Root et al., 2005; Beyer et al., 2012). The temperature gradient increases from $\sim 550{ }^{\circ} \mathrm{C}$ in the $\mathrm{SE}$ to $>800^{\circ} \mathrm{C}$ in the $\mathrm{NW}$ 
(Krogh, 1977; Griffin et al., 1985; Carswell and Cuthbert, 2003). Mafic and ultramafic lenses which are enclosed within the surrounding gneisses range in size from centimetres to hundreds of metres (Carswell and Cuthbert, 2003). A few ultramafic bodies reach sizes up to several kilometres. There are hundreds of mantle-derived ultramafic bodies (Beyer et al., 2012), with some of them containing garnet-bearing assemblages (Eskola, 1921; Medaris, 1984; Carswell, 1986; Medaris and Carswell, 1990; Brueckner et al., 2010; Beyer et al., 2012). The ultramafic rocks show Archaean Re-Os ages, which predate the formation of the Proterozoic upper crusts in the region (Brueckner et al., 2002; Beyer et al., 2004). One of the largest ultramafic bodies, with a size of $4.0 \times 3.3 \mathrm{~km} 2$, is the Almklovdalen peridotite (Medaris and Brueckner, 2003), located in the HP-UHP transition zone (Fig. 1). This ultramafic body is a bowl-shaped sheet around a central gneiss area, composed of orthogneisses and paragneisses and indicates three main stages of deformation. The first deformation is seen in the Proterozoic folds in the garnet peridotite, a second deformation is highlighted by the Caledonian isoclinal folds in the chlorite peridotite in association with recrystallisation of garnet peridotite to chlorite peridotite, and a third deformation-also Caledonian in age-led to foliations and lineations in chlorite peridotite (Medaris and Brueckner, 2003). The main rock types in the Almklovdalen body are anhydrous dunite and harzburgite (Osland, 1997; Medaris and Brueckner, 2003; Beyer et al., 2006, 2012). They contain garnet peridotite and garnet pyroxenite lenses (Medaris, 1984; Osland, 1997; Beyer et al., 2012), which occur in $<40-\mathrm{cm}$ thick bands within the dunites and harzburgites (Cordellier et al., 1981). Eclogites are also present, but only in minor amounts (Griffin and Qvale, 1985; Beyer et al., 2012). The Almklovdalen body is surrounded by orthogneisses, paragneisses, anorthosites, and eclogites (Beyer et al., 2012). 


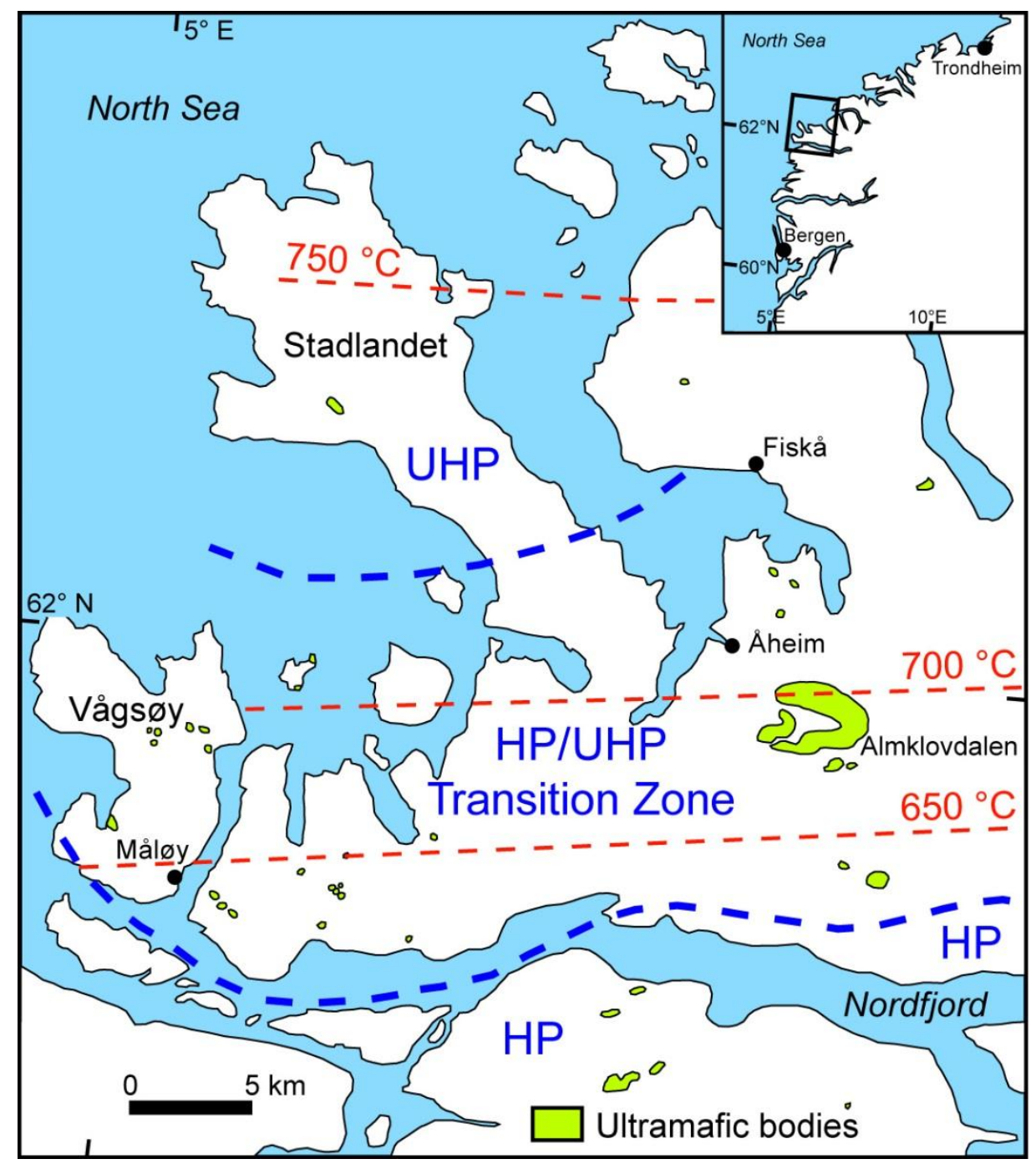

Fig.1. Map of the outer Nordfjord and Stradlandet area of the Western Gneiss Region showing the distribution of ultramafic bodies. Dashed lines mark the limits of the HP and UHP zones and the extent of the mixed HP/UHP zone (adapted from Carswell and Cuthbert, 2003). The inset shows the location of the study area in the SW part of the Caledonides in Norway.

\section{Samples and methods}

\subsection{Samples}

Four sand samples were collected from streams draining the Almklovdalen peridotite body (Fig. 2). Loose bedload sand was sampled to cover a wide grain size range. Stream sample AK-N20 was collected $\sim 1 \mathrm{~km}$ SE of Helgehornet, followed by sample AK-N19-4 further downstream (Fig. 2). Stream sample AK-N19-3 was taken from the middle part of the Gusdalselva river and stream sample AK-N19-1 comes from the mouth of the Gusdalselva river entering lake Gusdalsvatnet. In addition, bedrock samples were collected since they represent the source for the detrital material. 
Bedrock samples were taken in outcrops. One bedrock sample, a large pebble, was taken directly from the river bed. Sample AK-N21 is an eclogite exposed south of Helgehornet and AK-EA is an eclogite pebble collected at the mouth of the Gusdalselva river. Sample AK-N24 is a garnet peridotite and AK-N25 is a gneiss exposed SE of Helgehornet. The geographic coordinates of all samples are given in Table 1.

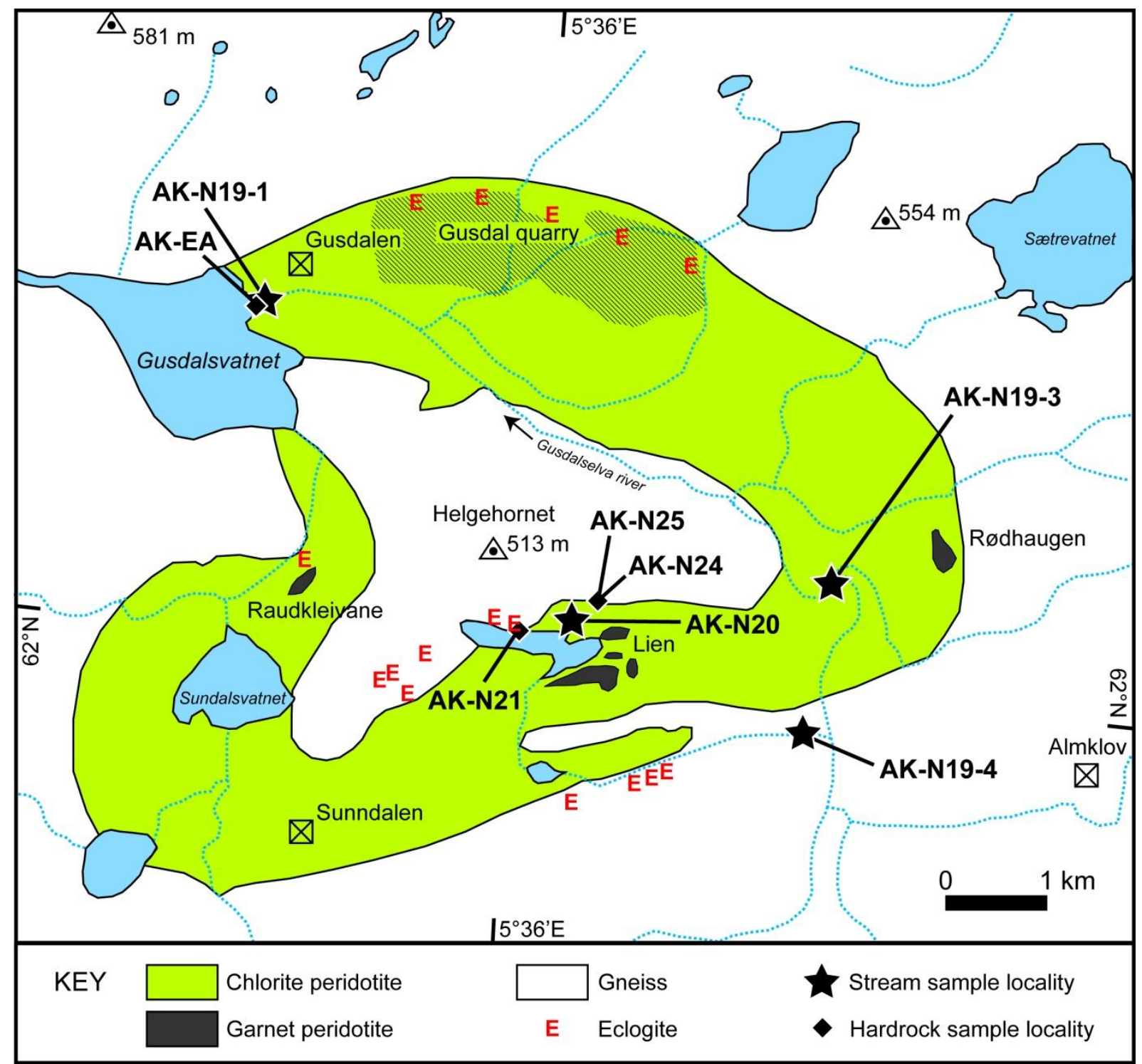

Fig. 2. Geological map of the Almklovdalen area (adapted from Medaris and Brueckner, 2003) showing sample locations. The eclogite occurrences have sizes up to several metres and are enclosed within both the gneisses and peridotites. 
Table 1. Geographic coordinates (WGS 84) of all samples (river sediments and bedrocks) from the Almklovdalen area.

\begin{tabular}{|l|l|l|l|}
\hline sample & bedrock/sediment & GPS: $\mathbf{N}^{\circ}$ & GPS: $^{\circ}$ \\
\hline AK-N20 & sediment & $62^{\circ} 00.202^{\prime}$ & $5^{\circ} 36.268^{\prime}$ \\
\hline AK-N19-4 & sediment & $62^{\circ} 00.001^{\prime}$ & $5^{\circ} 37.573^{\prime}$ \\
\hline AK-N19-3 & sediment & $62^{\circ} 00.315^{\prime}$ & $5^{\circ} 37.690^{\prime}$ \\
\hline AK-N19-1 & sediment & $62^{\circ} 01.010^{\prime}$ & $5^{\circ} 34.417^{\prime}$ \\
\hline AK-N21 & eclogite & $62^{\circ} 00.153^{\prime}$ & $5^{\circ} 35.998^{\prime}$ \\
\hline AK-EA & eclogite & $62^{\circ} 01.010^{\prime}$ & $5^{\circ} 34.417^{\prime}$ \\
\hline AK-N24 & Garnet peridotite & $62^{\circ} 00.278^{\prime}$ & $5^{\circ} 36.448^{\prime}$ \\
\hline AK-N25 & gneiss & $62^{\circ} 00.278^{\prime}$ & $5^{\circ} 36.448^{\prime}$ \\
\hline
\end{tabular}

\subsection{Methods}

Stream sediments were wet-sieved using a mechanical shaker to separate the different grain size fractions (63-125 $\mu \mathrm{m}, 125-250 \mu \mathrm{m}, 250-500 \mu \mathrm{m}, 500-1000 \mu \mathrm{m})$. We used $\sim 350 \mathrm{~g}$ per sample. After drying, the samples were treated with acetic acid to remove the carbonate component if present. The heavy mineral fractions were separated using sodium polytungstate (SPT) with a density of $2.85 \mathrm{~g} / \mathrm{mL}$.

The heavy mineral residues were mounted on microscope slides (Mange and Maurer, 1992) using Meltmount ${ }^{\mathrm{TM}}$ with a refraction of 1.66 and identified under the polarising microscope. The relative abundances of the heavy minerals were determined by grain counting. For that, the microscope slide was moved along linear traverses and all grains between two parallel lines were counted (i.e. ribbon counting; Mange and Maurer, 1992). Two-hundred and fifty translucent minerals were counted for each slide. All data are given as supplementary data, i.e. data of all heavy minerals including opaque minerals, micas and unknown (Supplementary Table S1), only groups of transparent minerals (see Supplementary Table S2), and heavy minerals from all grain size fractions (Supplementary Table S3).

Unknown minerals probably originate from alterations of various minerals and are aggregates with no well-defined mineralogical composition. They are also termed as alterites (van Andel, 1950).

For garnet geochemical analysis, garnet selection from the stream sediments was achieved by handpicking under a binocular microscope. We randomly selected garnet grains of all sizes and morphological types and placed them in synthetic mounts using a bonding epoxy composed of a mixture of Araldite ${ }^{\circledR}$ resin and 
hardener at a ratio of 5:1. Grains of different morphological types were selected to consider a wide range of altered and non-altered garnets in the source area. Also, garnets of different colours in approximately similar amounts were selected to minimize the bias of picking only one type of garnet.

From the bedrock samples, polished thin sections were prepared. Garnet from bedrock and stream samples were analysed with a JEOL JXA 8900 RL electron microprobe (EMP) equipped with five wavelength dispersive spectrometers at the University of Göttingen (Department of Geochemistry, Geoscience Center). Before analysis, all samples were coated with carbon to ensure conductivity. Conditions included an accelerating voltage of $15 \mathrm{kV}$ and a beam current of $20 \mathrm{nA}$. The counting times were $15 \mathrm{~s}$ for $\mathrm{Si}, \mathrm{Mg}, \mathrm{Ca}, \mathrm{Fe}$ and $\mathrm{Al}$, and $30 \mathrm{~s}$ for $\mathrm{Ti}, \mathrm{Cr}$ and $\mathrm{Mn}$ (Table 2). Matrix correction was performed using ZAF corrections. We preferentially analysed garnet rims and cores. From the thin sections, 20 garnets from each sample were analysed and 50 garnets of each sediment sample were measured. Additionally, minerals in thin sections were determined under the polarising microscope. The relative abundances of the main light and heavy minerals from the bedrocks can be taken from Table 3. The full database including lithology and metamorphic grade are included in Supplementary Table S4.

Table 2. Operating conditions of the electron microprobe for garnet analyses. Count time on the peak (in s), Bckg time counting time on background position (in s), $D L$ detection limit (in ppm).

\begin{tabular}{|c|c|c|c|c|c|c|c|c|}
\hline Spectrometer & $1 \mathrm{TAP}$ & $1 \mathrm{TAP}$ & 2 TAP & 3 PETJ & 4 PETJ & 4 PETJ & 5 LIFH & 5 LIFH \\
\hline $\begin{array}{l}\text { Element } \\
\text { (Line) }\end{array}$ & $\mathrm{Si}(\mathrm{K} \alpha)$ & $\mathrm{Al}(\mathrm{K} \alpha)$ & $\mathrm{Mg}(\mathrm{K} \alpha)$ & $\mathrm{Ca}(\mathrm{Ka})$ & $\mathrm{Ti}(\mathrm{K} \alpha)$ & $\mathrm{Cr}(\mathrm{K} \alpha)$ & $\mathrm{Mn}(\mathrm{K} \alpha)$ & $\mathrm{Fe}(\mathrm{K \alpha})$ \\
\hline Count time & 15 & 15 & 15 & 15 & 30 & 30 & 30 & 15 \\
\hline $\begin{array}{l}\text { Bckg time } \\
\text { Standard }\end{array}$ & $\begin{array}{l}5 \\
\text { Garnet, } \\
\text { natural }\end{array}$ & $\begin{array}{l}5 \\
\text { Garnet, } \\
\text { natural }\end{array}$ & $\begin{array}{l}5 \\
\mathrm{MgO}, \\
\text { synthetic }\end{array}$ & $\begin{array}{l}5 \\
\mathrm{CaSiO}_{3} \\
\text { natural }\end{array}$ & $\begin{array}{l}15 \\
\mathrm{TiO}_{2} \text {, } \\
\text { synthetic }\end{array}$ & $\begin{array}{l}15 \\
\mathrm{Cr}_{2} \mathrm{O}_{3} \\
\text { synthetic }\end{array}$ & $\begin{array}{l}15 \\
\text { Rhodonite, } \\
\text { natural }\end{array}$ & $\begin{array}{l}5 \\
\mathrm{Fe}_{2} \mathrm{O}_{3} \\
\text { synthetic }\end{array}$ \\
\hline $\mathrm{DL}$ & 160 & 138 & 104 & 138 & 113 & 135 & 117 & 216 \\
\hline
\end{tabular}

From all stream sediment samples, the 63-125 $\mu \mathrm{m}$ fractions were point-counted and analysed by EMP. For the study of grain size dependency, sample AK-N19-3 was chosen. From this sample, the $125-250 \mu \mathrm{m}$ and $250-500 \mu \mathrm{m}$ grain size fractions were also point-counted, and garnet grains from the 125-250 $\mu \mathrm{m}, 250-500 \mu \mathrm{m}$ and 500-1000 $\mu \mathrm{m}$ size fractions were analysed by EMP.

We measured the long and short axes of $\sim 100$ garnet grains from the $63-125 \mu \mathrm{m}$ grain size fraction of each river sample, to study if the garnets are mainly separated 
by their short axis or mainly by their long axis and if there is an appreciable input of garnets with smaller or coarser grain size, which do not belong to the specific grain size fraction. Long and short axes of garnet from bedrocks (AK-N21, AK-EA, AKN24) were also measured for comparison (Supplementary Table S5).

The geochemical data are presented in ternary diagrams following Mange and Morton (2007) and in biplots produced using CoDaPack, an open source software for compositional data analysis (Thió-Henestrosa and Martín-Fernández, 2005; ComasCufí and Thió-Henestrosa, 2011). The biplots are based on principal component analysis (PCA) using centred log-ratio transformation for six major element oxides, following the methodology proposed by Aitchison (1986). The biplots serve as a valuable tool for estimating the potential for discrimination of a multivariate data set and its subsets (e.g., von Eynatten et al., 2003). In biplots, multivariate observations are illustrated as points and variables as lines. The length of the line corresponds to the variability of the respective element. The length and position of the line reflects its relative influence on the respective principal component.

\section{Results}

\subsection{Heavy mineral analysis of all stream samples (63-125 $\mu \mathrm{m})$}

In all stream samples, olivine is the dominant heavy mineral representing between $39 \%$ and $90 \%$ of the heavy mineral suite (Fig. 3a). Pyroxene comprises between $8 \%$ and $11 \%$ (mainly diopsitic to augitic clinopyroxenes). Garnet, green calcic amphibole, epidote-group minerals (epidote, zoisite), and apatite occur in different percentages. The amphiboles are dominantly blue-green with colour changing from blue-green to green. Ultrastable minerals (zircon, tourmaline and rutile) are not present or occur only in traces. Other amphiboles (mainly actinolites and tremolites) and titanites occur occasionally as single grains in individual samples and are grouped as 'others'. Opaque minerals and micas are not considered in the diagram to emphasize the relative concentrations of the transparent heavy minerals.

\subsection{Heavy mineral analysis of sample AK-N19-3 (63-125 $\mu \mathrm{m}, 125-250 \mu \mathrm{m}$, 250-500 $\mu \mathrm{m}$ )}

Olivine is the dominant heavy mineral with similar amounts $(59 \%-63 \%)$ in all grain size fractions (Fig. 3b). Garnet content is higher in the coarser grain size fractions, 
i.e. $28 \%$ in the $125-250 \mu \mathrm{m}$ fraction and $24 \%$ in the $250-500 \mu \mathrm{m}$ fraction compared to $9 \%$ in the $63-125 \mu \mathrm{m}$ fraction. In contrast, pyroxene and green calcic amphibole decrease in the coarser fractions. The content of epidote group minerals remains fairly constant, whereas apatite (5\%) is only found in the $63-125 \mu \mathrm{m}$ grain size fraction. Ultrastable minerals are almost absent in the 250-500 $\mu \mathrm{m}$ fraction. The 500-1000 $\mu \mathrm{m}$ grain size fraction is not considered here because of the very high proportion of micas and opaque minerals, which amounts to almost $90 \%$ of the entire heavy mineral spectrum. 
a)

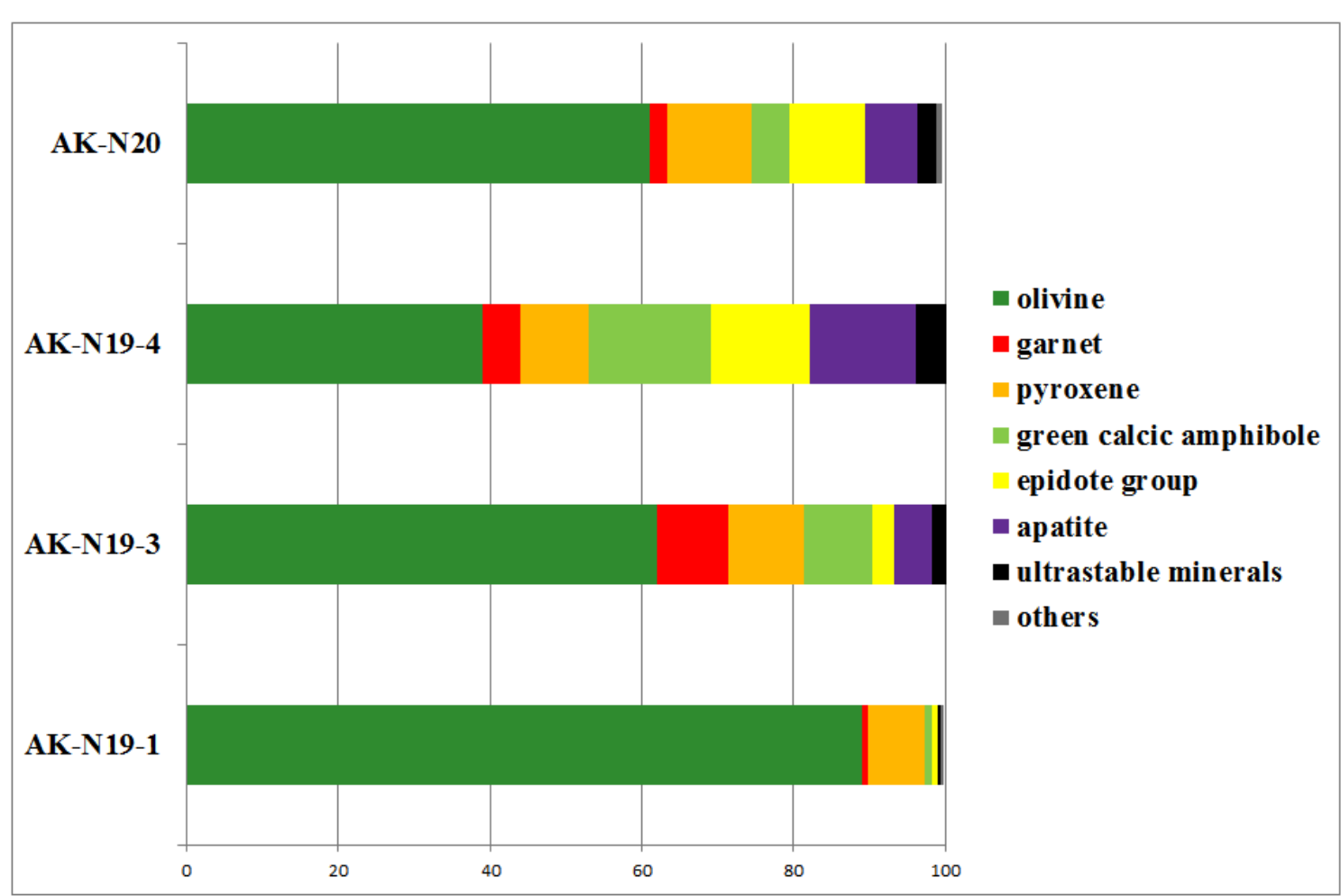

b)

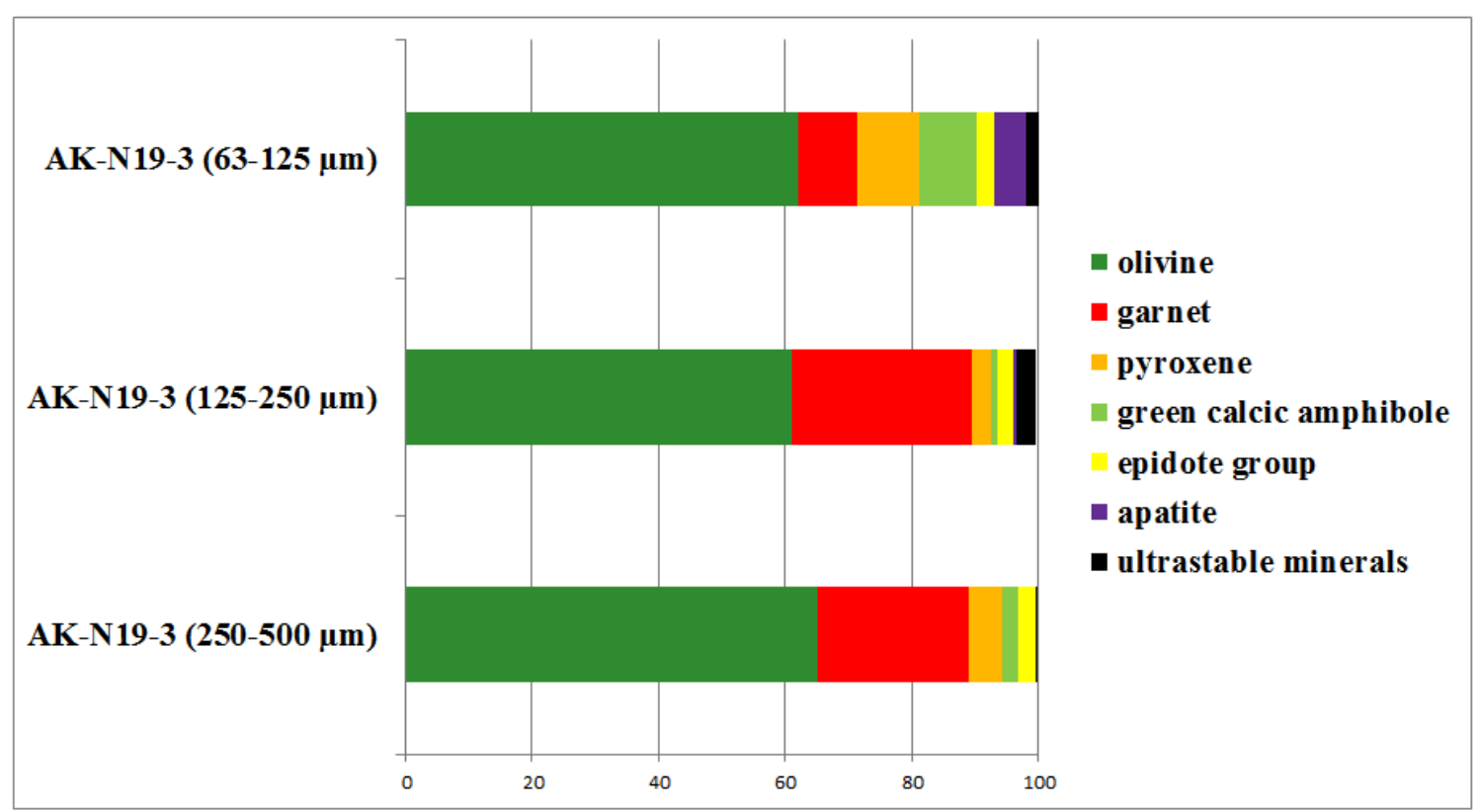

Fig. 3 (a) Transparent heavy mineral suite of the $63-125 \mu \mathrm{m}$ grain size fraction of the analysed samples. (b) Heavy mineral distribution of all grain size fractions of samples AK-N19-3. Epidote group: epidote, zoisite; ultrastable minerals: zircon, rutile, tourmaline; others: titanite, other amphibole (excluding green calcic amphibole).

\subsection{Grain-sizes of garnets}

The shortest axes of garnets from the $63-125 \mu \mathrm{m}$ sieve fractions of the stream sediments range from $>40-180 \mu \mathrm{m}$ and the longest axes range from $>80$ to $300 \mu \mathrm{m}$ (Fig. 4; Supplementary Table S5). The shortest axes of garnets from the eclogite 
bedrocks are between $<100$ and $700 \mu \mathrm{m}$ and the longest axes between $100 \mu \mathrm{m}$ and $>1000 \mu \mathrm{m}$ (Fig. 4; Supplementary Table 5).

The garnets of sample AK-N24 (garnet peridotite) are very coarse and go beyond the camera's field of view of the microscope. The shortest axis of the smallest grain found in this sample is $1000 \mu \mathrm{m}$ and the longest axis of the largest grain is about $1.4 \mathrm{~cm}$ (measured with a ruler). 
Stream Sediments
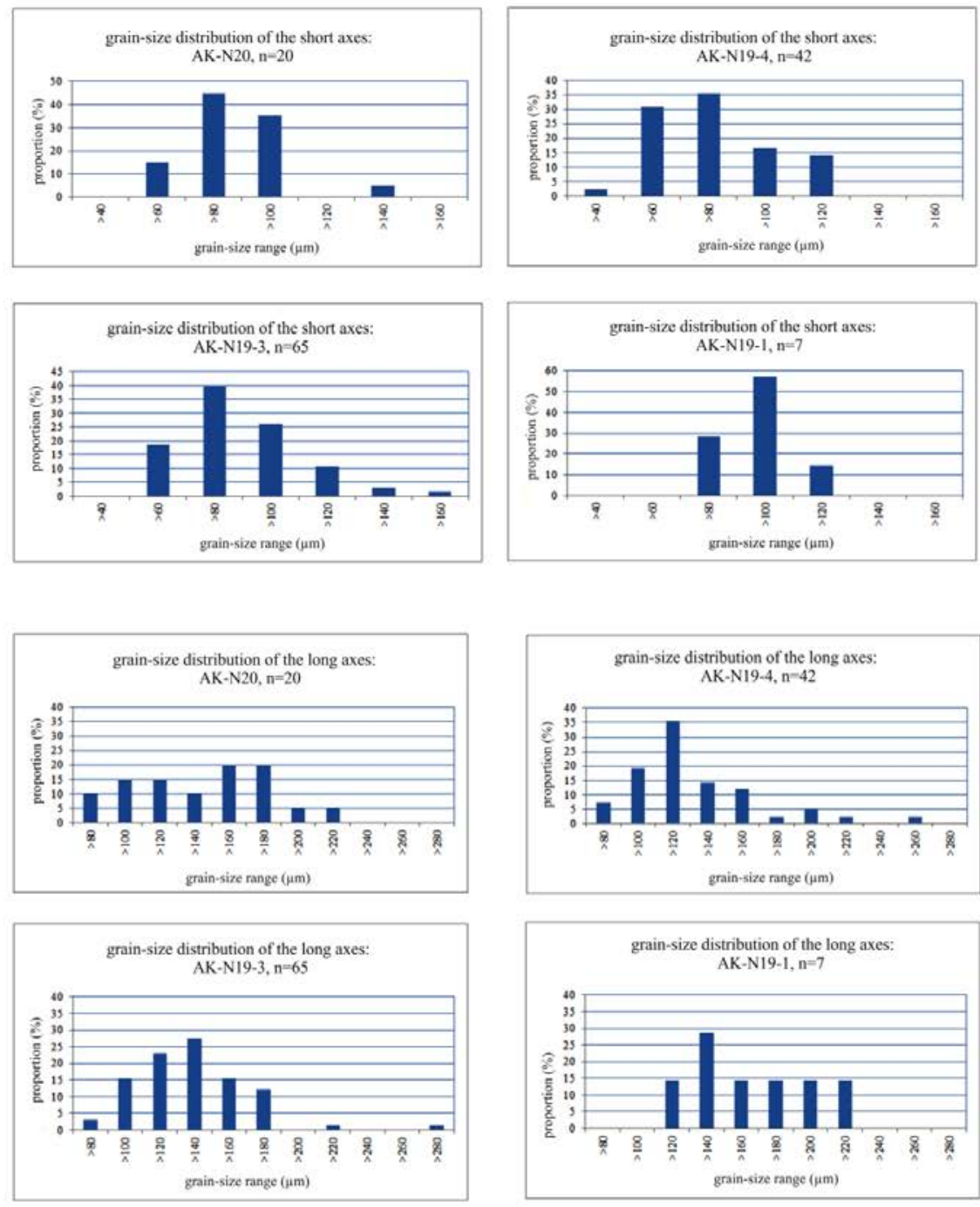

Bedrocks
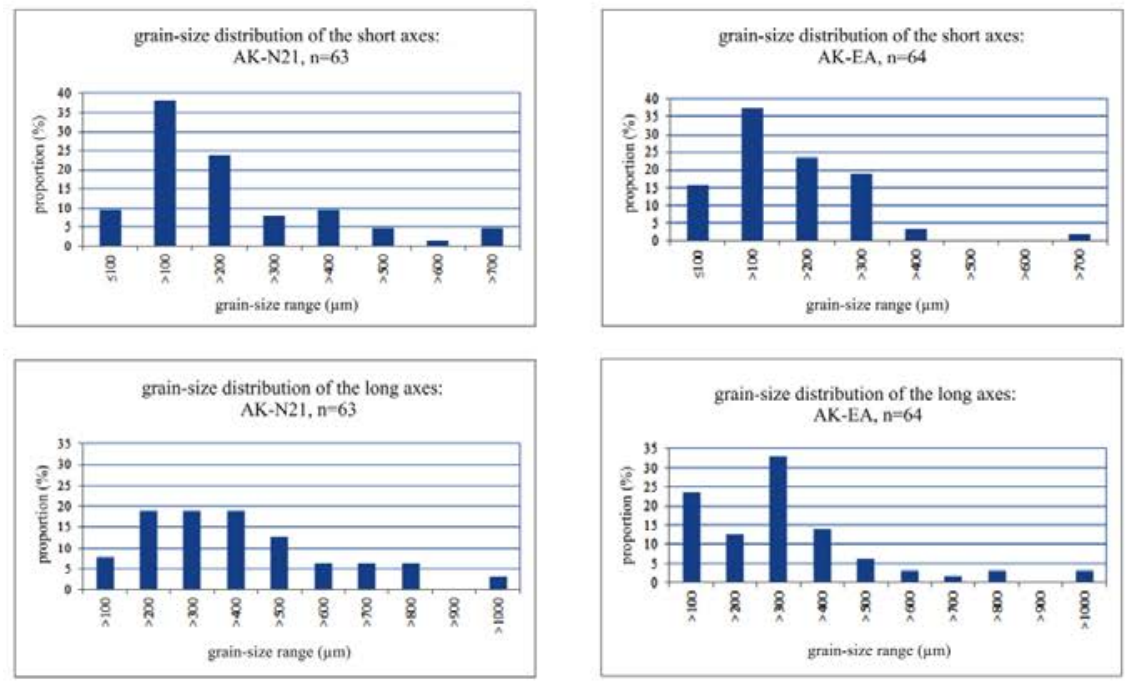

Fig. 4. Grain-size distribution of the short and the long axes of garnets from stream sediments of the 63-125 $\mu \mathrm{m}$ grain-size fraction (upper part) and of the eclogite samples AK-N21 and AK-EA (lower part). 


\subsection{Geochemistry of garnets}

Biplots with the major element oxides $\mathrm{SiO} 2, \mathrm{Al} 2 \mathrm{O} 3, \mathrm{CaO}, \mathrm{MgO}, \mathrm{FeO}$ and $\mathrm{MnO}$ as variables are used to differentiate garnets from the different bedrock types and from the sediments (Fig. 5). These diagrams are optimal in the sense that most of the total variability is illustrated in two dimensions (i.e. $89 \%-99 \%$ in this case). $\mathrm{SiO} 2$ and Al2O3 show the lowest variation in all of the three biplots (Fig. 5a, b, c). The small distance between $\mathrm{SiO} 2$ and $\mathrm{Al} 2 \mathrm{O} 3$ indicates relatively constant $\mathrm{SiO} 2 / \mathrm{Al} 2 \mathrm{O} 3$ ratios typical for all garnet varieties with aluminum in the crystallographic Y-site (i.e. endmembers almandine, spessartine, pyrope, grossular).

The major element data of the garnets from the bedrocks show the highest variability for $\mathrm{MnO}$ and $\mathrm{MgO}$ (spread in opposite directions and strongly controlling PC1) and a moderate variability for $\mathrm{CaO}$ and $\mathrm{FeO}$ along with fairly constant $\mathrm{CaO} / \mathrm{FeO}$ (Fig. 5a). The three bedrock samples are clearly separated from each other in the biplot, with garnets from the peridotite being distinct due to relative high $\mathrm{MgO}$ content. Garnets of the eclogites accumulate on the left side of the biplot indicating relatively lower $\mathrm{MgO}$ content, with garnets of sample AK-N21 appearing to have slightly higher relative $\mathrm{MnO}$ content (i.e. higher $\mathrm{MnO} / \mathrm{CaO}$ ratios), when compared to eclogite sample AKEA (Fig. 5a).

The detrital garnets show a comparably high variability for $\mathrm{MnO}, \mathrm{MgO}$ and $\mathrm{CaO}$ (spread in different directions) and show much overlap between both different samples and different grain size fractions (Fig. $5 \mathrm{~b}, \mathrm{c}$ ). The $\mathrm{CaO} / \mathrm{FeO}$ value is no longer constant, particularly for the coarser grain size fraction (Fig. $5 \mathrm{c}$ ). $\mathrm{CaO}$ and $\mathrm{MnO}$ have the highest impact on PC2, which in turn has much higher impact on the total variability of the detrital garnets $(22 \%$ and $26 \%)$ compared to the bedrocks $(7 \%$; Fig. 5). This implies higher relevance of $\mathrm{CaO} / \mathrm{MnO}$ ratios for the variability of the detrital garnets. The detrital garnets of the different grain size fractions of sample AKN19-3 show only little contrast. However, few garnets of the coarser grain size fractions (250-1000 $\mu \mathrm{m})$ show overlap with the garnet peridotite (Fig. 5c). 


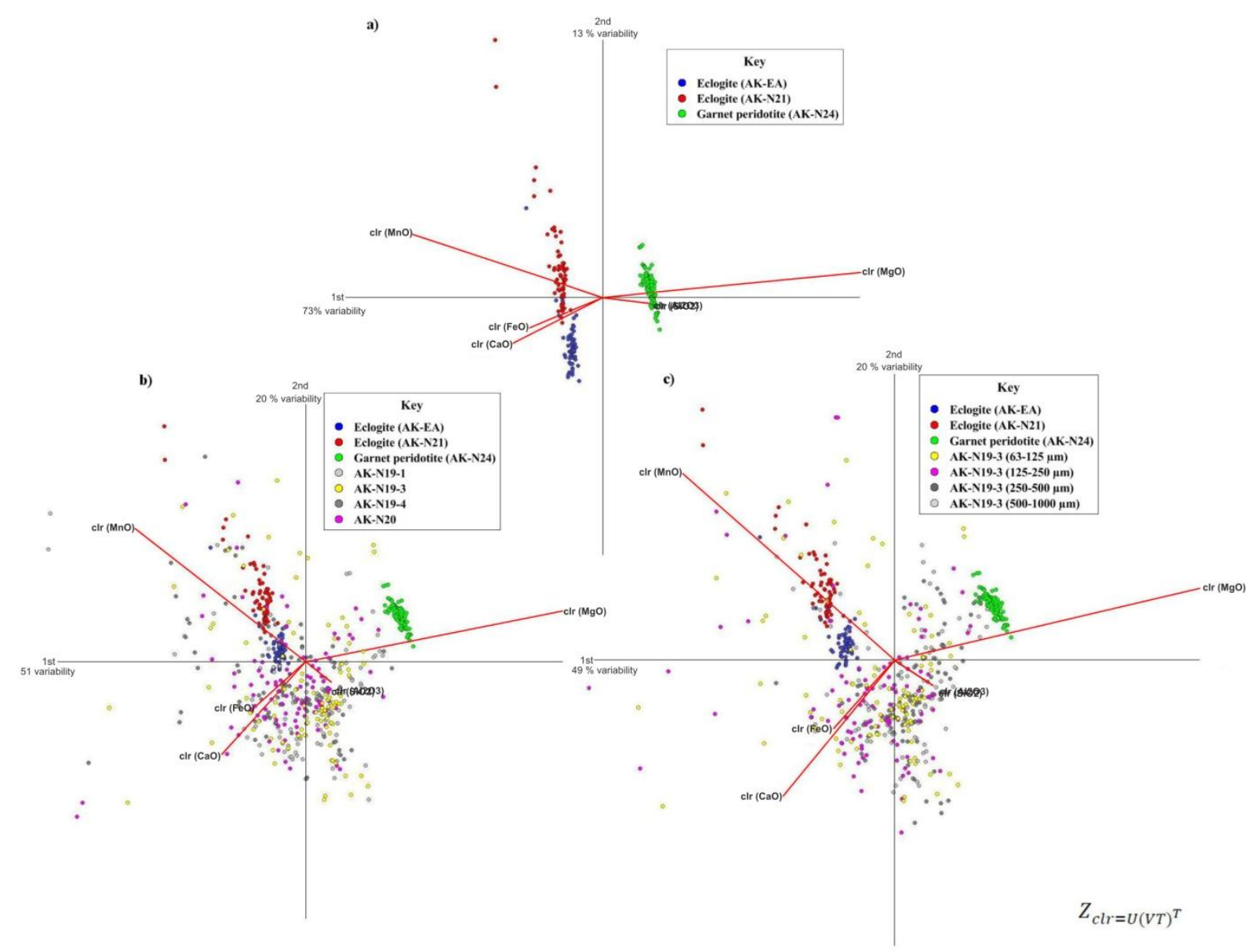

Fig. 5. Compositional biplot of garnets based on major elements $\mathrm{Al} 2 \mathrm{O} 3, \mathrm{SiO} 2, \mathrm{CaO}, \mathrm{FeO}, \mathrm{MnO}$ and $\mathrm{MgO}$. Axes are the first and second principal components (PC). (a) Compositional biplot of garnet grains from the bedrocks. Almost $73 \%$ of the variability is explained by the first PC and $13 \%$ by the second PC. (b) Compositional biplot of detrital garnet grains from the bedrocks and from all stream sediments of the $63-125 \mu \mathrm{m}$ grain size fraction. Almost $51 \%$ of the variability is explained by the first PC and $20 \%$ by the second PC. (c) Compositional biplot from sample AK-N19-3 of the 63-125 $\mu \mathrm{m}$, $125-250 \mu \mathrm{m}, 250-500 \mu \mathrm{m}$ and $500-1000 \mu \mathrm{m}$ grain size fractions. Almost $49 \%$ of the variability is explained by the first PC and $20 \%$ by the second PC.

Garnet composition from stream sediments and bedrocks is illustrated in the classical ternary classification diagram using almandine + spessartine, pyrope, and grossular as poles, and the discrimination fields $\mathrm{A}, \mathrm{B}, \mathrm{Bi}, \mathrm{Ci}, \mathrm{Cii}$, and $\mathrm{D}$ (Mange and Morton, 2007; Fig. 6). This diagram has widely been applied in a number of garnet provenance studies (e.g., Whitham et al., 2004; Morton et al., 2005, 2011; Mange and Morton, 2007; Meinhold et al., 2010; Krippner et al., 2015). All of the garnets of samples AK-EA and almost all of the garnets of sample AK-N21 plot in field $\mathrm{Ci}$, the field for garnets derived from high-grade mafic rocks, such as eclogites. Garnets of 
sample AK-N24 plot in field Cii, the field for garnets derived from ultramafic rocks (Fig. 6a).

For comparison, all garnets from the stream sediments $(63-125 \mu \mathrm{m}$ grain size fraction) and from the bedrocks are plotted together in one ternary diagram (Fig. 6b). The garnets from the stream sediments overlap fields $\mathrm{B}, \mathrm{Ci}, \mathrm{A}$, and $\mathrm{Cii}$, with almost $90 \%$ of garnets plotting in field $\mathrm{Ci}$. They show a high degree of overlap with garnets measured in the eclogites. However, many detrital garnets are not comparable to the garnets derived from the eclogites as they show a wider distribution and are possibly derived from other source rocks than the measured eclogites. Interestingly, no detrital garnets are comparable with those garnets measured in the garnet peridotite (Fig. 6b).

The garnets from the different grain size fractions from sample AK-N19-3 overlap fields $\mathrm{B}, \mathrm{Bi}, \mathrm{A}, \mathrm{Ci}$, Cii, with almost $90 \%$ plotting in field $\mathrm{Ci}$. Many garnets show a high degree of overlap with garnets measured in the eclogites, but many garnets tend to higher $\mathrm{MgO}$ composition and also towards higher $\mathrm{CaO}$ or $\mathrm{FeO}+\mathrm{MnO}$ composition. Two single garnets of the $500-1000 \mu \mathrm{m}$ grain size fractions show overlap with the garnets measured in the peridotite (Fig. 6c). Overall, the detrital garnets show a distinct higher variability than the garnets from the bedrocks, and hence point to even other source rocks than the measured ones. 


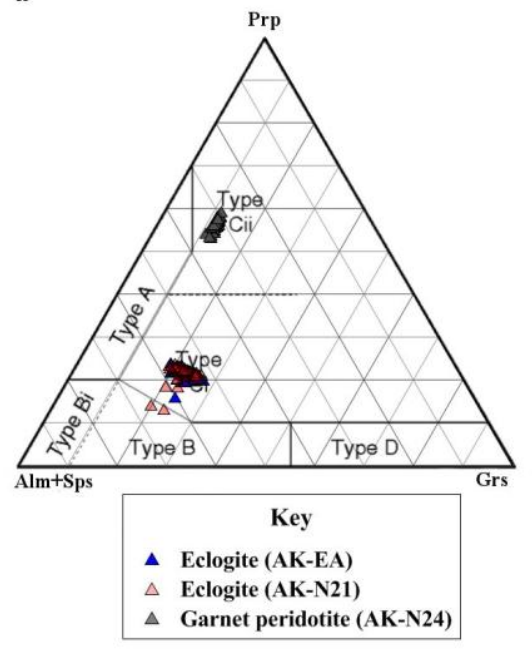

b

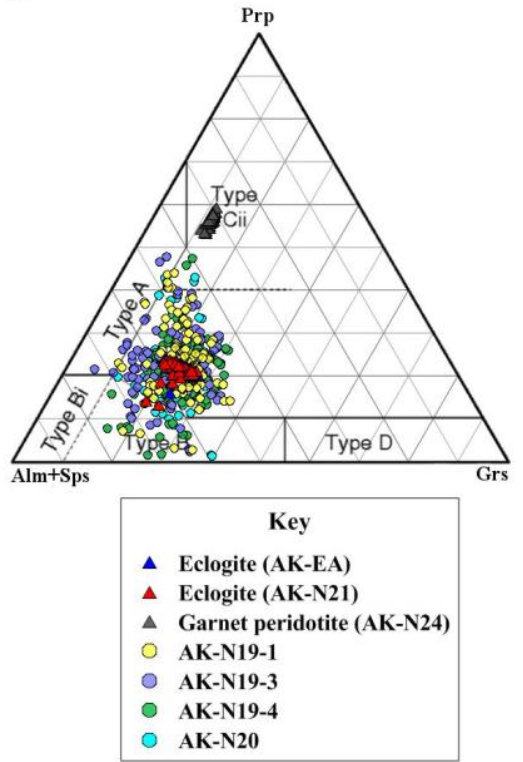

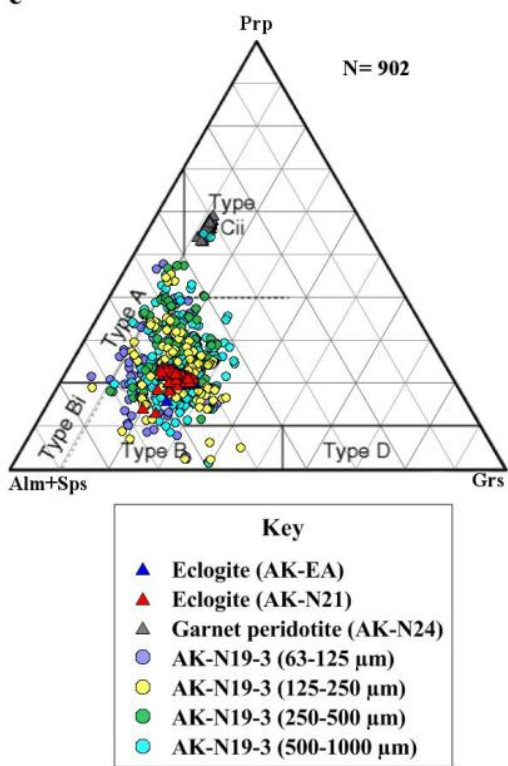

Fig. 6. Composition of garnets in the ternary classification diagram of Mange and Morton (2007) with almandine + spessartine, grossular and pyrope as poles. (a) Composition of garnets from the bedrock samples. (b) Composition of detrital garnets of the 63-125 $\mu \mathrm{m}$ grain size fraction and from the bedrock samples. (c) Composition of detrital garnets of the 125-250 $\mu \mathrm{m}, 250-500 \mu \mathrm{m}$, and 500-1000 $\mu \mathrm{m}$ grain size fraction and from the bedrock samples. A-mainly from high-grade granulite-facies metasedimentary rocks or charnockites and intermediate felsic igneous rocks; B-amphibolite-facies metasedimentary rocks; $\mathrm{Bi}$-intermediate to felsic igneous rocks; $\mathrm{Ci}$-mainly from high-grade mafic rocks; Cii-ultramafics with high Mg (pyroxenites and peridotites); D-metasomatic rocks, very lowgrade metamafic rocks and ultrahigh-temperature metamorphosed calc-silicate granulites.

With increasing grain size, the $\mathrm{MgO} / \mathrm{MnO}$ value increases on average (Fig. 7). About $6 \%$ of the garnets of the coarser grain size fractions $(250-1000 \mu \mathrm{m})$ lie above line 2 compared to $1 \%$ of the finer grain size fraction $(125-250 \mu \mathrm{m})$. None of the garnets of the $63-125 \mu \mathrm{m}$ grain size fraction lie above line 2 . In contrast, $18 \%$ of the garnets of the finer grain size fractions $(63-250 \mu \mathrm{m})$ and only $4 \%$ of the coarser grain size fractions $(250-1000 \mu \mathrm{m})$ lie below line 1 . This is because the content of $\mathrm{MnO}$ is overall higher in the finer grain size fractions $(63-250 \mu \mathrm{m})$ than in the coarser grain size fractions. In contrast, the $\mathrm{MgO}$ content of the coarser grain size fractions (250$1000 \mu \mathrm{m}$ ) is higher on average compared to the finer grain size fractions (Fig. 7). $\mathrm{MnO}$ contents exceeding $2 \mathrm{wt}$ \% are only evident in the garnets of the finer grain size fractions (63-250 $\mu \mathrm{m})$ (Supplementary Table S4). 


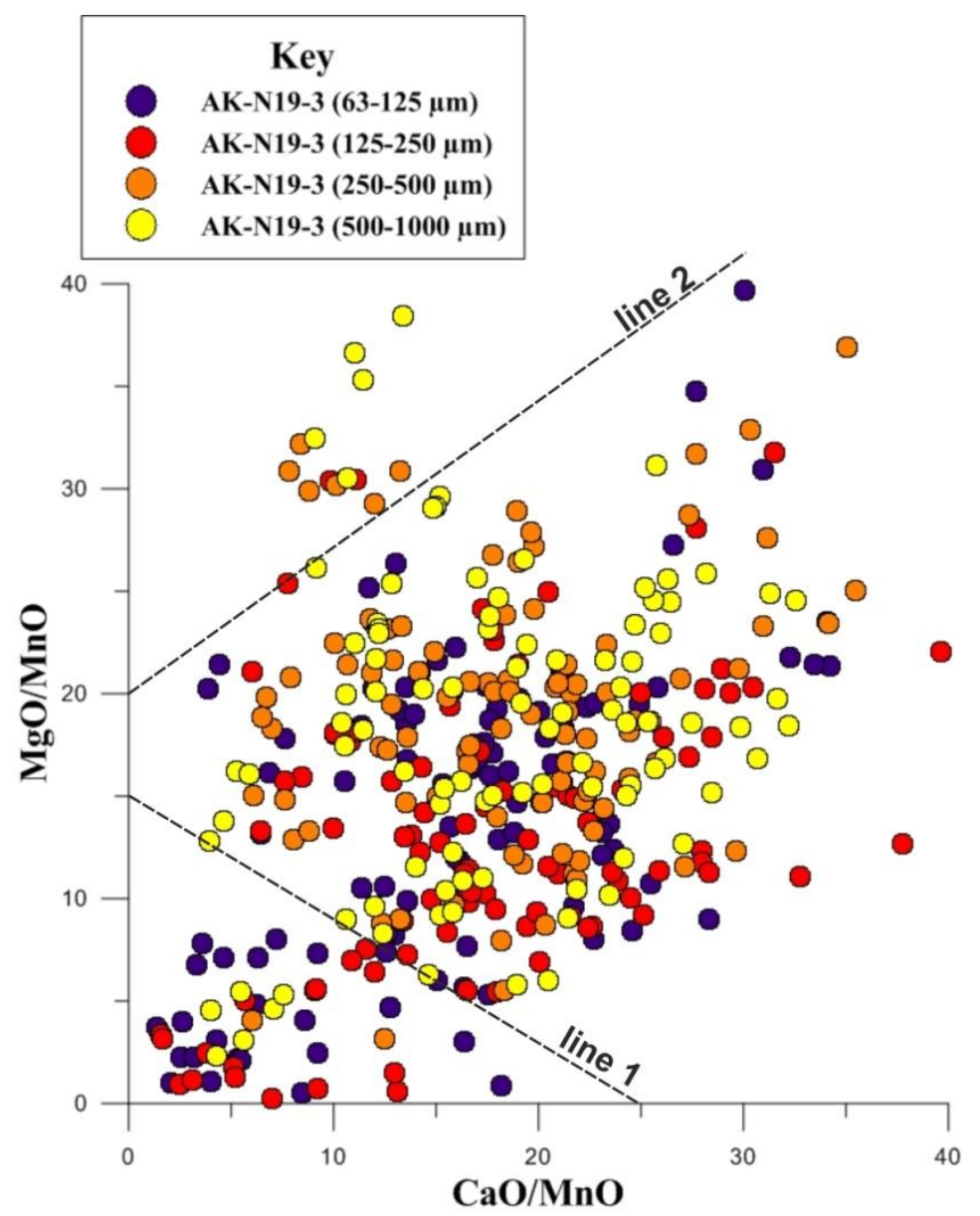

Fig. 7. Binary diagram showing $\mathrm{CaO} / \mathrm{MnO}$ vs. $\mathrm{MgO} / \mathrm{MnO}$ value of all grain size fractions of sample AKN19-3.

\section{Discussion}

Heavy mineral analysis of stream samples from the Almklovdalen area in SW Norway reveal an increase of olivine from upstream (AK-N19-4) to downstream (AK-N19-1) from $\sim 40 \%$ to $90 \%$ (Fig. 3a) and a decrease of green calcic amphibole from $\sim 13 \%$ to $\sim 1 \%$. The content of ultrastable minerals also decreases. The content of garnet slightly increases in the middle part of the river and decreases at the downstream end of the Gusdalselva river where only $1 \%$ garnet is found (sample AK-N19-1). Apatite grains decrease strongly from upstream to downstream. In sample AK-N19-4, approximately $11 \%$ of the heavy mineral assemblage consists of apatite minerals, in sample AK-N19-1, at the downstream end of the Gusdalselva river, apatite grains were not found. Epidote group minerals commonly occur in the upper section of the river $(\sim 10 \%)$, but at the downstream end of the Gusdalselva river, they are strongly depleted $(\sim 1 \%)$. The pyroxene content is nearly constant in all samples (around $10 \%)$. Most of the pyroxenes are clinopyroxenes, probably of diopsitic to augitic 
composition and likely derived from the Iherzolites (Beyer et al., 2006). However, there are also some orthopyroxenes identified which are probably of enstatitic composition.

Chlorite peridotite (dunite, harzburgite) covers a large area in the downstream part of the Gusdalselva river, including a huge quarry (Fig. 2), thus explaining the downstream increase in olivine concentration. In the upper part of the river, garnet peridotites, eclogites and gneisses are more frequent than in the downstream part of the river. Therefore, in samples AK-N19-3, AK-N19-4 and AK-N20, the influx from those rocks is higher than in sample AK-N19-1. Further downstream, most of the heavy minerals are diluted by the high input of olivine. Apatite is found in the gneisses (Table 3). There is a major input of apatite recorded in sample AK-N19-4, which is not surprising since this part of the river is draining the gneisses upstream from the sample location. The strong decrease of apatite minerals is likely due to the dilution process described previously but may also result from partial dissolution, because apatite becomes unstable under acidic conditions (Morton, 2012). The vegetation of the study area and its surroundings consist mainly of coniferous forest and indicates a rather acidic environment in which apatite is prone to dilution.

Table 3. Mineralogy of the bedrock samples.

\begin{tabular}{|l|l|l|l|l|}
\hline mineral/sample & $\begin{array}{l}\text { AK-N21 } \\
\text { (eclogite) }\end{array}$ & $\begin{array}{l}\text { AK-EA } \\
\text { (eclogite) }\end{array}$ & $\begin{array}{l}\text { AK-N24 } \\
\text { (grt-peridotite) }\end{array}$ & $\begin{array}{l}\text { AK-N25 } \\
\text { (gneiss) }\end{array}$ \\
\hline quarz & ++ & ++ & 0 & +++ \\
\hline K-feldspar & - & - & - & + \\
\hline plagioclase & 0 & 0 & - & + \\
\hline micas & 0 & 0 & ++ & 0 \\
\hline pyroxene & ++ & ++ & 0 & - \\
\hline amphibole & + & + & ++ & 0 \\
\hline olivine & + & + & +++ & - \\
\hline garnet & + & + & ++ & - \\
\hline rutile & $\mathrm{t}$ & $\mathrm{t}$ & - & + \\
\hline zircon & + & + & - & 0 \\
\hline titanite & - & - & - & + \\
\hline apatite & - & - & - & + \\
\hline
\end{tabular}

+++: very high content, ++: high content, o: low content, t: traces, -: not present

The main lithologies in the study area are dunite and harzburgite with minor garnet peridotite, eclogite and gneiss. The major garnet-bearing rocks are garnet peridotites and eclogites. In the sampled gneiss, no garnet grains were found but garnet-bearing 
gneisses are known from the surrounding area; hence, they also provide a source for the detrital garnets in the stream sediments. The detrital garnets of the 63-125 $\mu \mathrm{m}$ grain size fraction show a high degree of overlap with the garnets analysed in the eclogites (Fig. 6b). However, many of the detrital garnets cannot be directly linked to the studied eclogites. A possible explanation is that the several eclogite bodies exposed in the area cover a range of different garnet compositions, which is also evident from the two measured eclogites as seen in the biplots because they can be clearly separated from each other (Fig. 5a). This separation is only possible when $\mathrm{FeO}$ and $\mathrm{MnO}$, respectively, almandine and spessartine, are not combined. That is why a discrimination of both eclogites cannot be determined in the ternary diagrams. Garnets with a high $\mathrm{MnO}$ and a low $\mathrm{MgO}$ content can be probably linked to the garnet-bearing gneisses, which suffered lower grade amphibolite-facies metamorphism (Bryhni and Andréasson, 1985; Krabbendam and Wain, 1997; Krabbendam et al., 2000). There is no overlap of detrital garnets with the garnets from the garnet peridotite. This suggests that the eclogites and the gneisses are the main source of the detrital garnets. Due to the fact that the grain size of the garnets in the garnet peridotite is coarser (the short axis of the smallest grain is > $1000 \mu \mathrm{m}$ ) than the garnets in the studied 63-125 $\mu \mathrm{m}$ grain size fraction, it is not very likely that these garnets occur in this grain size fraction. Certainly, coarse-grained source rock garnets, crushed through hydraulic or other mechanical processes, can occur in the finer grain size fractions, but less likely than garnets with an original finer size distribution in the source rocks. In contrast, garnets of original finer size distribution in the source rocks cannot be expected in the coarse grain size fractions. Therefore, it can be assumed that lower grade metamorphic garnets, possibly derived from the garnet-bearing gneisses, are generally finer, because almandine garnets with higher $\mathrm{MnO}$ content are more frequent in the finer grain size fractions (Fig. 7). In the ternary diagram, only two detrital garnets of the very coarse $500-1000 \mu \mathrm{m}$ grain size fraction overlap with the garnets from the peridotites (Fig. 6c). In the biplots (Fig. 5c), this number is slightly higher and also includes grains from the 250-500 $\mu \mathrm{m}$. Therefore, a general coarse grain size of garnets from the garnet peridotites exposed in this area can be assumed, as observed in the bedrock sample AK-N24, too. The fact that only grains from the coarse grain size fractions show overlap with the garnet peridotite (Figs. 5c, 6c) is likely due to the inheritance of grain size from source rock to sediment. Alternatively, the peridotites contribute only little detritus to the sediment 
and the number of 50 garnets measured from the $63-125 \mu \mathrm{m}$ grain size fraction is insufficient to detect them. As an effect of hydraulic sorting during settling, heavy minerals concentrate in specific grain size classes (Rubey, 1933; Rittenhouse, 1943; Garzanti et al., 2008; Resentini et al., 2013). The specific endmembers of garnet show different densities, with the highest density of $\sim 4.3 \mathrm{~g} / \mathrm{cm} 3$ for almandine garnets, $4.2 \mathrm{~g} / \mathrm{cm} 3$ for spessartine garnets and $3.6 \mathrm{~g} / \mathrm{cm} 3$ for pyrope garnets (Deer et al., 1992). Commonly, garnets with a higher density are found in the fine tail of the grain size distribution in contrast to less dense garnet species (Schuiling et al., 1985; Andò, 2007; Garzanti et al., 2008). Due to the fact that the less dense pyrope-rich almandine garnet is more frequent in the coarse grain size fraction, hydraulic sorting according to their density can be excluded and it is more likely that this is an effect of grain size distribution in the source rocks.

The short axes of the garnets lie within the expected interval of $63-125 \mu \mathrm{m}$, except for a few grains. The long axes show a wider distribution in their sizes (> 80-260 $\mu \mathrm{m})$ (Fig. 4; Table 2). Most of the long axes (38\%-86\%) are longer in size than the sieved grain size fraction (Fig. 4; Table 2). This means that a wet-sieved sample is only separated by the short axes of the minerals. Therefore, it is possible that grains with a short axis of $120 \mu \mathrm{m}$ and a long axis of $480 \mu \mathrm{m}$, for instance, occur in the 63$125 \mu \mathrm{m}$ grain size fraction although their average grain size may be around $300 \mu \mathrm{m}$. The highest concentration of garnet grains occur in the $125-500 \mu \mathrm{m}$ grain size fraction (Fig. 3b). This also points, in contrast to, e.g., apatite, to a generally coarser garnet grain size in the source rocks.

\section{Conclusions}

The heavy mineral assemblages reflect the geological situation in the area of Almklovdalen. The dominant heavy mineral is olivine. From upstream to downstream the content of olivine strongly increases, whereas the content of all other heavy minerals found in the samples strongly decreases. This is because in the upstream part of the sampled river the diversity of potential source rocks is higher than in the downstream part of the river where the proportion of dunite and chlorite peridotite is much higher. Garnets with high MgO content are more frequent in the coarse grain size fractions, which likely result from the inheritance of grain size from source rock to sediment. However, only very few garnets of the 250-1000 $\mu \mathrm{m}$ grain size fractions show full overlap with the garnets from the garnet peridotite sample. In contrast, 
garnets with high $\mathrm{MnO}$ content are more frequent in the fine grain size fractions. Therefore, analysing a wide grain size window is of paramount importance, as also discussed in other studies (e.g., Garzanti et al., 2009; Krippner et al., 2015), because we can miss information contained in other grain size fractions.

\section{Acknowledgments}

The PhD scholarship of AK is financed by CASP. Fieldwork and analytical work was financed by the German Research Foundation (DFG grant EY 23/20-1). We thank Andreas Kronz for his help with EMP analyses. Constructive reviews were provided by Sergio Andò and Alberto Resentini.

\section{References}

Aitchison, J., 1986. The Statistical Analysis of Compositional Data, Monographs on Statistics and Applied Probability. Chapman \& Hall Ltd., London, 416 pp.

Andersen, T.B., Jamtveit, B., Dewey, J.F., Swensson, E., 1991. Subduction and eduction of continental crust: major mechanism during continent-continent collision and orogenic collapse, a model based on the south Norwegian Caledonides. Terra Nova 3, 303-310.

Andò, S., 2007. Heavy minerals: provenance, hydraulic sorting, weathering. Unpublished PhD Thesis, University of Milano-Bicocca, $210 \mathrm{pp}$.

Andò, S., Garzanti, E., Padoan, M., Limonta, M., 2012. Corrosion of heavy minerals during weathering and diagenesis: A catalog for optical analysis. Sedimentary Geology 208, 165-178.

Beyer, E.E., Brueckner, H.K., Griffin, W.L., O'Reilly, S.Y., Graham, S., 2004. Archean mantle fragments in Proterozoic crust, Western Gneiss Region, Norway. Geology 32, 609-612.

Beyer, E.E., Griffin, W.L., O'Reilly, S.Y., 2006. Transformation of Archean lithospheric mantle by refertilization: Evidence from exposed peridotites in the Western Gneiss Region, Norway. Geology 32, 609-612.

Beyer, E.E., Brueckner, H.K., Griffin, W.L., O'Reilly, S.Y., 2012. Laurentian Provenance of Archean Mantle Fragments in the Proterozoic Baltic Crust of the Norwegian Caledonides. Journal of Petrology 53, 1357-1383. 
Brueckner, H.K., Carswell, D.A., Griffin, W.L., 2002. Paleozoic diamonds within a Precambrian peridotite lens in UHP gneissesof the Norwegian Caledonides. Earth and Planetary Science Letters 203, 805-816.

Brueckner, H.K., Carswell, D.A., Griffin, W.L., Medaris, L.G., van Roermund, H.L.M., Cuthbert, S.J., 2010. The mantle and crustal evolution of two garnet peridotite suites from the Western Gneiss Region, Norwegian Caledonides: an isotopic investigation. Lithos 117, 1-19.

Bryhni, I., Andréasson, P.G, 1985. Metamorphism in the Scandinavian Caledonides. In: Gee, D.G., Sturt, B.A. (Eds.). The Caledonide Orogen - Scandinavia and Related Areas. Wiley, Chichester, 763-781.

Carswell, D.A., 1986. The metamorphic evolution of $\mathrm{Mg}-\mathrm{Cr}$ type Norwegian garnet peridotites. Lithos 19, 279-297.

Carswell, D.A., Cuthbert, S.J., 2003. Review of the mineralogical and microstructural evolution of ultra-high pressure eclogites in the Western Gneiss Region of Norway. In: Carswell, D.A., Cuthbert, S.J., Krabbendam, M., Medaris, L.G., Brueckner, H.K. (Eds.), Guidebook to the Field Exkursions in the Nordfjord Stadtlandet - Almklovdalen Area. NGU Report, pp. 3-47.

Comas-Cufí, M., Thió-Henestrosa, S., 2011. CoDaPack 2.0: a stand-alone, multiplatform compositional software. In: Egozcue, J.J., Tolosana-Delgado, R., Ortego, M.I. (Eds.), CoDaWork'11: 4th International Workshop on Compositional Data Analysis. Sant Feliu de Guíxols.

Cordellier, F.M., Boudier, F., Boullier, A.M., 1981. Structural study of the Almklovdalen peridotite massif (southern Norway). Tectonophysics 77, 257-281.

Cuthbert, S.J., Carswell, D.A., Krogh-Ravna, E.J., Wain, A. 2000. Eclogites and eclogites of the Western Gneiss Region, Norwegian Caledonides. Lithos 52, 165-195.

Deer, W.A., Howie, R.A., Zussman, J., 1992. An introduction to rock-forming minerals. Longman Group Ltd, Harlow, UK, 712 pp.

Eskola, P., 1921. On the eclogites of Norway. Skrifter udgivne af VidenskabsSelskapet i Christiana, Matematisk-Naturvidenskapelig Klasse 8, 1-118.

Garzanti, E., Andò, S., Vezzoli, G., 2008. Settling-equivalence of detrital minerals and grain-size dependence of sediment composition. Earth and Planetary Science Letters 273, 138-151. 
Garzanti, E., Andò, S., Vezzoli, G., 2009. Grain-size dependence of sediment composition and environmental bias in provenance studies. Earth and Planetary Science Letters, 277, 422-432.

Garzanti, E., Limonta, M., Resentini, A., Bandopadhyay, P.C., Najman, Y., Andò, S., Vezzoli, G., 2013. Sediment recycling at convergent plate margins (Indo-Burman Ranges and Andaman-Nicobar Ridge. Earth-Science Reviews 123, 113-132.

Gebauer, D., Lappin, M.A., Grunenfelder, M., Wyttenbach, A. 1985. The age and origin of some Norwegian eclogites: a U-Pb zircon and REE study. Chemical Geology 52, 22-47.

Griffin, W.L., Brueckner, H.K., 1980. Caledonian Sm-Nd ages and a crustal origin of Norwegian eclogites. Nature 285, 319-21.

Griffin, W.L., Qvale, H., 1985. Superferrian eclogites and the crustal origin of garnet peridotites. Almklovdalen, Norway. In: Gee, D.G., Sturt, B.A. (Eds.). The Caledonide Orogen - Scandinavia and Related Areas. Wiley, Chichester, 763-781.

Griffin, W.L., Austrheim, H., Brastad, K., Bryhni, I., Krill, A.G., Krogh, E.J., Mørk, M.B.E., Qvale, H., Torudbakken, B., 1985. High-pressure metamorphism in the Scandinavien Caledonides. In: Gee, D.G., Sturt, B.A. (Eds.). The Caledonide Orogen - Scandinavia and Related Areas. Wiley, Chichester, pp. 783-801.

Grütter, H.S., Gurney, J.J., Menzies, A.H., Winter, F., 2004. An updated classification scheme for mantle-derived garnets, for use by diamond explorers. Lithos 77 , 841-857.

Gurney, J.J., 1984. A correlation between garnets and diamonds. In: Glover, J.E., Harris, P.G. (Eds.), Kimberlite occurrence and origins: a Basis for Conceptual Models in Exploration. Geology Department and University Extension, University of Western Australia, Publication 8, 143-166.

Krabbendam, M., Wain, A., 1997. Late-Caledonian structures, differential regression and structural position of (ultra)high-pressure rocks in the Nordfjord-Stradlandet area, Western Gneiss Region. Norges Geologiske Undersøkelse 432, 127-139.

Krabbendam, M., Wain, A., Andersen, T.B., 2000. Pre-Caledonian granulite and gabbro enclaves in the Western Gneiss Region, Norway: indications of incomplete transition at high pressure. Geological Magazine 137, 235-255. 
Krippner, A., Meinhold, G., Morton, A.C., von Eynatten, H., 2014. Evaluation of garnet discrimination diagrams using geochemical data derived from various host rocks. Sedimentary Geology 306, 36-52.

Krippner, A., Meinhold, G., Morton, A.C., Russell, E., von Eynatten, H., 2015. Grainsize dependence of garnet composition revealed by provenance signatures of modern stream sediments from the western Hohe Tauern (Austria). Sedimentary Geology 321, 25-38.

Krogh, E.J., 1977. Evidence for a Precambrian continent-continent collision in western Norway. Nature 267, 17-19.

Mange, M.A., Maurer, H.F.W., 1992. Heavy Minerals in color, Chapman and Hall, London, pp 147.

Mange, M.A., Morton, A.C., 2007. Geochemistry of heavy minerals. In: Mange, M.A., Wright, D.T. (Eds.), Heavy Minerals in Use. Developments in Sedimentology 58, Elsevier, Amsterdam, pp. 345-391.

Mange, M.A., Wright, D.T., 2007. Heavy Minerals in Use. Developments in Sedimentology 58, Elsevier, Amsterdam, pp 1329.

Medaris, L.G., 1984. A geothermobarometric investigation of garnet peridotites in the Western Gneiss Region of Norway. Contributions to Mineralogy and Petrology 87, 72-86.

Medaris, L.G., Carswell, D.A., 1990. The petrogenesis of Mg-Cr garnet peridotites in European metamorphic belts. In: Carswell, D.A. (Ed.), Eclogite Facies Rocks. New York, Chapman and Hall, pp. 260-290.

Medaris, L.G., Brueckner, H.K., 2003. Excursion to the Almklovdalen Peridotite. In: Carswell, D.A., Cuthbert, S.J., Krabbendam, M., Medaris, L.G., Brueckner, H.K. (Eds.), Guidebook to the Field Exkursions in the Nordfjord - Stadtlandet Almklovdalen Area, NGU Report, pp 109-133.

Meinhold, G., Reischmann, T., Kostopoulos, D., Frei, D., Larionov, A.N., 2010. Mineral chemical and geochronological constraints on the age and provenance of the eastern Circum-Rhodope Belt low-grade metasedimentary rocks, NE Greece. Sedimentary Geology 229, 207-223.

Mørk, M.B.E., Mearns, E.W., 1985. Sm-Nd isotopic systematics of a gabbro-eclogite transition. Lithos 19, 255-267. 
Morton, A.C., 1985. A new approach to provenance studies: electron microprobe analysis of detrital garnets from Middle Jurassic sandstones of the northern North Sea. Sedimentology 32, 553-566.

Morton, A.C., 2012. Value of heavy minerals in sediments and sedimentary rocks for provenance, transport history and stratigraphic correlation. In: Sylvester, P. (Ed.), Quantitative Mineralogy and Microanalysis of Sediments and Sedimentary Rocks. Mineralogical Association of Canada Short Course Series 42, pp. 133165.

Morton, A.C., Hallsworth, C.R., 1999. Processes controlling the composition of heavy mineral assemblages in sandstones. Sedimentary Geology 124, 3-29.

Morton, A.C., Whitham, A.G., Fanning, C.M., 2005. Provenance of Late Cretaceous to Paleocene submarine fan sandstones in the Norwegian Sea: integration of heavy mineral, mineral chemical and zircon age data. Sedimentary Geology 182 , 3-28.

Morton, A.C., Meinhold, G., Howard, J.P., Phillips, R.J., Strogen, D., Abutarruma, Y., Elgadry, M., Thusu, B., Whitham, A.G., 2011. A heavy mineral study of sandstones from the eastern margin of the Murzuq Basin, Libya: constraints on provenance and stratigraphic correlation. Journal of African Earth Sciences 61, 308-330.

Nowicki, T., Dyck, D., Carlson, J., Helmstaedt, H., 2003. The geology of kimberlite pipes of the Ekati property, Northwest Territories, Canada. Lithos 76, 1-27.

Osland, R., 1997. Modelling of variations in Norwegian olivine deposits, causes of variation and estimation of key quality factors. Doktor Ingeniør thesis, Norwegian University of Science and Technology, 189 pp.

Pettijohn, F.J., 1941. Persistence of heavy minerals and geological age. Journal of Geology 49, 610-625.

Resentini, A., Malusà, M.G., Garzanti, E., 2013. MinSORTING: An Excel® worksheet for modelling mineral grain-size distribution in sediments, with application to detrital geochronology and provenance studies. Computers \& Geosciences 59, 90-97.

Rittenhouse, G., 1943. Transportation and deposition of heavy minerals. Geological Society of American Bulletin 54 (12), 1725-1780. 
Roberts, D.C., Gee, D.G., 1985. An introduction to the structure of the Scandinavian Caledonides. In: Gee, D.G., Sturt, B.A. (Eds.), The Caledonide Orogen Scandinavia and Related Areas. Wiley, Chichester, 55-68.

Root, D.B., Hacker, B.R., Gans, P.B., Duccea, M.N., Eide, E.A., Mosenfelder, L., 2005. Discrete ultrahigh-pressure domains in the Western Gneiss Region, Norway: Implications for formation and exhumation. Journal of Metamorphic Geology 23, 45-61.

Rubey, W.W., 1933. The size-distribution of heavy minerals within a water-laid sandstone. Journal of Sedimentary Research 3, 3-29.

Schuiling, R.D., de Meijer, R.J., Riezebos, H.J., Scholten, M.J., 1985. Grain-size distribution of different minerals in a sediment as a function of their specific density. Geologie en Mijnbouw 64, 199-203.

Thió-Henestrosa, S., Martín-Fernández, J.A., 2005. Dealing with compositional data: the freeware CoDaPack. Mathematical Geology 37, 773-793.

Tucker, R.D., Krogh, T.E., Råheim, A., 1990. Proterozoic evolution and age-province boundaries in the central part of the Western Gneiss Region, Norway; results of $\mathrm{U}-\mathrm{Pb}$ dating of accessory minerals from Trondheimsfjord to Geieranger. In: Gower, C.F., Rivers, T., Ryan, B. (Eds.), Mid-Proterozoic Laurentia-Baltica. Geological Association of Canada, Special Paper 38, 149-73.

van Andel, T.H., 1950. Provenance, Transport and Deposition of Rhine Sediments: A Heavy Mineral Study on River Sands from the Drainage Area Of The Rhine. Dissertation, Rijksuniversiteit te Groningen, Wageningen, Veenman \& Zonen, $129 \mathrm{pp}$.

Velbel, M.A., 1984. Natural weathering mechanisms of almandine garnet. Geology $12(10), 631-634$

Velbel M.A., 1999. Bond strength and the relative weathering rates of simple orthosilicates. American Journal of Science 299, 679-696.

Velbel, M.A., 2007. Surface textures and dissolution processes of heavy minerals in the sedimentary cycle: examples from pyroxenes and amphiboles. In: Mange, M., Wright, D.K. (Eds.), Heavy Minerals In Use. Developments in Sedimentology 58, Elsevier, Amsterdam, pp. 112-150.

von Eynatten, H., Barceló-Vidal, C., Pawlowsky-Glahn, V., 2003. Composition and discrimination of sandstones: A statistical evaluation of different analytical methods. Journal of Sedimentary Research 73, 47-57. 
von Eynatten, H., Dunkl, I., 2012. Assessing the sediment factory: the role of single grain analysis. Earth-Science Reviews 115, 97-120.

Whitham, A.G., Morton, A.C., Fanning, C.M., 2004. Insights into CretaceousPalaeogene sediment transport paths and basin evolution in the North Atlantic from a heavy mineral study of sandstones from southern East Greenland. Petroleum Geoscience 10, 61-72.

Wright, W.I., 1938. The composition and occurrence of garnets. American Mineralogist 23, 436-449 


\section{Manuscript IV: Provenance signatures of stream sediments and composition of HP-UHP bedrocks from the Western Gneiss Region, SW Norway}

Anne Krippner ${ }^{1, *}$, Guido Meinhold ${ }^{1}$, Andrew C. Morton ${ }^{2,3}$, Hilmar von Eynatten ${ }^{1}$

${ }^{1}$ Department of Sedimentology and Environmental Geology, University of Göttingen, Goldschmidtstraße 3, 37077 Göttingen, Germany

${ }^{2}$ CASP, West Building, 181A Huntingdon Road, Cambridge CB3 ODH, United Kingdom

${ }^{3} \mathrm{HM}$ Research Associates, 2 Clive Road, Balsall Common, West Midlands CV7 7DW, United Kingdom

Submitted to Norwegian Journal of Geology

\section{Abstract}

We present heavy mineral and garnet geochemical data of recent stream sediments and HP-UHP bedrocks from the Flatraket and Ulvesund bodies and from the island of Runde, Western Gneiss Region, SW Norway, to test to what extent the heavy minerals and the garnet geochemistry in stream sediments reflect the geological situation in the source area. The heavy mineral assemblages of the stream sediments contain garnet, green calcic amphibole, and epidote-group minerals, which reflect greenschist and higher grade metamorphism in the source area. The geochemical data of garnets point to high grade metamorphic conditions. Overall, the heavy mineral and garnet geochemical data very well reflect the geological situation in the source area, which confirms the application and the importance of heavy minerals in sedimentary provenance analysis. Geochemical data of heavy minerals usually show a wider distribution in the sediments than the data of heavy minerals measured in the bedrocks. However, our results demonstrate that this is not always the case. Some garnets measured in the bedrocks, especially lower grade and ultrahigh grade metamorphic garnets are only of secondary importance or they are 
lacking in the sediments. This is probably because lower grade metamorphic gneisses, although they are dominant in the source areas, only sporadically contain garnets, or because the grain-size of garnets in these rocks is larger than the studied grain-size window of the sediments. Ultrahigh grade metamorphic rocks are only rarely exposed in the source areas. Therefore, we conclude that detrital minerals derived from lower and/or ultrahigh grade metamorphic rocks are diluted by the input from garnets of bedrocks containing granulite- and eclogite-facies assemblages, which carry high amounts of garnet.

\section{Introduction}

Detrital heavy minerals from sediments provide insights in the entire catchment area. Several techniques exist to analyse different mineral grains and every single grain preserves important palaeographic information about the tectonic and erosional history of source areas (e.g., Garzanti et al., 2009; von Eynatten et al., 2012). However, numerous interferences can affect the original signal of the grains from the source rocks caused by processes during the sedimentary cycle (e.g., Morton and Hallsworth, 1999). Therefore, it is particularly important to learn more about these processes and to find ways to minimize potential bias. In this study, we sampled three different small catchment areas in the Western Gneiss Region in order to test the application of heavy minerals and garnet geochemistry for the commonly used grain-size fraction of 63-125 $\mu \mathrm{m}$. Some studies have shown that a narrow grain size can represent misleading short cuts, because through physical processes detrital minerals are segregated according to their size, density and shape (Morton and Hallsworth, 1999; Garzanti et al., 2008, 2009, 2010), even within a single mineral group (Schuiling et al., 1985; Andò, 2007; Garzanti et al., 2008). However, because sampling and sample preparation can be very time consuming, we want to test whether we are able to state assumptions about the geology of the source area, when only one sample is available and if only one grain-size fraction of the sample is considered. Garnet is very useful in sedimentary provenance analysis, because it exists in many different types of rock and its chemical composition can be correlated with the conditions under which the source rocks were formed (e.g., Andó et al., 2014; Krippner et al., 2014). With increasing pressure and temperature conditions in the source area, garnet shows progressive substitution from $\mathrm{Mn}^{2+}$ to $\mathrm{Fe}^{2+}$ and $\mathrm{Mg}^{2+}$ (Miyashiro, 1953; Nandi, 1967; Deer et al. 1982; Andó et al., 2014). Therefore, garnet 
has important provenance applications. However, there exist some overlaps between different garnet assemblages, which need to be considered carefully (see Krippner et al., 2014).

\section{Geological setting}

The Scandinavian Caledonides were formed during the continental collision between Baltica and Laurentia under closure of lapetus Ocean during the Silurian (e.g., Roberts and Gee, 1985; Brueckner and van Roermund, 2004; Root et al., 2005, Spengler et al., 2009). The Western Gneiss Region (WGR) is generally interpreted to represent the westward continuation of the Fennoscandian basement of Baltica. During the Scandian phase (435-390 Ma) of the Caledonian orogeny, the subduction of Baltica beneath Laurentia produced high-pressure (HP) and ultrahigh-pressure (UHP) rocks (Griffin and Brueckner, 1980, 1985; Gebauer et al., 1985; Mørk and Mearns, 1986; Andersen et al., 1991; Krabbendam et al., 2000; Terry and Robinson, 2004). The depth of subduction increases towards the NW (Andersen et al., 1991; Brueckner, 1998; Brueckner and van Roermund, 2004; Hacker et al., 2010; Beyer et al., 2012) (Fig. 1). Most of the rocks of the WGR consist mainly of granodioritic to granitic orthogneisses and are considered to be Baltica basement (Tucker et al., 1990). The gneisses are predominantly of amphibolite-facies metamorphic grade (Bryhni and Andréasson, 1985; Krabbendam and Wain, 1997; Krabbendam et al., 2000), but in some parts granulite-facies assemblages occur (Griffin et al, 1985; Krabbendam et al., 2000). The orthogneisses are locally overlain by pelitic paragneisses, but they are only very scarce (Carswell and Cuthbert, 2003). Within the gneisses eclogite lenses and pods occur but they make up only 1 vol. \% of the HP-UHP terrane (Root et al., 2005). Following the UHP event, rocks of the WGR suffered a strong amphibolite-facies recrystallisation. Most of the eclogites are not affected by this event, but many of the UHP minerals were replaced by amphibolitefacies minerals. 


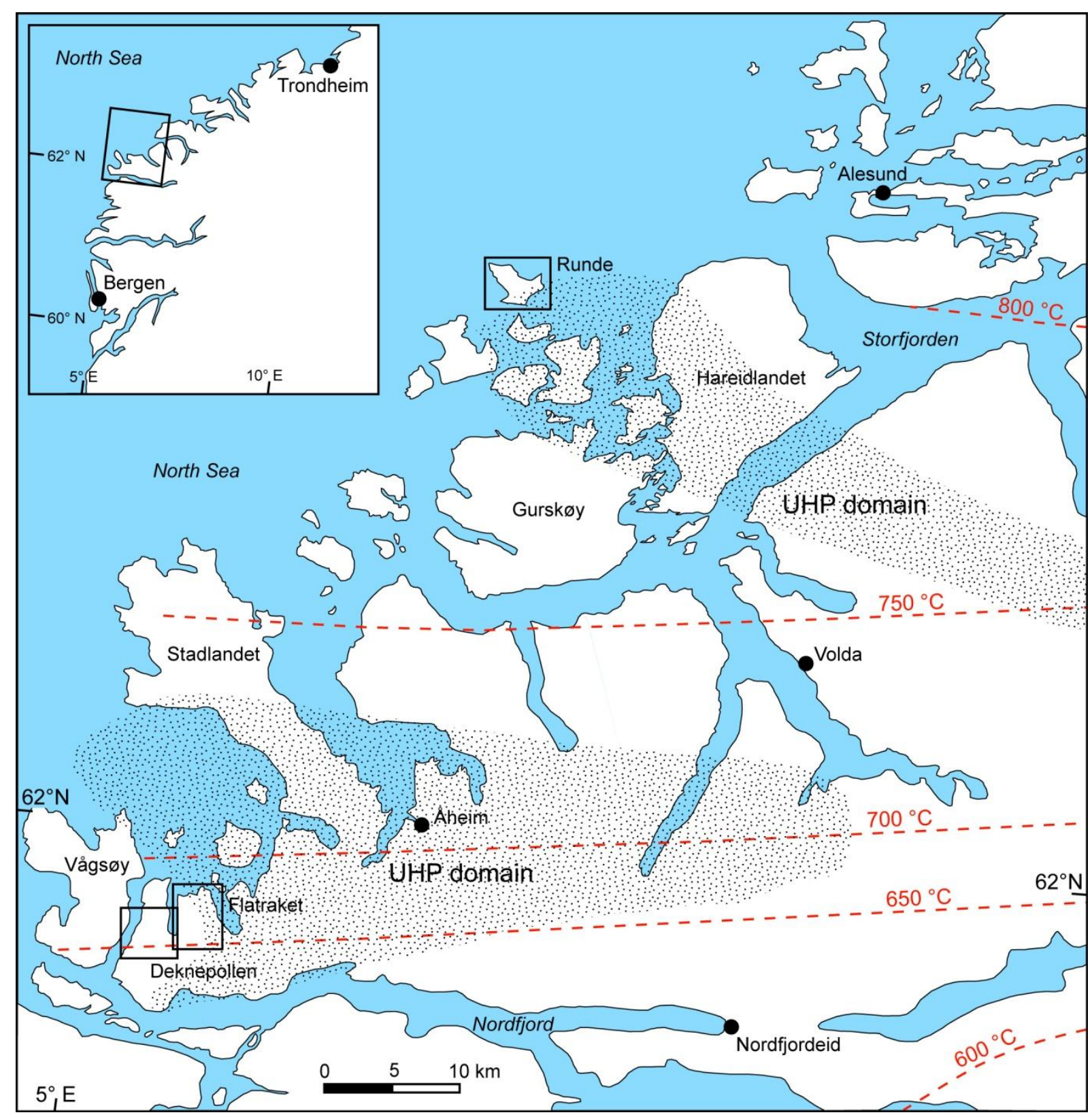

Fig. 1. Map of the Western Gneiss Region showing ultrahigh-pressure (UHP) domains and peak metamorphic temperature isolines (after Root et al., 2005; Kylander-Clark et al., 2008; Wang et al., 2013). Boxes indicate locations of the study areas.

\section{Sampling areas}

Samples were collected from two drainage systems in the Nordfjord-Stadlandet area and from the island of Runde off the coast SW of Alesund (Fig. 1).

\subsection{Flatraket}

The Flatraket body (Fig. 2) is located within the UHP domain (Root et al., 2005) and the mixed HP-UHP transition zone (Wain, 1997) and preserves pre-Caledonian igneous and granulite-facies assemblages, which experienced no or only little 
Caledonian deformation (Krabbendam et al., 2000). The main rock type of the Flatraket body is micaceous quartzo-feldspathic gneiss with megacrystic K-feldspar in its core equilibrated under amphibolite-facies conditions (Krabbendam et al., 2000). This gneiss is surrounded by a transition zone composed of felsic granulite gneisses. Within these gneisses layers and pods of dioritic, anorthositic and mafic composition are preserved. The eclogites make up c. $5 \%$ of the Flatraket body and are partially retrogressed to amphibolite-facies assemblages. Also the granulite is strongly affected by amphibolite-facies retrogression (Krabbendam and Wain, 1997; Wain et al., 2001).

The stream sample (AK-N13-1) was taken where the main river enters the sea (Fig. 2). Additionally, some source rocks were taken for comparison. Sample AK-N-11 is a granulite and sample AK-N-12 is a UHP eclogite taken in outcrop; samples AK-N132a, AK-N13-2b, AK-N13-2c and AK-N13-2d are pebbles taken from the river bed. Pebbles AK-N13-2a and AK-N13-2b are of eclogitic composition, samples AK-N13$2 c$ and AK-N13-2d are gneisses. The geographic coordinates of all samples are given in Table 1. 


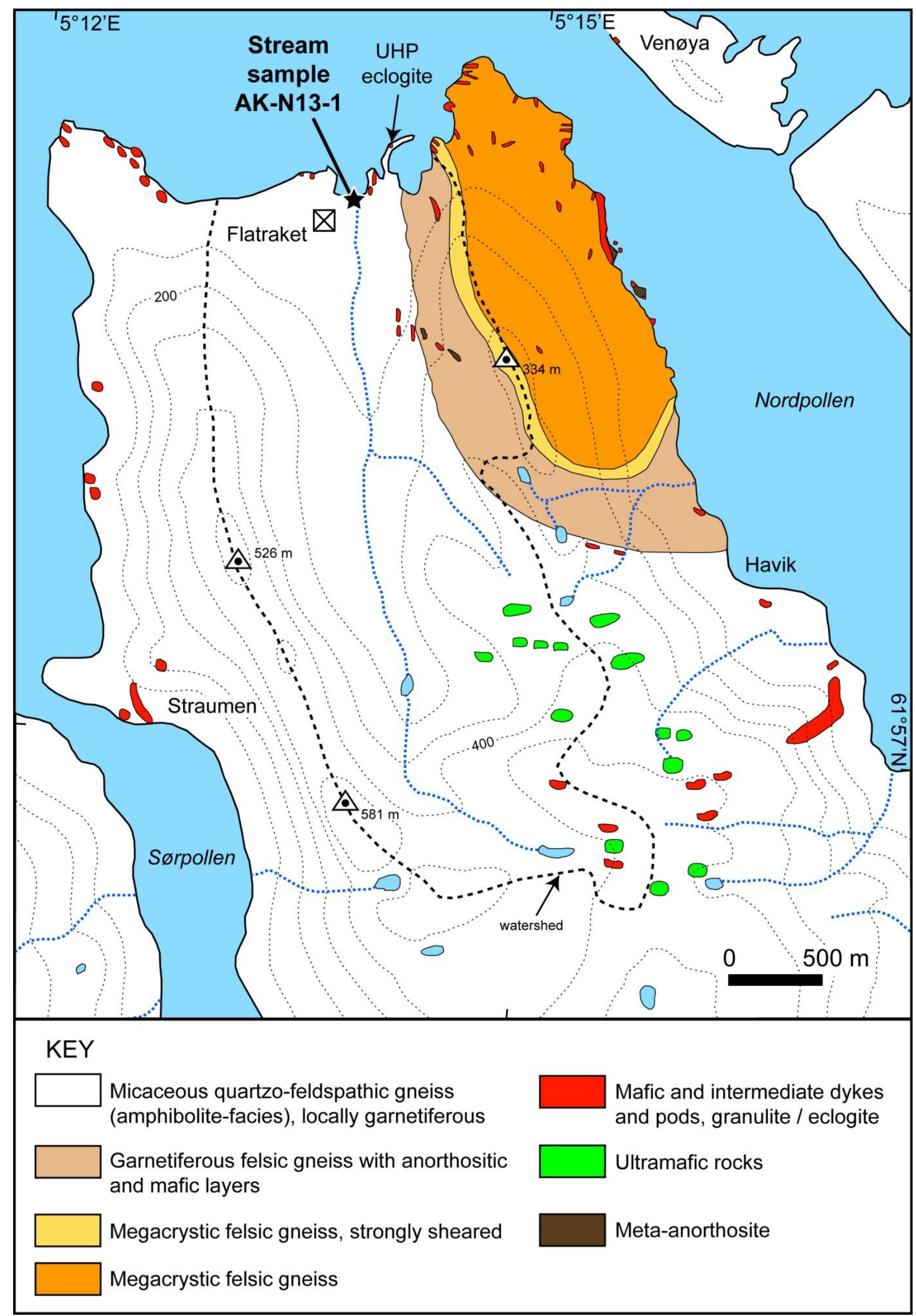

Fig. 2. Map showing the locality of stream sample AK-N13-1 and the surrounding geology of the Flatraket area (compiled from Krabbendam et al., 2000; Carswell et al., 2003). 


\subsection{Ulvesund body}

The Ulvesund body is located in the HP-UHP transition zone (Wain, 1997) and is mainly composed of medium- and fine-grained garnetiferous felsic gneiss, which contains relicts of metamorphic (granulite-, eclogite- and amphibolite-facies) assemblages. Ultramafic pods have only minor distribution in comparison to the Flatraket body. Most mafic pods are small with well equilibrated eclogite-facies assemblages (Krabbendam et al., 2000).

The Trollebøelva stream sample (AK-N8-1) was taken near the river mouth (Fig. 3). Additionally some bedrocks were collected from this area for comparison. Sample AK-N9-1 is a granulite taken in outcrop; sample AK-N8-2 is a pebble of eclogitic composition collected from the river bed. The geographic coordinates of all samples are given in Table 1. 


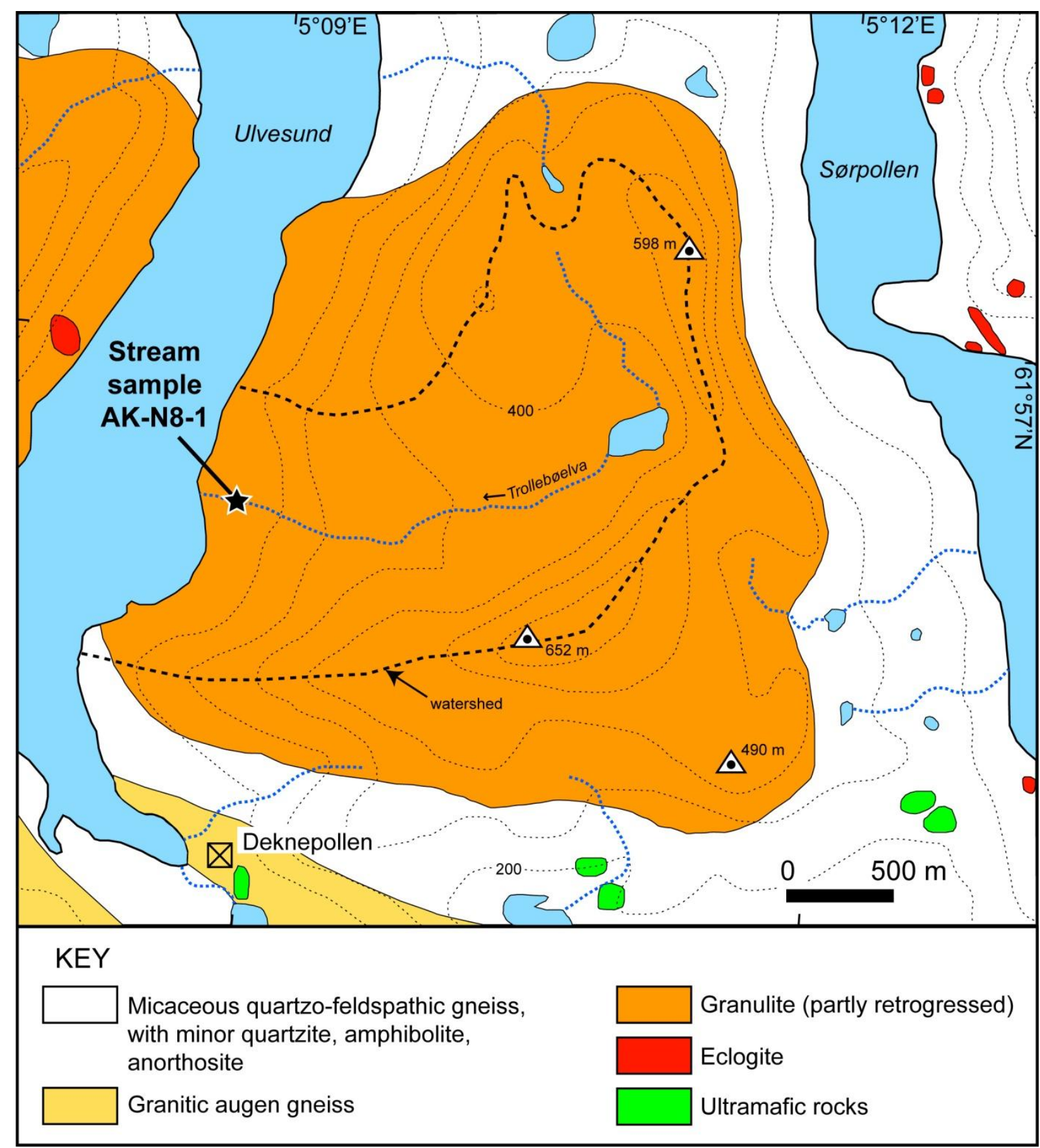

Fig. 3. Map showing the locality of stream sample AK-N8-1 and the surrounding geology of the Ulvesund area (modified from Krabbendam et al., 2000).

\subsection{Runde}

The island of Runde is located within a UHP domain, which is interpreted to be allochthonous relative to the WGR basement (Root et al., 2005; Beyer et al., 2012). The main rock type of the island of Runde is quartzo-feldspathic gneiss. The allochthonous cover units include different types of rock such as quartzites, marbles, calc-silicate gneisses, kyanite schists, augen gneisses, amphibolite and garnet free 
peridotite, as well as eclogites, which makes this area more heterogeneous than the other two catchment areas (Root et al., 2005; Beyer et al., 2012).

The sample (AK-N37) was taken from the beach on the southern side of the island (Fig. 4). Also, two bedrock samples were collected for comparison with the beach sample. Sample AK-N38 is an eclogite and sample AK-N39-1 is a garnetiferous gneiss taken in outcrop. The geographic coordinates of all samples are given in Table 1.

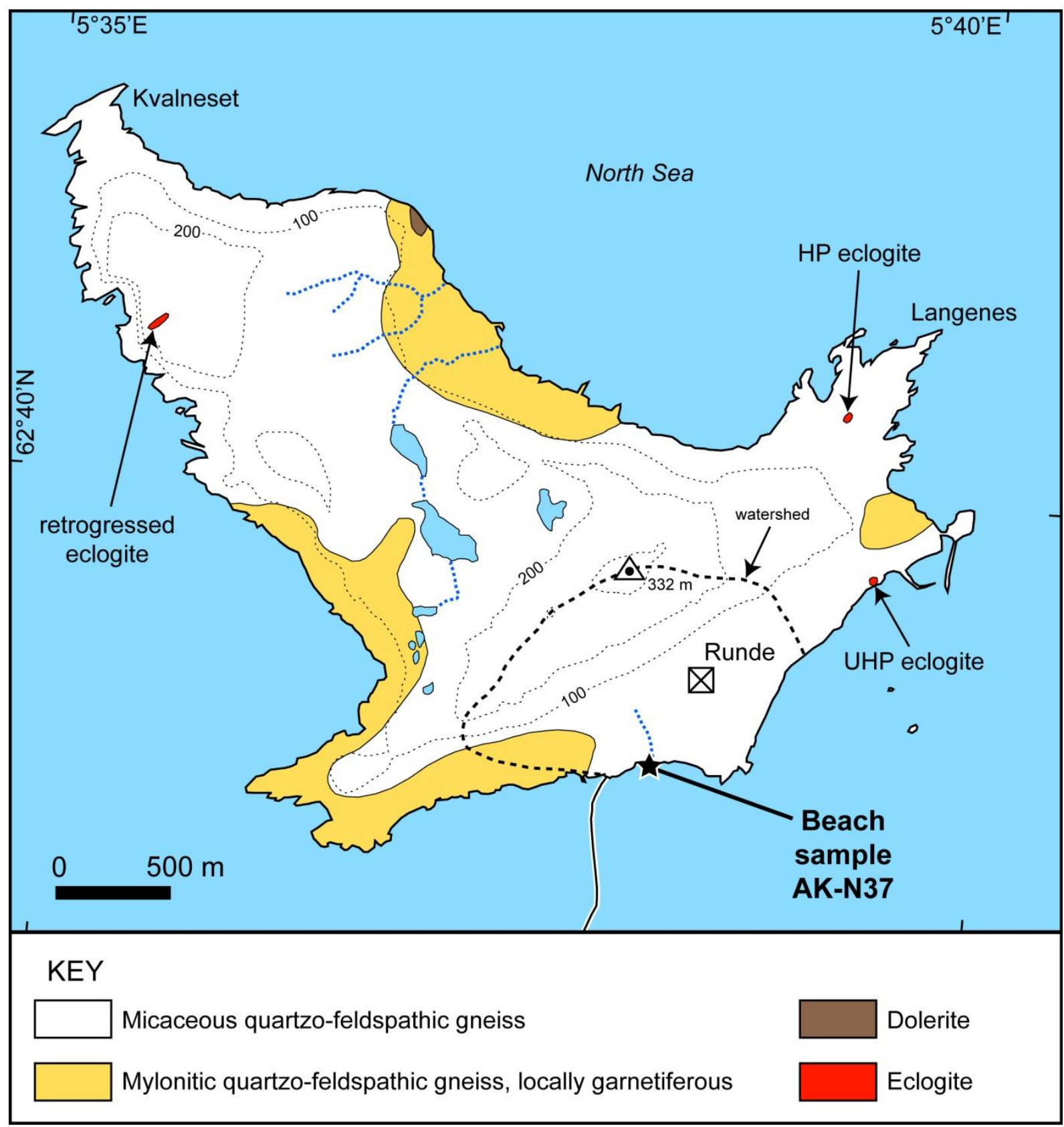

Fig. 4. Map showing the locality of beach sample AK-N37 and the surrounding geology. Modified from a NGU map of Runde island (1:50000) prepared by the NGU map generator (http://geo.ngu.no/kart/berggrunn/). The eclogite localities are also indicated (Root et al., 2005; Spencer et al., 2013; Bradley R. Hacker, personal communication; own field observations). 
Table 1. Sample location data (WGS 84) of all samples (stream sediments and hardrocks).

\begin{tabular}{|l|l|l|l|l|}
\hline Sample & type & Localitiy & Northing & Easting \\
\hline AK-N8-1 & stream & Ulvesund body & $61^{\circ} 56.565^{\prime}$ & $5^{\circ} 08.809^{\prime}$ \\
\hline AK-N8-2 & pebble & Ulvesund body & $61^{\circ} 56.565^{\prime}$ & $5^{\circ} 08.809^{\prime}$ \\
\hline AK-N9-1 & granulite & Ulvesund body & $61^{\circ} 56.257^{\prime}$ & $5^{\circ} 08.565^{\prime}$ \\
\hline AK-N11 & granulite & E of Flatraket & $61^{\circ} 58.703^{\prime}$ & $5^{\circ} 14.716^{\prime}$ \\
\hline AK-N12 & eclogite (UHP) & Flatraket harbour & $61^{\circ} 58.710^{\prime}$ & $5^{\circ} 14.063^{\prime}$ \\
\hline AK-N13-1 & stream & Flatraket & $61^{\circ} 58.554^{\prime}$ & $5^{\circ} 13.845^{\prime}$ \\
\hline AK-N13-2 & pebbles & Flatraket & $61^{\circ} 58.554^{\prime}$ & $5^{\circ} 13.845^{\prime}$ \\
\hline AK-N16-1 & eclogite & Flatraket & $61^{\circ} 57.281^{\prime}$ & $5^{\circ} 12.562^{\prime}$ \\
\hline AK-N37 & beach & Runde & $62^{\circ} 23.341^{\prime}$ & $5^{\circ} 38.252^{\prime}$ \\
\hline AK-N38 & eclogite & Runde & $62^{\circ} 24.212^{\prime}$ & $5^{\circ} 39.230^{\prime}$ \\
\hline AK-N39-1 & garnet gneiss & Runde & $62^{\circ} 24.012^{\prime}$ & $5^{\circ} 39.459^{\prime}$ \\
\hline
\end{tabular}

\section{Methods}

Recent fluviatile deposits near or directly at the river mouth were sampled. In addition, bedrock samples were collected since they represent the source for the detrital material. Bedrocks were taken in outcrop and pebbles were taken directly from the river bed.

Stream sediments were wet-sieved using a sieving machine. After drying, the 63-125 $\mu \mathrm{m}$ size fractions were treated with acetic acid to remove the carbonate component if present. The heavy mineral fractions were separated using sodium metatungstate with a density of $2.85 \mathrm{~g} / \mathrm{mL}$. The heavy mineral residues were mounted on microscope slides (Mange and Maurer, 1992) using Meltmount ${ }^{\mathrm{TM}}$ with a refraction of 1.66 and identified under the polarising microscope, with the relative abundances determined by grain counting. For that, the microscope slide was moved along linear traverses and all grains between two parallel lines were counted (i.e. ribbon counting; Mange and Maurer, 1992). Two-hundred fifty translucent minerals were point counted. Data of all heavy minerals including opaque minerals, micas and unknown are given as supplementary data (see Supplementary Table 1) and in a second table only groups of transparent minerals are given (see Supplementary Table 2).

Garnet selection from the stream sediments was achieved by handpicking under a binocular microscope. We randomly selected garnet grains of all sizes and morphological types and set them in synthetic mounts. From the bedrock samples polished thin sections were prepared. Bedrock and stream samples were analysed with a JEOL JXA $8900 \mathrm{RL}$ electron microprobe (EMP) equipped with five wavelength dispersive spectrometers at the University of Göttingen (Department of 
Geochemistry, Geoscience Center). Before analysis, all samples were coated with carbon to ensure conductivity. Conditions included an accelerating voltage of $15 \mathrm{kV}$ and a beam current of $20 \mathrm{nA}$. The counting times were 15 seconds for $\mathrm{Si}, \mathrm{Mg}, \mathrm{Ca}$, $\mathrm{Fe}$, and $\mathrm{Al}$, and 30 seconds for $\mathrm{Ti}, \mathrm{Cr}$, and $\mathrm{Mn}$. Matrix correction was performed using ZAF corrections. We preferentially analysed garnet rims and cores. Measurement conditions are also given in Table 2. The full database including lithology and metamorphic grade are included in Supplementary Table 3.

Table 2. Operating conditions of the electron microprobe for garnet analyses. Count time on the peak (in s), Bckg time counting time on background position (in s), DL detection limit (in ppm).

\begin{tabular}{|c|c|c|c|c|c|c|c|c|}
\hline Spectrometer & $1 \mathrm{TAP}$ & $1 \mathrm{TAP}$ & 2 TAP & 3 PETJ & 4 PETJ & 4 PETJ & 5 LIFH & $5 \mathrm{LIFH}$ \\
\hline $\begin{array}{l}\text { Element } \\
\text { (Line) }\end{array}$ & Si $(K \alpha)$ & $\mathrm{Al}(\mathrm{K} \alpha)$ & $M g(K \alpha)$ & $\mathrm{Ca}(\mathrm{Ka})$ & $\mathrm{Ti}(\mathrm{K} \alpha)$ & $\operatorname{Cr}(\mathrm{Ka})$ & $M n(K \alpha)$ & $\mathrm{Fe}(\mathrm{K \alpha})$ \\
\hline Count time & 15 & 15 & 15 & 15 & 30 & 30 & 30 & 15 \\
\hline $\begin{array}{l}\text { Bckg time } \\
\text { Standard }\end{array}$ & $\begin{array}{l}5 \\
\text { Garnet, } \\
\text { natural }\end{array}$ & $\begin{array}{l}5 \\
\text { Garnet, } \\
\text { natural }\end{array}$ & $\begin{array}{l}5 \\
\text { MgO, } \\
\text { synthetic }\end{array}$ & $\begin{array}{l}5 \\
\mathrm{CaSiO}_{3} \text {, } \\
\text { natural }\end{array}$ & $\begin{array}{l}15 \\
\mathrm{TiO}_{2}, \\
\text { synthetic }\end{array}$ & $\begin{array}{l}15 \\
\mathrm{Cr}_{2} \mathrm{O}_{3}, \\
\text { synthetic }\end{array}$ & $\begin{array}{l}15 \\
\text { Rhodonite, } \\
\text { natural }\end{array}$ & $\begin{array}{l}5 \\
\mathrm{Fe}_{2} \mathrm{O}_{3}, \\
\text { synthetic }\end{array}$ \\
\hline $\mathrm{DL}$ & 160 & 138 & 104 & 138 & 113 & 135 & 117 & 216 \\
\hline
\end{tabular}

\section{Results}

\subsection{Heavy mineral analysis}

Opaque minerals and micas are not considered in the diagram to get the true information of the total concentration of transparent heavy minerals.

Flatraket. The dominant heavy minerals are green calcic amphibole which represents $36 \%$ and epidote-group minerals (epidote, zoisite) which represent $39 \%$ of the heavy mineral spectrum. Here, zoisite is the most dominant mineral. Garnet, pyroxene, apatite, and stable minerals (zircon, tourmaline, and rutile) occur in minor percentages. Olivine, titanite and kyanite occur only in low percentages and are therefore grouped as 'others' (Fig. 5).

Ulvesund body. The dominant heavy mineral is garnet, which represents $73 \%$ of the heavy mineral spectrum. Green calcic amphibole, epidote-group and apatite occur in relatively high percentages. Pyroxene and stable minerals (zircon, tourmaline, and rutile) occur only in minor percentages. Kyanite occurs only in very low percentages and is therefore grouped as 'others' (Fig. 5).

Runde. The dominant heavy minerals are garnet, which represents $30 \%$, and green calcic amphibole, which represents $45 \%$ of the heavy mineral spectrum. Epidote 
group minerals, pyroxene, apatite, and stable minerals (zircon, tourmaline, and rutile) occur in minor percentages. Olivine, titanite and kyanite occur only in low percentages and are therefore grouped as 'others' (Fig. 5). Opaque minerals and micas are not considered in the diagram to get the true information of the total concentration of transparent heavy minerals (HM).

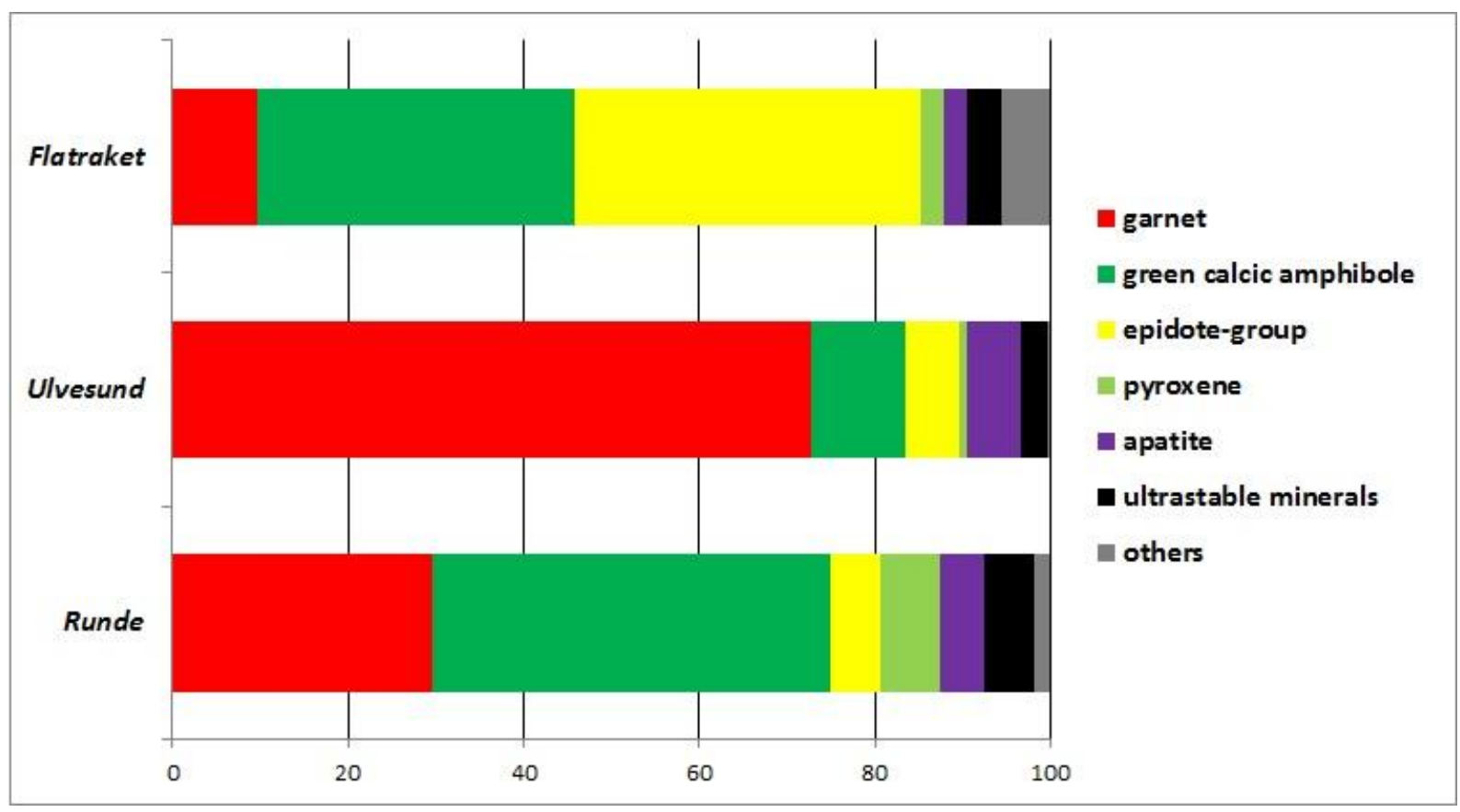

Fig. 5. Heavy mineral assemblages of sediment samples from the three catchment areas. Epidotegroup: epidote, zoisite; ultrastable minerals: zircon, rutile, tourmaline; others: olivine, titanite, kyanite.

\subsection{Garnet geochemistry}

The composition of garnets is illustrated in the ternary classification diagram of Mange and Morton (2007) using almandine + spessartine, pyrope, and grossular as poles, and the discrimination fields $\mathrm{A}, \mathrm{B}, \mathrm{Bi}, \mathrm{Ci}, \mathrm{Cii}$, and $\mathrm{D}$ (Fig. 6). This diagram has widely been applied in a number of garnet provenance studies (e.g., Whitham et al., 2004; Morton et al., 2005; Mange and Morton, 2007; Meinhold et al., 2010; Morton et al., 2011).

\section{Flatraket}

Garnets of sample AK-N13-2a overlap three compositional fields (A, Ci, and Cii) but most of them are type A garnets (Fig. 6a). Most of the garnets from sample AK-N12 are type Cii garnets, some of them also plot in field Ci. Garnets of samples AK-N132b, AK-N13-2d, and AK-N11 plot in field Ci. Garnets of sample N-16 plot in field Ci and field B. Garnets of sample AK-N13-2c are type B garnets. Most of the garnets 
from the stream sediment are type Ci garnets (83\%). Some of the garnets also plot in fields $\mathrm{A}(9 \%), \mathrm{B}(5 \%), \mathrm{Bi}(2 \%)$, and $\mathrm{Cii}(1 \%)$.

\section{Ulvesund body}

Garnets of samples AK-N8-2 and AK-N9-1 are both type Ci garnets (Fig. 6b). Nearly all of the garnets from the stream sediment are type Ci garnets (95\%). Few garnets also plot in fields $\mathrm{A}(1 \%), \mathrm{Bi}(1 \%)$, and $\mathrm{Bi}(3 \%)$.

\section{Runde}

Garnets of sample AK-N39-1 plot in fields Bi and A (Fig. 6c). Garnets of sample AKN38 plot in field Ci. Nearly all of the garnets from the stream sediment are type Ci garnets (85\%). Few garnets also plot in fields $A(8 \%)$ and $B(7 \%)$.
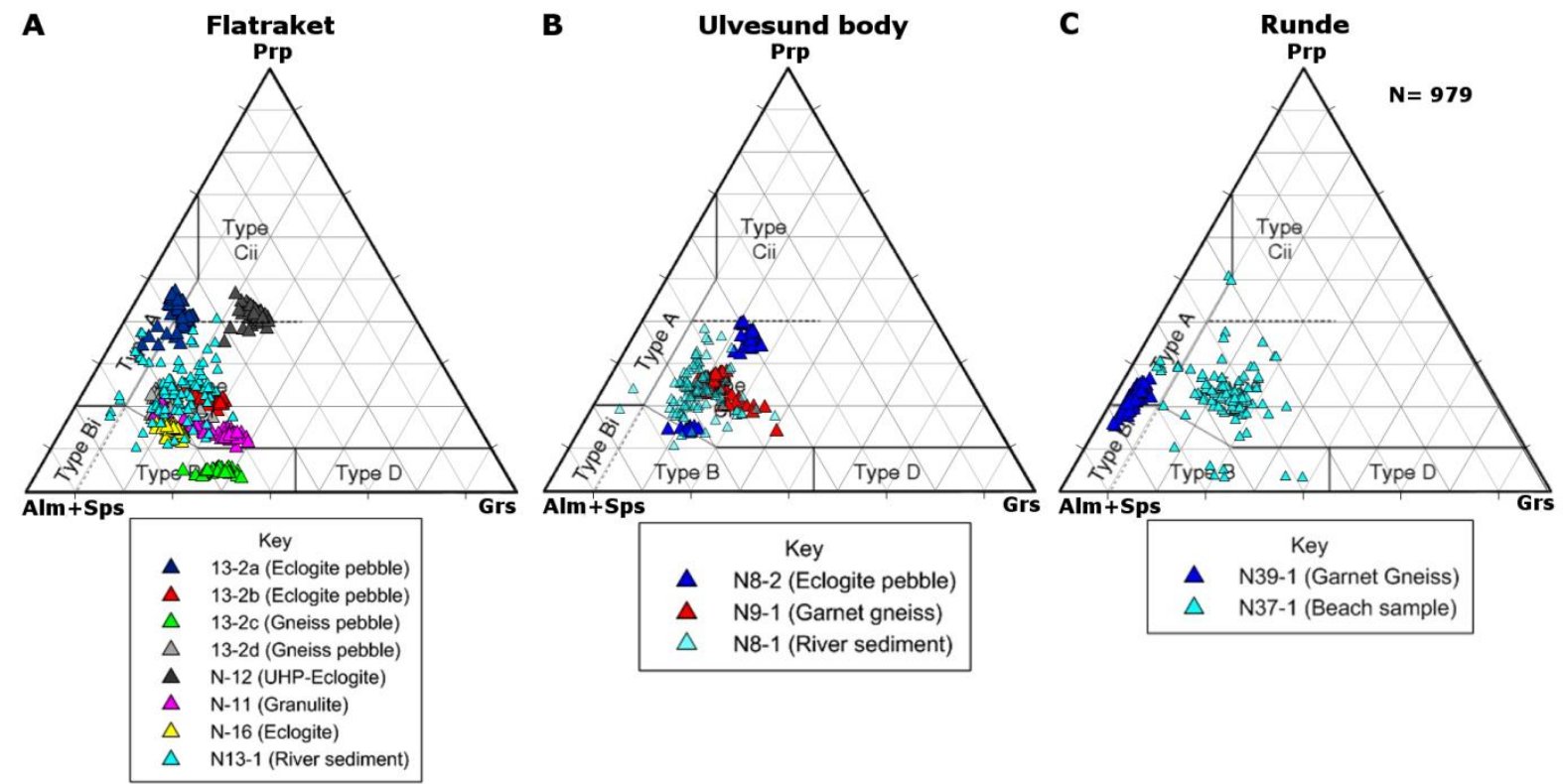

Fig. 6. Composition of garnets in the ternary classification diagram of Mange and Morton (2007) with almandine+spessartine, grossular and pyrope as poles. A) Composition of detrital garnets from the stream sediment and from the bedrock samples from Flatraket. B) Composition of detrital garnets from the stream sediment and from the bedrock samples from the Ulvesund body. C) Composition of detrital garnets from the stream sediment and from the bedrock samples from the island of Runde. A mainly from high-grade granulite-facies metasedimentary rocks or charnockites and intermediate felsic igneous rocks, $\mathrm{B}$ - amphibolite-facies metasedimentary rocks, $\mathrm{Bi}$ - intermediate to felsic igneous rocks, $\mathrm{Ci}$ - mainly from high-grade mafic rocks, Cii - ultramafics with high $\mathrm{Mg}$ (pyroxenites and peridotites), D - metasomatic rocks, very low-grade metamafic rocks and ultrahigh-temperature metamorphosed calc-silicate granulites. 


\section{Discussion}

Overall, the heavy mineral association and garnet geochemical data reflect the geological setting of the study area, but some garnets measured in the bedrocks are lacking in the sediments. Detrital heavy minerals commonly reflect very well the situation in the source area. Geochemical data of heavy minerals often show a wider distribution in the sediments than the data of heavy minerals measured in the bedrocks, because it is not always possible to sample all outcrop rocks due to difficult conditions in the source area. Our results reveal that this is not always the case.

The detrital garnets from all three study areas in SW Norway reflect high-pressure conditions in the source area since almost all the garnets plot in field $\mathrm{Ci}$, the field for higher grade metamorphic garnets. A few detrital garnets show UHP conditions in the source area.

The heavy mineral assemblages from Flatraket, Ulvesund, and Runde are comparable with garnet, green calcic amphibole and epidote-group minerals being the dominant heavy minerals, which reflect greenschist and higher grade metamorphism in the source area. The dominant heavy minerals in the stream sample from Flatraket are green calcic amphibole and epidote-group minerals (almost $70 \%$ of the HM spectrum), which reflect the amphibolite-facies assemblages of the surrounding gneisses (Krabbendam et al., 2000) (Supplementary Table 4). Garnet and pyroxene can be linked to the granulite- and eclogite-facies gneisses and mafic layers and pods (Supplementary Table 4), which are widespread distributed within the gneisses. The geochemical data show that the eclogites and granulites are the main source of the detrital garnets. The garnets of the amphibolite-facies gneisses are not well preserved in the stream sediment, probably because the gneisses only locally contain garnet grains. None of the garnets of the stream sediment sample from Flatraket overlap with the garnets of the gneiss pebble (sample AK-N13-2c). This possibly results from the coarser grain-sizes of garnets in this sample. The garnet grains of sample AK-N13-2c are often coarser than $500 \mu \mathrm{m}$ (Supplementary Table 5).

The dominant heavy mineral of the sample from the Ulvesund body is garnet, which makes up more than $60 \%$ of the entire heavy mineral spectra. Most of the Ulvesund body comprises medium- and fine-grained garnetiferous felsic gneiss with dominantly amphibolite-facies assemblages, which represent remnants of granulite-facies assemblages. The geochemical data of the detrital garnets reflect higher grade 
metamorphic conditions, because almost all of the detrital garnets plot in field $\mathrm{Ci}$. In many samples a slight decrease of $\mathrm{MgO}$ from core to rim is visible, which shows that the garnets are affected by retrogression, but this is only marginally significant. The results point to granulite-facies metamorphism in the source area. Also, garnets measured in the bedrocks show higher grade metamorphic conditions. In summary, the heavy mineral spectrum and the geochemical data from the stream sample of the Ulvesund body show a high input from rocks of granulite- and eclogite-facies assemblages.

The heavy mineral spectrum of Runde is dominated by garnet and green calcic amphibole. The allochthonous cover units experienced high-pressure amphibolitefacies and a low-pressure granulite facies overprint (Root et al., 2005). The geochemical data of the detrital garnets show that the garnets are derived from highgrade metamorphic rocks, since they overlap with garnets measured in the eclogite. Some of the detrital garnets are derived from lower grade metamorphic rocks such as amphibolite-facies metasedimentary rocks and can probably be linked to the allochthonous cover units. There are also two type Cii garnets, which point to UHP conditions in the source area. This fits with the results from Root et al. (2004) who identified relict coesite (a UHP indicator mineral) in the core of garnets from an eclogite collected from Runde. None of the garnets of the stream sediment sample from Runde overlap with the garnets of the garnet gneiss (sample AK-N39-1). This possibly results from the coarser grain-sizes of garnets in this sample (Supplementary Table S5). The heavy mineral assemblages are similar in Flatraket, Ulvesund and Runde, and only vary in proportions, probably depending on the distribution of their source rocks in the catchment area. The garnet composition of all samples shows a high degree of overlap since most of the garnets plot in field Ci with minor type $\mathrm{Cii}$, type $\mathrm{A}$, type $\mathrm{B}$, and type Bi garnets. UHP pressure conditions are only evident in the stream sample of Flatraket and the beach sample of Runde. From both locations, eclogites containing relict coesite inclusions in garnets are known, which points to UHP conditions in each of these areas. UHP conditions are not evident in the garnets of rocks from the Ulvesund body. This is consistent with the lack of evidence for UHP eclogites in this area. Because the UHP eclogites of Flatraket and Runde are rather exceptional, garnets from these rocks, if any, only rarely occur in the sediment. Nonetheless, very few detrital garnets point to these UHP rocks. 
The Trollebøelva stream drains the granulite of the Ulvesund body (Fig. 3), which explains the high input of garnet grains, which in turn reflects the high-pressure conditions in this area. Type B garnets are most evident in the sample from Runde. This is not surprising because garnet is common in the metasedimentary units of the allochthonous cover units in contrast to the amphibolite-facies gneisses of the basement. Therefore, the content of lower grade metamorphic garnet is higher on the island of Runde in contrast to the other two study areas. There, the input of lower grade metamorphic garnet may be diluted by the high input of higher grade metamorphic garnet, because the content of garnet is higher in the rocks with granulite- and eclogite-facies assemblages. Also possible is the grain-size inheritance from source to sediment, as some samples of the amphibolite-facies gneisses have large garnet grains (>125 $\mu \mathrm{m}$ in size) and are therefore not evident in the analysed grain-size fraction from 63-125 $\mu \mathrm{m}$ (Supplementary Table 5).

\section{Conclusions}

The heavy mineral and garnet geochemical data very well reflect the geological situation in all three study areas. The dominant rock type in the areas is layered micaceous quartzo-feldspathic gneiss. The gneisses show amphibolite-facies assemblages of green calcic amphibole \pm epidote-group and \pm garnet (Krabbendam et al., 2000), which is evident in the heavy mineral spectra. In the three study areas, most of the garnets are derived from higher grade metamorphic rocks such as eclogites and granulites, because these rocks have a high content of garnet in contrast to the amphibolite-facies gneisses, which mainly contain green calcic amphibole, epidote-group minerals and only locally garnets. This is most seen in the sample from the Ulvesund body where the stream drains the granulite, which carries huge amounts of garnet grains. However, some detrital garnets cannot be linked to the garnets analysed in the bedrocks, especially garnets derived from amphibolitefacies gneisses. On one hand, this may be due to dilution by strong influx of garnets from higher grade metamorphic rocks, but, on the other hand, this may result from the original coarser grain-size of garnets in the host rocks. Even though UHP eclogites are only very rarely exposed in the study area, they are evident in the detrital garnets of Flatraket and Runde. With only little effort (one sample per stream) it is possible to get a relatively clear picture about the study area. However, to maximise the amount of provenance information, a larger number of samples from a 
variety of locations should be used, as well as a wide grain-size range (see Krippner et al., 2015). Nevertheless, our results underline the applicability of heavy minerals and the power of garnet geochemistry in sedimentary provenance analysis

\section{Acknowledgments}

The PhD scholarship of AK is financed by CASP. Fieldwork and analytical work was financed by the German Research Foundation (DFG grant EY 23/20-1). We thank Andreas Kronz for his help with EMP analyses.

\section{References}

Andersen, T.B., Jamtveit, B., Dewey, J.F. \& Swensson, E. 1991: Subduction and eduction of continental crust: major mechanism during continent-continent collision and orogenic collapse, a model based on the south Norwegian Caledonides. Terra Nova 3, 303-310.

Andò, S. 2007: Heavy minerals: provenance, hydraulic sorting, weathering. Unpublished PhD Thesis, University of Milano-Bicocca, $210 \mathrm{pp}$.

Andò, S., Morton, A.C. \& Garzanti, E. 2014: Metamorphic grade of source rocks revealed by chemical fingerprints of detrital amphibole and garnet. In Scott, R.A., Smyth, H.R., Morton, A.C. \& Richardson, N. (eds.): Sediment Provenance Studies in Hydrocarbon Exploration and Production. Geological Society of London, Special Publications 386, 351-371.

Beyer, E.E., Brueckner, H.K., Griffin, W.L. \& O'Reilly, S.Y. 2012: Laurentian Provenance of Archean Mantle Fragments in the Proterozoic Baltic Crust of the Norwegian Caledonides. Journal of Petrology 53, 1357-1383.

Brueckner, H.K. \& van Roermund, H.L.M. 2004: Dunk tectonics: a multiple subduction/eduction model for the evolution of the Scandinavian Caledonides. Tectonics 23, TC2004, doi:10.1029/2003TC001502.

Brueckner, H.K. 1998: Sinking intrusion model for the emplacement of garnet-bearing peridotites into continent collision orogens. Geology 26, 631-634.

Bryhni, I. \& Andréasson, P.G. 1985. Metamorphism in the Scandinavian Caledonides. In Gee, D.G. \& Sturt, B.A. (eds.): The Caledonide orogen Scandinavia and related areas. John Wiley \& Sons, Chichester, 763-781. 
Carswell, D.A., Brueckner, H.K., Cuthbert, S.J., Mehta, K. \& O'Brien, P.J. 2003: The timing of stabilisation and the exhumation rate for ultra-high pressure rocks in the Western Gneiss Region of Norway. Journal of Metamorphic Geology 21, 601612.

Carswell, D.A. \& Cuthbert, S.J. 2003: Review of the mineralogical and microstructural evolution of ultra-high pressure eclogites in the Western Gneiss Region of Norway. In Carswell, D.A., Cuthbert, S.J., Krabbendam, M., Medaris, L.G. \& Brueckner, H.K. (eds.): Guidebook to the field exkursions in the Nordfjord Stadtlandet - Almklovdalen area. Norges geologiske undersøkelse Report, 3-47.

Deer, W.A., Howie, R.A. \& Zussman, J. 1992: An introduction to rock-forming minerals. Longman Group Ltd, Harlow, UK, 712 pp.

Garzanti, E., Andò, S. \& Vezzoli, G. 2008: Settling-equivalence of detrital minerals and grain-size dependence of sediment composition. Earth and Planetary Science Letters 273, 138-151.

Garzanti, E., Andò, S. \& Vezzoli, G. 2009: Grain-size dependence of sediment composition and environmental bias in provenance studies. Earth and Planetary Science Letters 277, 422-432.

Garzanti, E., Resentini, A. \& Vezzoli, G. 2010: Detrital fingerprints of fossil continental-subduction zones (Axial Belt Provenance, European Alps). Journal of Geology 118, 341-362.

Gebauer, D., Lappin, M.A., Grunenfelder, M. \& Wyttenbach, A. 1985: The age and origin of some Norwegian eclogites: a U-Pb zircon and REE study. Chemical Geology 52, 22-47.

Griffin, W.L. \& Brueckner, H.K. 1980: Caledonian Sm-Nd ages and a crustal origin of Norwegian eclogites. Nature 285, 319-321.

Griffin, W.L. \& Brueckner, H.K., 1985: REE, Rb-Sr and Sm-Nd studies of Norwegian eclogites. Chemical Geology 52, 249-271.

Griffin, W.L., Austrheim, H., Brastad, K., Bryhni, I., Krill, A.G., Krogh, E.J., Mørk, M.B.E., Qvale, H. \& Torudbakken, B. 1985: High-pressure metamorphism in the Scandinavien Caledonides. In Gee, D.G. \& Sturt, B.A. (eds.): The Caledonide orogen - Scandinavia and related areas. John Wiley \& Sons, Chichester, 783-801.

Hacker, B.R., Andersen, T.B., Johnston, S., Kylander-Clark, A.R.C., Peterman, E.M., Walsh, E.O. \& Young, D. 2010: High-temperature deformation during 
continental-margin subduction \& exhumation: The ultrahigh-pressure Western Gneiss Region of Norway. Tectonophysics 480, 149-171.

Krabbendam, M. \& Wain, A. 1997: Late-Caledonian structures, differential regression and structural position of (ultra)high-pressure rocks in the Nordfjord-Stradlandet area, Western Gneiss Region. Norges Geologiske Undersøkelse 432, 127-139.

Krabbendam, M., Wain, A. \& Andersen, T.B. 2000: Pre-Caledonian granulite and gabbro enclaves in the Western Gneiss Region, Norway: indications of incomplete transition at high pressure. Geological Magazine 137, 235-255.

Kylander-Clark, A.R.C., Hacker, B.R. \& Mattinson, J.M. 2008: Slow exhumation of UHP terranes: Titanite and rutile ages of the Western Gneiss Region, Norway. Earth and Planetary Science Letters 272, 531-540.

Krippner, A., Meinhold, G., Morton, A.C. \& von Eynatten, H. 2014: Evaluation of garnet discrimination diagrams using geochemical data derived from various host rocks. Sedimentary Geology 306, 36-52.

Krippner, A., Meinhold, G., Morton, A.C., Russell, E. \& von Eynatten, H. 2015: Grainsize dependence of garnet composition revealed by provenance signatures of modern stream sediments from the western Hohe Tauern (Austria). Sedimentary Geology 321, 25-38.

Mange, M.A. \& Maurer, H.F.W. 1992: Heavy minerals in color. Chapman and Hall, London, $147 \mathrm{pp}$.

Mange, M.A. \& Morton, A.C. 2007: Geochemistry of heavy minerals. In Mange, M.A. \& Wright, D.T. (eds.): Heavy minerals in use. Elsevier, Amsterdam, Developments in Sedimentology 58, 345-391.

Meinhold, G., Reischmann, T., Kostopoulos, D., Frei, D. \& Larionov, A.N. 2010: Mineral chemical and geochronological constraints on the age and provenance of the eastern Circum-Rhodope Belt low-grade metasedimentary rocks, NE Greece. Sedimentary Geology 229, 207-223.

Miyashiro, A. 1953: Ca-poor garnet in relation to metamorphism. Geochimica et Cosmochimica Acta 4, 179-208.

Morton, A.C. \& Hallsworth, C.R. 1999: Processes controlling the composition of heavy mineral assemblages in sandstones. Sedimentary Geology 124, 3-29.

Morton, A.C., Whitham, A.G. \& Fanning, C.M. 2005: Provenance of Late Cretaceous to Paleocene submarine fan sandstones in the Norwegian Sea: integration of 
heavy mineral, mineral chemical and zircon age data. Sedimentary Geology 182, 3-28.

Morton, A.C., Meinhold, G., Howard, J.P., Phillips, R.J., Strogen, D., Abutarruma, Y., Elgadry, M., Thusu, B. \& Whitham, A.G. 2011: A heavy mineral study of sandstones from the eastern margin of the Murzuq Basin, Libya: constraints on provenance and stratigraphic correlation. Journal of African Earth Sciences 61, 308-330.

Mørk, M.B.E. \& Mearns, E.W. 1985: Sm-Nd isotopic systematics of a gabbro-eclogite transition. Lithos 19, 255-267.

Nandi, K. 1967: Garnets as indices of progressive regional metamorphism. Mineralogical Magazine 36, 89-93.

Roberts, D.C. \& Gee, D.G. 1985: An introduction to the structure of the Scandinavian Caledonides. In Gee, D.G. \& Sturt, B.A. (eds.): The Caledonide orogen Scandinavia and related areas. John Wiley \& Sons, Chichester, 55-68.

Root, D.B., Hacker, B.R., Mattinson J.M. \& Wooden J.L. 2004: Zircon geochronology and ca. $400 \mathrm{Ma}$ exhumation of Norwegian ultrahigh-pressure rocks: an ion microprobe and chemical abrasion study. Earth and Planetary Science Letters 228, 325-341.

Root, D.B., Hacker, B.R., Gans, P.B., Duccea, M.N., Eide, E.A. \& Mosenfelder, L. 2005: Discrete ultrahigh-pressure domains in the Western Gneiss Region, Norway: Implications for formation and exhumation. Journal of Metamorphic Geology 23, 45-61.

Schuiling, R.D., de Meijer, R.J., Riezebos, H.J. \& Scholten, M.J. 1985: Grain-size distribution of different minerals in a sediment as a function of their specific density. Geologie en Mijnbouw 64, 199-203.

Spencer, K.J., Hacker, B.R., Kylander-Clark, A.R.C., Andersen, T.B., Cottle, J.M. \& Stearns, M.A. 2013: Campaign-style titanite U-Pb dating by laser-ablation ICP: Implications for crustal flow, phase transformations and titanite closure. Chemical Geology 341, 84-101.

Spengler, D., Brueckner, H.K., van Roermund, H.L.M., Drury, M.R. \& Mason, P.R.D. 2009: Long-lived, cold burial of Baltica towards $200 \mathrm{~km}$ depth. Earth and Planetary Science Letters 281, 27-35. 
Terry, M.P. \& Robinson, P. 2004: Geometry of eclogite-facies structural features: Implications for production and exhumation of ultrahigh-pressure and highpressure rocks, Western Gneiss Region, Norway. Tectonics 23, 1-23.

Tucker, R.D., Krogh, T.E. \& Råheim, A. 1990: Proterozoic evolution and ageprovince boundaries in the central part of the Western Gneiss Region, Norway; results of U-Pb dating of accessory minerals from Trondheimsfjord to Geieranger. In Gower, C.F., Rivers, T. \& Ryan, B. (eds.): Mid-Proterozoic Laurentia-Baltica. Geological Association of Canada, Special Paper 38, 149-73.

von Eynatten, H., Tolosana-Delgado, R. \& Karius, V. 2012: Sediment generation in modern glacial settings: Grain-size and source-rock control on sediment composition. Sedimentary Geology 208, 80-92.

Wain, A. 1997: New evidence for coesite in eclogite and gneisses: defining an ultrahigh-pressure province in the Western Gneiss region of Norway. Geology 25, 927-930.

Wain, A.L., Waters, D.J. \& Austrheim, H. 2001: Metastability of granulites and processes of eclogitisation in the UHP region of western Norway. Journal of Metamorphic Geology 19, 607-623.

Wang, Q., Xia, Q.-K., O'Reilly, Y., Griffin, W.L., Beyer, E.E. \& Brueckner, H.K. 2013: Pressure- and stress-induced fabric transition in olivine from peridotites in the Western Gneiss Region (Norway): implications for mantle seismic anisotropy. Journal of Metamorphic Geology 31, 93-111.

Whitham, A.G., Morton, A.C. \& Fanning, C.M. 2004: Insights into CretaceousPalaeogene sediment transport paths and basin evolution in the North Atlantic from a heavy mineral study of sandstones from southern East Greenland. Petroleum Geoscience 10, 61-72. 


\section{A step-wise classification scheme of garnets for sedimentary provenance analysis: An Approach}

\section{Introduction}

The composition of garnets has been discussed in several publications (e.g., Mange and Morton 2007; Aubrecht et al., 2009). In these publications garnet is mainly classified from different rock types in binary and ternary diagrams using major elements or endmembers of garnets as poles. Commonly the major elements $\mathrm{MgO}$, $\mathrm{MnO}, \mathrm{FeO}$, and $\mathrm{CaO}$ are used to discriminate garnets from different rock types, because generally these elements show the highest variability (e.g., Wright 1938; Krippner et al., 2014 and references therein). Differences in composition have several reasons as described in Chapter II. A clear distinction of garnets from different host rocks is not possible, because garnets show much overlap as also described in Chapter II. The aim is to establish a new classification, which allows the allocation of detrital garnets to a specific host rock with the highest probability. Before it is possible to assign a detrital garnet to a specific rock type with the highest probability, it is needed that we test the potential of discriminating garnets from which the host rock is known. In this Chapter we have a look which elements are most useful to discriminate between the several garnet-bearing groups and present first ideas about the compilation of our garnet data and a step-wise classification of garnets. For this we use the data from our compiled database (Appendix A).

\section{Database compilation}

In a first step, we divide the garnets of the database in specific groups, here described as group A, B, C, D, E1, E2, E3, E4, and F. Group A comprises garnets from eclogites, B from amphibolites, C from granulites, D from ultramafic rocks such as peridotites, groups E1, E2, E3, E4 from magmatic rocks and $F$ from greenschistfacies metasedimentary rocks (Appendix A). Based on studies some groups of garnets show a high degree of overlap which makes discrimination based on major 
elements difficult or even impossible. These are mainly garnets from magmatic rocks, which show high overlap with garnets from metamorphic rocks. The only group of garnets which shows a characteristic signature is group E1 (e.g., Wright et al., 1938, Krippner et al., 2014 and references therein), those garnets from felsic plutonic rocks (Appendix A). Discrimination of group $F$ and group $B$ garnets is also not possible as they show a high degree of overlap. Based on these findings five groups have been crystallised for classifying garnets. These are groups A, B, C, D, and E1. Due to the fact that garnets are not very common or only rarely found in rocks of groups E2, E3, E4, these groups can be disregarded and can be excluded from the analysis. Group B and F may be summarised as "Barrovian type" garnets (group B).

\section{Methodological approach for discriminating groups of garnets}

The discrimination of the groups is progressive and is according to the pattern as shown in Figure 1. In a first step, we discriminate group $D$ from the rest of the groups ( $A, B, C$, and $E 1$ = summarised as group all), because garnets of group $D$ generally have higher $\mathrm{Cr}_{2} \mathrm{O}_{3}$ contents than garnets from the other groups, which commonly have no or very less $\mathrm{Cr}_{2} \mathrm{O}_{3}$ contents and can be therefore easily identified. The remaining groups are group $A, B, C$, and $E 1$. In a second step, we discriminate garnets of group $\mathrm{E} 1$ from group $\mathrm{A}, \mathrm{B}$, and $\mathrm{C}=$ summarised as group metamorph). Group E1 commonly has a higher Mn/Fe ratio than the other garnets and can be identified with a relatively high probability. Discrimination of groups $A, B$, and $C$ is even more challenging, because these garnets commonly show high overlap. Therefore, a strict separation is not possible, but in this model we want to make an attempt to assign the garnet grain to its specific group with a certain probability. 


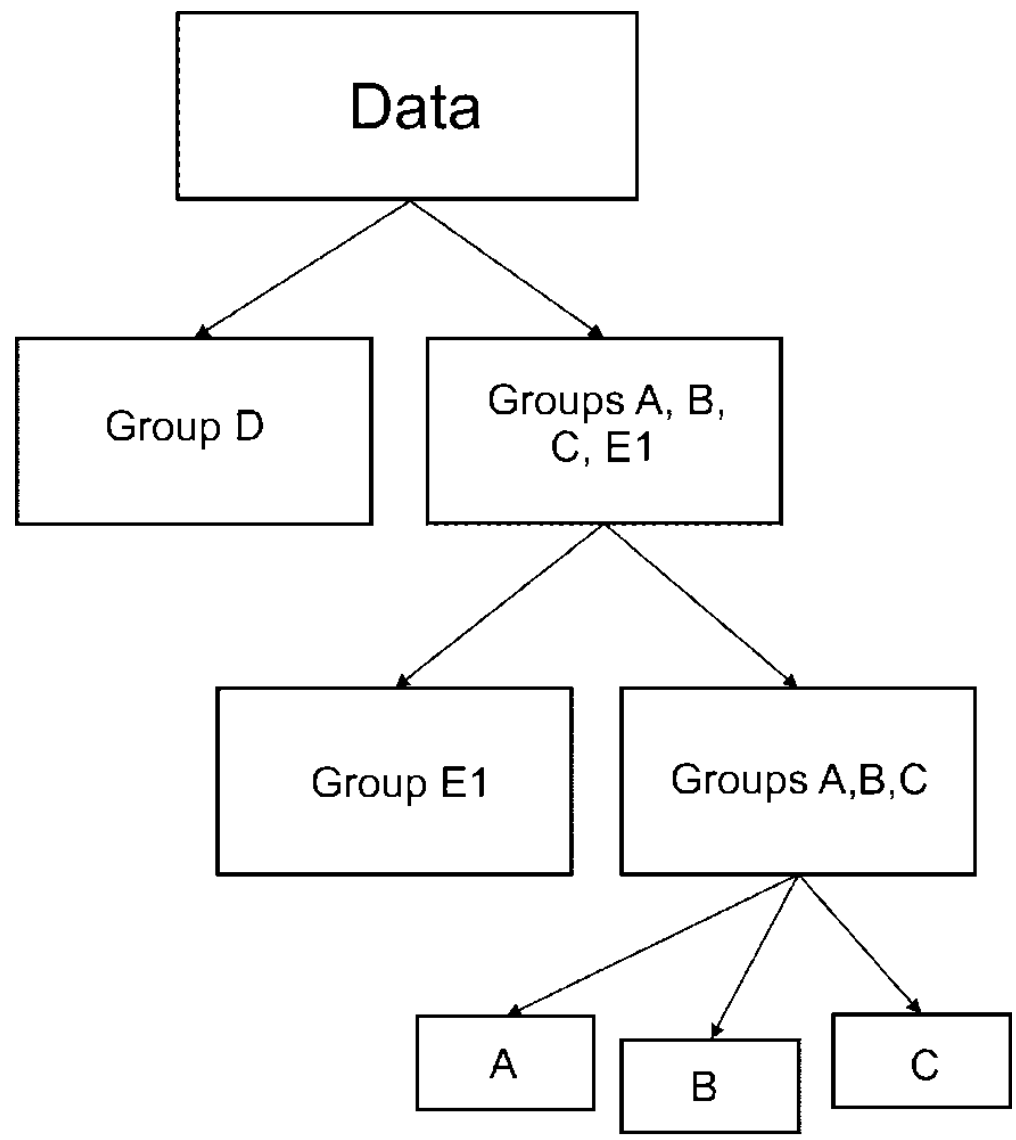

Fig.1. Classification tree for discriminating garnets of groups D, E1, A, B, and C.

\section{Multivariate statistical approach}

Compositional data are proportions of some whole. That means that their relative portions summing up to 1 or 100 \% (van den Boogaart and Tolosana-Delegado, 2013). The dataset provided in this paper comprises compositional data; the portions of the major elements in the garnet. Compositions are multivariate by nature and there are several techniques for analysing the data (van den Boogaart and TolosanaDelegado, 2013). In this study, we analyse our data by using discriminant analysis in order to gain information about compositional variations of the specific garnet groups and to determine which variables are important to discriminate between groups. Additive log-ratio transform (alr) was conducted in $\mathrm{R}$ for major elements. The alr logratio transform is calculated as:

$$
\operatorname{alr}(x)=y=\left[\ln \frac{x_{1}}{x_{D}} ; \ldots \ln \frac{x_{D-1}}{x_{D}}\right]
$$




\section{Discrimination of garnets from ultramafic rocks (group $D$ ) from}

garnets derived from metamorphic (group $A, B, C$ ) and magmatic rocks (E1)

For discrimination of group $D$ from groups $A, B, C$, and $E 1$ (group all) the major elements $\mathrm{SiO}_{2}, \mathrm{Al}_{2} \mathrm{O}_{3}, \mathrm{MgO}, \mathrm{FeO}, \mathrm{MnO}, \mathrm{CaO}$, and $\mathrm{Cr}_{2} \mathrm{O}_{3}$ are used. $\mathrm{Cr}_{2} \mathrm{O}_{3}$ mainly consists of zero values in most of the groups, because the amount is below the detection limit. Here, we assume a detection limit of $200 \mathrm{pm}$ for $\mathrm{Cr}_{2} \mathrm{O}_{3}$. This means that every garnet grain is assigned to one of the two groups: "True" = yes (above detection limit) or "False" = no (below detection limit). The result demonstrates that a garnet with a $\mathrm{Cr}_{2} \mathrm{O}_{3}$ content of $>200 \mathrm{ppm}$ most probably belongs to group $\mathrm{D}$. If the $\mathrm{Cr}_{2} \mathrm{O}_{3}$ content is $>200 \mathrm{ppm}$ the garnets can be either assigned to group $\mathrm{D}$ or group all (Fig. 2). The result also shows that there are only very few garnet grains in group all with a $\mathrm{Cr}_{2} \mathrm{O}_{3}$ content of $>200 \mathrm{ppm}$ (Fig. 2). Therefore the content of $\mathrm{Cr}_{2} \mathrm{O}_{3}$ is very important to discriminate mantle-derived garnets from other metamorphic or magmatic garnets (see also Grütter et al., 2004).

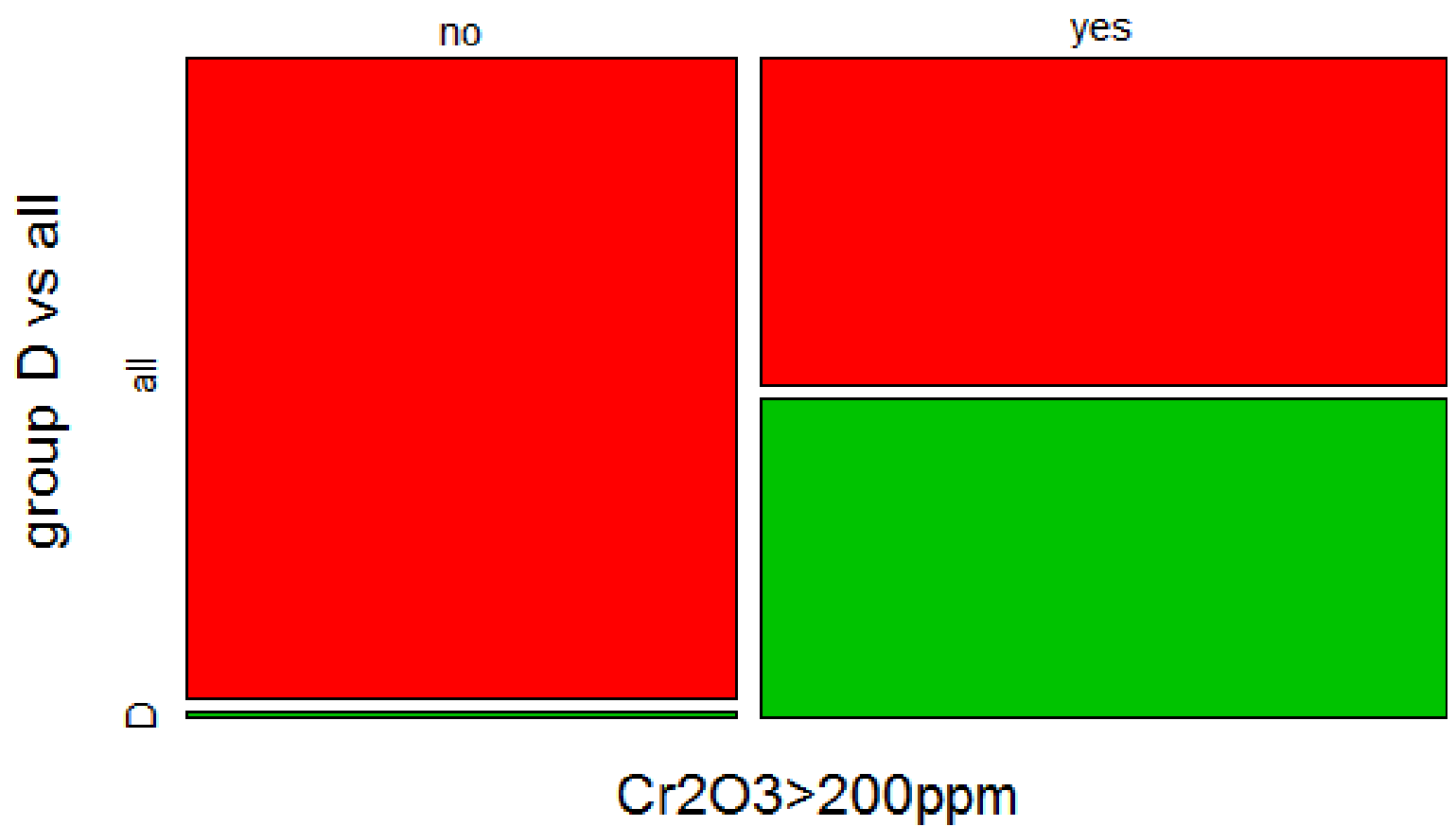

Fig. 2. Mosaicplot of $\mathrm{Cr}_{2} \mathrm{O}_{3}$ content $\left(\mathrm{Cr}_{2} \mathrm{O}_{3}>200\right.$ ppm or $\left.\mathrm{Cr}_{2} \mathrm{O}_{3}<200 \mathrm{ppm}\right)$ for garnets of groups $\mathrm{D}$ and all. The detection limit amounts 200 ppm. no: $\mathrm{Cr}_{2} \mathrm{O}_{3}$ content is below detection limit of 200 ppm; yes: $\mathrm{Cr}_{2} \mathrm{O}_{3}$ content is above detection limit.

A boxplot of the individual variables helps to analyse the variations and agreements of the used major elements in the garnets within the groups. It is useful for the selection of elements which are helpful for discrimination between the different 
groups. The elements with the greatest variation between the groups should be selected for discrimination. For example $\mathrm{Al}_{2} \mathrm{O}_{3}$ and $\mathrm{SiO}_{2}$ show a high agreement or overlap and are therefore not helpful for discrimination. In this case, $\mathrm{MgO}$ and $\mathrm{FeO}$ show the highest variation in both groups (Fig. 3).

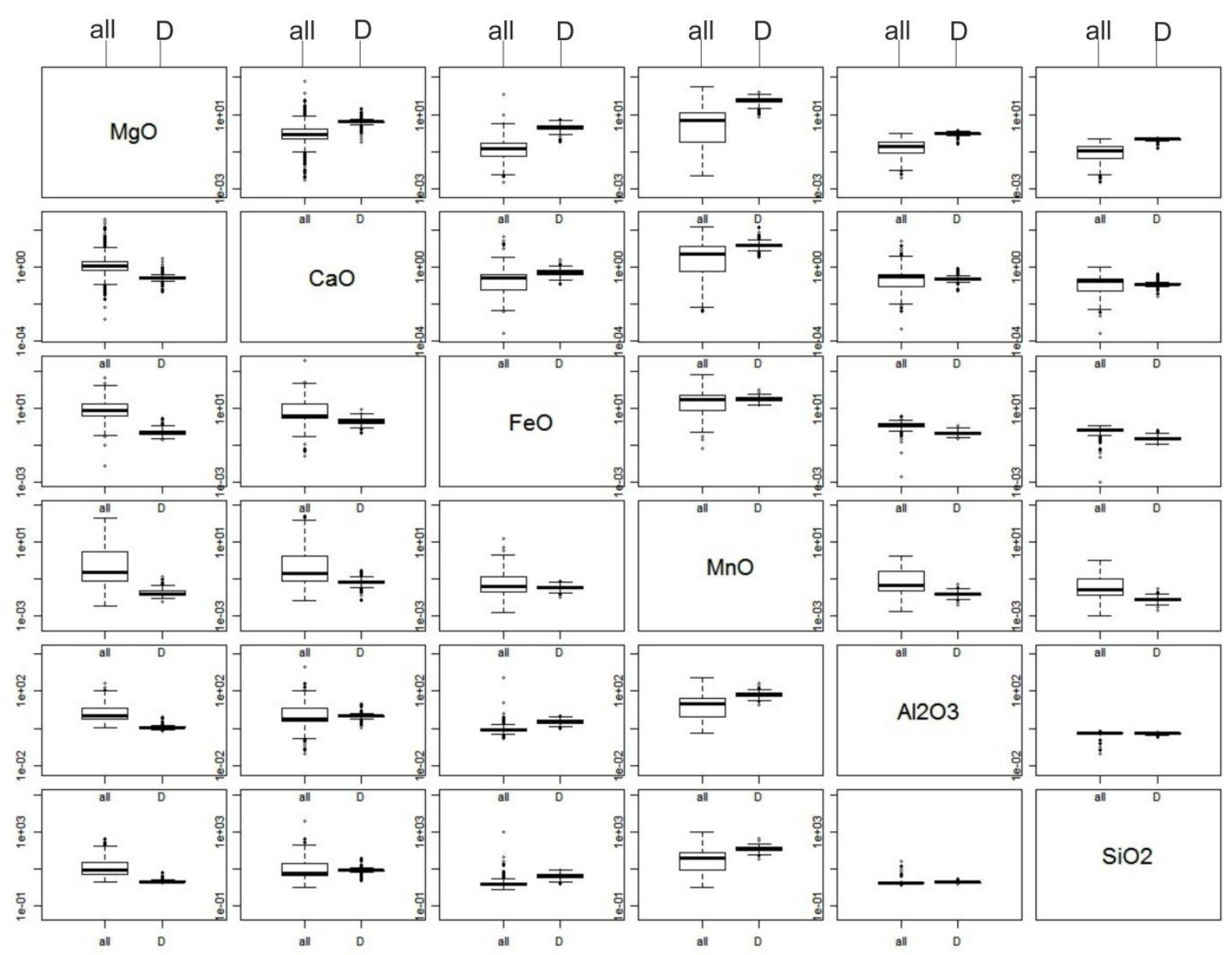

Fig. 3. Boxplots of major element variations $\left(\mathrm{SiO}_{2}, \mathrm{Al}_{2} \mathrm{O}_{3}, \mathrm{MnO}, \mathrm{FeO}, \mathrm{CaO}, \mathrm{MgO}\right)$ for the groups $\mathrm{D}$ and all.

The histogram shows the $\mathrm{Mg} / \mathrm{Fe}$ value of group all (above) and of group $\mathrm{D}$ (below) (Fig. 4). The histogram demonstrates that the ratio is different between the groups and therefore significant for discriminating garnets of group $D$ from other garnets (Fig. 4). 
$\mathrm{Mg} / \mathrm{Fe}$
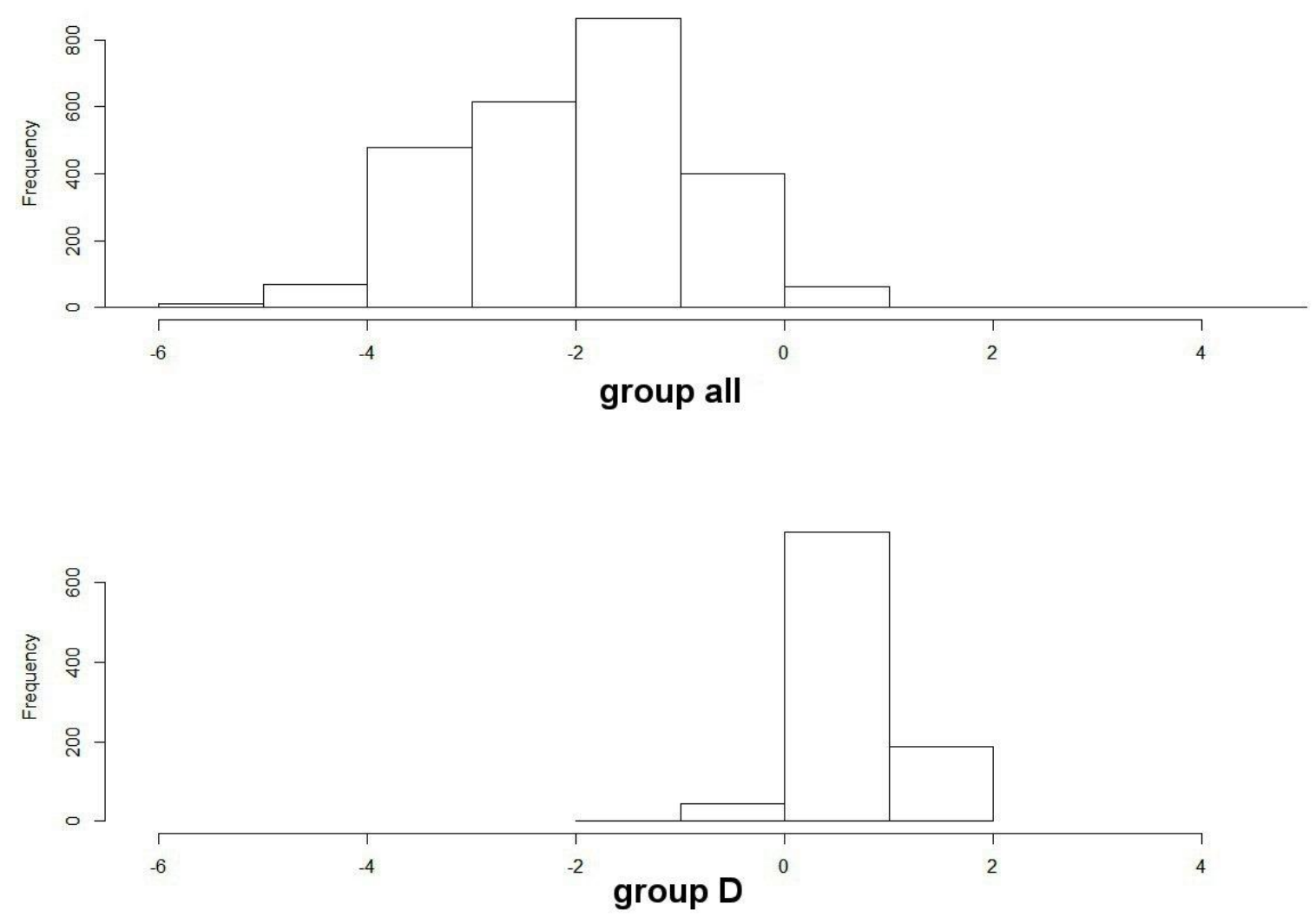

Fig. 4. Histogram showing the $\mathrm{Mg} / \mathrm{Fe}$ values of group all garnets (above) and group $\mathrm{D}$ garnets (below).

6. Discrimination of garnets from magmatic rocks (group E1) from garnets from metamorphic rocks (groups $A, B$, and $C$ )

For discrimination group $\mathrm{E} 1$ from groups $\mathrm{A}, \mathrm{B}$, and $\mathrm{C}$ (summarised as group metamorph) the major elements $\mathrm{SiO}_{2}, \mathrm{Al}_{2} \mathrm{O}_{3}, \mathrm{MgO}, \mathrm{FeO}, \mathrm{MnO}, \mathrm{CaO}$ are used. The boxplots demonstrate that $\mathrm{Al}_{2} \mathrm{O}_{3}$ and $\mathrm{FeO}$ show a high agreement or overlap and are not helpful for discrimination. In this case, $\mathrm{MnO}$ and $\mathrm{FeO}$ show the highest variation in both groups (Fig. 5). 


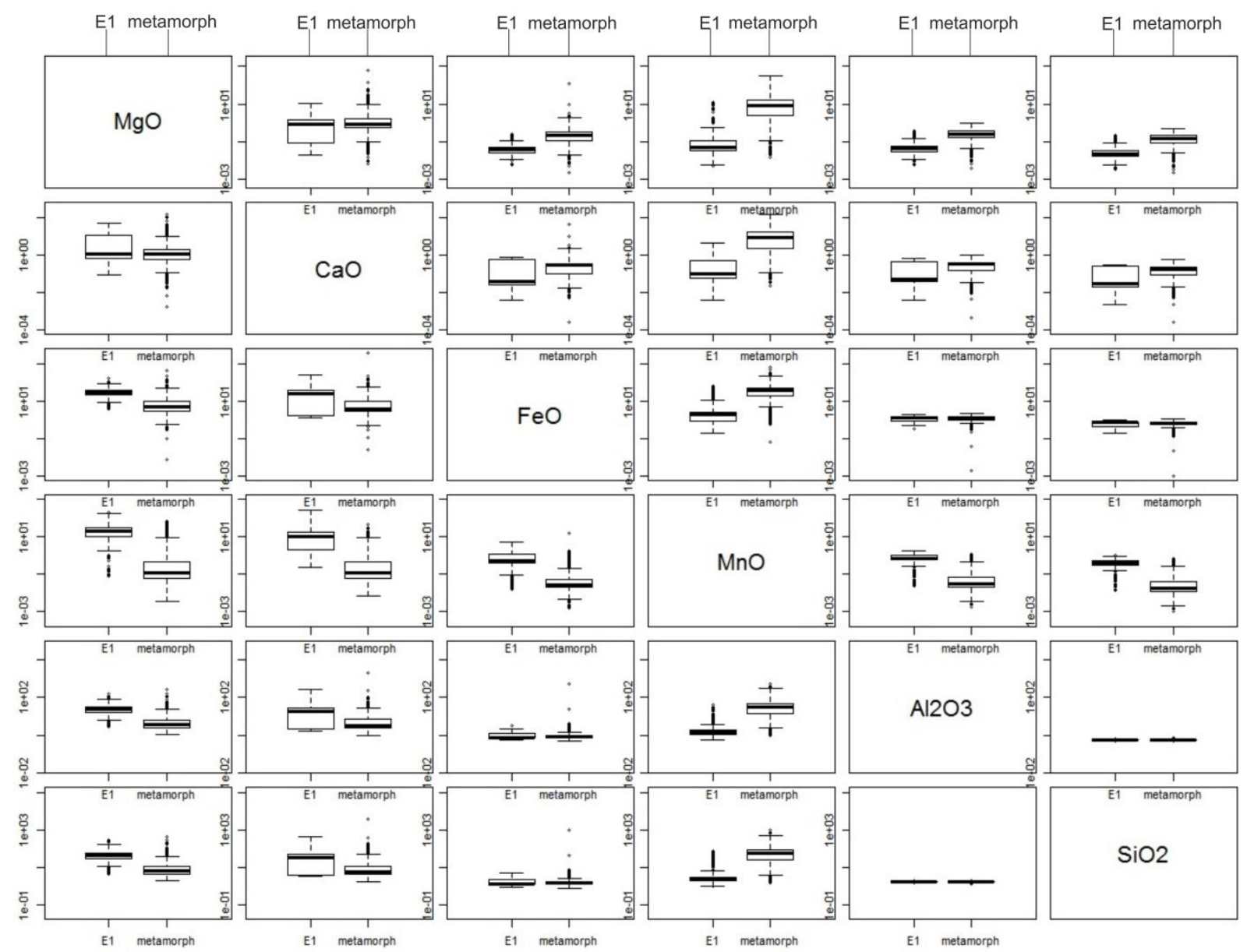

Fig. 5. Boxplots of major element variations ( $\left.\mathrm{SiO} 2, \mathrm{Al}_{2} \mathrm{O}_{3}, \mathrm{MnO}, \mathrm{FeO}, \mathrm{CaO}, \mathrm{MgO}\right)$ for the groups $\mathrm{E} 1$ and metamorph.

The histogram shows the $\mathrm{Mn} / \mathrm{Fe}$ value of group metamorph (above) and of group E1 (below) (Fig. 6). The histogram demonstrates that the ratio is different between the groups and therefore significant for discriminating garnets of group E1 from other garnets (Fig. 6). 


\section{$\mathrm{Mn} / \mathrm{Fe}$}
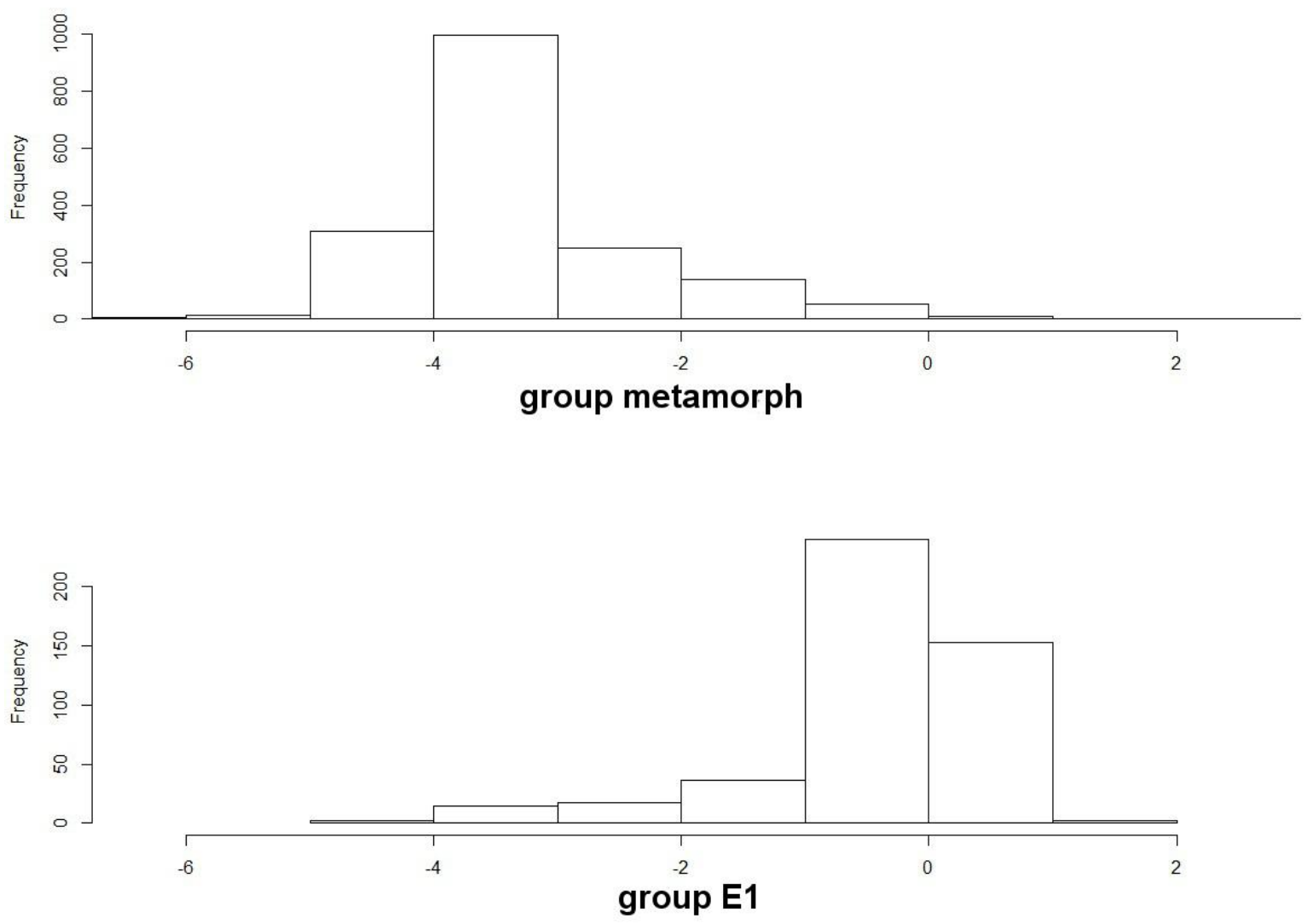

Fig. 6. Histogram showing the $\mathrm{Mn} / \mathrm{Fe}$ values of group metamorph garnets (above) and group E1 garnets (below).

\section{Discrimination of garnets from eclogites (group A), amphibolites} (group B) and granulites (group C)

For discrimination between groups $\mathrm{A}, \mathrm{B}$, and $\mathrm{C}$, the major elements $\mathrm{SiO}_{2}, \mathrm{Al}_{2} \mathrm{O}_{3}$, $\mathrm{MgO}, \mathrm{FeO}, \mathrm{MnO}, \mathrm{CaO}$ are used.

The boxplot demonstrates that most of the elements of the different groups show high overlap. The most significant variations are shown by $\mathrm{MgO}$ and $\mathrm{FeO}$ (Fig. 7). 


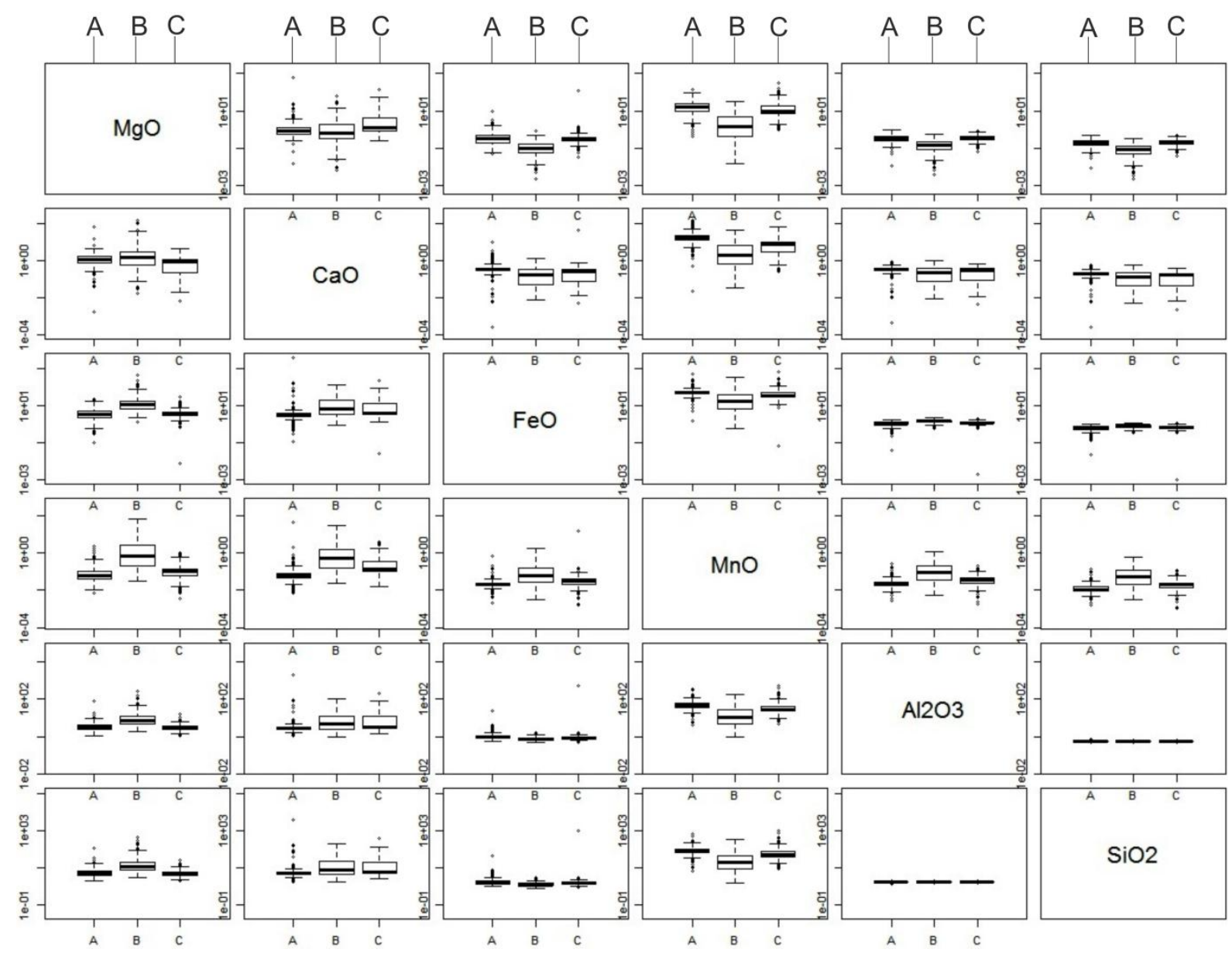

Fig. 7. Boxplots of major element variations $\left(\mathrm{SiO}_{2}, \mathrm{Al}_{2} \mathrm{O}_{3}, \mathrm{MnO}, \mathrm{FeO}, \mathrm{CaO}, \mathrm{MgO}\right)$ for the groups $\mathrm{A}, \mathrm{B}$, and $\mathrm{C}$.

The histogram shows the $\mathrm{Mg} / \mathrm{Fe}$ values of groups $\mathrm{A}, \mathrm{B}$, and $\mathrm{C}$, which show high overlap with only slight differences (Fig. 8). 
$\mathrm{Mg} / \mathrm{Fe}$
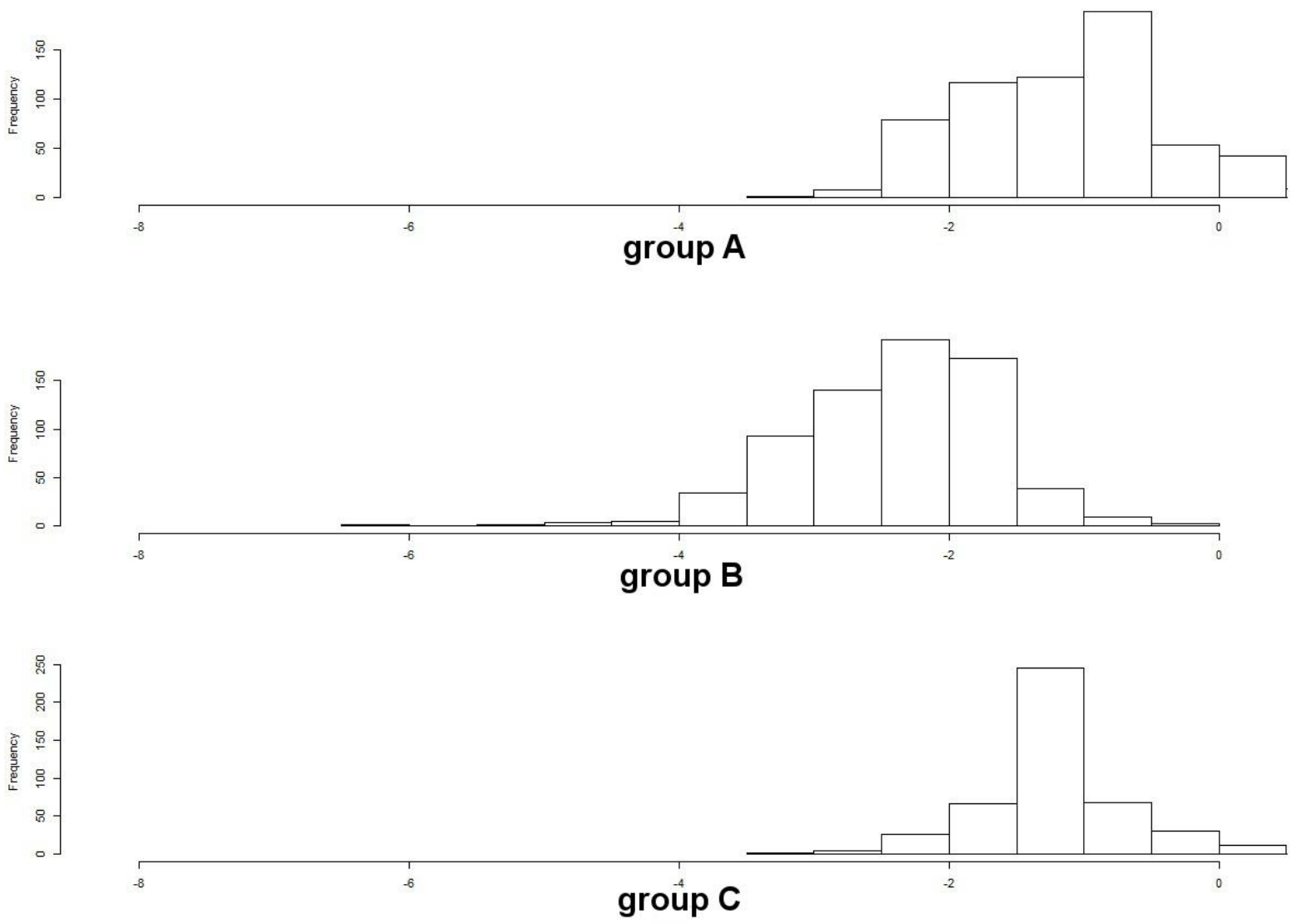

Fig. 8. Histogram showing the Mg/Fe values of groups A (above), B (middle), and C (below).

\section{Summary}

The results show the potential of discriminating between garnets from different garnet-bearing rocks. In particular, garnets from peridotites, as well as garnets from felsic plutonic rocks can be relatively clear separated from other garnet types. However, discrimination of garnets derived from different metamorphic rocks remains difficult. A general trend to higher $\mathrm{MgO}$ content with higher metamorphic grade can be observed, but a distinction is rather impossible. The results determine the limits of discrimination of different metamorphic garnets based on major elements. Therefore, it seems more appropriate to use confidence intervals and probability density distributions based on multivariate statistical analysis, than binary and ternary plots, where the discrimination fields between various garnet types are drawn as strict boundaries by solid lines. 


\section{References}

Aubrecht, R., Méres, Š., Sýkora, M., Mikus, T., 2009. Provenance of the detrital garnets and spinels from the Albian sediments of the Czorsztyn Unit (Pieniny Klippen Belt, Western Carpathians, Slovakia). Geologica Carpathica 60, 463483.

Krippner, A., Meinhold, G., Morton, A.C., von Eynatten, H., 2014. Evaluation of garnet discrimination diagrams using geochemical data derived from various host rocks. Sedimentary Geology 306, 36-52.

Mange, M.A., Morton, A.C., 2007. Geochemistry of heavy minerals. In: Mange, M.A., Wright, D.T. (Eds.), Heavy Minerals in Use. Developments in Sedimentology 58, Elsevier, Amsterdam, pp. 345-391.

van den Boogaart, K.G., Tolosana-Delgado, R., 2013. Analyzing Compositional Data with R. Springer, Berlin, Heidelberg, pp. 1-49.

Wright, W.I., 1938. The composition and occurrence of garnets. American Mineralogist 23, 436-449. 


\section{SUMMARY, CONCLUSIONS AND OUTLOOK}

\section{Summary and Conclusions}

Stream sediments preserve the geochemical record of a source region. The completeness of this record depends on the drainage system and on several processes operating during the sedimentary cycle. This $\mathrm{PhD}$ thesis investigates the application of garnet geochemistry in sedimentary provenance analysis.

Recent stream sediments and adjacent bedrocks from the Tauern window in Austria and the Western Gneiss Region in Norway have been sampled in order to study the source-to-sink relation, which have shown that garnet very well reflect the geological situation the source area. Our results underline the applicability of heavy minerals and the power of garnet geochemistry in sedimentary provenance analysis, but the results identified constraints and limits in its application, which need to be considered carefully. The discrimination of different garnet types based on major element composition is feasible, but remains difficult. Our main results and conclusions are as follows:

1. Currently available discrimination diagrams for garnet are imprecise in clearly identifying the host rock of garnet.

2. The success rates of correct and unambiguous classification being $<50 \%$ for several garnet groups. Many garnets of our large database plot outside their proposed compositional fields. Discrimination works very well for garnets derived from peridotites, felsic magmatic rocks, and also from granulite-facies sedimentary rocks.

3. Discrimination of garnets based on major elements derived from different metamorphic rocks, such as amphibolites, granulites, and eclogites remains difficult.

4. Some heavy minerals are more frequent in the fine tail of the grain-size distribution and some heavy minerals are more frequent in the coarse tail of 
the grain-size distribution, probably related to mineral grain-sizes in the source rocks.

5. Our results demonstrate, that the proportion of grossular is higher in the smaller grain-sizes, whereas the proportion of pyrope is higher in the coarser grain-size fractions, which probably results from the inheritance of grain-size from host rock to sediment. Due to the fact that grossular-rich garnet is less dense than other garnet species, a hydraulic effect is less likely than by the original finer grain-size distribution in the source rock, because less dense garnet-species are commonly found in the coarse tail of the grain-size distribution.

6. An influence of rock types, which are only rarely present in the study area, can be missed in the sediments when only a few samples are available. This is the same case with minerals, which can be missed in a specific grain-size range and therefore lead to misleading results.

7. The sample location and the studied grain-size fraction are of paramount importance in sedimentary provenance analysis, because necessary information may not be recorded and data are likely being misinterpreted.

Many studies are dealing with the application of the geochemistry of garnets, which indicates the interests in the heavy mineral and its applicability in sedimentary provenance analysis. The results of this study underline its important role in sedimentary and petrological studies and confirm the general strength and potential of garnet geochemistry for sedimentary provenance analysis. With only little amount of sample material, it is possible to get a relatively clear picture about the study area, what makes this mineral so interesting for provenance research, besides the ultrastable minerals zircon, rutile, and tourmaline and why further investigations are worthwhile. Nevertheless, an allocation of garnets to its specific host rock based on major elements remains unlikely to be resolved for the main garnet-bearing metamorphic rocks. 


\section{Outlook}

Discrimination of different garnet suites based on major elements remains difficult. A statistical approach is still in process to obtain a better discrimination of garnet groups in the future. Of course, no statistical approach can solve the problems of overlap, but a multivariate statistical model based on more than 2 or 3 variables that go beyond strict boundaries between compositional fields by providing probabilities is considered most helpful to successfully improve discrimination of a wide range of garnet-bearing source rocks. The more overlap exist between different groups (which is expected for several garnet-bearing rock types) the more necessary is a probabilistic approach that assigns to each composition a probability of belonging to one of the source-rock types.

In a further step, which is still in process, we want to establish a new classification scheme which goes beyond strict boundaries and which allows the allocation of detrital garnets to a specific host rock with the highest probability. For this the data shall be analysed by using discriminant analysis in order to gain information about compositional variations of the specific garnet groups. However, before it is possible to assign a detrital garnet to a specific rock type with the highest probability, it is needed that we test the potential of discriminating garnets from which the host rock is known. Chapter 6 presents the first ideas and first investigations for a step wise classification of garnets derived from different rock types. 


\section{APPENDIX (PROVIDED ON DVD)}

MANUSCRIPT I: Supplementary data

$>$ Appendix A

MANUSCRIPT II: Supplementary data

> Table S1: Geographic coordinates (WGS 84) of all samples (river sediments and hardrocks) from the Dorfertal, Timmeltal and Frosnitztal valleys

$>$ Table S2: Heavy Mineral Assemblages with and without opaque minerals for the grain-size fraction $63-125 \mu \mathrm{m}$

$>$ Table S3: Groups of Heavy Mineral Assemblages for the grains size fraction 63-125 $\mu \mathrm{m}$

$>$ Table S4: Groups of transparent Heavy Mineral Assemblages for the grainsize fractions 32-63 $\mu \mathrm{m}, 125-250 \mu \mathrm{m}, 250-500 \mu \mathrm{m}$ for sample A2-5, A2-8, A2-1, A2-4 from the Dorfertal valley.

$>$ Table S5: Major element composition of garnets; c: core, r: rim, z: mantle

$>$ Table S6: Content of heavy minerals from the rock formations of the Tauern window

$>$ Table S7: Thin sections of some eclogites showing grain-sizes of garnets

MANUSCRIPT III: Supplementary data

$>$ Table S1: Heavy Mineral Assemblages with and without opaque minerals for the grain-size fraction 63-125 $\mu \mathrm{m}$

> Table S2: Groups of Heavy Mineral Assemblages for the grains size fraction 63-125 $\mu \mathrm{m}$

> Table S3: Groups of transparent Heavy Mineral Assemblages for the grainsize fractions $125-250 \mu \mathrm{m}$ and $250-500 \mu \mathrm{m}$ for sample AK-N19-3

$>$ Table S4: Major element composition of garnets; c: core, $r$ : rim, m: mantle

$>$ Table S5: Proportion (\%) of the short and the long axes of garnets in the specific grain-size range from the stream sediments (AK-N20, AK-N19-4, AKN19-3 AK-N19-1) and the bedrocks (AK-N21, AK-EA).

MANUSCRIPT IV: Supplementary data

$>$ Table S1: Heavy Mineral Assemblages with and without opaque minerals

$>$ Table S2: Groups of Heavy Mineral Assemblages

$>$ Table S3: Major element composition of garnets (wt\%); c: core, r: rim, m: mantle

$>$ Table S4: Content of heavy minerals from the rock formations of Flatraket, Ulvesund, and Runde

$>$ Table S5: Thin sections of some hardrocks showing grain-sizes of garnets.

Chapter VI: Supplementary data

$>$ Appendix A 


\section{Curriculum vitae}

Persönliche Angaben

Name

Geburtsdatum

Geburtsort

Anne Krippner

23.05.1984

Herdecke

Hochschulausbildung

$2011-2015$

PhD Student an der Universität Göttingen

Titel der Dissertation:

„Application of Garnet in Sedimentary Provenance Analysis“

2011

Abschluss Master of Science

Titel der Masterarbeit:

„Provenance Analysis of Rhine River Middle

Terrace Sands between Hartheim and Cologne"

2008

Abschluss Bachelor of Science

Titel der Bachelorarbeit:

„Schwermineralanalyse unterkarbonischer

Grauwacken aus Thüringen“"

$2008-2011$

Studentische Hilfskraft am Institut für Geologie und Paläontologie der Westfälischen WilhelmsUniversität Münster

$2006-2011$

Studium der Geowissenschaften an der

Westfälischen Wilhelms- Universität in Münster

$2005-2006$

Studium der Geowissenschaften an der RuhrUniversität in Bochum

Schulausbildung

$1990-2004$

Grundschule in Witten und Gesamtschule in Witten (Westfalen)

Abschluss: Abitur

Sprachkenntnisse

Deutsch (Muttersprache)

Englisch

Spanisch (Grundlagen) 